\title{
Glacio-lacustrine sedimentation in newly discovered paleo-lakes, Westland, New Zealand
}

By

Adam Michael Thomas

\author{
A thesis \\ submitted to Victoria University of Wellington \\ in partial fulfilment of the requirements for the degree of \\ Master of Science in Geology
}

Victoria University of Wellington

2018 


\section{Abstract}

The remnant effects of Quaternary glaciation dominate the geomorphology of South Westland, New Zealand. Well-constrained glaciogenic records for the Last Glacial Maximum (LGM) ( MIS 2) show ice to have extended significant distances across the Westland piedmont, becoming tidewater calving in places. Despite clear evidence for glacial advance, landscape response to glacial retreat remains relatively poorly understood, with few described sedimentary sequences clearly recording deglaciation processes. A 240-metre thick glacio-lacustrine sedimentary sequence intercepted by drilling in the Whataroa Valley (DFDP-2) provides the first compelling evidence of proglacial lake formation in response to glacial retreat in Westland. To understand the vertical facies succession observed in this sequence, two glacio-lacustrine facies schemes and depositional models were developed. To do this, previously unmapped glacio-lacustrine sedimentary sequences in the Westland region underwent detailed sedimentological analysis to identify key glacio-lacustrine facies. In the Waitangitaona and Arahura river valleys, the presence of glacio-lacustrine sequences is also used to mark paleo-lake formation in the respective catchments.

Using the facies scheme and depositional models, together with ${ }^{14} \mathrm{C}$ chronology and sedimentological analysis, a series of conclusions are developed from the DFDP-2 sequence: 1) Deposition occurred in an over-deepened glacial trough, with the sequence consisting of a basal diamictite, overlain by a 140-metre interval of lacustrine siltstones and sandstones. 2) The lower 180-metres of sediment accumulated in $659 \pm$ 151 yrs between $16609 \pm 151$ and $15994 \pm 94$ cal. yr BP, as the depositional environment at the drill-site evolved from an ice contact to an ice distal lacustrine setting. 3) Extremely rapid sedimentation rates, as well as high lake levels allowed the preservation of glacially over-steepened bedrock slopes beneath the Whataroa Valley.

The formation of a previously unknown, $\sim 190 \mathrm{~km}^{2}$ pro-glacial lake on the Whataroa piedmont is inferred from the DFDP-2 sequence, with lake formation causing accelerated glacial retreat from the late LGM maxima. The presence of several catchments with comparable piedmont geometry suggests pro-glacial lake formation may have been a common response to glacial retreat in Westland. For a period, proglacial lakes may have been a significant transitory feature on the Westland landscape. 


\section{Acknowledgements}

Firstly, I would like to thank my supervisors Cliff Atkins and Simon Cox for their efforts over the course of my Master of Science degree. Cliff, thank you for developing my passion for Geology from first year, and for your constant enthusiasm towards this thesis. Simon, thank you for your support, pragmatism and intellectual energy. It has been a pleasure to work alongside the expertise that you both have.

Funding for my studies was received from Victoria University of Wellington as the Master's by Thesis Scholarship. Additional funding was also provided by the Geoscience Society of New Zealand, in the form of the S.J. Hastie Award. Financial support for fieldwork and sample analysis was provided by a Science Faculty Research Grant to Cliff Atkins, with additional support provided by the School of Geography, Geology and Earth Sciences. Field support was provided by GNS Science Dunedin, with laboratory facilities and equipment also provided by GNS Science and Victoria University of Wellington. Samples analysed in this thesis were collected and provided by the DFDP-2 Science Team, further acknowledged in Chapter 1.

Thank you to these institutions, and those involved with them for their support, without which this thesis could not have developed as it did.

In no particular order, acknowledgements also go to:

- Mike Hannah, for facilitating my unconventional entry into Master's Part 1, without which I may never have gone onto postgraduate study.

- Jamie Howarth, for his involvement in this project since day 1, and in particular for his role in refining the focus of this thesis.

- To my close friends, colleagues and flatmates, whom have all been involved in the Master's journey in one form or another. Thank you for dragging me away from the office, or in failing that, thank you for your patience.

- My office mates, in particular Brad, Tom, Lisa, Mel, Jack and Lucas. Thank you for the yarns, some of them even geology related.

Thank you to my family, whom this thesis is dedicated. Amy, thank you for showing me what it means to work hard. Dad, thank you for traversing Westland with me, and even carrying a rock or two. Mum, thank you for your continual patience and support, especially in the last few months. Finally, to Rachel, thank you for putting up with me for the past year, I can't wait to see where we go together. 


\section{Table of Contents}

Chapter 1 Introduction.........................................................................................1

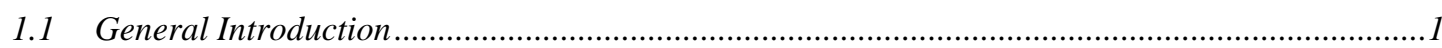

1.2 Aims

$1.3 \quad$ Study area

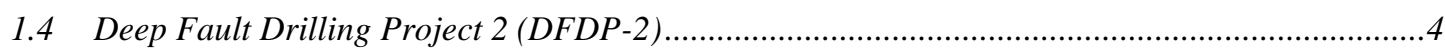

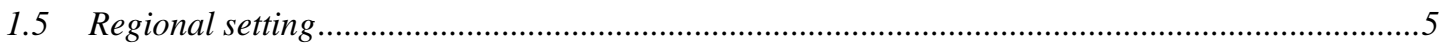

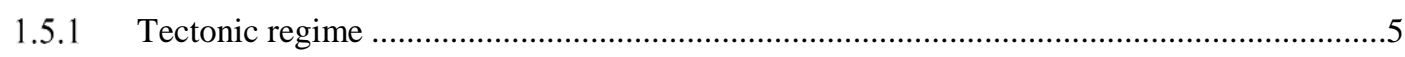

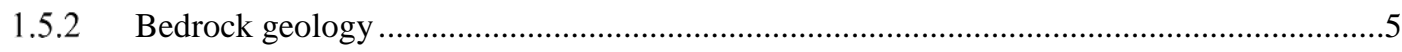

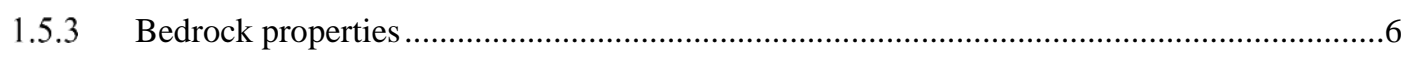

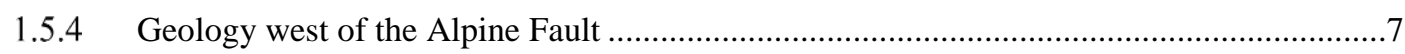

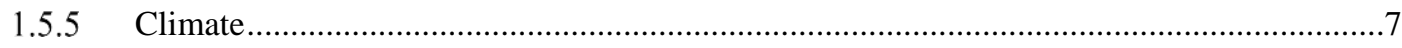

1.5.6 Quaternary development of Westland and the Southern Alps ...........................................

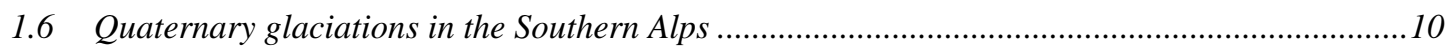

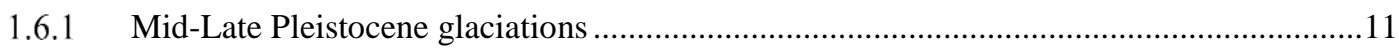

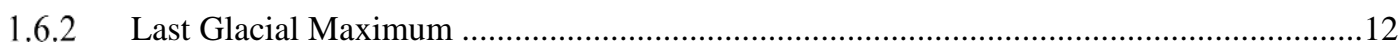

$1.7 \quad$ Last Glacial Maximum climate conditions .............................................................................15

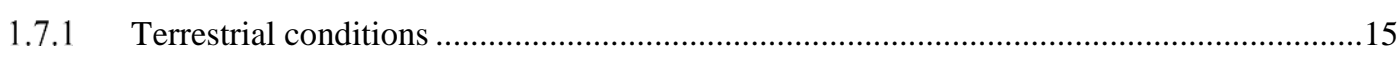

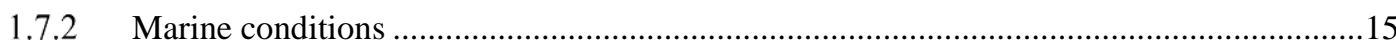

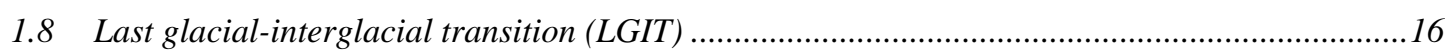

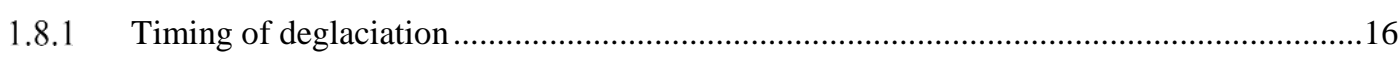

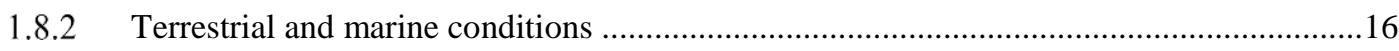

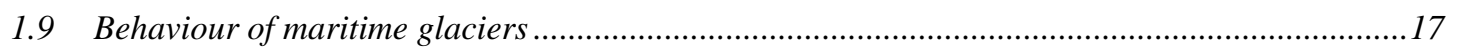

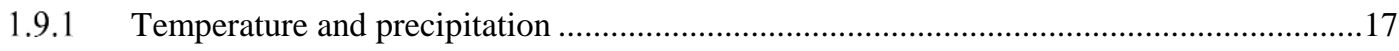

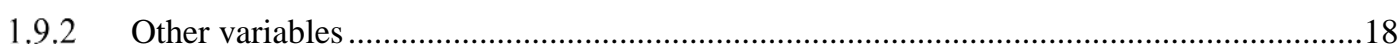

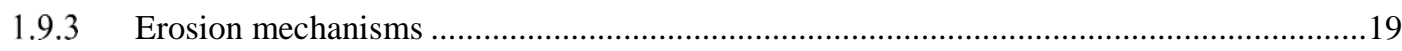

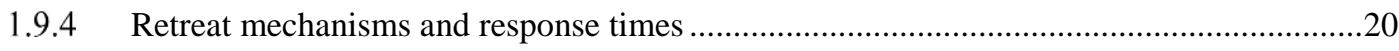

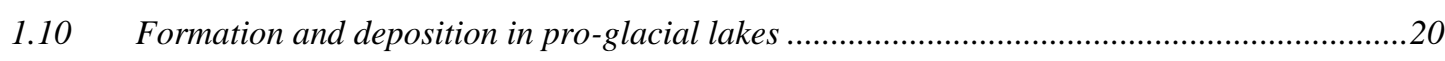

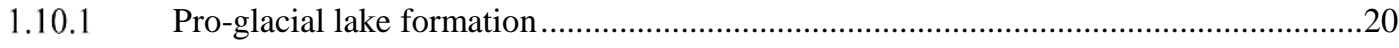

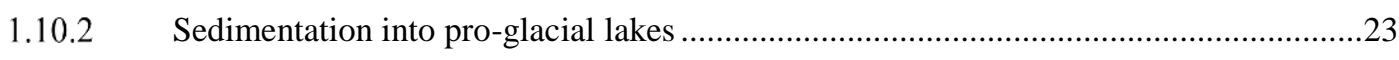

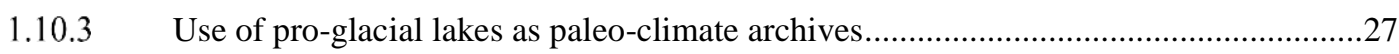

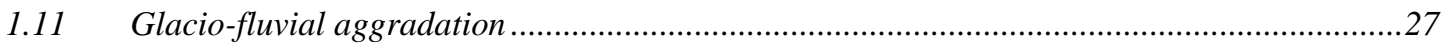

Chapter 2 Methods.................................................................................29 


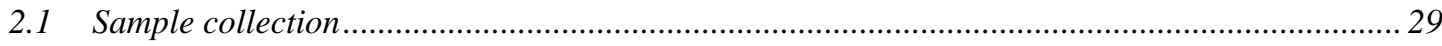

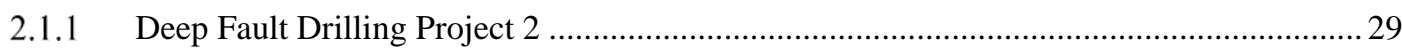

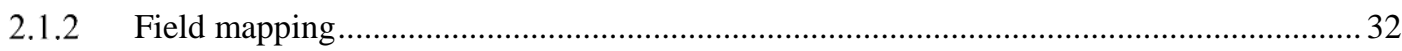

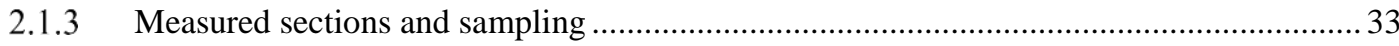

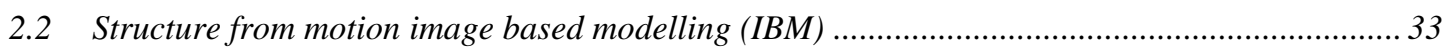

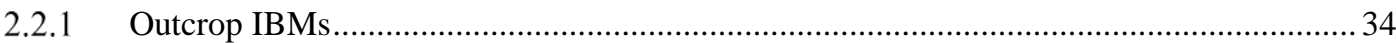

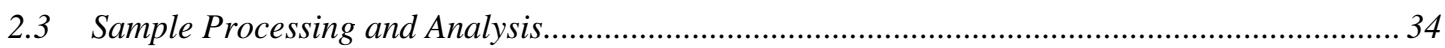

2.3.1 Grain-size analysis: Sandstone \& Mudstone samples .............................................. 34

2.3.2 Grain-size analysis: Coarse-grained samples* ........................................................ 35

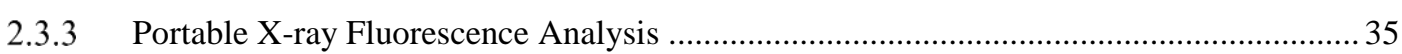

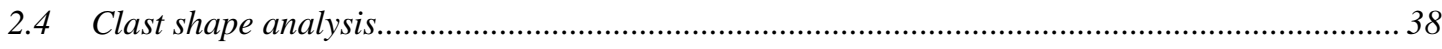

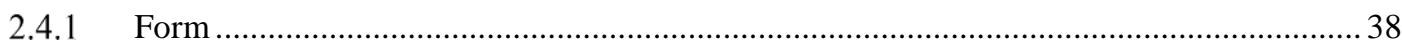

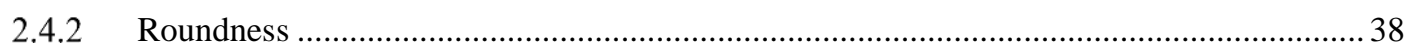

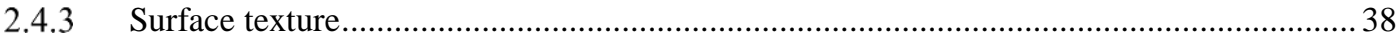

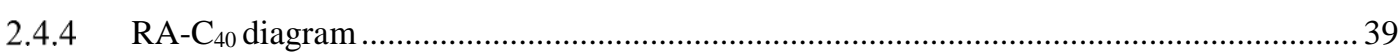

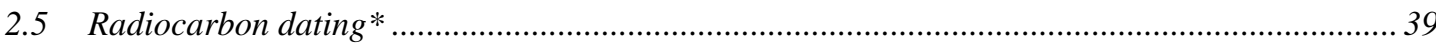

\section{Chapter 3 Outcrop and Modern analogues ........................................ 40}

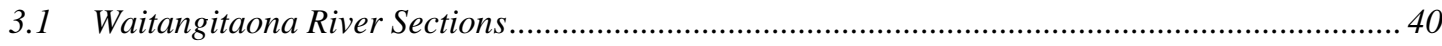

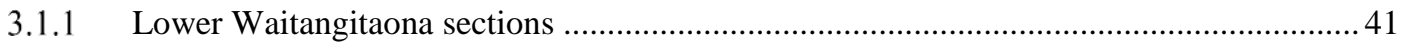

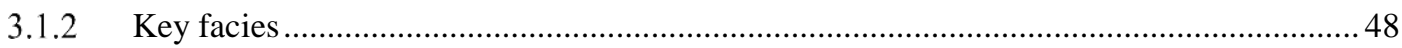

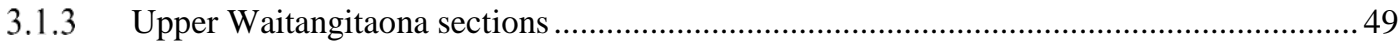

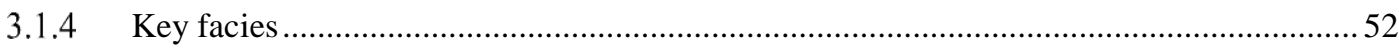

3.1.5 Facies interpretation and depositional model .............................................................. 52

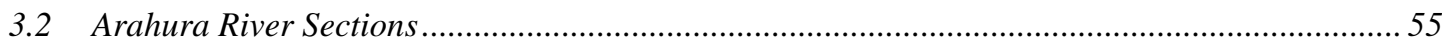

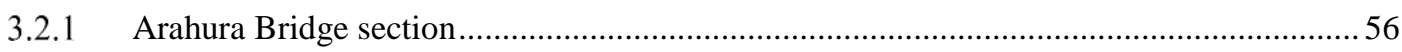

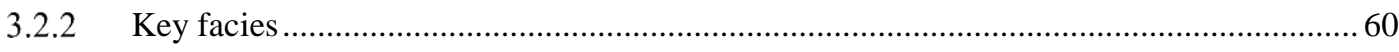

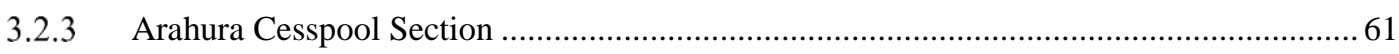

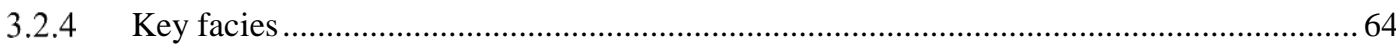

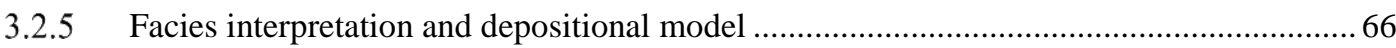

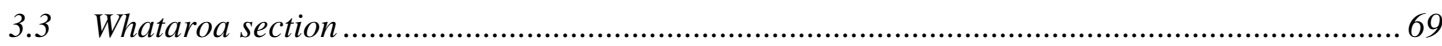

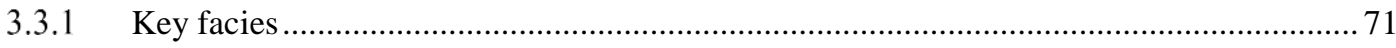

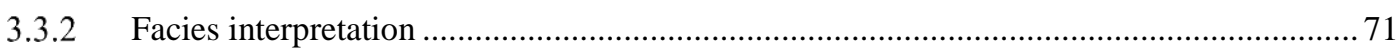

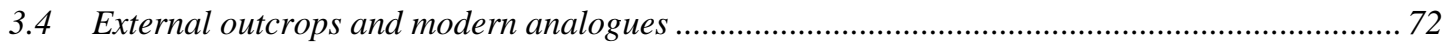

3.4.1 Ice contact Delta/Grounding line sedimentation ..................................................... 72

Chapter 4 Depositional models............................................................. 74 


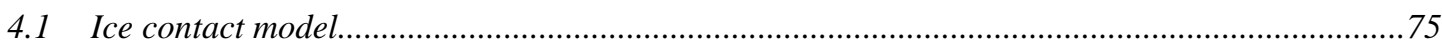

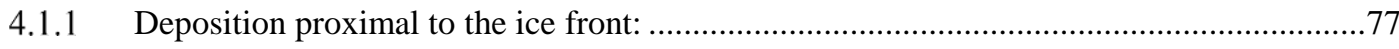

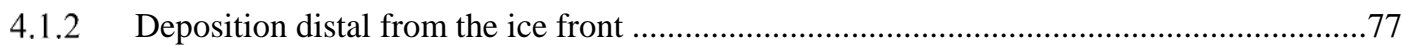

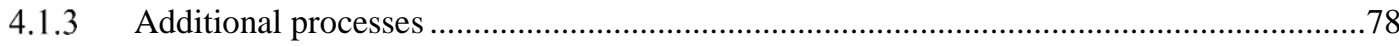

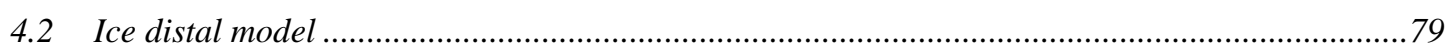

4.2.1 Deposition proximal and upstream of the shoreline.......................................................81

4.2.2 Deposition offshore from the shoreline.....................................................................82

4.3 Relationship between ice contact and ice distal models..........................................................82

\section{Chapter 5 Deep Fault Drilling Project 2..............................................84}

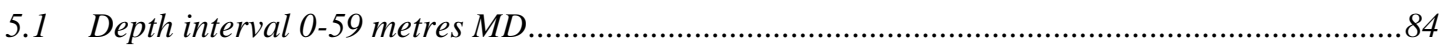

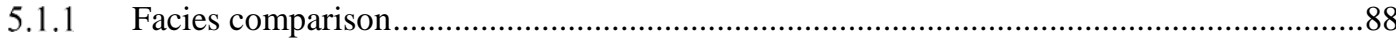

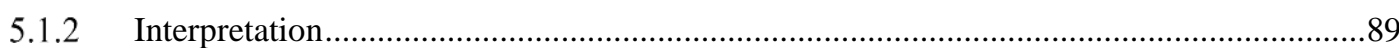

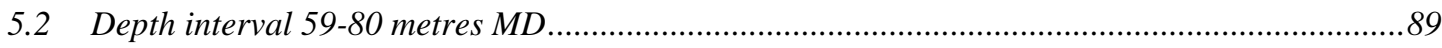

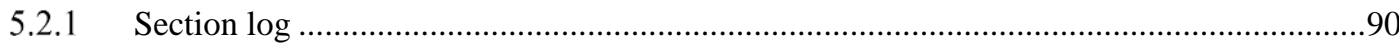

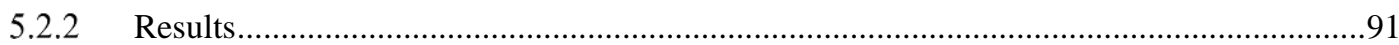

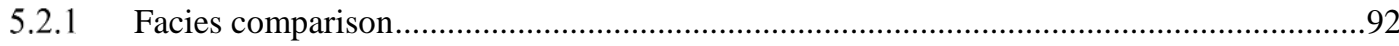

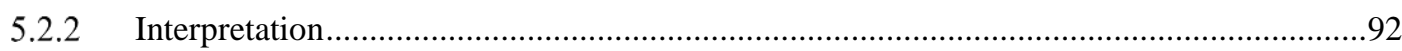

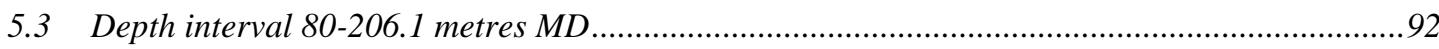

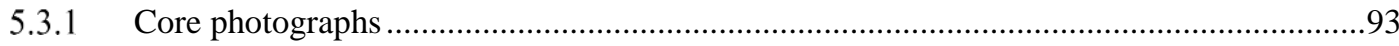

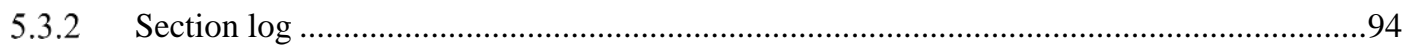

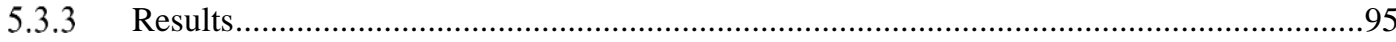

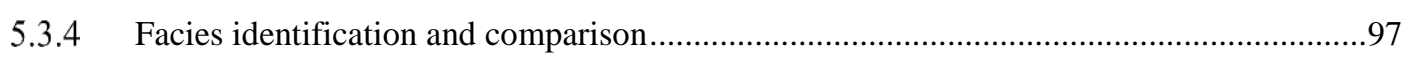

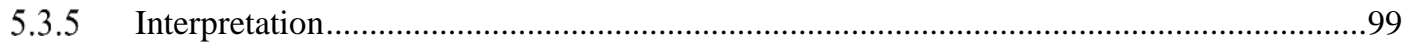

5.4 Depth interval 206.1-240 metres MD .................................................................................99

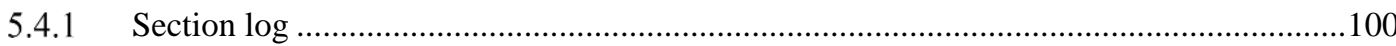

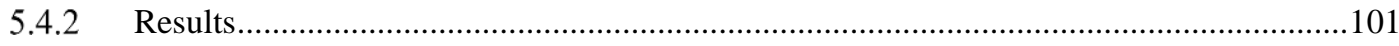

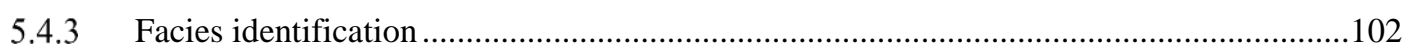

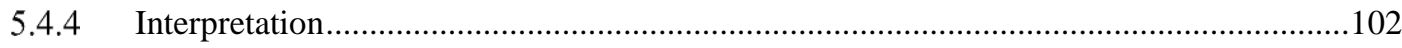

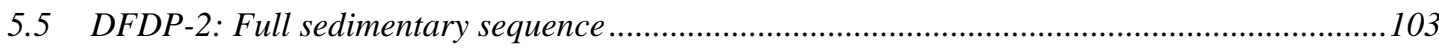

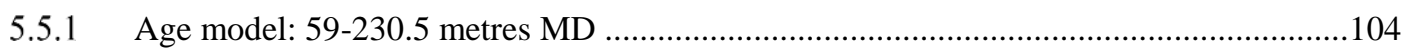

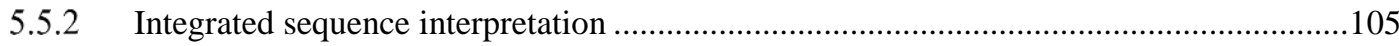

\section{Chapter 6 Discussion ..............................................................................107}

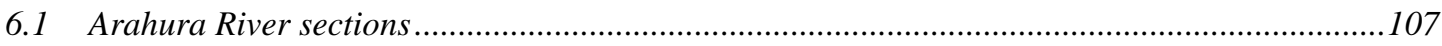

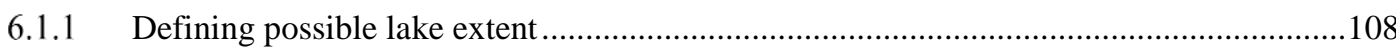

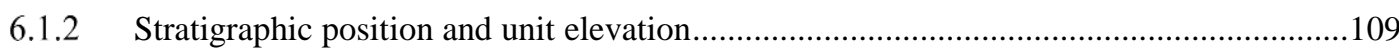




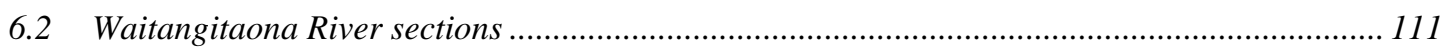

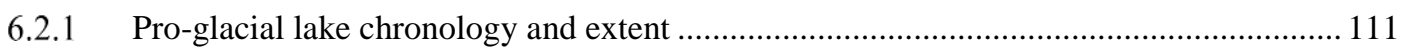

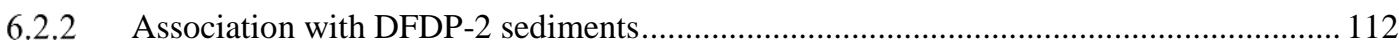

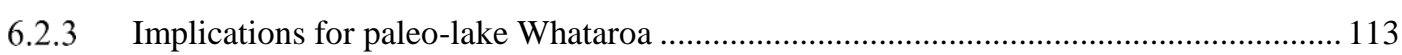

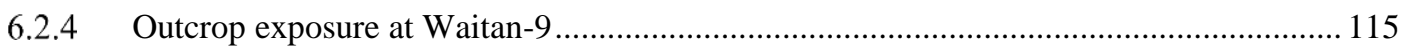

6.3 Whataroa (DFDP-2) sedimentary sequence ...................................................................... 115

6.3.1 Interpreting the DFDP-2 sedimentary sequence ................................................. 115

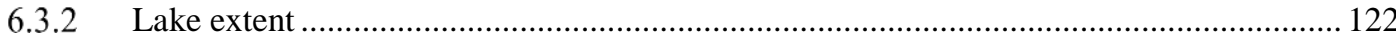

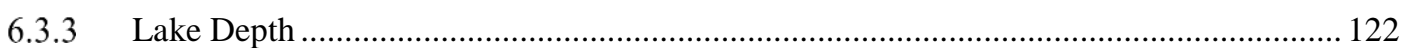

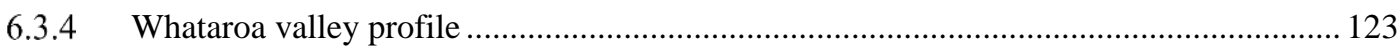

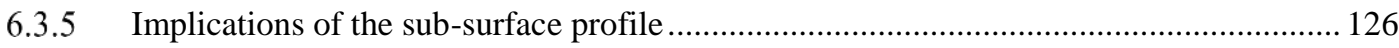

6.3.6 Sedimentation and slope support processes............................................................. 126

6.4 Equilibrium line altitude (ELA) changes during deglaciation........................................... 127

6.5 De-glaciation of the Whataroa region ................................................................................... 131

Chapter 7 Conclusions \& Future Work ............................................... 133

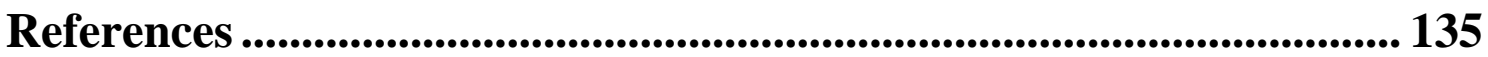

Appendix A .................................................................................................................. 142

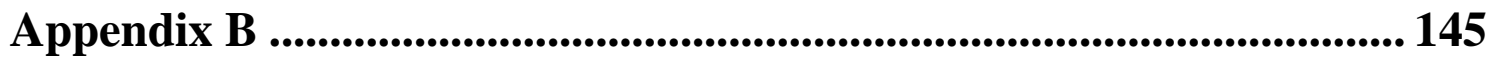




\section{List of Figures}

Figure 1.1 Wider study area (outlined in black), with key areas highlighted in red ...............................2

Figure 1.2 Whataroa and Waitangitaona field area, with key field sites identified ................................... 3

Figure 1.3 Arahura River field area, with key site identified ...............................................................

Figure 1.4 Simplified block diagram of central Southern Alps tectonic regime and geology ....................6

Figure 1.5 Modern annual precipitation over the central Southern Alps ...............................................8

Figure 1.6 Schematic of orographic rainfall due to Southern Alps ..................................................10

Figure 1.7 Stacked marine benthic oxygen isotope records with periods of glacial advance recognised by

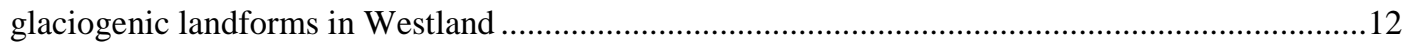

Figure 1.8 LGM ice extent in the South Island, educated by position of terminal moraines. ....................13

Figure 1.9 Otiran glacial deposits (Moana and Larrikins Fm) in the Whataroa region .............................14

Figure 1.10 Global sea level curve from the LGM to present, with the development of the Paringa fjord 17

Figure 1.11 Schematic for initiation pro-glacial lake expansion for debris cover glaciers ......................21

Figure 1.12 Location of moraine dammed lakes on the Westland piedmont.........................................22

Figure 1.13 Depositional model for ice contact glacio-lacustrine depositional environments. ................24

Figure 1.14 Depositional model for an ice contact delta depositional setting ........................................25

Figure 1.15 Depositional model for an ice distal glacio-fluvial deltaic depositional environments ...........26

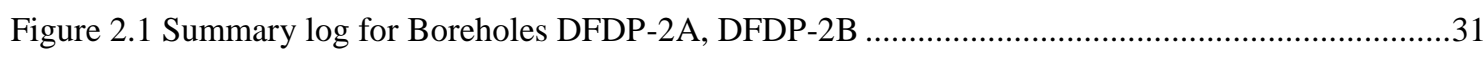

Figure 2.2 Ground control markers used for ortho-rectification ............................................................34

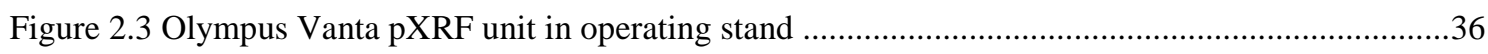

Figure 2.4 Ternary diagram plotting end-member clast shapes using a,b,c axes...................................38

Figure 3.1 Geology of the area surrounding the Waitangitaona River, with key field sites identified .......41

Figure 3.2 Laminated siltstone unit exposure at the lower Waitangitaona Sections ..............................42

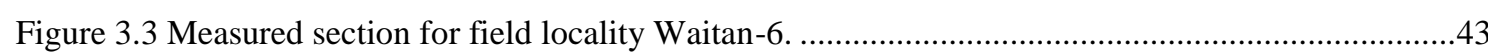

Figure 3.4 Grain-size profiles from laminated siltstone unit at the lower Waitangitaona section .............44

Figure 3.5 Field images of lonestone clasts at the lower Waitangitaona sections. ...............................45

Figure 3.6 Clast form ternary and Krumbein roundness histogram for clasts sampled from laminated

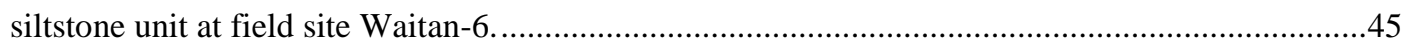

Figure 3.7 Images of lonestone clasts collected from Waitan-6 field sites...........................................46

Figure 3.8 Sandstone/Argillite and Schist bedrock in the Whataroa/Waitangitaona catchments ..............47

Figure 3.9 Annotated field images from lower Waitangitaona field sites with key facies identified .........48

Figure 3.10 Field image of the laminated siltstone unit at field site Waitan-9 .......................................50

Figure 3.11 Grain-size profile for bulk samples from field site Waitan-9 .........................................51

Figure 3.12 Facies identified from laminated siltstone unit exposed at field site Waitan-9 .....................52

Figure 3.13 Schematic depositional model for the laminated siltstone units at the lower Waitangitaona

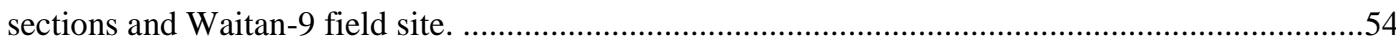

Figure 3.14 Geology of the area surrounding the Arahura River, with key field sites identified ..............55

Figure 3.15 Georeferenced ortho-photograph of the conglomerate unit at the Arahura Bridge section .....57

Figure 3.16 Measured section for the conglomerate unit at the Arahura Bridge section. ..........................58 
Figure 3.17 Clast form ternary and Krumbein roundness histogram analysis for the conglomerate unit

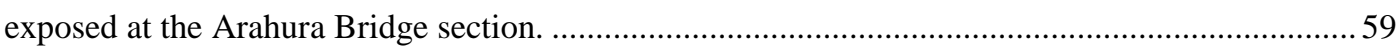

Figure 3.18 Facies identified from the conglomerate unit exposed at the Arahura Bridge section...........60

Figure 3.19 Exposure of sandy siltstone unit at the Cesspool section.............................................61

Figure 3.20 Measured section for the sandy siltstone unit exposed at the Cesspool section .....................62

Figure 3.21 Grain-size profile from sandy siltstone unit exposed at the Cesspool section. .....................63

Figure 3.22 Clast form ternary and Krumbein Roundness histogram for clasts sampled from a conglomerate bed in the sandy siltstone unit exposed at the Cesspool section.

Figure 3.23 Annotated field photo and ortho-photo of sandy siltstone unit at Cesspool section 65

Figure 3.24 Depositional model for the sandy siltstone unit and the conglomerate unit exposed at the Arahura Bridge and Cesspool sections. 68

Figure 3.25 Bedrock geology and topography surrounding the Whataroa field site 69

Figure 3.26 Ortho-photograph of the pebble-cobble conglomerate unit exposed in the Whataroa section 70 Figure 3.27 Facies identified from the pebble-cobble conglomerate exposed at the Whataroa section.....71

Figure 4.1 Ice contact depositional model, with facies annotations for the ice contact facies scheme ...... 76

Figure 4.2 Ice distal depositional model, with facies annotations for the ice distal facies scheme. ...........80

Figure 5.1 Photographs of cuttings samples collected from 0-59 metres MD, DFDP-2A ......................85

Figure 5.2 Section Log for interval 0-59 metres MD, with grain-size displayed ..................................86

Figure 5.3 Grain-size profiles of samples recovered from the upper gravels unit, 2-55 metres MD. ....... 87

Figure 5.4 Cuttings photos from interval 0-59 m MD, with facies identified ....................................89

Figure 5.5 Section log for interval 59-80 metres MD. Mean grain-size, and standard deviation shown ...90

Figure 5.6 Grain-size profiles of samples from 60-80m MD ......................................................... 91

Figure 5.7 Photographs from key sections of sediment core ........................................................ 93

Figure 5.8 Section Log for interval 80-206 metres MD, with mean grain-size and standard deviation ..... 94

Figure 5.9 Grain-size distribution of cuttings samples taken above (top) and below (bottom) of main

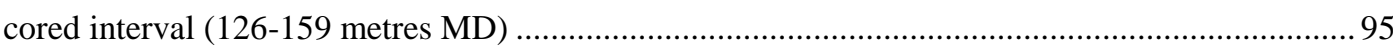

Figure 5.10 Grain-size distribution of key intervals sampled from sediment core............................... 96

Figure 5.11 Matrix grain-size profile from the basal sample of the diamictite bed, 150 metres MD...... 97

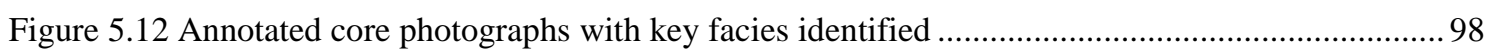

Figure 5.13 Annotated core photographs with key facies identified................................................ 99

Figure 5.14 Section log for interval 206.1-240 metres MD, with mean grain-size shown.................... 100

Figure 5.15 Grain-size profiles of clay-silt matrix from depth interval 206.1-240 metres MD .............. 101

Figure 5.16 Full section log for 0-240 metres MD, with mean grain-size and standard deviation .......... 103

Figure $5.17{ }^{14} \mathrm{C}$ age model developed for DFDP-2, 59-230.5 metres MD ........................................... 104

Figure 6.1 Inferred extent of paleo-lake Arahura, dammed by late Otiran moraine at Milltown.........109

Figure 6.2 Pro-glacial lake extent interpreted from outcrop exposures grouped as the lower Waitangitaona sections.

Figure 6.3 Inferred extent of paleo-lake Whataroa, based on position of latest Otiran moraines, remnant moraine dammed lakes, and outcrop exposures of the lower Waitangitaona sections 114 
Figure 6.4 Stratigraphy of the DFDP-2 ice contact glacio-lacustrine interval (240 to 130 metres MD), compared to the depositional model developed in Chapter 4.

Figure 6.5 Stratigraphy of the DFDP-2 glacio-lacustrine interval ( 130 to 0 metres MD), compared to the depositional model developed in Chapter 4.

Figure 6.6 Profile used to generate bedrock topographic profile through Whataroa catchment..............124

Figure 6.7 Interpreted basement profile in the Whataroa Valley, along transect marked in Figure 6.6 ...125

Figure 6.8 Model comparisons for the Whataroa catchment at ELA's of 850 and 1150 metres ..............128

Figure 6.9 Modelled ice extent in the Whataroa Valley at ELA of 1350 (5m/yr) and $1150(2 \mathrm{~m} / \mathrm{yr}) \ldots \ldots .129$

Figure 6.10 ELA vs time diagram for the Whataroa glacier. 130

\section{List of Tables}

Table 1 Integrated periods of Otiran ice advance in South Westland. .14

Table 2 Correction factors for elements of interest across varying operating modes and pXRF units ........37

Table 3 Lower Waitangitaona field sites, with outcrop thickness, lateral continuity and elevation. ..........41

Table 4 Key facies identified from the laminated siltstone unit at the lower Waitangitaona field sites. ....48

Table 5 Upper Waitangitaona field sites, with outcrop thickness, lateral continuity and base elevations. .49

Table 6 Interpretation of facies identified in the laminated siltstone units .............................................53

Table 7 Arahura Bridge section, with measured thickness, lateral continuity and base elevation..............56

Table 8 Key facies recognised in the conglomerate unit exposed at the Arahura Bridge section..............60

Table 9 Cesspool section with estimated thickness, lateral continuity and base elevation. .......................61

Table 10 Facies identified from the sandy siltstone unit exposed at the Cesspool section. ......................64

Table 11 Interpretations for facies identified in the Cesspool Unit. ....................................................66

Table 12 Interpretation of litho-facies identified in the conglomerate unit ............................................67

Table 13 Facies identified from the pebble-cobble conglomerate unit exposed in the Whataroa section. .71

Table 14 Interpretation of lithofacies identified in the pebble-cobble conglomerate unit .........................72

Table 15 Key facies identified for the ice contact delta/grounding line depositional environment. ...........73

Table 16 Facies identified in Chapter 3, with facies code primary and secondary terminology outlined...74

Table 17 Integrated facies scheme developed from outcrop for an ice contact depositional environment. 75

Table 18 Integrated facies scheme developed for an ice-distal depositional environment. .79

Table 19 Recurring beds identified from the cored interval of the laminated siltstone unit, with mean grain-size, and percent of total core length displayed 


\section{Chapter 1 Introduction}

\subsection{General Introduction}

Multiple generations of glaciogenic deposits have been recognised on the Westland piedmont, allowing precise reconstructions of glacial maxima to be made. Despite this, the geomorphic response to post-glacial retreat remains poorly understood. Sedimentary sequences recording deglaciation processes are sparse, with high erosion rates, dense vegetation and extensive surface coverage by alluvium limiting outcrop exposures.

The Deep Fault Drilling Project-2 recovered a previously unknown glacio-lacustrine sedimentary sequence, which provides new opportunities to analyse landscape response to deglaciation in Westland. To achieve this, facies schemes and depositional models are developed for glacio-lacustrine sedimentation in Westland, utilising key facies identified from previously unmapped sedimentary sequences in the region. These provide a framework to interpret the DFDP-2 sequence, allowing processes of glaciolacustrine sedimentation to be better understood, and related to the evolution of the Whataroa catchment. An improved understanding of landscape response to deglaciation will allow the glacial history of Westland to be reconstructed with greater accuracy.

\subsection{Aims}

The principal aim of this study is to understand processes and implications of glaciolacustrine sedimentation in Westland, with particular reference to the sedimentary sequence intercepted in the DFDP-2 drill holes.

Objectives to achieve this aim are:

- Identify and describe key sedimentary sequences exposed in outcrop throughout Westland.

- Develop facies schemes and depositional models for glacio-lacustrine sedimentation based on outcrop evidence and published analogues. 
- Describe the sedimentary sequence intercepted by DFDP-2A and DFDP-2B drill holes.

- Utilise the facies schemes and depositional models to interpret the DFDP-2 sedimentary sequence.

- Use these interpretations, alongside ${ }^{14} \mathrm{C}$ chronology and additional research to discuss the post-glacial evolution of the Whataroa piedmont and valley.

Additionally, an accessory chapter included in this thesis (Appendix B1) utilises DFDP2 samples to explore relationships between sediment bulk chemistry and provenance.

Findings from this chapter are related, however distinct from the aims stated above.

\subsection{Study area}

The field area for this study is the Westland region, bordered eastwards by the central Southern Alps (Kā Tiritiri-o-te-Moana) and westwards by the Tasman Sea. The majority of field research was carried out in a $\sim 50-\mathrm{km}^{2}$ area between the Whataroa and Waitangitaona river valleys (Figure 1.1, Figure 1.2). Field sites were also examined in the wider Westland region, with detailed fieldwork carried out in the Arahura river valley, Westland (Figure 1.3).

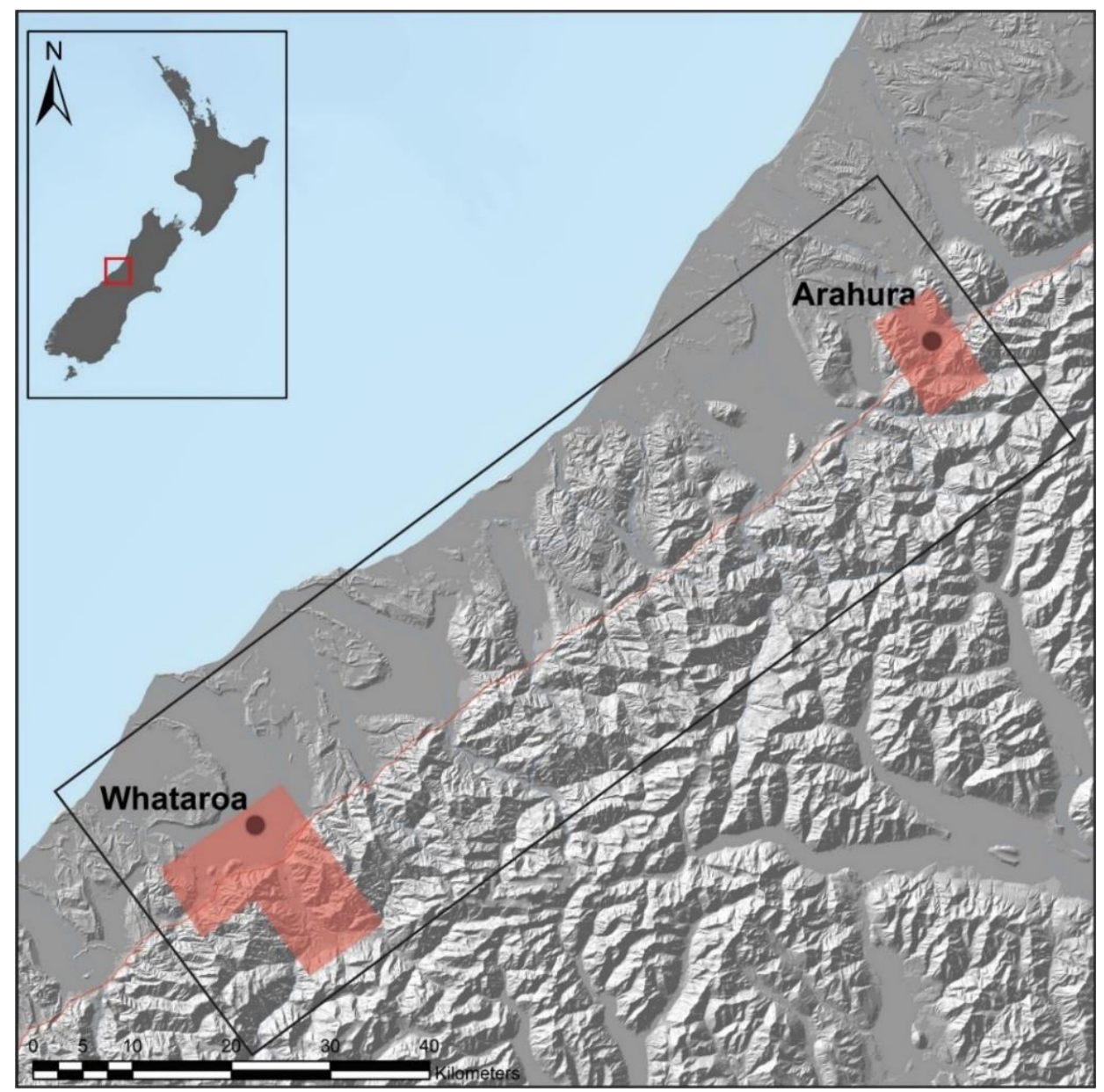

Figure 1.1 Wider study area (outlined in black), with key areas highlighted in red. Alpine Fault trace outlined in red. 


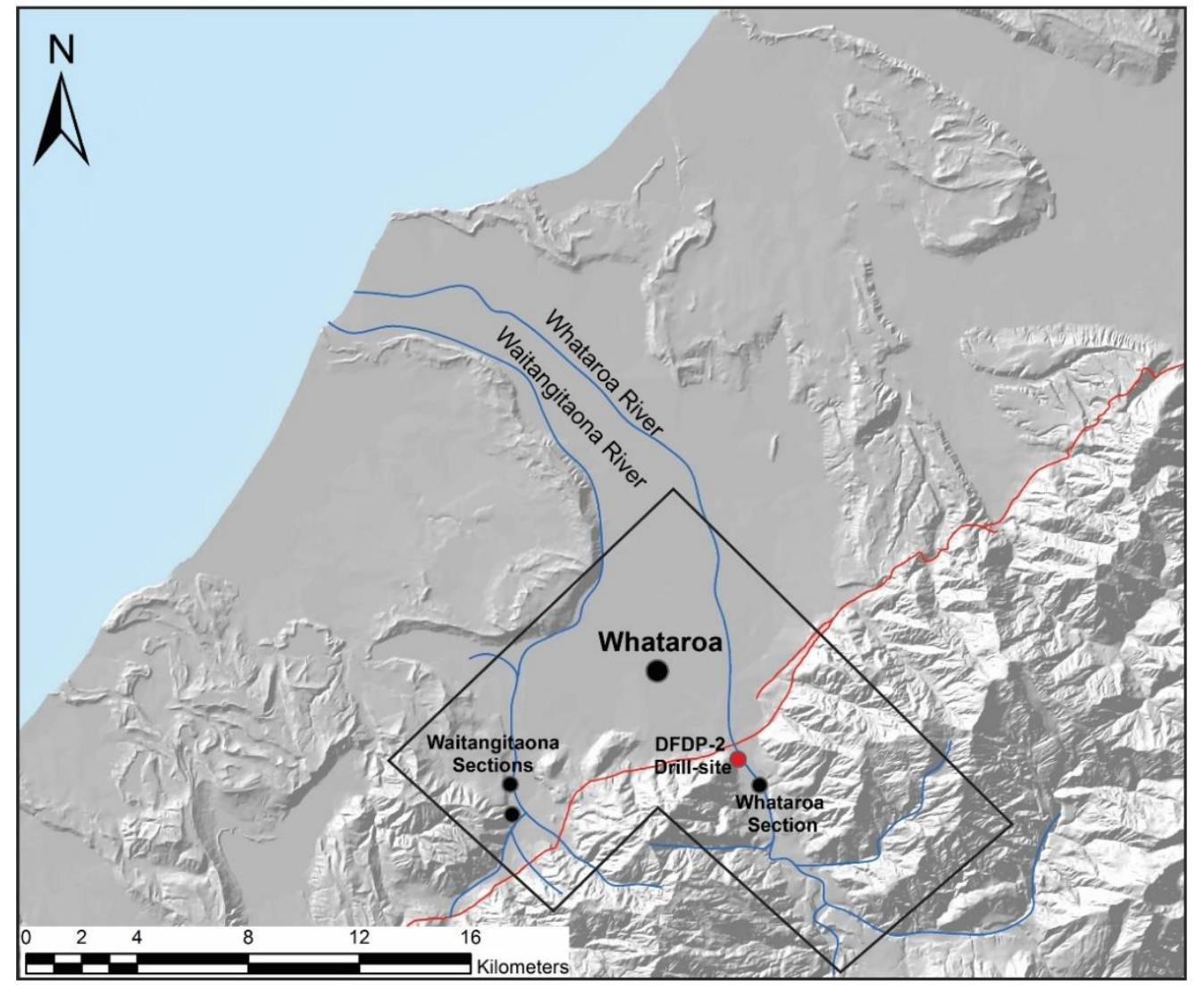

Figure 1.2 Whataroa and Waitangitaona field area, with key field sites identified. Alpine Fault surface trace in red, mapped by Cox and Barrell (2007).

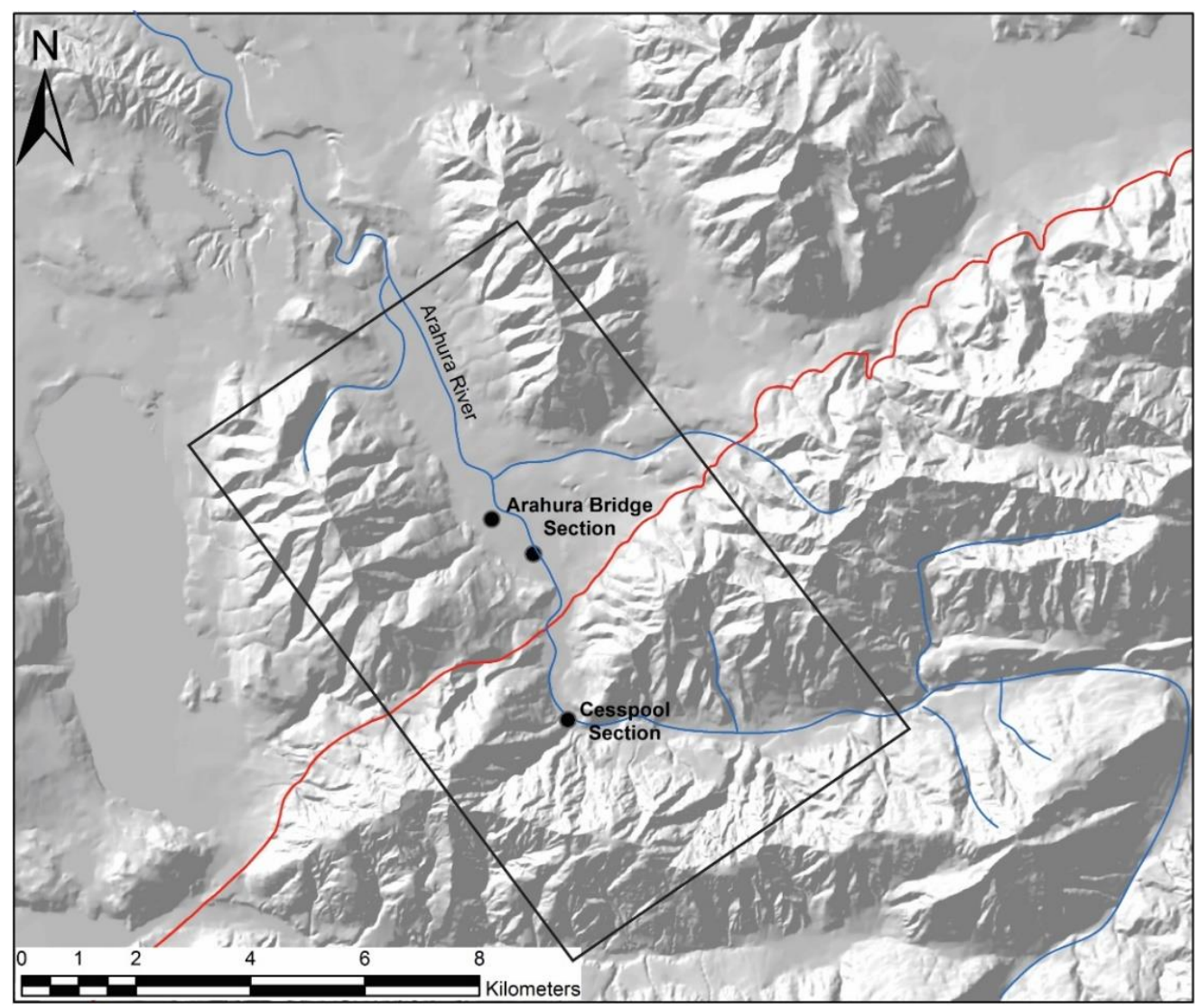

Figure 1.3 Arahura River field area, with key site identified. Alpine Fault surface trace in red, mapped by Nathan et al. (2002). 


\subsection{Deep Fault Drilling Project 2 (DFDP-2)}

The principal focus of DFDP-2 was to drill through the Alpine Fault zone at an estimated depth of $1 \mathrm{~km}$ in the Whataroa valley, South Westland (Figure 1.2). This project was funded by multiple sources, led by Rupert Sutherland, John Townend and Virginia Toy. Principal drilling contractors were Webster Drilling, Eco Drilling and Washington Drilling, supervised by Tony Kingan and Alex Pyne.

Following ground surveys and geophysical investigation, two boreholes (DFDP-2A, DFDP-2B) were drilled between August 2014 and January 2015. Borehole DFDP-2A was terminated at 212.6 metres measured depth (MD: length of drill-string from the top of the drill-rig table). Borehole DFDP-2B was terminated at 893.1 metres MD, failing to meet the target objective due to technical difficulties associated with drilling (Sutherland et al., (2015) for a full review). Geological samples recovered were predominantly drill cuttings, with some intact hard rock and sediment core. Wireline geophysical logs, fluid samples, and physical property measurements were also collected down-hole (Sutherland et al., 2015). A detailed review of drilling and collection methods for geological samples utilised in this study can be found in Section 2.1.1.

Though intercepting the Alpine Fault at depth was the primary objective of DFDP-2, an unexpectedly thick sedimentary sequence overlying regional bedrock was encountered. As the thickness of this sequence was $\sim 300$ percent greater than anticipated, it was considered scientifically interesting, though caused significant difficulty to the project. To better understand the sedimentary units being drilled, a $~ 30$-metre interval of sediment core was retrieved.

Preliminary analysis of the sedimentary sequence was carried out during drilling by the DFDP-2 Q-Team*. This analysis concluded that underlying a sequence of fluvial gravels was a 180-metre sequence of probable glacio-lacustrine sediments. The volume and characteristics of sediment intercepted warranted further analysis, providing an opportunity to investigate the depositional history of sediments in the Whataroa valley. 


\subsection{Regional setting}

Dominant in the field area are the NE-SW trending Southern Alps, a major orographic feature in the South Island. The highest elevation region of the orogen is the central Southern Alps, comprising multiple peaks greater than 3000 metres elevation and culminating in Aoraki/Mt Cook at 3,724 metres above sea level. Forming a barrier to the dominant westerly wind circulation over the South Island, the Southern Alps induces significant contrasts in precipitation between the eastern and western sides. The dual influences of elevation and precipitation allow the Southern Alps to host numerous mountain and valley glaciers.

\subsubsection{Tectonic regime}

The Southern Alps represent the product of continental collision between the Australian and Pacific Plates. Transpression along the plate boundary has driven the formation of the Southern Alps, and more broadly the South Island landmass (Cox and Sutherland, 2007). Displacement along the Pacific-Australian plate boundary is dominantly accommodated by motion along the Alpine Fault (Sutherland, 1999), a major oblique slip fault which delineates the western margin of the Southern Alps.

Motion along the Alpine Fault is estimated to be 50-80 percent dextral strike-slip (Wallace et al., 2007), with offset late Quaternary deposits constraining the strike-slip displacement rate to $27 \pm 2 \mathrm{~mm} / \mathrm{yr}$ through the central Southern Alps region (Norris and Cooper, 2001). Reverse dip slip rates vary significantly along the fault, however are highest in the central Southern Alps with estimates in the order of $12 \mathrm{~mm} / \mathrm{yr}$ (Norris and Cooper, 2001). In the Whataroa Region, uplift rates are shown to be up to 9-10 mm/yr. (Little et al., 2005, Herman et al., 2009, Batt et al., 2000).

\subsubsection{Bedrock geology}

On the Alpine Fault hanging wall, a $\sim 300 \mathrm{~km}$ long belt of mid-upper crustal rocks are exposed, with metamorphic grade varying from amphibolite facies adjacent to the Alpine Fault, through greenschist and prehnite-pumpellyite facies toward the southeast (Figure 1.4) (Little et al., 2005, Cox et al., 2012). Regionally, metamorphic grades can be recognised by the presence or absence of key mineral assemblages. Biotite to amphibolite grade schists exposed along the orogen are referred to as Alpine Schist, based on the terminology introduced by Wellman et al. (1952). 
Alpine Schists are included as part of the Haast Schist Group, associated with schist exposures in the Otago Region (Mortimer et al., 2014). Mineral growth in the Otago Schist is attributed to Jurassic-early Cretaceous metamorphism, however in the Alpine Schist there is evidence for late Cretaceous metamorphic growth (Little et al., 2002). There is also evidence for peak metamorphic temperatures in the Alpine Schist being reached during the late Cenozoic (Vry et al., 2004).

Further eastwards from the Alpine Fault, Pacific plate rocks are dominated by the Torlesse Supergroup (Mortimer et al., 2014) consisting Carboniferous-Cretaceous quartzofelspathic meta-sedimentary rocks. Low grade regional metamorphism of the Torlesse Supergroup occurred during the Jurassic-Cretaceous, with overprinting metamorphism occurring during the Neogene (Mortimer, 2000, Cooper and Ireland, 2013).

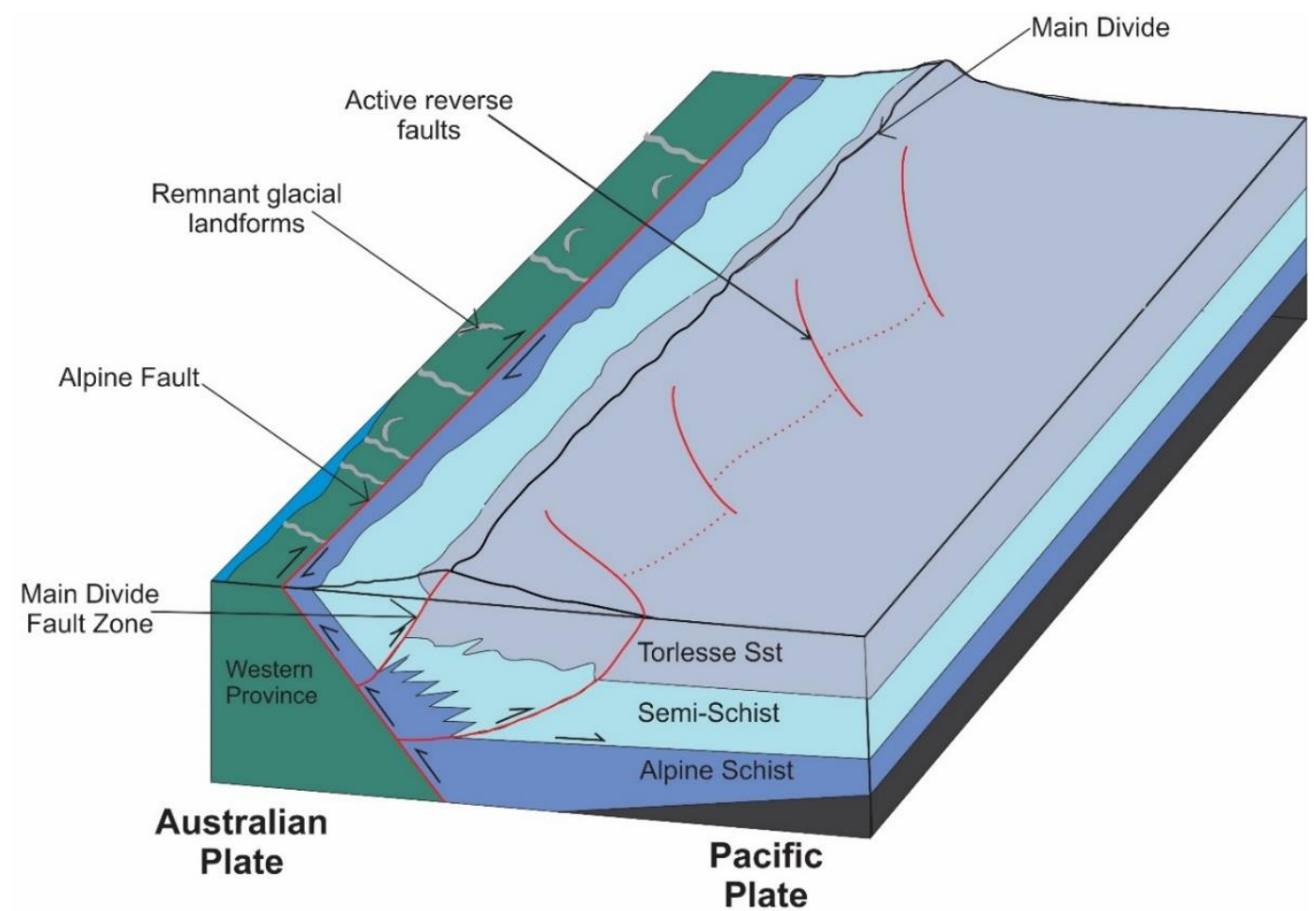

Figure 1.4 Simplified block diagram of central Southern Alps tectonic regime and geology. Modified from Cox and Sutherland (2007).

\subsubsection{Bedrock properties}

A detailed evaluation of bedrock peak metamorphic temperature in the western Southern Alps was carried out by Beyssac et al. (2016) using Raman spectroscopy of carbonaceous material as a geo-thermometer. In the Whataroa region, spatial variance in peak metamorphic temperature is significant, decreasing from $\sim 640{ }^{\circ} \mathrm{C}$ in amphibolite facies rocks proximal to the Alpine Fault, to $>330{ }^{\circ} \mathrm{C}$ in prehnite-pumpelyite facies 
rocks proximal to the Main Divide (Beyssac et al., 2016). The pattern of decreasing peak metamorphic temperature with distance up the hanging wall is displayed across the central Southern Alps, consistent with changes in metamorphic facies.

Following the subdivision outlined by Nibourel et al. (2015), meta-sedimentary rocks exposed on the Alpine Fault hanging wall can be distinguished into 3 textural categories, based on the degree of metamorphism, as well as the appearance of index minerals. Simplified textural categories of schist, semi-schist and sandstone are shown to be effective both to reflect the bedrock physical properties as well as metamorphic facies (Nibourel et al., 2015, Turnbull et al., 2001, Sutherland et al., 2015).

Variance in bedrock metamorphic grade that is present in West Coast catchments promotes the use of petrological methods to study the provenance of sediments eroded off such bedrock. Most recently, Raman spectroscopy of carbonaceous material has been shown as an effective high-resolution provenance tool for Westland sediments (Nibourel et al., 2015 , Herman et al., 2015).

\subsubsection{Geology west of the Alpine Fault}

Westwards of the mountain front, the Westland piedmont assumes a low angle morphology, varying in width from 10-20 kilometres to meet the Tasman Sea at the northwest margin. Quaternary deposits dominate this region, consisting mid to late Pleistocene moraines, outwash plains and alluvial fans (Cox \& Barrell, 2007). In lowland areas, localised depressions are occupied by ponds, tarns, lakes and swamplands, many of which are utilised for palynology based paleo-climate reconstructions (Moar and Suggate, 1996, Vandergoes et al., 2013).

Sparse meta-sedimentary and plutonic basement rocks, broadly grouped under the Western Province are locally exposed west of the Alpine Fault (Cox and Barrell, 2007). Representing a relict fragment of Gondwana, exposed Western Province basement is lithologically variable, typically outcropping as bedrock highs mantled by Quaternary deposits.

\subsubsection{Climate}

The climate of Westland is dominated by the orographic effect of the Southern Alps mountain chain. Varying from 2 to near 4 kilometres in elevation in the central region, the Southern Alps acts to perturb the prevailing moisture laden westerly winds 
(Henderson and Thompson, 1999). Orographic rainfall produces an extreme contrast in precipitation between the western and eastern sides of the ranges, with western regions experiencing in excess of 10 metres of precipitation annually (Figure 1.5) (Griffiths and McSaveney, 1983, Henderson and Thompson, 1999).

The climate of the Westland piedmont is temperate, with a mean annual temperature of $\sim 12{ }^{\circ} \mathrm{C}$ and a temperature change with altitude of $4.7^{\circ} \mathrm{C} /$ kilometre (Stuart, 2009).

Present equilibrium line altitudes (ELA) are estimated at $\sim 1850$ metres for Franz Josef Glacier (Kā Roimata o Hine Hukatere) and Fox Glacier (Te Moeka o Tuawe) (Appleby et al., 2010). Both glaciers have relatively large accumulation zones above 2000 metres, characterised by a large gently sloping neve and long glacier tongues. In catchments with smaller accumulation zones, glaciers typically display a cirque morphology, and do not extend significant distances down the catchment (Chinn et al., 2005).

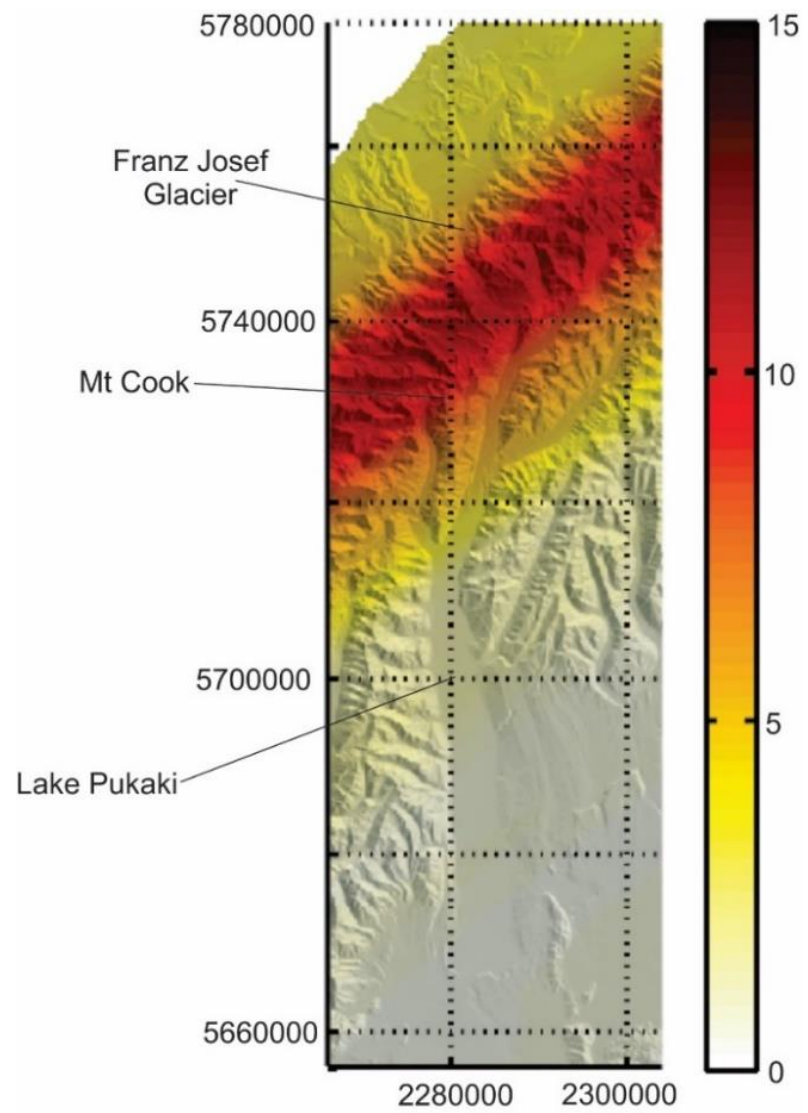

Figure 1.5 Modern annual precipitation over the central Southern Alps, interpolated from rain gauge measurements. Modified from McKinnon (2011) after Stuart (2011).

\subsubsection{Quaternary development of Westland and the Southern Alps}

The Quaternary development of the Westland and central Southern Alps landscape is affected by the influences of tectonism, climatic change and active erosion (Cox and Sutherland, 2007). 
Offset late Quaternary landforms show Pliocene to Recent deformation occurring along the Alpine Fault, with dip slip rates of $8-10 \mathrm{~mm} / \mathrm{yr}$ or greater in the central Southern Alps region (Norris and Cooper, 2001). Direct evidence for Quaternary deformation in the central Southern Alps is sparse, with little geomorphic evidence for offset along mapped faults. This is attributed to the rapidly evolving Southern Alps landscape, with high erosion rates and Quaternary glaciation removing fault offset features from the landscape (Cox et al., 2012).

Contemporary erosion in the central Southern Alps appears to correlate with precipitation, with erosion dominant west of the main drainage divide (Hicks et al., 1996). Estimates of erosion rates in West Coast catchments typically fall between 5-11 $\mathrm{mm} / \mathrm{yr}$, based on calculations from stream discharge rates (Griffiths, 1979). Land sliding is shown to be the process dominating contemporary erosion, with denudation rates averaged at $9 \mathrm{~mm} \pm 4 \mathrm{~mm} / \mathrm{yr}$ across large West Coast catchments (Hovius et al., 1997, Korup et al., 2010).

On geological timescales, erosion rates can be quantified using cosmogenic nuclide and thermochronometric methods. Optically stimulated luminescence thermochronometry applied by Herman et al. (2010) shows remarkably uniform exhumation rates in the central Southern Alps region on 100 kyr timescales, observed to be consistent with modern denudation rates. Throughout the Quaternary, a number of glacial advances are recognised in the Southern Alps, where large valley glaciers extended across the Westland piedmont, in cases becoming tidewater calving (Barrell, 2011). The expansion of alpine glaciers during glacial periods is typically cited as driving higher erosion rates than fluvial incision and hillslope erosion during interglacial periods. This hypothesis is supported to an extent by the geometry of previously glaciated West Coast catchments, many of which display a characteristic glacial "U” shape (Whitehouse, 1986).

The influences of fluvial and glacial erosion in forming the present morphology of the central Southern Alps was examined by Adams (1980), who proposed that while glaciers deepen and widen valleys, compared to fluvial erosion they do little to erode material from valley slopes. The findings of Herman et al. (2010) support this, in suggesting that erosion rates in the central Southern Alps may remain relatively similar through glacial-inter-glacial cycles, as opposed to being dominated by erosion during glacial periods. 


\subsection{Quaternary glaciations in the Southern Alps}

High accumulation rates, coupled with high elevation allows temperate glaciers to form in the Southern Alps (Figure 1.6). Presently, the South Island hosts >3000 glaciers varying significantly in both size and morphology (Chinn, 2001). Glaciers hosted in the heavily dissected topography west of the Main Divide (termed West Coast glaciers) tend to be highly active, with steep bed profiles and high rates of mass turnover (Chinn, 2001, Anderson and Mackintosh, 2012).
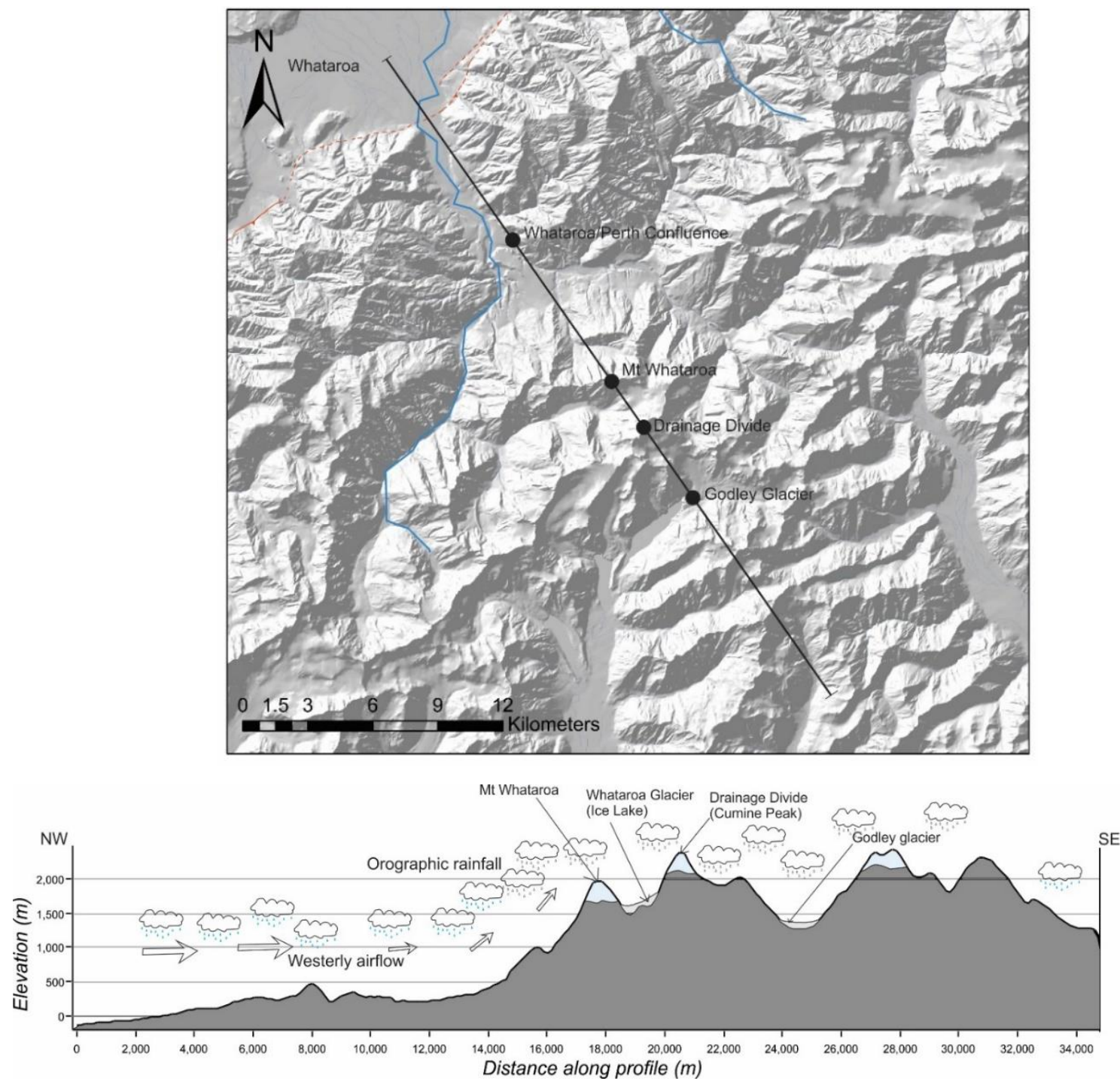

Figure 1.6 Schematic of orographic rainfall due to Southern Alps. Topography generated from LINZ 50m contours in ArcGIS, along profile line displayed in upper figure. Note asymmetry east and west of drainage divide (Vertical exaggeration).

West Coast glaciers are extremely sensitive to climatic changes which lead to variance in temperature and/or rainfall, responding to both local, as well as global climatic fluctuations (Anderson and Mackintosh, 2006, Shulmeister et al., 2004). The presence of multiple generations of glaciogenic landforms across the Westland piedmont, first 
recognised by Julius Haast and Dr Ferdinand von Hochstetter in 1858 (Gage, 1985), show irrefutable evidence that Southern Alps glaciers have responded to glacialinterglacial cycles in the past.

In building a database of Central South Island Glacial Geomorphology (CSIGG), Barrell et al. (2013) summarised Quaternary glaciations in the Southern Alps. Glaciogenic records are one of the few terrestrial climate proxies from the Westland region that extend prior to the Last Glacial Maximum (Callard, 2011), therefore are useful as extended paleoclimate archives. Landforms preserved in Westland are used for dating and reconstructing glacial maxima, and can be temporally related to the response of glaciers east of the Main Divide (Barrell, 2011). The well-studied, but fragmentary glaciogenic landform record of the Westland region is discussed in detail below:

\subsubsection{Mid-Late Pleistocene glaciations}

The location of terminal and lateral moraine sequences show mid-late Pleistocene glaciers to be considerably larger than present, with mountain glaciers coalescing to extend considerable distances across the Westland piedmont (Barrell, 2011).

Mid-Pleistocene glacial advances are recognised for Marine Isotope Stage (MIS) 10, 8 and 6 (Figure 1.7) in fragmentary moraine records north of 4330’S (Suggate, 1990), many of which have been laterally offset by Alpine Fault motion. Utilising cosmogenic nuclide exposure dating, Thackray et al. (2009) provide evidence for MIS 4 ice expansion in the northwest Nelson region, supported by moraine exposures in Westland which are inferred to be MIS 4 (Cox and Barrell, 2007).

Further south, cosmogenic exposure dating on lateral moraines in the Cascade valley is used to infer two periods of glaciation at $\sim 58 \mathrm{ka}$ and $\sim 79 \mathrm{ka}$ (Sutherland et al., 2007). Despite limitations of the exposure dating in both studies, the conclusions of both Thackray et al. (2009) and Sutherland et al. (2007) provide evidence for MIS 4 glacial advance in Westland. 


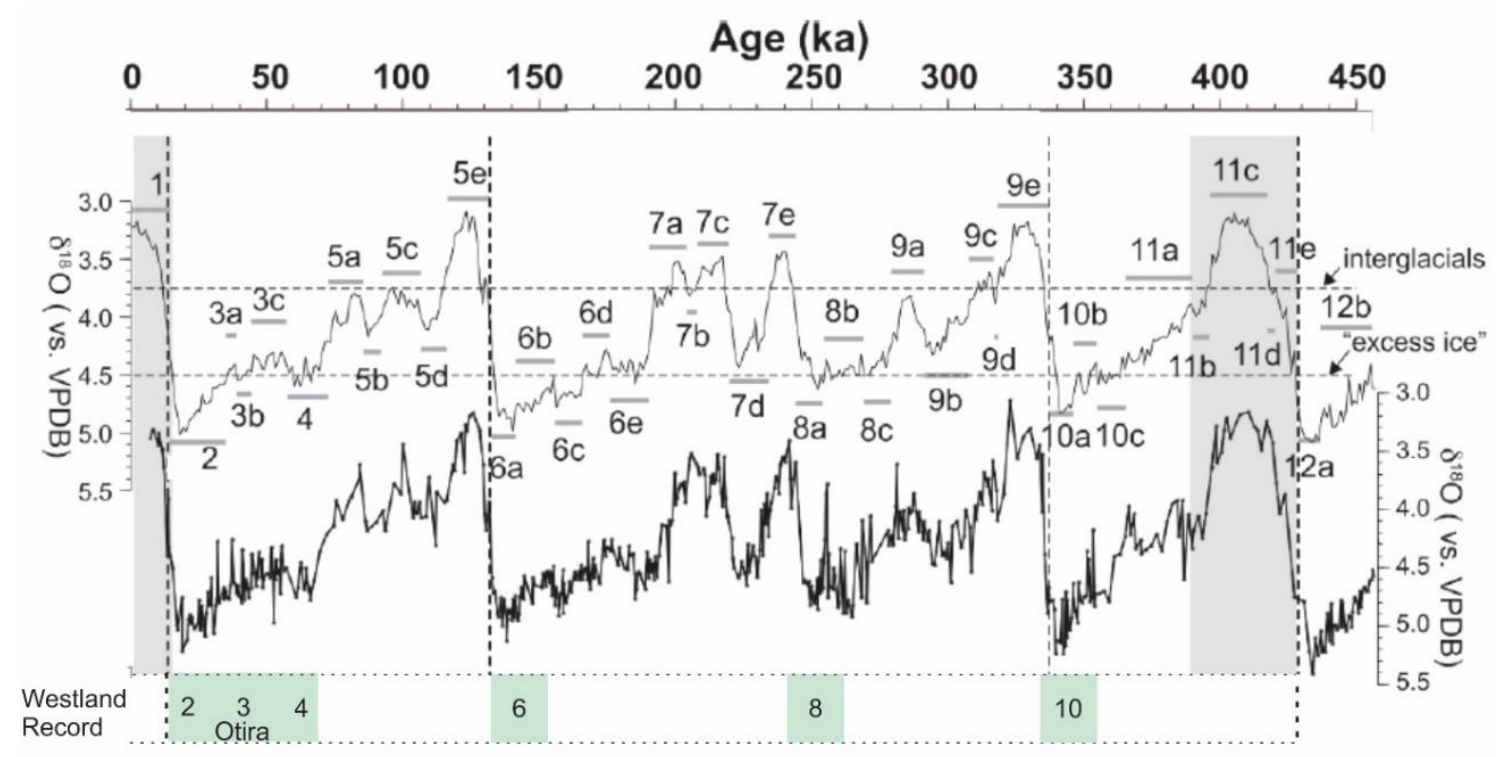

Figure 1.7 Stacked marine benthic oxygen isotope records LRO4 (Top) (Lisiecki and Raymo, 2005), with Southwest Pacific marine oxygen isotope record (Elderfield et al., 2012). Marine isotope stages annotated 1-12, with full glacial (excess ice) and interglacial conditions identified. Periods of glacial advance recognised by glaciogenic landforms in Westland denoted in green. Figure modified from Ryan (2017).

\subsubsection{Last Glacial Maximum}

The glaciogenic landform record from the LGM ( MIS 2$)$ is significantly better preserved than prior glaciations, with well-constrained glacial maxima across a number of catchments in the Westland region (Figure 1.8, Figure 1.9) (Barrell, 2011). Detailed studies of LGM glaciogenic landforms, coupled with terrestrial ecological proxies reveal the LGM to have been significantly more complex than first thought (Suggate and Almond, 2005) with evidence that ice advance occurred prior to $30 \mathrm{kyr}$.

The LGM has been defined as the period of Northern Hemisphere ice sheet maxima, constraining age limits to between 19-26 kyr (Clark et al., 2009). Though global maximum ice extent was achieved at $21.0 \mathrm{kyr}$ (Mix et al., 2001), projects such as New Zealand INTIMATE (Integration of Ice core, Marine, and Terrestrial records) show evidence that full-glacial climatic conditions occurred prior to this, as early as MIS 3 (Alloway et al., 2007).

Proceeding the realisation that full glacial conditions existed in New Zealand prior to global maximum ice volume, a number of locally derived terms were proposed, intended to include pre-MIS 2 cooling. Such periods include the extended LGM 
(Newnham et al., 2007, Callard, 2011) and the Last Glacial Cold Period (Alloway et al., 2007, Barrell, 2011).

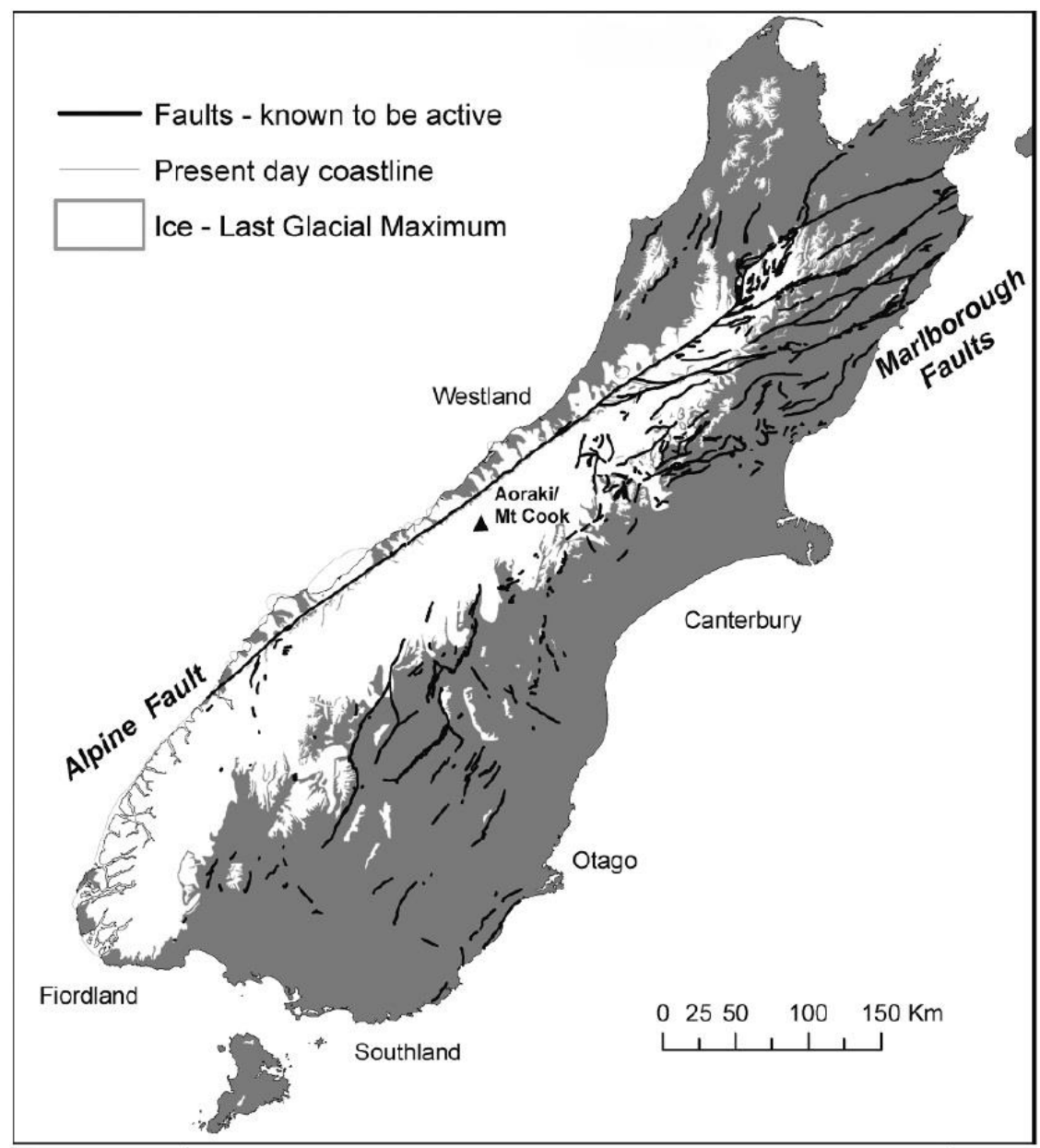

Figure 1.8 LGM ice extent in the South Island, mapped using the location of moraine sequences. Ice extent is overlain by mapped active faults. Figure developed by Barrell et al. (2005), then modified by Cox and Sutherland (2007).

From a glaciogenic landform perspective, glacial deposits encompassing MIS 4, 3 and 2 are grouped as part of the Otira Glaciation, a local convention introduced by Suggate (1990) used in the discussion of Westland glacial sequences (Table 1).

Otiran glacial deposits are regarded as glaciogenic deposits representing MIS 4, sparse cool climate deposits representing MIS 3, and well preserved, complex glaciogenic deposits of $\sim$ MIS 2 (Suggate, 1990, Suggate and Almond, 2005). Within the LGM age limits defined by Clark et al. (2009), two distinct periods of ice advance are recognised, represented by the M5 and M6 moraine sequences, which are also grouped as the Moana Formation (Almond et al., 2001). Older MIS 2 glacial deposits are also recognised in the Westland region, grouped as the Larrikins Formation (Table 1, Figure 1.9) (Suggate and Almond, 2005). 
In the Whataroa-Wanganui region relatively complete preservation and chronology of M5 and M6 surfaces allows the spatial relationship between the respective glacial advances to be examined (Suggate and Almond, 2005). Whilst the distance of ice recession between the M5 and M6 advances cannot be evaluated, in some valleys M6 moraines are observed to extend further down valley than M5 (Suggate and Almond, 2005). This suggests the most extensive MIS 2 ice advance in South Westland occurred during the latest LGM.

While there is no chronology of M6 recessional moraines, Suggate and Almond (2005) suggest the M6 advance to culminate at 19,000 cal.yr BP, followed by rapid glacial retreat with potential for lakes to develop in some West Coast catchments.

Table 1 Integrated periods of Otiran ice advance in South Westland. Modified from Suggate and Almond (2005).

\begin{tabular}{|c|c|c|c|c|}
\hline Terminology & MIS & North Westland Formation & South Westland Moraine (Almond et al., 2001) & Intergrated Westland periods of advance \\
\hline \multirow[t]{3}{*}{ Interglacial } & & 1 & & \\
\hline & & Moana & M6 & $20,500-19,000$ cal. yr BP \\
\hline & & & M5 & $24,500-21,500$ cal. yr BP \\
\hline \multirow[t]{2}{*}{ Otira Glaciation } & & 2 Larrikins & & \\
\hline & & & $\mathrm{M} 4 \mathrm{~b}$ & $34,000-28,000$ cal. yr BP \\
\hline Older Otiran & & 3 & & \\
\hline
\end{tabular}

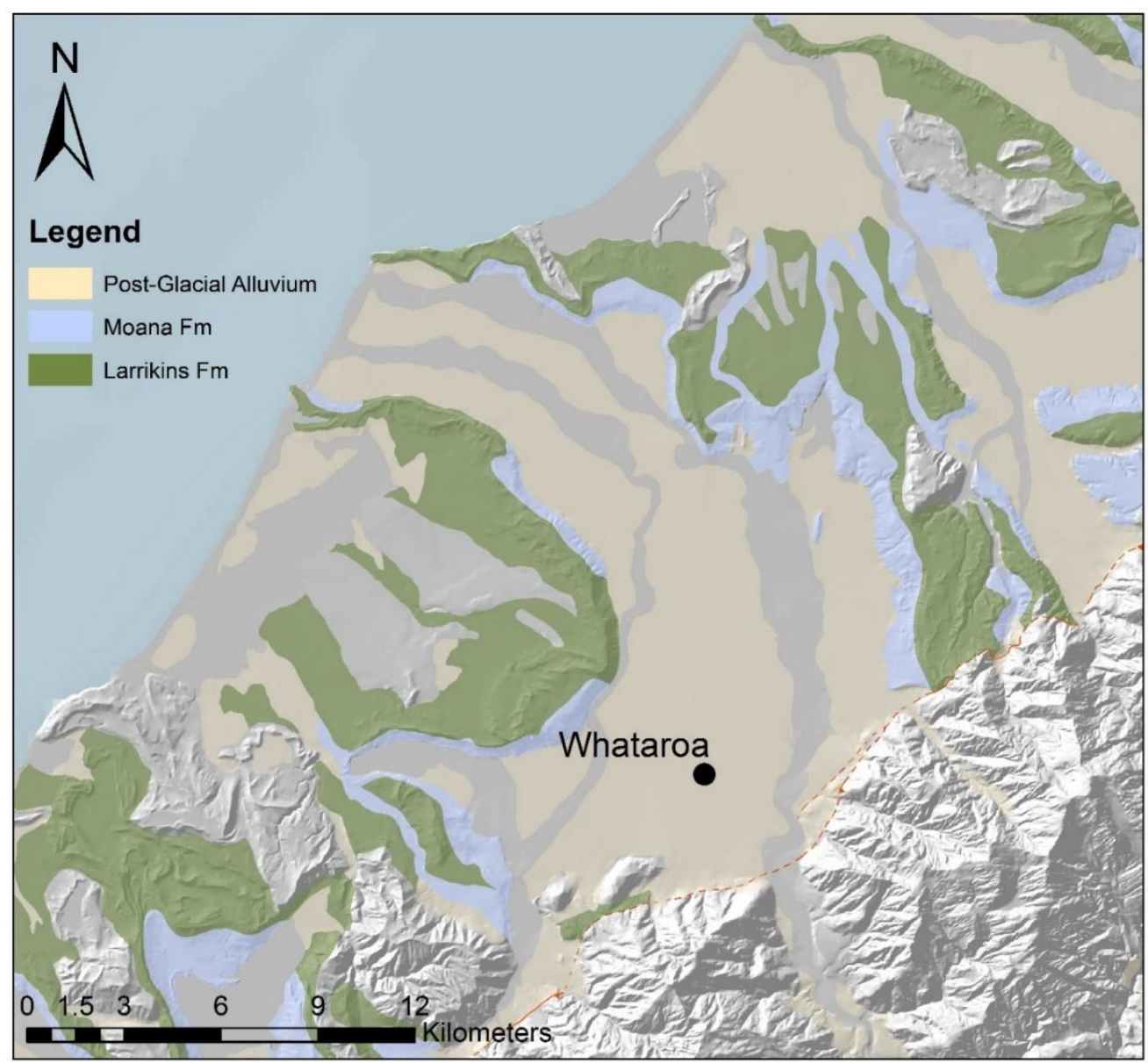

Figure 1.9 Otiran glacial deposits (Moana and Larrikins Fm) in the Whataroa region, delineating Otiran ice extent. Formations mapped by Barrell et al. (2013). 


\subsection{Last Glacial Maximum climate conditions}

\subsubsection{Terrestrial conditions}

Reconstructions of Westland climatic conditions during and immediately post LGM are derived from palynological records in the region (Moar and Suggate, 1996, Vandergoes et al., 2013). Three stadial periods of cold, sub-alpine or alpine conditions are recognised between 30,000 and 18,000 cal. yr BP, interceded by milder interstadial periods (Vandergoes et al., 2013). Stadial periods are stated to be significantly colder than present, with interstadials being similar or cooler than present.

A pollen record derived from Okarito bog in Westland was used by Newnham et al. (2012) to reconstruct LGM climate conditions. During stadial periods, mean air temperatures (MAT) of $\sim 5-6{ }^{\circ} \mathrm{C}$ were calculated, with MAT's of $\sim 7-8{ }^{\circ} \mathrm{C}$ during interstadials. These calculations represent mean annual temperatures that are $\sim 6{ }^{\circ} \mathrm{C}$ and $\sim 4.5^{\circ} \mathrm{C}$ cooler than present.

A number of paleo-temperature proxies have been used to reconstruct LGM air temperatures in the South Island. Temperature reconstructions developed using biotic proxies (Chironomids, beetle counts), suggest conditions $\sim 2-4{ }^{\circ} \mathrm{C}$ cooler than present (Marra et al., 2006, Woodward and Shulmeister, 2007). Glacier and climate model simulatons consistently suggest temperatures of $\sim 5-7^{\circ} \mathrm{C}$ cooler than present, in line with palynological reconstructions (Golledge et al., 2012, Drost et al., 2007, Callard, 2011).

Estimates of paleo-precipitation through the LGM are significantly more difficult to constrain. Variations in isotopic compositions in South Island speleothems were used to suggest the LGM was overall drier than present, with occasional wet periods (Whittaker et al., 2011).

\subsubsection{Marine conditions}

Sea surface temperature (SST) reconstructions using alkenone proxies show LGM SST's in the western Tasman Sea to be $\sim 4-6^{\circ} \mathrm{C}$ cooler than present (Pelejero et al., 2006). These findings are consistent with $\mathrm{Mg} / \mathrm{Ca}$ and alkenone reconstructions east of New Zealand, which show $\sim 4-6{ }^{\circ} \mathrm{C}$ of cooling north, and up to $8{ }^{\circ} \mathrm{C}$ south of the Chatham Rise (Weaver et al., 1998, Nelson et al., 1993). 
Marine core SO163-GH3, drilled off the Westland continental shelf shows two distinct pulses of sedimentation occurring between 30 and $18 \mathrm{kyr}$, inferred to correlate to periods of glacial advance (Callard, 2011). Interestingly, the second pulse is dated at 18.4 kyr, occurring after the M6 glacial advance (Alloway et al., 2007).

\subsection{Last glacial-interglacial transition (LGIT)}

The LGIT is defined as the period between 17.9 and $14.1 \mathrm{cal}$. yr BP, representing the emergence from excess ice LGM conditions (Alloway et al., 2007). Globally, ice core and deep marine oxygen isotope records show progressive climatic warming through the LGIT, which occurred until the onset of the Antarctic Cold Reversal (ACR) at 14.1 kyr (Delmonte et al., 2002, Johnsen et al., 2001). Climate reconstructions from the South Westland region through the LGIT are predominantly derived from palynological records (Vandergoes and Fitzsimons, 2003, Callard, 2011, Newnham et al., 2007, Newnham et al., 2012).

\subsubsection{Timing of deglaciation}

The transition from glacial silt to organic sediment deposition in a lowland depression was used by Vandergoes and Fitzsimons (2003) to mark the onset South Westland deglaciation. ${ }^{14} \mathrm{C}$ chronology indicates this transition to have occurred prior to 18,300 cal. yr BP at a site on Gillespies Beach Rd, coinciding with a change in the vegetation record, related to a decline in alpine grassland species. At Okarito Bog, the expansion of shrubland species is observed at 17,400 cal. yr BP, requiring climate amelioration to occur prior to this.

These findings are broadly consistent with the M6 moraine chronology of Suggate and Almond (2005) collectively implying a transition from glacial advance to retreat in Westland between $\sim 19,000$ and $\sim 18,300$ cal. yr BP.

\subsubsection{Terrestrial and marine conditions}

Temperature reconstructions from palynological records at Okarito Bog (Newnham et al., 2012) show a general MAT increase of 2.5 degrees between 18,000 and 15,000 cal. yr BP. Before the onset of Antarctic Cold Reversal (ACR) associated cooling, estimated MAT is $9.5 \pm 1.5^{\circ} \mathrm{C}$, sitting within $\sim 2{ }^{\circ} \mathrm{C}$ of modern values in South Westland. SST reconstructions show a rapid rise in temperature off South Westland, 
with alkenone proxies showing $\sim 5^{\circ} \mathrm{C}$ of mean SST increase during the LGIT (Pelejero et al., 2006).

Alongside SST increases was progressive sea-level rise associated with mass loss from high latitude ice sheets (Figure 1.10). The peak global ocean low stand during the LGM is constrained to $132 \pm 4 \mathrm{~m}$ at $\sim 21,000 \mathrm{kyr}$, with sea level rapidly increasing to $100 \pm 3$ m by 15,000 kyr (Lambeck et al., 2014). In the Paringa valley, South Westland, sealevel rise coupled with glacial retreat caused the development of a fjord, where a fossiliferous shallow marine silt was deposited at 16,500 cal. yr BP (Suggate et al., 1968).
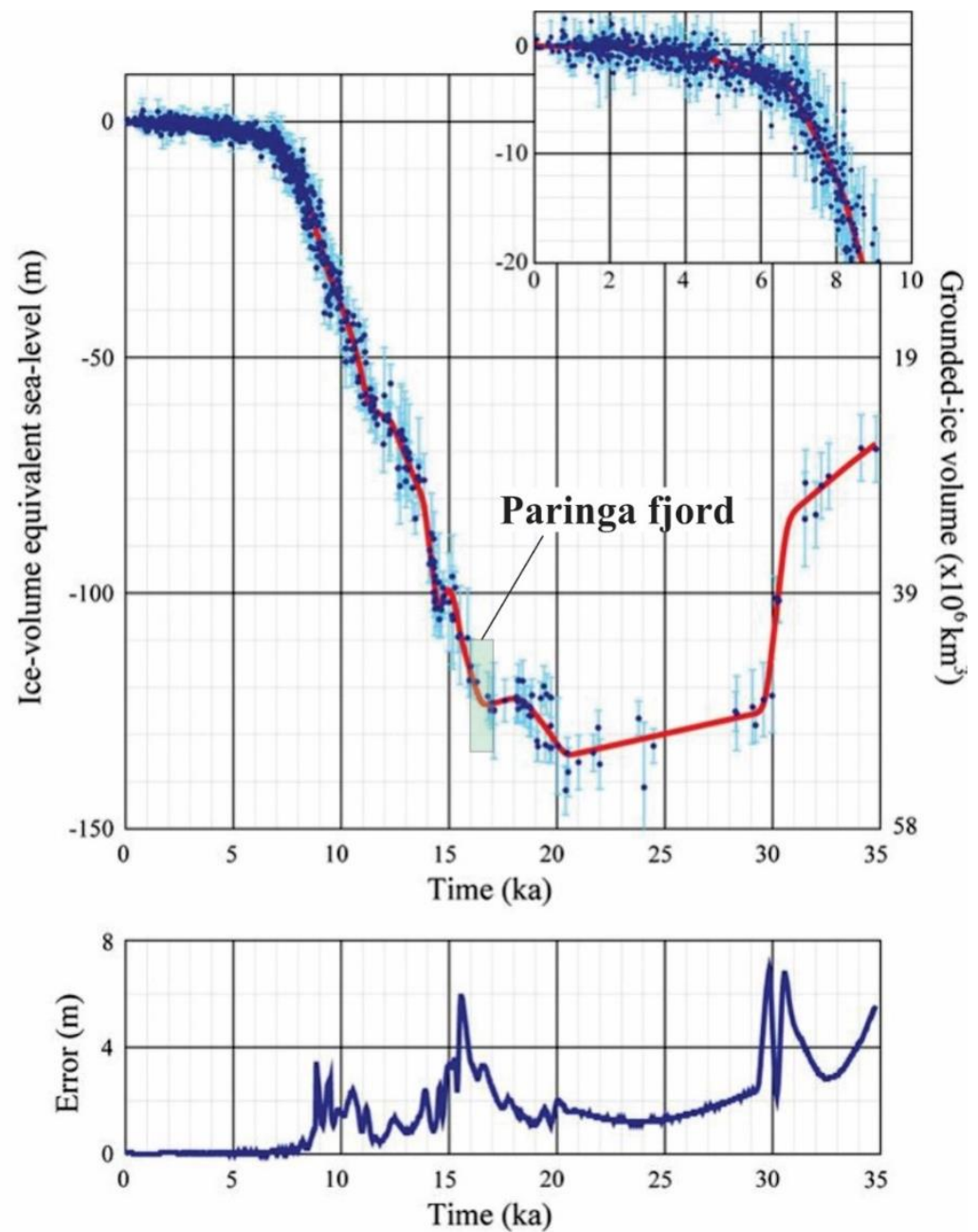

Figure 1.10 Global sea level curve from the LGM to present, with the development of the Paringa fjord annotated (Lambeck et al., 2014).

\subsection{Behaviour of maritime glaciers}

\subsubsection{Temperature and precipitation}

The advance and retreat of maritime glaciers is modulated by the dual influences of temperature and precipitation (Anderson and Mackintosh, 2006). Determining the 
relative influences of these factors on glacier mass balance, alongside the influences of bed slope and debris cover has presented a challenge in glaciology. The response of West Coast glaciers to past and recent climatic change has allowed the relative effects of these drivers to be quantified however (Braithwaite et al., 2002, Anderson and Mackintosh, 2012).

Mass balance modelling by Anderson and Mackintosh (2012) supported by prior research (Anderson and Mackintosh, 2006, Oerlemans, 1997) showed temperature to be a dominant control on the extent of West Coast glaciers. This modelling suggested that to offset $1{ }^{\circ} \mathrm{C}$ (reported as $1 \mathrm{~K}$ ) of overall warming, an $82 \%$ increase in precipitation was required to maintain mass balance.

LGM temperature and precipitation reconstructions have been used to evaluate the influence of temperature and precipitation on glacier extent. To fit LGM and ACR ice fields, model reconstructions (Golledge et al., 2012, Anderson and Mackintosh, 2006) used variable temperature depressions to control ice extent. Both models were able to model mapped ice extent using temperature depressions within the range of paleotemperature estimates for the respective periods, without invoking significant precipitation changes.

Further, paleoclimate and paleocirculation reconstructions by Lorrey et al. (2012) infer the dominant atmospheric circulation to have been an anticylonic/zonal regime during the LGM, producing low MAT's, and overall decreased precipitation over the Southern Alps. This is supported by speleothem studies by Whittaker et al. (2011) who showed the LGM to have been overall drier than present.

These findings strongly suggest temperature to be the dominant control on glacier extent, as if precipitation was a dominant control, significant increases would be required to achieve mapped LGM ice extent, which is not supported by the above studies.

\subsubsection{Other variables}

The sensitivity of central Southern Alps glaciers is also affected by parameters including topographic profile, bed slope, shading, debris cover and pro-glacial lake development. 
Anderson and Mackintosh (2012) identify debris cover as having a significant impact on glacier mass balance, acting to insulate the glacier surface and inhibit melting. With $>35 \mathrm{~cm}$ of debris cover, glacier ablation caused by ambient temperature or incoming solar radiation is shown to be near completely inhibited (Brook et al., 2013).

Modern West Coast glaciers are observed to host increasing loads of debris cover, especially in the ablation zone as glaciers undergo down wasting and retreat. At Franz Josef and Fox glaciers, this is observed as the formation of well-developed medial moraines on the glacier surface (Brook et al., 2013, Brook et al., 2017). Much debris cover originates from rock avalanches, whose scale and frequency may increase due to climate change, or a large earthquake on the Alpine Fault (Allen et al., 2011).

\subsubsection{Erosion mechanisms}

Glaciers erode bedrock through direct abrasion of the bedrock surface, as well as quarrying (plucking), sub-glacial fluvial erosion, and dissolution of the bedrock surface (Drewry, 1986). Of these processes, the dominant erosive mechanisms is thought to be abrasion and quarrying processes (Herman et al., 2015).

Herman et al. (2015) use a novel approach to evaluate modern glacial erosion by Franz Josef Glacier, quantifying glacial erosion rates and ice sliding velocity to explore the relationship between the two parameters. Erosion rates calculated from suspended sediment loads are estimated at $10 \mathrm{~mm} / \mathrm{yr}$, with instantaneous erosion rates varying from $\sim 1$ to $500 \mathrm{~mm} / \mathrm{yr}$, the largest values occurring during large rainfall events (Herman et al., 2015).

By quantifying the source of sediments carried in the glacial stream, glacial erosion was quantified spatially, observed to mimic ice velocity patterns, where maximum erosion rates occurred at the steepest, faster flowing regions of the glacier (Herman et al., 2015).

These findings are used to show that glacial erosion rate is proportional to the square of ice sliding velocity, implying that erosion is highly sensitive to topographic slope. In the high bed-slope glaciers of the central Southern Alps, this relationship demonstrates that glaciation can have a powerful effect on landscape erosion and sediment transport. 


\subsubsection{Retreat mechanisms and response times}

Mass loss by a glacier occurs via two main mechanisms; retreat of the glacier terminus, down wasting of the glacier surface, or any combination of the two (Oerlemans, 1994). These processes result in significant changes in glacier geometry. The time taken for mass balance changes to be expressed as significant changes in glacier geometry is termed the glacier response time. Presently, the high mass turnover of glaciers west of the Main Divide leads to response times in the order of 6-10 years (Oerlemans, 1997, Anderson and Mackintosh, 2012).

\subsection{Formation and deposition in pro-glacial lakes}

A common feature associated with the retreat of glaciers is the development of a proglacial lake. Pro-glacial lake sedimentary records have the potential to be highresolution paleo-environmental archives, and therefore lake development and sedimentation into pro-glacial lakes has been studied in detail.

\subsubsection{Pro-glacial lake formation}

The formation of pro-glacial lakes represents a significant stage associated with glacial retreat, as the dominant method of glacier mass loss switches from melting to ice calving (Kirkbride, 1993). This transition acts to decouple the glaciers net mass balance from climatic controls, with lake dynamics beginning to exert a major control on mass balance (Warren, 1991).

The $20^{\text {th }}$ century development of pro-glacial lakes in alpine regions presents an opportunity to analyse the processes involved in developing a pro-glacial lake during glacial retreat, discussed by Kirkbride (1993) and more recently Sakai (2012).

Evidence from the Bhutan Himalayas, as well as Tasman pro-glacial lake, New Zealand, shows ponding on low angle glacier surfaces to be the initial phase of lake development (Quincey et al., 2007, Kirkbride, 1993). The formation of ponds on the glacier surface is modulated by the extent of debris cover, being more likely to develop where cover is thin (Figure 1.11).

At Tasman Glacier, surface ponding is observed to coincide with a general down wasting of the glacier surface, a process which lowers the glacier surface relative to the outwash head or terminal moraine (Kirkbride, 1993). This represents an important stage 
in the development of a stable pro-glacial lake, allowing terminal and lateral moraines to develop into pinned lake damming surfaces (Sakai and Fujita, 2010) (Figure 1.11).
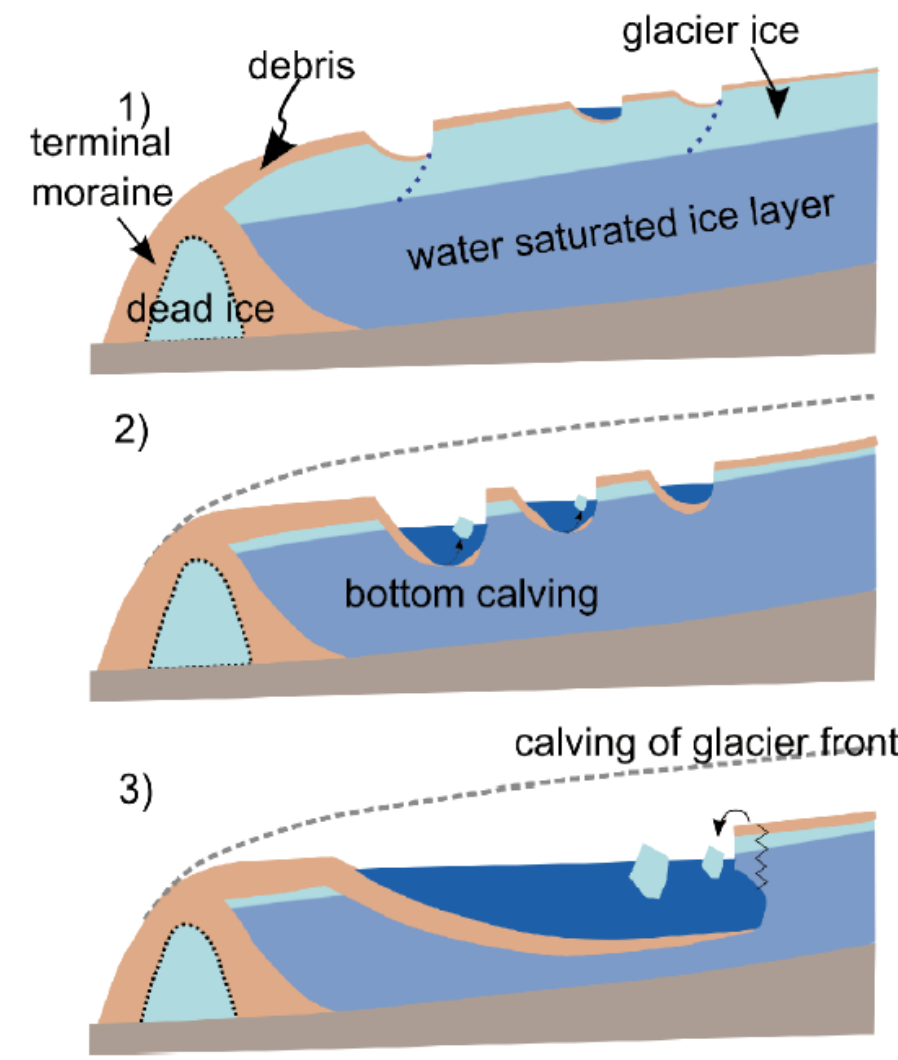

Figure 1.11 Schematic for the initiation and expansion of pro-glacial lakes associated with debris covered glaciers Note the inhibition of melt at the glacier snout by heavy debris cover. Figure from Sakai (2012).

Kirkbride (1993) observed the development of connectivity between supra-glacial lakes, into a single coherent lake body to occur within a few decades of initial ponding on Tasman Glacier. In this phase, the initial lake may be bordered by ice, allowing ice to calve into the lake from each side (Sakai, 2012). Following the development of a single lake body, relatively rapid deepening and widening of the lake occurs due to calving and disintegration of the ice floor. Calving at the ice front is accelerated by the detachment of ice from bedrock to develop a floating ice tongue, allowing water to percolate under the grounding line (Benn et al., 2007, Sakai, 2012).

Glacier calving as the dominant mode of mass loss will continue to occur as the glacier retreats back over its glacial trough and the pro-glacial lake increases in size. This process continues until the glacier termini reaches sufficient elevation to be grounded again (Kirkbride, 1993). 
At Tasman Glacier, the terminus position was observed to stagnate in the proglacial lake for a period, with the glacier surface dominantly losing mass via down wasting. Kirkbride (1993) discussed this phase of development as largely a transitory one, where on centennial to millennial timescales the transition between melting and calving, and the associated terminus retreat is virtually instantaneous.

\section{Westland pro-glacial lakes}

A series of moraine-dammed lakes are present on the Westland piedmont, occupying remnant LGM glacial troughs (Figure 1.12). With modern glaciers receding significant distances up-catchment, sediment influx into these lakes is largely unaffected by the influence of glaciers. Lake sedimentation is dominated by stacks of turbidites, deposited via hyperpycnal flows during storm events (Howarth et al., 2012).

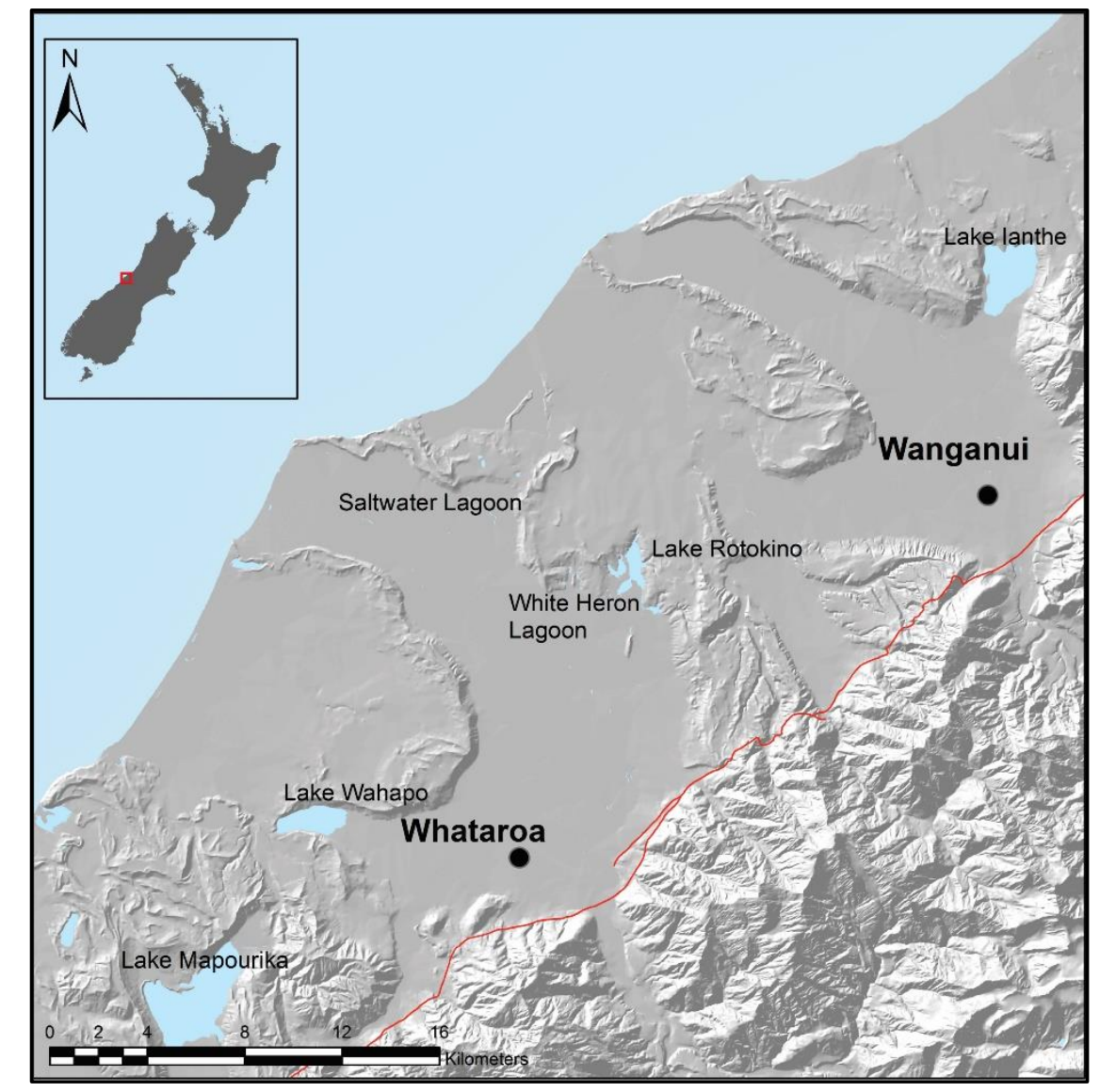

Figure 1.12 Location of moraine dammed lakes (blue polygons) in the Whataroa-Wanganui region, Westland piedmont. Lake position defined by the LINZ lakes dataset. Alpine Fault mapped by Cox and Barrell (2007).

The presence of remnant lakes distal from the Westland range-front suggests that lake formation in response to LGM ice retreat may have been common. With lakes presently persisting at moraine limits, it is likely that large pro-glacial lakes would have formed on the Westland piedmont, occupying glacial troughs during ice retreat. Presently, little 
is known about the extent and formation of, as well as deposition into Westland proglacial lakes.

Sedimentation into these lakes is expected to have differed from processes in modern Westland lakes, due to the influence of large ice masses terminating proximal or into the pro-glacial lake body. Further, due to significant differences in catchment and piedmont geometry, topography, climate and precipitation, it is likely that pro-glacial lake formation on the Westland piedmont would have occurred through different mechanisms than modern examples such as Tasman pro-glacial lake.

Understanding processes of pro-glacial lake formation and sedimentation, as well as defining pro-glacial lake extent has important implications for the deglaciation and landscape evolution of the Westland region.

\subsubsection{Sedimentation into pro-glacial lakes}

Glacio-lacustrine depositional environments are characterised by the interaction of a number of depositional processes, producing complex facies assemblages (Eyles et al., 1985). Understanding and interpreting glacio-lacustrine sedimentary successions can have important paleoclimatic implications, as well as implications for the history of individual glaciers. This section will discuss sedimentation into pro-glacial lakes, distinguishing the depositional environment into two main types; Ice contact and Ice distal (Lønne, 1995).

\section{Ice Contact settings}

Ice contact glacio-lacustrine settings occur when the glacier ice mass and pro-glacial lake are in direct contact (Figure 1.13), with no sub-aerial (fluvial) plain between the glacier and lake body (Lønne, 1995).

Fine to coarse grained sedimentation into ice contact glacio-lacustrine settings is derived from two main sources: 1) unsorted sub-glacial diamict material derived from the glacier terminus. 2) outwash material supplied by the outflow of glacial melt water, including sub-glacial, supra-glacial, englacial and pro-glacial transport mechanisms (Lønne, 1995).

Sediment supplied by glacial outflow is transported by two major mechanisms: 1) Coarse-grained sediments transported as bed-load. 2) Fine silt and sands transported by 
fallout from a buoyant meltwater plume, originating from sub or en-glacial channels (Powell, 1990). Sediment transport as ice rafted debris consists a minor, but important component of this depositional environment.

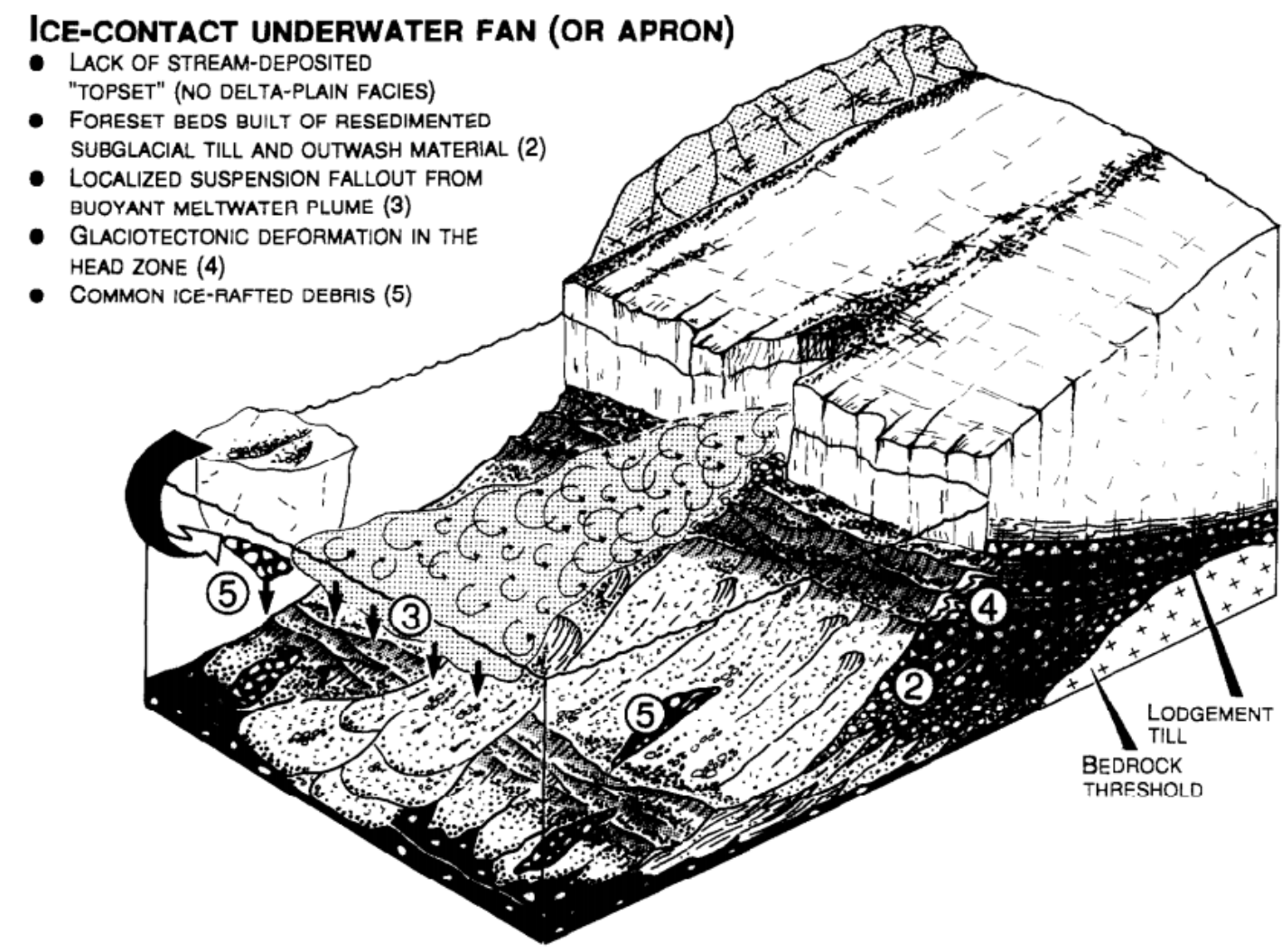

Figure 1.13 Depositional model for ice contact glacio-lacustrine depositional environments. Figure from Lønne (1995).

Ice contact glacio-lacustrine settings are typically formed during periods of glacial retreat. As pro-glacial lakes typically occupy over-deepened glacial troughs, the reworking of sediments by hydraulic processes (wave action) is minor as sediments settle well below wave base (Lønne, 1995). At lake margins, sediment reworking by hydraulic processes is expected to be more significant however.

Sediment supply to the glacier terminus leads to the development of an unstable, high angle depositional slope, displayed in Figure 1.13 (Eyles et al., 1985, Eyles et al., 1987). Sediment deposited on this slope is prone to re-sedimentation by gravitational processes associated with slope failure. Modes of sediment transport include sediment slides, slumps, debris flows and turbidity currents, producing stratified and unstratified deposits downslope (Eyles et al., 1987). 
Should sedimentation rates be significantly high, the depositional slope will prograde, developing foreset bedding and a sub-aerial component between the lake and glacier terminus. The development of this sub-aerial (fluvial) plain marks the evolution to an ice contact delta setting (Figure 1.14).

ICE-CONTACT DELTA

- Stream-Deposited topset (1)

- Foreset beds built of RESEDIMENTED OUTWASH MATERIAL AND STREAM-REWORKED TILL (2)

- Broader zone of suspension fallout FROM BUOYANT MELTWATER PLUME (3)

- glaciotectonic deformation (4)

- lack of ice-rafted debris

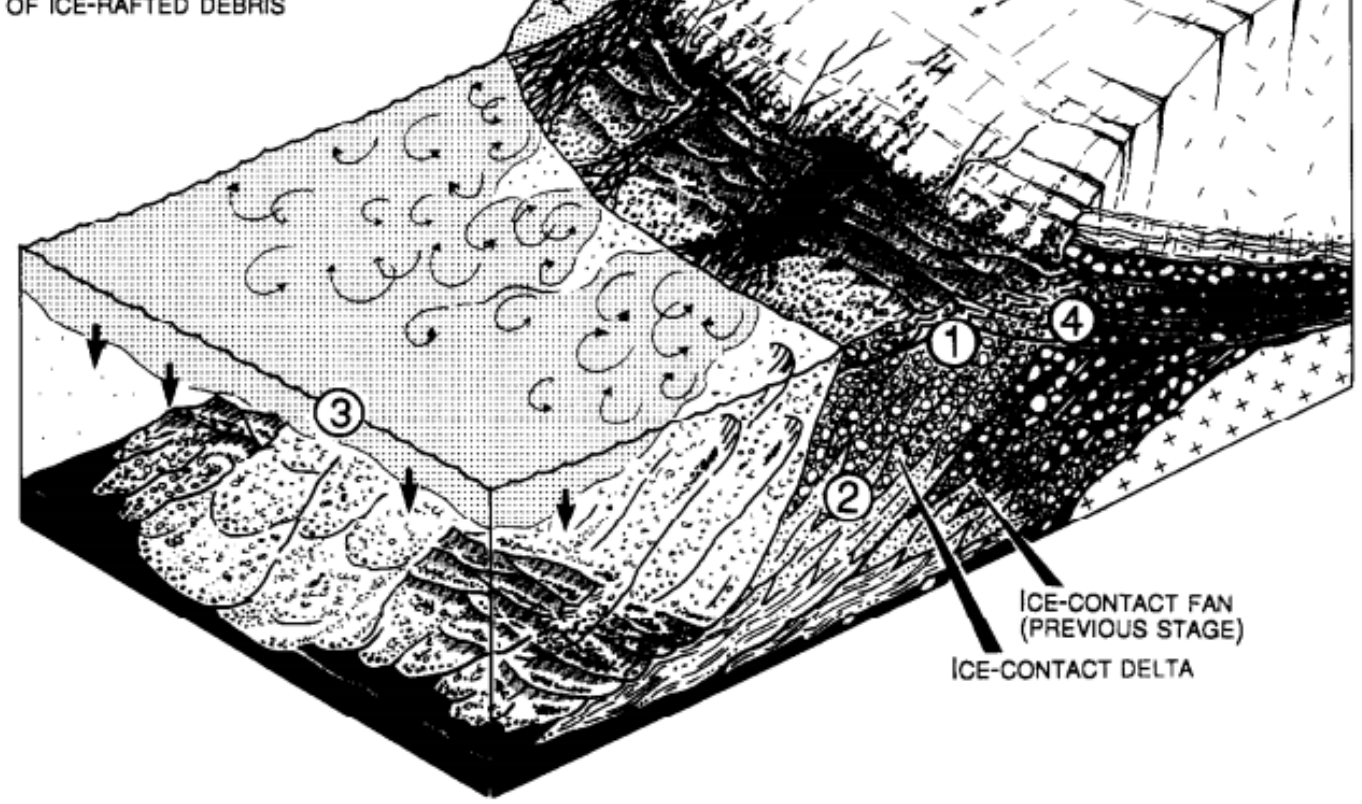

Figure 1.14 Depositional model for an ice contact delta depositional setting, with a minor sub-aerial component. Figure from Lønne (1995).

The evolution to an ice contact delta results in a change of facies assemblages, whereby meltwater plumes are issued into the lake from braided distributary channels as opposed to directly from the ice margin. Additional to this, the development of a sub-aerial plain requires outwash sediment to undergo a degree of fluvial transport across the distributary plain (Lønne, 1995). Sediment transport by ice rafting cannot occur in this setting.

In both ice contact settings (Figure 1.13, Figure 1.14), glacio-tectonic deformation of sediments can produce a wide range of characteristic deformation structures (Lønne, 1995, Mager and Fitzsimons, 2007). Though not discussed in detail here, where glaciotectonic deformation is recognised in sedimentary successions, it is a clear indicator that ice remains proximal to the depositional environment. 


\section{Ice Distal depositional settings}

The evolution from an ice proximal to ice distal depositional environment can occur due to glacier terminus retreat, sediment flux and delta progradation, or a combination of these processes (Eyles et al., 1985). With ice rafting and glacio-tectonic deformation no longer affecting deposition into the lake, the influence of glacier dynamics on sedimentation into the pro-glacial lake is decreased (Lønne, 1995). Glacier dynamics can still affect the volume of suspended material entering the pro-glacial lake, and the volume of outwash sediment deposited onto the fluvial distributary plain however (Lønne, 1995).

The glacio-fluvial depositional model displayed in Figure 1.15 shows the development of a distributary plain that leads to the deposition of fluvial topsets and well bedded delta foresets, comparable to non-glacial deltas (Eyles et al., 1985). More distal from the delta face, sedimentation is dominated by rainout from sediment plumes. Ice distal glacio-fluvial deposits are shown to overtop remnant ice proximal deposits in this model, termed pre-deltaic substratum.

\section{GLACIOFLUVIAL DELTA} (OUTWASH FAN/ SANDUR DELTA)

- Stream-deposited topset (1)

- Foreset beds BUILT of RESEDIMENTED OUTWASH MATERIAL (2)

- broad zone of suspension fallout FROM MELTWATER BUOYANT PLUME (3)

- Glaciotectonic deformation AFFECTING THE FLUVIAL SYSTEM'S INLAND HEAD-ZONE ONLY (4)

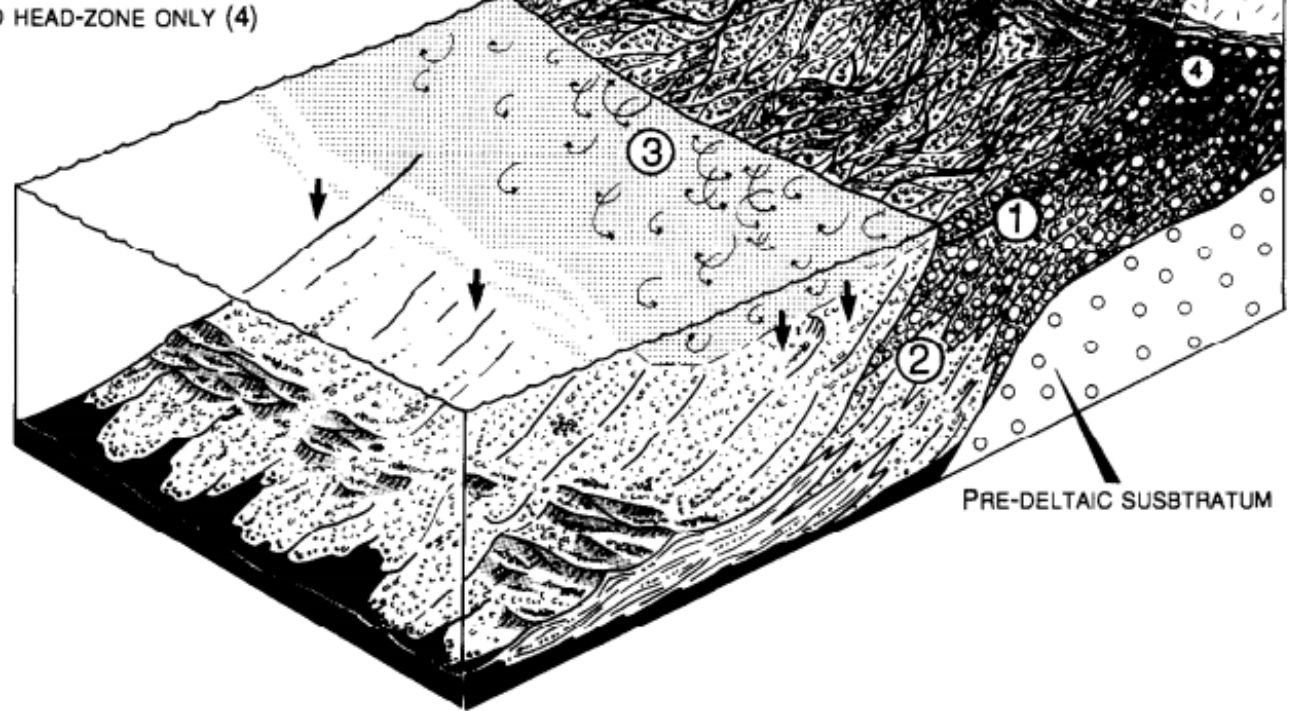

Figure 1.15 Depositional model for an ice distal glacio-fluvial deltaic depositional environment. Figure from Lønne (1995). 


\subsubsection{Use of pro-glacial lakes as paleo-climate archives}

Sediment entering pro-glacial lakes is dispersed as bottom, inter and surface flows. The development of these flows is controlled by water temperature, as well as the mode and volume of sediment entering the lake, all of which can be heavily influenced by seasonal cycles (Gierlowski-Kordesch, 2004). In Alpine regions, this seasonal cyclicity can produce annual laminations, termed varves (Gierlowski-Kordesch, 2004). This promotes the use of lake sediments as paleo-climate archives.

The presence of varve type sediments in glacial valley lakes on the eastern side of the Southern Alps has led to a significant volume of research examining their paleoclimatic implications. Most recently, the Lake Ohau Climate History ( $\mathrm{LOCH}$ ) project attempted to use laminated sediments for annual-decadal scale climate reconstructions. Annual laminations were shown to be produced by seasonal variations in lake dynamics and sediment inflow in the lake (Roop et al., 2015). Large flood events into the lake were also shown to produce large hyperpycnal deposits, accounting for up to $95 \%$ of annual sediment input into the lake proximal to the main inflow (Roop et al., 2015).

In modern Westland lakes, sediment input is dominated by hyperpycnal flow deposits triggered by storm events (Howarth et al., 2012). With catchments receiving significantly higher mean annual rainfall and more frequent storm events, no annual cycle in sedimentation has been identified or used as a paleoclimate proxy in Westland.

\subsection{Glacio-fluvial aggradation}

Pro-glacial outwash plains, also termed "sandar" are common features associated with temperate valley glaciers in New Zealand, as well as globally (Hambrey, 1994, Hambrey and Ehrmann, 2004). The formation, development and landforms associated with outwash plains are heavily influenced by the volume sediment supply to the system, as well as the frequency and magnitude of fluid and sediment transport events. The well-developed pro-glacial outwash plains associated with Franz Josef and Fox Glaciers display a broad range of glacio-fluvial landforms, analysed by Carrivick and Rushmer (2009) and Hambrey and Ehrmann (2004).

Despite the proximity of the two glaciers and catchments, significant differences in the glacio-fluvial landforms are observed. At Franz Josef Glacier, the high relief, boulderdominated outwash plain is characteristic of formation by large scale, episodic fluvial 
events, also termed jokulhlaups (Carrivick and Rushmer, 2009). This produces an outwash plain dominated by massive, poorly sorted deposits containing common outsized boulder clasts.

At the neighbouring Fox Glacier, the glacio-fluvial outwash plain is distinctly different, characterised by a low relief aggrading fluvial plain, and common para-glacial fan debris. This style of outwash plain is associated with lower energy glacio-fluvial accumulation processes, with Fox Glacier having no identified jokulhlaup events (Carrivick and Rushmer, 2009). This is attributed to Fox Glacier having increased paraglacial sediment supply, as well as a larger pro-glacial accumulation area. This inhibits the down-valley transport of para-glacial fan material from valley-side walls leading to well-developed alluvial and colluvial fan sequences in the Fox glacial valley (Carrivick and Rushmer, 2009, Hambrey and Ehrmann, 2004).

The discrepancies in glacio-fluvial zone architecture between neighbouring catchments (Franz Josef, Fox Glacier) shows the pro-glacial outwash region to be a dynamic zone heavily influenced by the presence or absence of jokulhlaups events. 


\section{Chapter 2 Methods}

\subsection{Sample collection}

Geological samples collected and analysed in this thesis are derived from two sources:

- Drilling as part of DFDP-2

- Samples collected from outcrop exposures in Westland.

As these sample collection methods are distinctly different, they are discussed individually below:

\subsubsection{Deep Fault Drilling Project 2}

DFDP-2 occurred as two phases of drilling, with boreholes DFDP-2A and DFDP-2B returning geological samples from the sedimentary sequence of interest (0-240 metres MD). Drilling methods, sample type and sample collection methods vary between boreholes, as discussed below:

\section{DFDP-2A}

Drilling methods used in borehole DFDP-2A varied as drilling progressed downhole, with geological samples retrieved as air and water circulated cuttings, as well as sediment core (Figure 2.1).

Interval 0-125.5 m: Cutting samples were returned to the top of the casing string via air circulation. Samples were separated from the circulating air using a cyclone, to then be collected in sampling buckets and sealed in labelled sample bags. The air circulation method is noted to cause some drilling related sorting of sediments, with coarse-grained pebble to cobble sized material being poorly excavated from the drill pipe to the cyclone. Coarse material was noted to settle between the drill bit and lowermost casing, until it was blasted out using high-pressure air at the end of each 6-metre casing run (Sutherland et al., 2015). Resultantly, individual samples from the 0-125.5 m interval may contain an integration of material from the overlying 6 metres of sediment. Depth 
positions within this interval should therefore be considered to have an error of \pm 6 metres.

Bagged sediments were returned to the GNS Science laboratory, where excess water was removed and samples dried in a $40{ }^{\circ} \mathrm{C}$ oven. The samples were then disaggregated before being re-bagged for storage and further analysis.

Interval 125.5-160.2 m: Sediment core was recovered using the Advanced Core Rotary Barrel (ACRB) drilling system, with a PQ3 drill bit. Coring was carried out in 1.5-metre runs, with core recovering varying from $0-100 \%$ and some drilling induced deformation observed. The drilling fluid used during coring was water extracted from a nearby creek, presenting a potential source of contamination to samples. To minimise drilling induced contamination, samples were extracted from the interior of split core intervals.

Recovered core was then divided into $0.5 \mathrm{~m}$ intervals for bagging. Bagged core runs were returned to the laboratory to be split, photographed, logged and archived. Core was also sub-sampled at intervals of interest, fossil organic material removed and clasts examined using methods outlined in Section 2.7.

Interval 160.2-206.0 m: Cuttings samples were returned to the top of the casing string using water circulation. Samples were then collected in sample buckets at depth intervals ranging 2-20 metres, before being transferred into labelled sample bags. Samples were returned to the laboratory and processed using the same method described for interval 0-125.5 metres.

Interval 206.0-212.6 m: Sediment core was recovered using the systems and methods described for interval 125.5-160.2 metres. As the sedimentary sequence drilled through was dominated by poorly cemented pebble-cobble clasts, core recovery through this interval was poor. Recovered core was separated into $0.5 \mathrm{~m}$ segments for storage, however core from this interval unable to be split due to the presence of cobble clasts, and the lack of a fine-grained matrix. Clasts recovered were analysed using the methods outlined in Section 2.4 . 

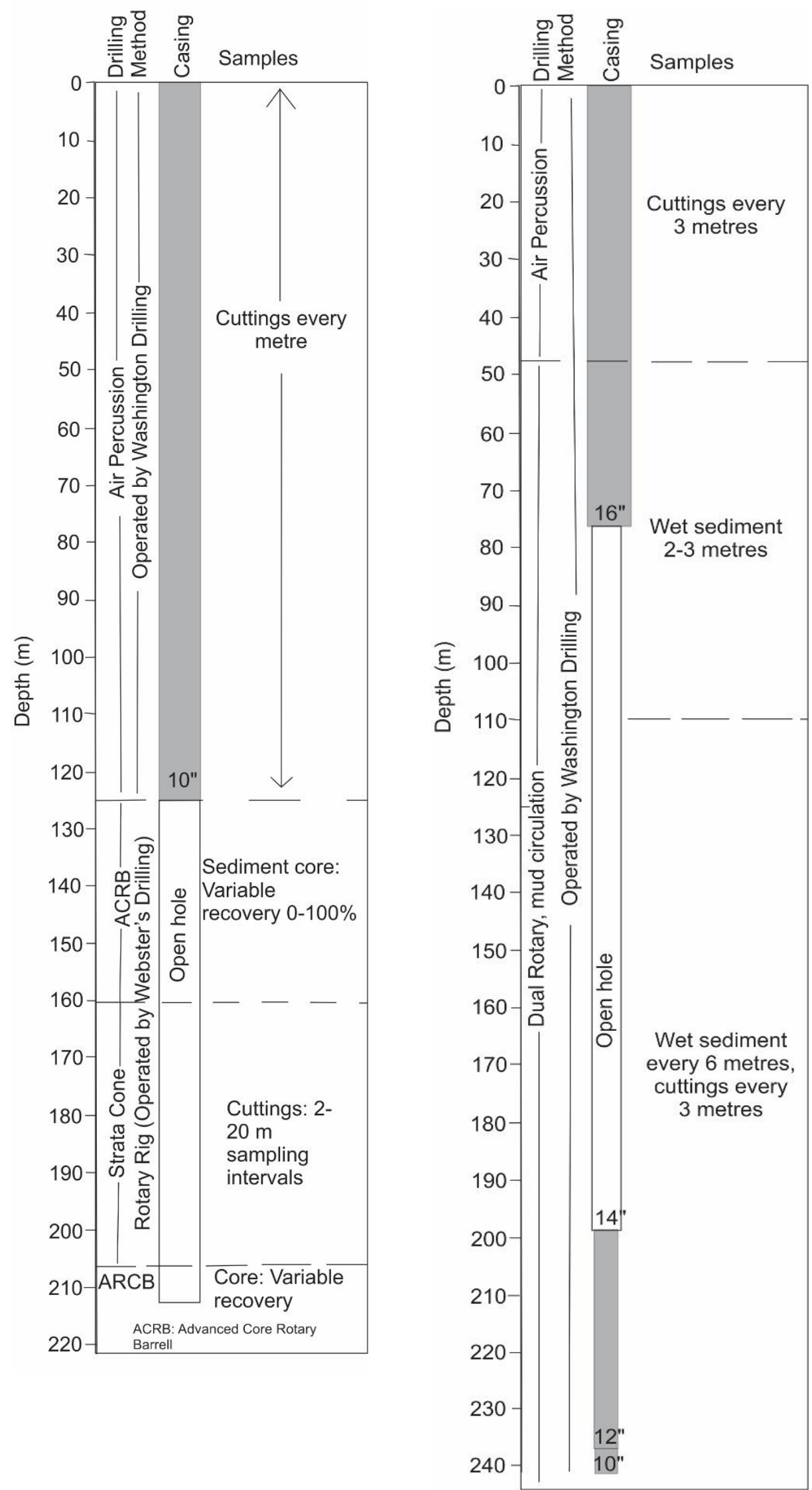

Figure 2.1 Summary log for Boreholes DFDP-2A (left), DFDP-2B (right) Modified from Sutherland et al. (2015). 


\section{DFDP-2B}

Drilling methods and sampling intervals varied with advancement downhole, therefore depth intervals are discussed individually. As DFDP-2B was drilled directly after DFDP-2 A, and intercepted the same sedimentary sequence, a wider sampling interval was used than in the first borehole (Figure 2.1).

Interval 0-47.0 m: Cuttings samples were collected at 3-metre depth intervals, using the drilling methods outlined for interval 0-125.5 $\mathrm{m}$ in DFDP-2A. Samples were also processed using the same methods outlined for interval 0-125.5 $\mathrm{m}$ in DFDP-2A.

Interval 47.0- 240.0 m: Sediment samples produced as drill cuttings were returned and collected in sample bags at 2-6 metre depth intervals. Drilling mud was used as the circulating fluid, which composed water derived from a nearby creek, with the addition of CR-650 polymer based drilling mud. This drilling fluid presents a potential source for the contamination of geological samples for this interval. Where possible, samples retrieved by DFDP-2A, with less potential for contamination are preferred for analysis. Samples from DFDP-2B were then heat sealed in sample bags, and returned to the laboratory. Before drying and disaggregating following the methods outlined for DFDP2A interval 0-125.5 metres, excess drilling fluid was skimmed and poured off the bagged samples.

\subsubsection{Field mapping}

Prior to field study being undertaken, the 1:250,000 Geological Map of New Zealand (QMAP) was examined, alongside the CSIGG database (Rattenbury and Isaac, 2012, Barrell et al., 2013). These resources were used to identify locations for field study. Areas of interest were identified as known, unmapped sedimentary sequences outcropping in the Westland region, as well as mapped sequences in the Paringa (Suggate et al., 1968) and Whataroa rivers (Klahn, 2011). Outcrop exposures were also sought near the mapped extent of the Moana Formation in the Whataroa Region.

An initial field campaign was undertaken with the purpose of locating, identifying and sampling both mapped and unmapped sedimentary sequences. Field mapping was completed in the Paringa, Waitangitaona, Whataroa, Wanganui, Styx and Arahura River valleys, with outcrop exposures targeted proximal, or upstream of the range front in the respective valleys. Where field sites of interest were identified, station locations were 
marked using a Garmin eTrex 10 handheld GPS. At each station location, outcrop photos were taken along with full outcrop descriptions, including strike and dip data where available.

A later field campaign was undertaken to map and define the extent of key outcrops identified during the first campaign. Field sites in the Arahura, Whataroa and Waitangitaona Rivers were revisited, with positions and elevations recorded using a Trimble D-GPS. Data was then post-processed to refine locations to $\pm 30 \mathrm{~cm}$ positional accuracy.

\subsubsection{Measured sections and sampling}

Sections were measured at key field sites in the Waitangitaona and Arahura River valleys (Figure 1.2, Figure 1.3). Field localities were chosen as they were thought to represent a broad range of depositional environments associated with post-glacial sedimentation. Sections were measured using a geological compass, $30 \mathrm{~m}$ tape measure, surveying tripod and labelled marker nails. Sections were then logged and described in the field, and further reviewed using georeferenced image based models (Section 2.2).

Outcrops were cleared and excavated where required for sampling and orthophotography. Sediment and bulk rock samples were collected from positions of interest in outcrops, and the stratigraphic position of samples recorded in field notes. Bulk sediment samples were also sieved on site using a $200-\mu \mathrm{m}$ mesh size, as well as a gold pan, with the intention of concentrating and recovering fossil organic material. Samples were taken to GNS Science Dunedin and Victoria University of Wellington for processing.

Sediment samples were dried in a $40{ }^{\circ} \mathrm{C}$ oven and disaggregated. Samples were then rebagged for storage and further analysis. A table of sample names and location collected is available in Appendix A2.

\subsection{Structure from motion image based modelling (IBM)}

IBM methodology broadly follows the procedure outlined by Reitman et al. (2015), being carried out on critical outcrop sections as a tool to document key outcrop characteristics. 


\subsubsection{Outcrop IBMs}

After defining a suitable section of outcrop for IBM, a surveying tripod was set 5-10 metres back from the outcrop to document the maximum outcrop area. A Trimble D-GPS was then mounted to the tripod, and left recording positions for 10-15 minutes to define the base station position.

Labelled nails and washers (Figure 2.2) were then hammered into the outcrop at approximately $2 \mathrm{~m} \mathrm{x}$

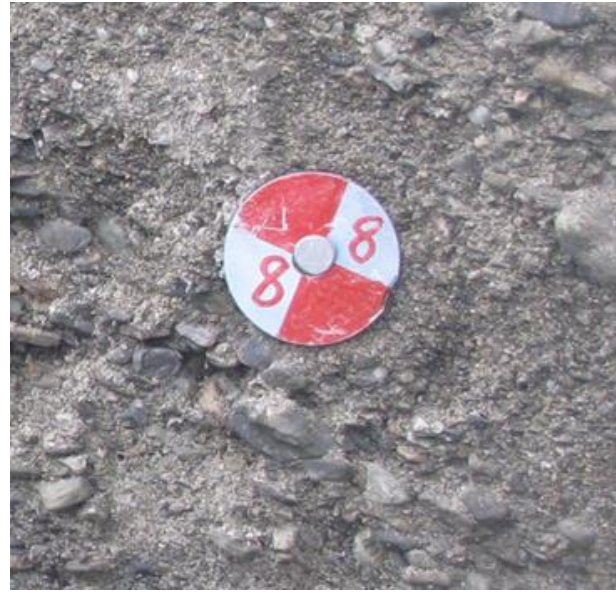

Figure 2.2 Ground control markers used for ortho-rectification. $2 \mathrm{~m}$ spacing, to be utilised as control points on the outcrop surface. The outcrop exposure was photographed in detail, ensuring sufficient $(1 / 3$ to $2 / 3)$ overlap between sequential images. For an IBM developed in this thesis, 296 images were taken in order to document an outcrop area of $\sim 79 \mathrm{~m}^{2}$, with 24 control point markers used across the outcrop.

A 30-metre tape measure and geological compass was then utilised to record an azimuth and distance to control points from the base station, as well as the elevation of control points relative to the station. Each control point was assigned a position in the New Zealand Transverse Mercator 2000 (NZTM2000) projection system using ArcGIS.

To ortho-rectify images and produce georeferenced IBM's, Agisoft PhotoScan Professional Edition v1.1 was utilised, closely following the methods of Reitman et al. (2015). IBM's produced are presently housed at Victoria University of Wellington.

\subsection{Sample Processing and Analysis}

\subsubsection{Grain-size analysis: Sandstone \& Mudstone samples}

Grain-size analysis was carried out on sand and mudstone samples using the methodology of Dunbar and Barrett (2005), with conglomerate and diamictite samples analysed using clast fabric methods (Section 2.4). Sediment samples recovered by drilling and outcrop sampling were dried in a $40{ }^{\circ} \mathrm{C}$ oven, and then disaggregated in a laboratory. Samples were dry sieved to $1400 \mu \mathrm{m}$, with the $>1400 \mu \mathrm{m}$ fraction omitted from analysis due to restrictions of the laser sizer equipment. 
Samples recovered from DFDP-2B, where visibly contaminated with CR-650 drilling mud underwent additional rinsing to remove contaminants. Samples were transferred into $50 \mathrm{~mL}$ falcon tubes containing $0.5 \mathrm{~g} / \mathrm{L}$ Calgon solution, and spun in a centrifuge at $2400 \mathrm{rpm}$ for 10 minutes. Samples were then frozen and transferred to a freeze drier until all liquid was removed (24-48 hour duration). This process resulted in the drilling mud forming a dried slag layer overlying the sediments, which could then be removed directly from the falcon tube.

While the grain-size profiles of samples from DFDP-2B, which underwent the extended rinsing process, are comparable to profiles of samples recovered in DFDP-2A, the potential for advecting and removing fine silt and clay particles is apparent. Grain-size profiles from samples recovered in DFDP-2A were used in preference to those from DFDP-2B.

For laser diffraction particle size analysis, samples were mechanically split to retain 0.1 -2 grams of sample, being the suitable volume for this method of analysis. Samples were transferred to a beaker with $0.5 \mathrm{~g} / \mathrm{L}$ Calgon solution, and furthered disaggregated in a sonic tank with a stirrer for 10-15 minutes directly prior to analysis.

Samples were then transferred to a Beckmann Coulter LP1300 for grain-size analysis, allowing grain-size distributions for the $<1400 \mu \mathrm{m}$ fraction to be obtained. Summary statistics and grain-size plots were produced using an R script, with summary datasets available in Appendix A4, and full datasets available in Digital Appendix C.

\subsubsection{Grain-size analysis: Coarse-grained samples*}

Additional grain-size analysis was carried out on coarse-grained or clast rich samples via sieve stack. Samples were sieved into $>2 \mathrm{~mm}, 2$ to $0.85 \mathrm{~mm}$ and $<0.85 \mathrm{~mm}$ size fractions, and then weighed to quantify the sample weight percentage in each volume fraction. Summary sieve stack data is available in Appendix A5.

\subsubsection{Portable X-ray Fluorescence Analysis}

\section{Operation}

Portable X-ray fluorescence (pXRF) analysis was carried out on sandstone and mudstone samples sampling using the method outlined by Fisher et al. (2014). Samples were dry sieved to $1400 \mu \mathrm{m}$, with the $>1400 \mu \mathrm{m}$ fraction being omitted from analysis. 
This was done to ensure that the bulk chemical analysis was not skewed by the presence of large particles, which may not represent the true bulk chemistry of the sample.

Sediment samples were dried in a $40{ }^{\circ} \mathrm{C}$ oven, and then manually disaggregated. Samples were then mechanically split to 15-20 gram fractions and transferred to 20gram plastic tubes used for pXRF analysis. Sample lids were removed, and a thin polypropylene film applied to cover the tube end, secured with a rubber band. Samples were then upended to sit directly on the analysing film of the pXRF unit before analysis.

Analysis of samples occurred over two sessions, an initial sample run using the Olympus Delta Professional 40kV unit, and a latter sample run using the Olympus Vanta 50 $\mathrm{kV}$ unit, using the instrument set up displayed in Figure 2.3.

As the effectiveness of pXRF units in determining bulk composition is dependent on the excitation energy beam used (in $\mathrm{kV}$ ), and the duration of sample exposure to each beam, standardisation of results between instruments and instrument settings is an important measure (Reitman et al., 2015).

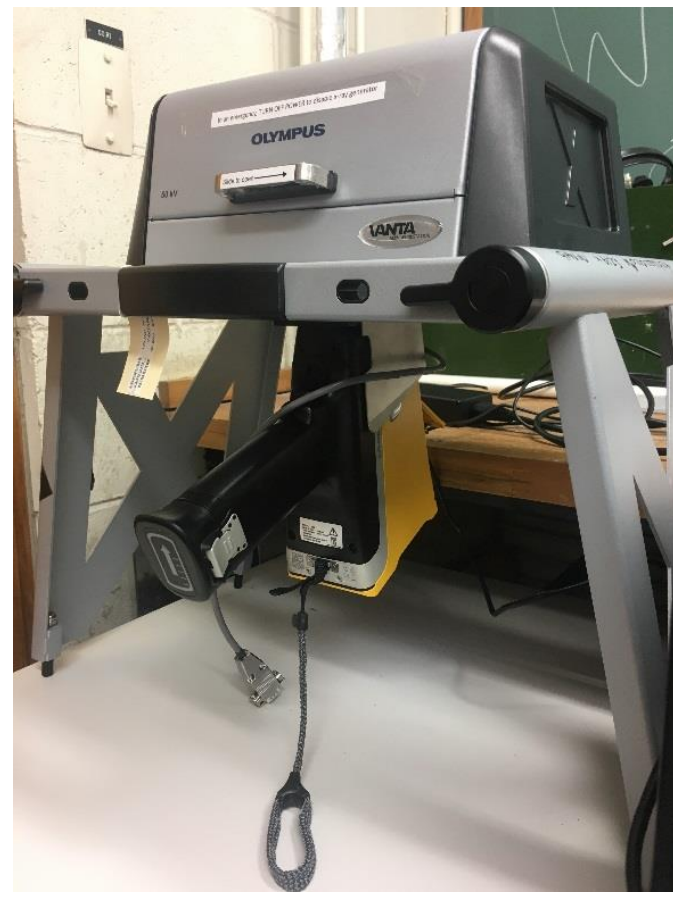

Figure 2.3 Olympus Vanta pXRF unit in operating stand (Image supplied by M. Liston).

To obtain compositional data on both major

( $\mathrm{Si}, \mathrm{Al}, \mathrm{Fe}, \mathrm{K}, \mathrm{Ca})$ and minor/trace elements ( $\mathrm{Mn}, \mathrm{Cu}, \mathrm{Sr}$, Th, $\mathrm{Rb}$ ), samples were analysed using the Delta unit operating in pre-set Soil and Geochem operating modes. Beam energy and exposure duration for operating modes can be found in Fisher et al. (2015).

Operation of the Vanta unit was carried out in a pre-set Geochem mode, operating a 40 $\mathrm{kV}$ and $10 \mathrm{kV}$ beam energy for an exposure duration of 30 seconds respectively. Additionally, samples were analysed using a $50 \mathrm{kV}$ and $10 \mathrm{kV}$ beam energy using the same exposure duration outlined above. 


\section{Standardisation}

In order to generate bulk composition datasets suitable for publication and comparison across multiple $\mathrm{pXRF}$ units, standardisation and calibration procedures are required (Gazley et al., 2011, Fisher et al., 2014). The standardisation procedure outlined below was carried out in collaboration with Dr. Michael Gazley (CSIRO).

Across both analytical sessions, the following United States Geological Survey (USGS) and Geological Survey of Japan (GSJ) powdered standards were analysed for standardisation:

\section{- USGS: AGV-2, SCO-1, COQ-1, BHVO-2, SGR-1}

- GSJ: JR-2, JG-2

Standards were transferred into 20-gram plastic tubes, using the same handling and preparation procedures outlined above. In both analytical sessions, the full standard block was analysed at the beginning of each test day, with blocks of 4 randomly selected standards being run after 20 unknowns had been analysed. A full standard block was then run at the end of each test day.

Measured concentration of elements for the standards analysed was plotted against known concentrations in ppm, in order to develop correction factors for individual elements (Table 2). This method also allowed the analytical accuracy of pXRF units for specific elements to be evaluated.

Table 2 Correction factors for elements of interest across varying operating modes and base pXRF units. Element correction applied with element concentrations in ppm.

\begin{tabular}{|l|l|l|}
\hline Element & Operating mode & Sample correction factor \\
\hline $\mathrm{Fe}$ & Geochem (Delta) & $\mathrm{y}=1.0161 \mathrm{x}+0 \mathrm{R}^{2}=0.9914$ \\
\hline $\mathrm{Al}$ & Geochem (Vanta) & $\mathrm{y}=0.9599 \mathrm{x}+0 \mathrm{R}^{2}=0.9817$ \\
\hline $\mathrm{Si}$ & Geochem (Delta) & $\mathrm{y}=0.7395 \mathrm{x}+6402.51 \mathrm{R}^{2}=0.8824$ \\
\hline $\mathrm{K}$ & Geochem (Vanta) & $\mathrm{y}=1.0622 \mathrm{x}+0 \mathrm{R}^{2}=0.9659$ \\
\hline $\mathrm{Ca}$ & Geochem (Delta) & $\mathrm{y}=0.9662 \mathrm{x}+0 \mathrm{R}^{2}=0.9315$ \\
\hline & Geochem (Vanta) & $\mathrm{y}=0.9670 \mathrm{x}+0 \mathrm{R}^{2}=0.9725$ \\
\hline & Geochem (Delta) & $\mathrm{y}=1.145 \mathrm{x}+0 \mathrm{R}^{2}=0.9556$ \\
\hline $\mathrm{Mn}$ & Geochem (Vanta) & $\mathrm{y}=0.9267 \mathrm{x}+0 \mathrm{R}^{2}=0.9750$ \\
\hline $\mathrm{Sr}$ & Geochem (Delta) & $\mathrm{y}=1.0354 \mathrm{x}+0 \mathrm{R}^{2}=0.9921$ \\
\hline Geochem (Vanta) & $\mathrm{y}=1.012 \mathrm{x}+0 \mathrm{R}^{2}=0.9984$ \\
\hline & Soil (Delta) & $\mathrm{y}=0.8150+0 \mathrm{R}^{2}=0.9693$ \\
\hline & Geochem (Vanta) & $\mathrm{y}=0.8593 \mathrm{x}+121.2 \mathrm{R}^{2}=.9922$ \\
\hline & Soil (Delta) & $\mathrm{y}=1.1467 \mathrm{x}+0 \mathrm{R}^{2}=0.9898$ \\
\hline & Geochem 50kV (Vanta) & $\mathrm{y}=1.1774 \mathrm{x}+0 \mathrm{R}^{2}=0.9887$ \\
\hline
\end{tabular}




\subsection{Clast shape analysis}

Clast shape can be expressed through three related yet independent variables: form, roundness and surface texture. Shape analysis was undertaken based on methods outlined in Atkins (2003) after Barrett (1980) and Benn and Ballantyne (1993). Each variable was determined individually for singular clasts, as discussed below.

\subsubsection{Form}

Form represents the overall geometric shape of a clast (Barrett, 1980). Clast form is described by measurement of the three orthogonal axes of a clast, being the long (a), intermediate (b) and short (c) axes. These measurements allow clast form to be expressed in relation to three basic endmember shapes: Blocks (spheres), Slabs (disks) and Elongate (rods), and plotted on ternary diagrams developed by Benn and Ballantyne (1993) (Figure 2.4).

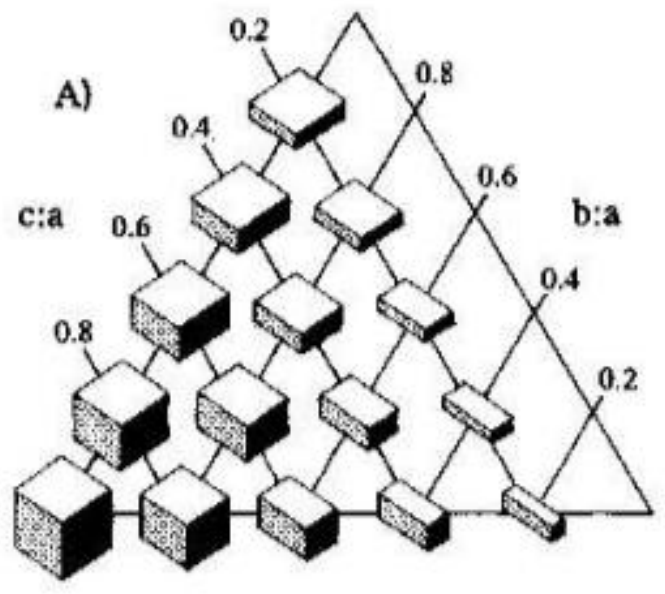

Figure 2.4 Ternary diagram plotting end-member clast shapes using a,b,c axes (Benn and Ballantyne, 1993).

Orthogonal axes were measured on individual clasts with a axes between 20 and 70 $\mathrm{mm}$, and plotted on ternary diagrams in the format of Figure 2.4. Summary clast shape data is presented in Appendix A3.

\subsubsection{Roundness}

Clast roundness was estimated using the visual comparison chart of Krumbein (1941), on clasts with a axes between 20 and $70 \mathrm{~mm}$. Roundness estimations for samples were used to produce bar charts of percent frequency of clasts in each roundness category. Krumbein roundness were converted to Powers (1953) roundness categories using the following conversion: very angular 0.0-0.17; angular 0.17-0.25; sub-angular 0.25-0.35; sub-rounded 0.35-0.49; rounded 0.49-0.70; well-rounded 0.70-1.0.

\subsubsection{Surface texture}

Clast surface texture was examined to identify characteristic markings on clast surfaces, which have formed via contact with other rocks. Where present, these features can be 
related to clast transport processes (Barrett, 1980, Atkins, 2003). Cm-scale surface features including pits and striations on clasts were identified and examined by eye, and measured using a ruler. Clasts showing striae were also examined using a reflected light microscope, to identify and measure micro-scale features. The relative depth, length, abundance and orientation of surface features were also noted.

\subsubsection{RA-C 40 diagram}

RA-C 40 diagrams were produced and overlain with transport fields constrained by published data of Benn and Ballantyne (1993), following the method of Atkins (2003). This method uses clast form measurements to determine the most probable method of glacial transport, and has been shown to provide excellent differentiation between active and passively transported clasts (Atkins, 2003, Benn and Ballantyne, 1993).

\subsection{Radiocarbon dating*}

Wood and leaf samples were sieved from drill cuttings in the upper $~ 230$ metres MD of boreholes DFDP-2A and DFDP-2B. Macrofossils cleaned of residual sediment were treated with a standard AAA (acid-alkali-acid) pre-treatment procedure performed to remove carbonates, fulvic compounds and humic compounds. The pre-treated wood and leaf was converted to $\mathrm{CO} 2$ by combustion, graphitised and measured by Accelerator Mass Spectrometry (AMS) according to the methods of Baisden et al. (2013) at Rafter Radiocarbon Laboratory.

The radiocarbon dates were calibrated with the SHCal13 calibration curve 34 and integrated with borehole depth using the P_Sequence prior model with a variable event thickness constant $\mathrm{k}$ in OxCal 4.2 to produce an age depth model (Ramsey, 2008, Ramsey and Lee, 2013). The age model was used to derive the duration over which the sedimentary sequence accumulated, as well as sedimentation rates (m.yr-1). Raw ${ }^{14} \mathrm{C}$ ages are presented in Appendix A1. 


\section{Chapter 3 Outcrop and Modern analogues}

This chapter presents results from field study in the Westland region. Outcrop exposures interpreted as glacio-lacustrine or glacio-fluvial are analysed, with key facies identified and facies interpretations developed. As exposures are not comprehensive in representing all glacio-lacustrine and glacio-fluvial depositional environments, key facies are also identified from published research. These facies are integrated with those identified from outcrop exposures to build two facies schemes and depositional models for glacio-lacustrine sedimentation.

Sedimentary sequences identified have implications for the depositional history of the respective catchments, therefore a detailed analysis of lithological units is presented.

\subsection{Waitangitaona River Sections}

The Waitangitaona River is situated 5 kilometres west of the Whataroa Township and $\sim 8.5$ kilometres southwest of the DFDP-2 drill-site. Fed by three sub-parallel creeks (Purcell, Darnley and Gaunt), the Waitangitaona River drains the Price Range, the first major range east of the Alpine Fault. The DFDP-1 drill-site is located 2 kilometres southeast of the field sites, at the Alpine Fault exposure in Gaunt Creek.

The geology of the Waitangitaona catchment is dominated by high grade Alpine Schist, with a thin band of mylonite proximal to the Alpine Fault (Figure 3.1). Westwards of the Alpine Fault, the Waitangitaona River is bordered by mid-late Pleistocene moraine material, outwash sediments and Western province basement (Cox and Barrell, 2007).

Field investigation in the area between the Waitangitaona road bridge ( $\mathrm{SH}$ 6) and the Waitangitaona River-Darnley Creek confluence revealed numerous sedimentary sequences, inferred to be glacio-lacustrine in origin. Outcrop exposures of key lithological units are not laterally continuous for more than 10-50 metres and are 
grouped spatially into two key sections. These sections are termed the lower and upper Waitangitaona sections (Figure 3.1).

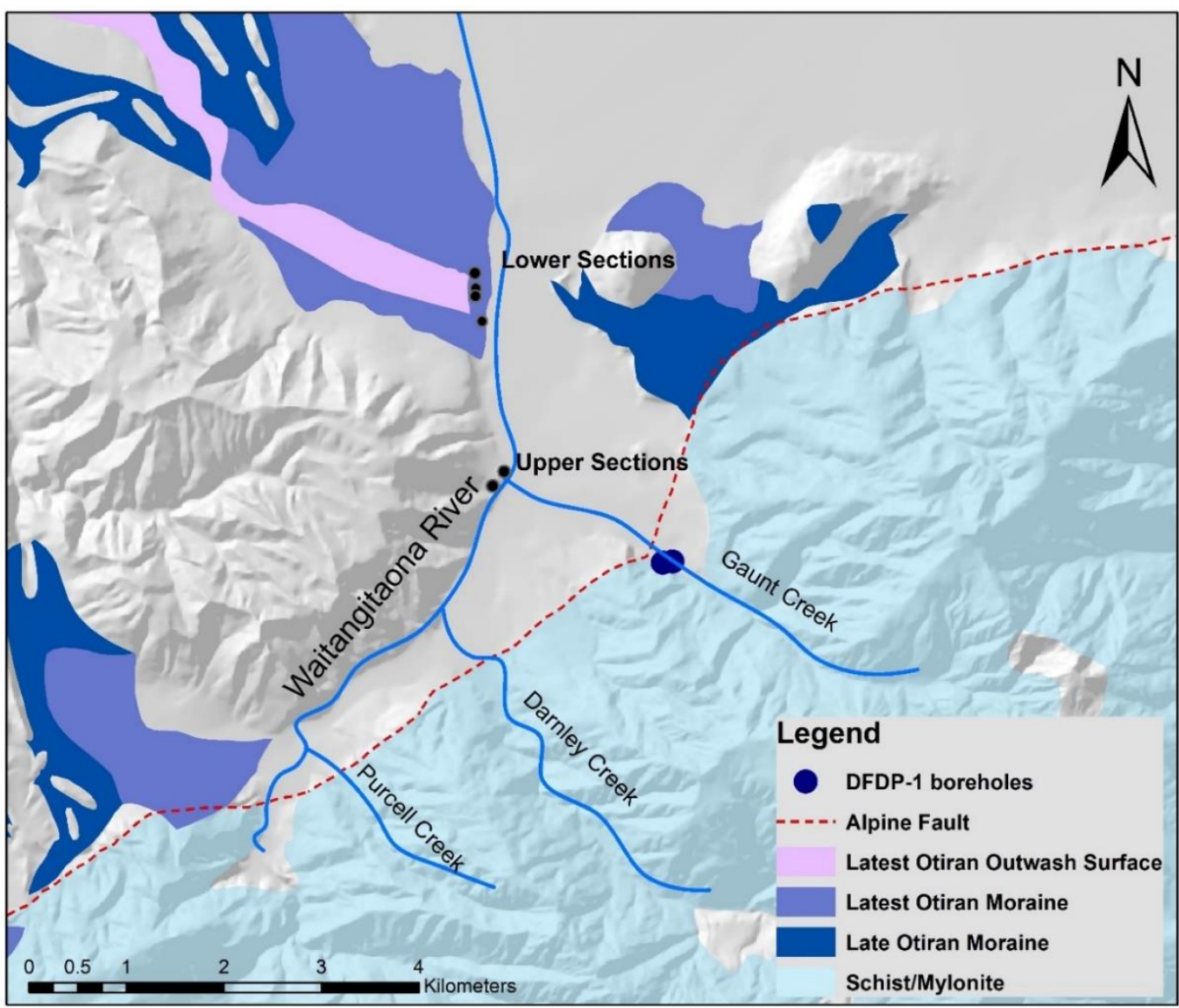

Figure 3.1 Geology of the area surrounding the Waitangitaona River, with key field sites identified. Moraines and outwash surface mapped by Barrell et al. (2013). Schist, mylonite bedrock, and Alpine Fault mapped by Cox and Barrell (2007). Unshaded areas consist undifferentiated basement and Quaternary sediments.

\subsubsection{Lower Waitangitaona sections}

Four outcrop exposures (termed Waitan 3-6) of the same stratigraphic unit are identified over a 500-metre area of the Waitangitaona River, collectively termed the lower Waitangitaona sections (Table 3). The key unit identified is a finely laminated and ripple bedded siltstone, containing sparse angular lonestone clasts (Figure 3.2). Outcrop exposures are laterally discontinuous, however have similar elevations, and are confidently correlated between sites (Table 3 ).

Table 3 Outcrops grouped as lower Waitangitaona field sites, with outcrop thickness, lateral continuity and elevation.

\begin{tabular}{|c|c|c|c|c|}
\hline Site Name & Position (NZTM) & $\begin{array}{l}\text { Estimated minimum } \\
\text { outcrop thickness }(\mathrm{m})\end{array}$ & $\begin{array}{l}\text { Observed lateral continuity } \\
\text { (m) }\end{array}$ & $\begin{array}{l}\text { Elevation (base of visible } \\
\text { section, M.A.S.L) }\end{array}$ \\
\hline Waitan 3 & $\begin{array}{l}\text { E1381180 } \\
\text { N5203417 }\end{array}$ & 4.3 & 4 & 83.2 \\
\hline Waitan 4 & $\begin{array}{l}\text { E1381195 } \\
\text { N5203246 }\end{array}$ & 0.6 & 2 & 84.8 \\
\hline Waitan 5 & $\begin{array}{l}\text { E1381198 } \\
\text { N5203181 }\end{array}$ & 1.7 & 10 & 85.3 \\
\hline Waitan 6 & $\begin{array}{l}\text { E1381277 } \\
\text { N5202894 }\end{array}$ & 9.6 & 8 & 88.3 \\
\hline
\end{tabular}




\section{Stratigraphic position}

Outcrop exposures Waitan 3-6 are sharply overlain by loosely compacted, coarsegrained conglomerate and diamictite deposits ranging significantly in thickness, and from massive to well-bedded. These exposures are not included as part of any mapped sedimentary sequence, and therefore the age is not well constrained. Exposures are mapped alongside a latest Otiran outwash surface and bordered by a latest Otiran (M5/M6) moraine mapped by Barrell et al. (2013) however (Figure 3.1).

\section{Image Log}
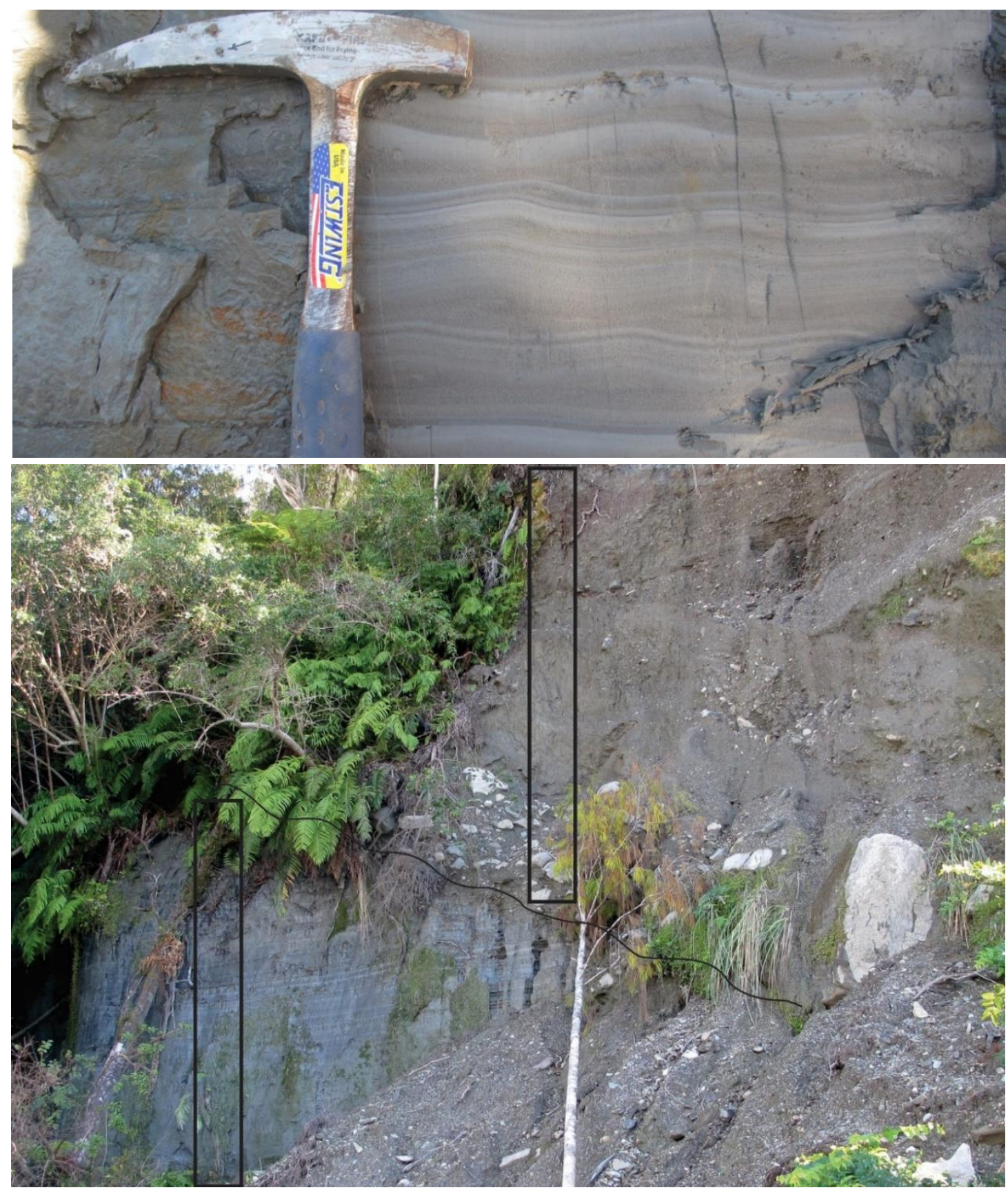

Figure 3.2 Top Image: Laminated siltstone unit exposure (Waitan-3 site). Bottom Image: Composite measured section through Waitan-6. Sharp contact between laminated siltstone and overlying unit (Grey). Measured section (black). Total height of visible section is $\sim 8$ metres. 


\section{Section Log}

The outcrop exposure at Waitan-6 (Figure 3.2, bottom image) shows the unconformable relationship between the laminated siltstone unit and overlying diamictite and conglomerate units. A measured section at field site Waitan-6 is presented in Figure 3.3.

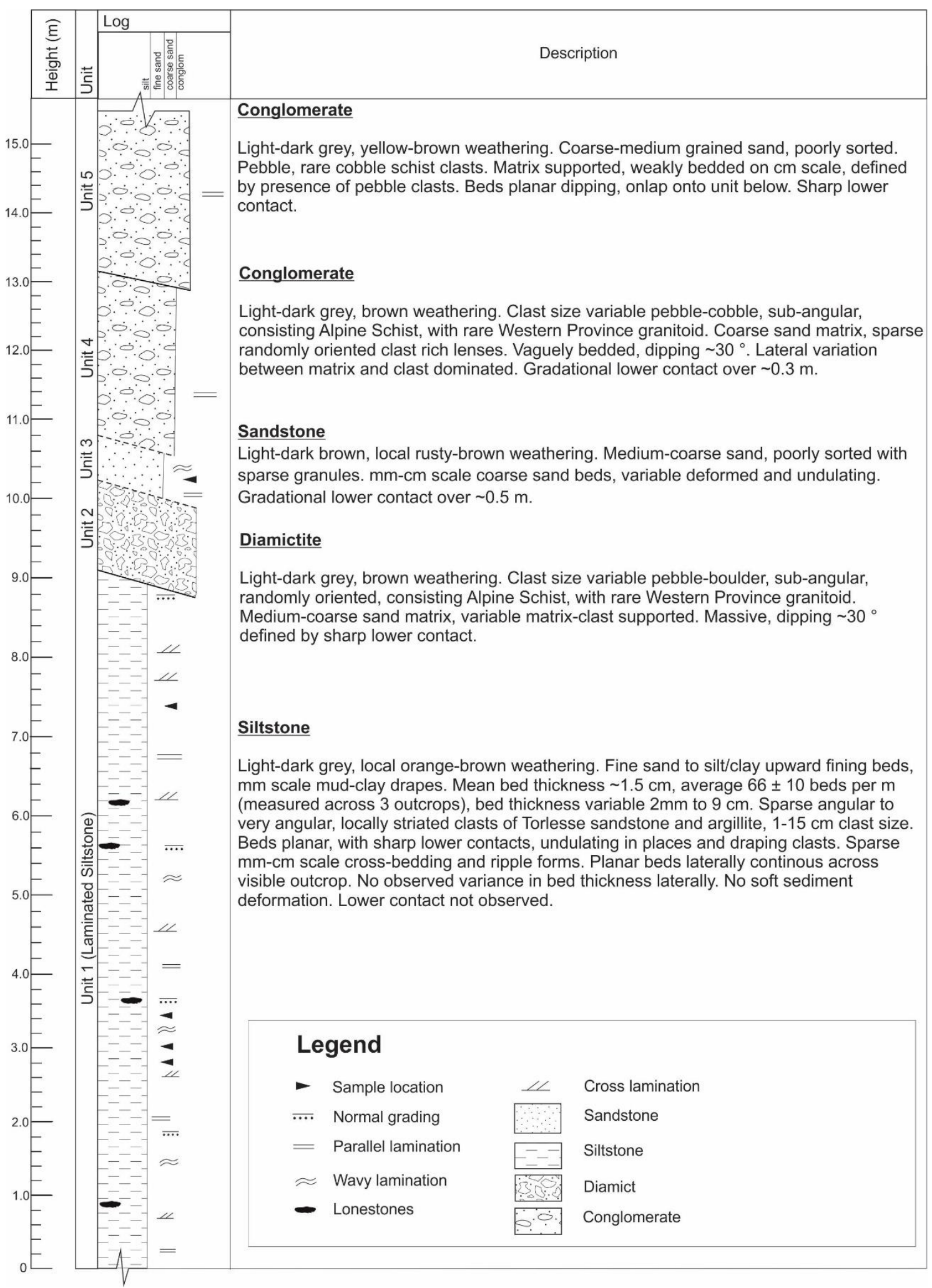

Figure 3.3 Measured section for field locality Waitan-6. Key laminated siltstone unit defined as unit 1. 


\section{Results}

This section presents results from analysis of the laminated siltstone unit described in Figure 3.3. Overlying units are not discussed further in this section.

\section{Grain-size analysis}

Laser particle size analysis was carried out on discrete beds in the laminated siltstone unit. Laminated beds are shown to consistently upward fine (Figure 3.4, top image), varying from $0.5-6 \mathrm{~cm}$ bed thickness. For grain-size comparison, a suspended sediment sample was taken from the Waiho River, South Westland, approximately 4 kilometres from the terminus of Franz Josef Glacier (Figure 3.4, bottom image). The grain-size profile displays a striking similarity to a bulk sample taken from field site Waitan-6.

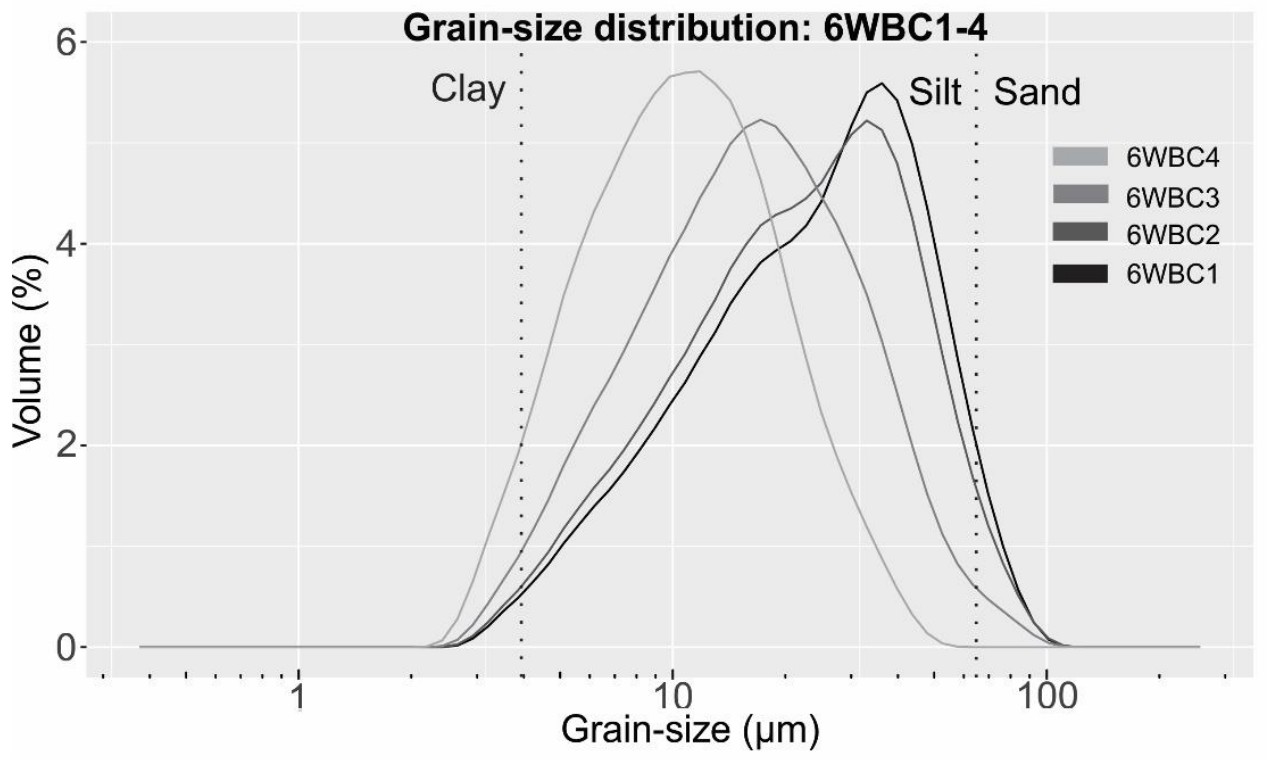

$6 \cdot$

Grain-size distribution: Bulk Sample

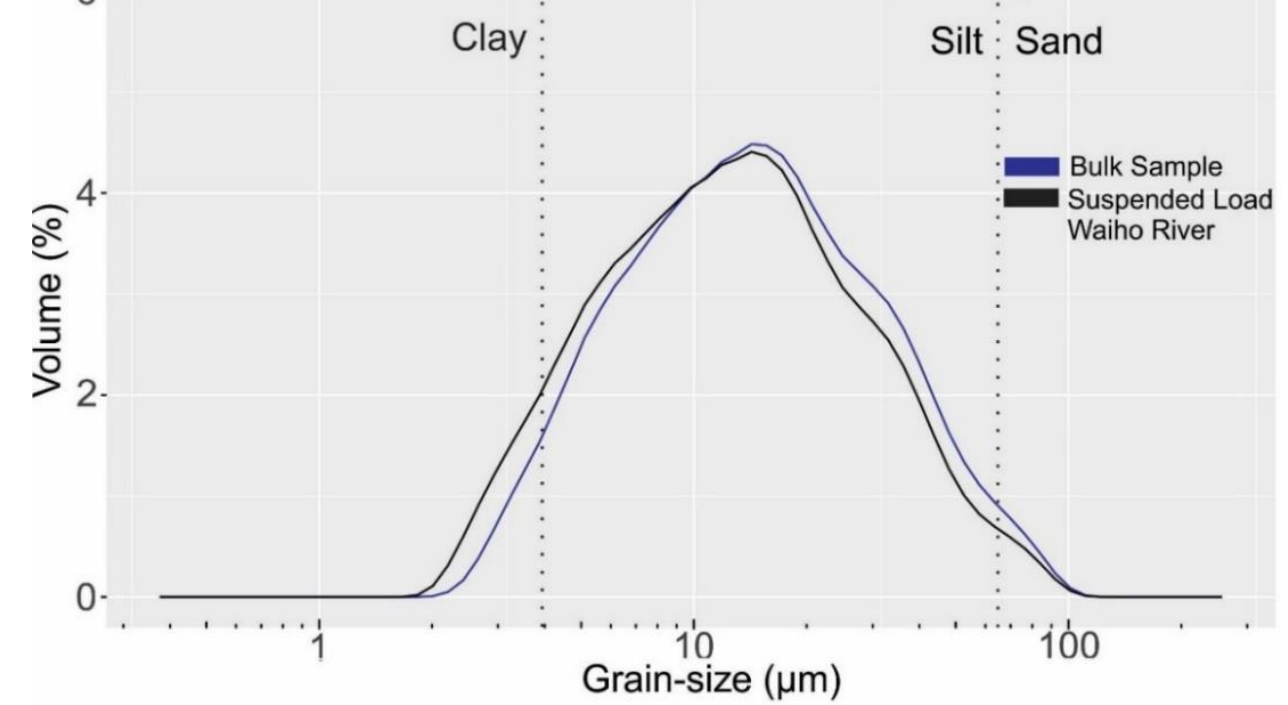

Figure 3.4 Grain-size profile through a $\sim 4 \mathrm{~cm}$ upward fining bed, sample $6 \mathrm{WBC} 1=$ base, $6 \mathrm{WBC} 4=$ top (Top image). Grain-size profile from bulk sample of Waitan-6 laminated siltstone (bottom) plotted against grain-size of suspended load, Waiho River. Full grain-size datasets available in Digital Appendix C. 


\section{Clast shape analysis}

Lonestone clasts from the laminated siltstone unit (Figure 3.5) were collected for clast shape analysis, the results of which are presented below.

Clast form analysis shows the majority of clasts have a slab-elongate morphology, with a mean C/A ratio of 0.19 (Figure 3.6). There is no clear relationship between lithology and clast form based on plots produced below. Krumbein roundness analysis shows all clasts collected to be very angular to angular in morphology. No sub-rounded to rounded clasts were observed in any of the lower Waitangitaona section outcrops.
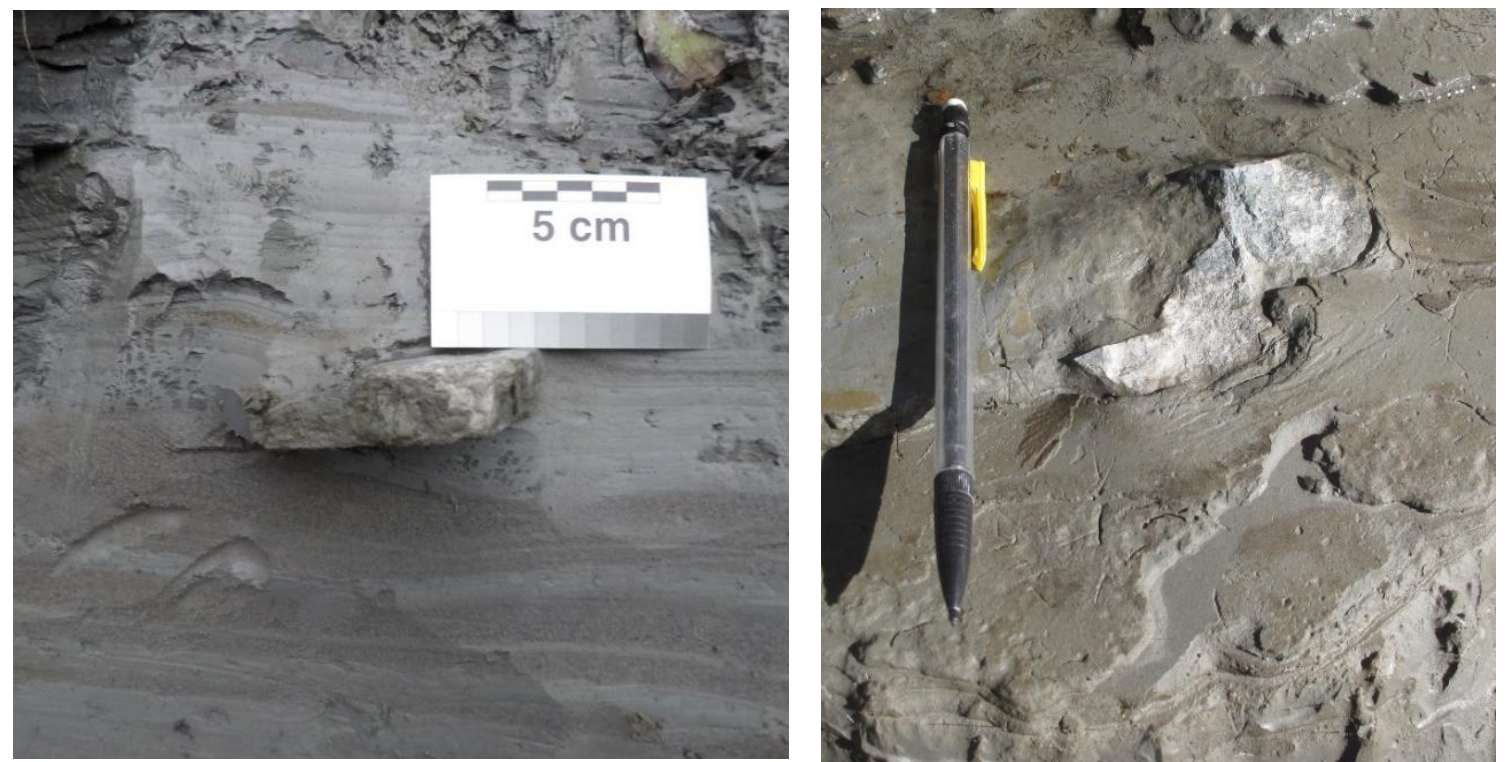

Figure 3.5 Field images of lonestone clasts from outcrop exposures of the laminated siltstone unit at lower Waitangitaona sections.

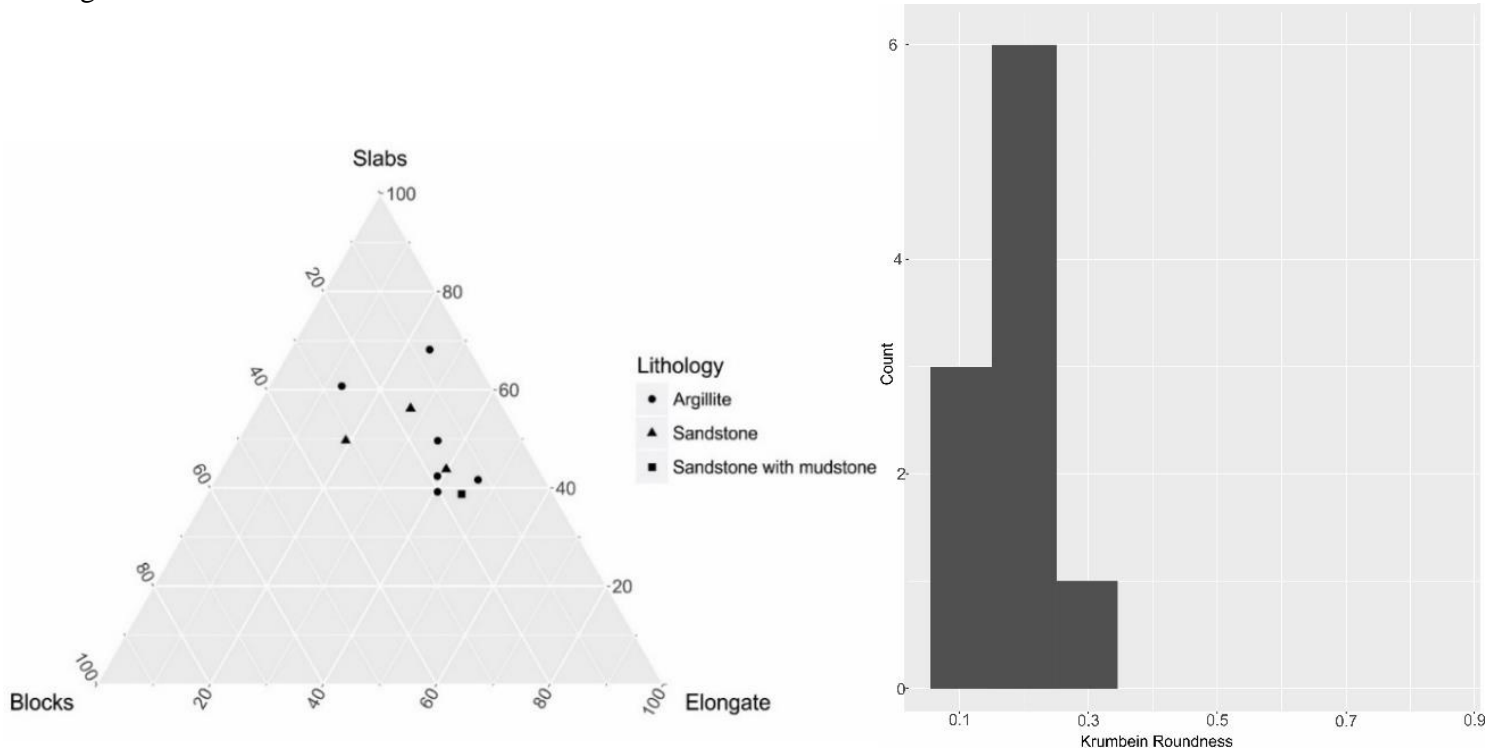

Figure 3.6 Clast form ternary (Left) and Krumbein roundness histogram (Right) for clasts sampled from laminated siltstone unit at field site Waitan-6. Ternary plot produced based on methods of Benn and Ballantyne (1993). Summary data available in Appendix A3. 


\section{Surface texture}

Lonestones from the laminated siltstone unit were analysed to evaluate clast surface texture. Eight of ten clasts collected preserve surface striations, with the majority showing common shallow crosscutting striae (Figure 3.7, top right image). Crosscutting striae are comparable to those documented by Atkins (2003), formed during transport down a scree slope. Addition to this, two clasts display deeper, parallel or parallel striations (Figure 3.7, top left, middle left images) on clast surfaces, comparable to those formed by sub-glacial processes (Atkins, 2003).
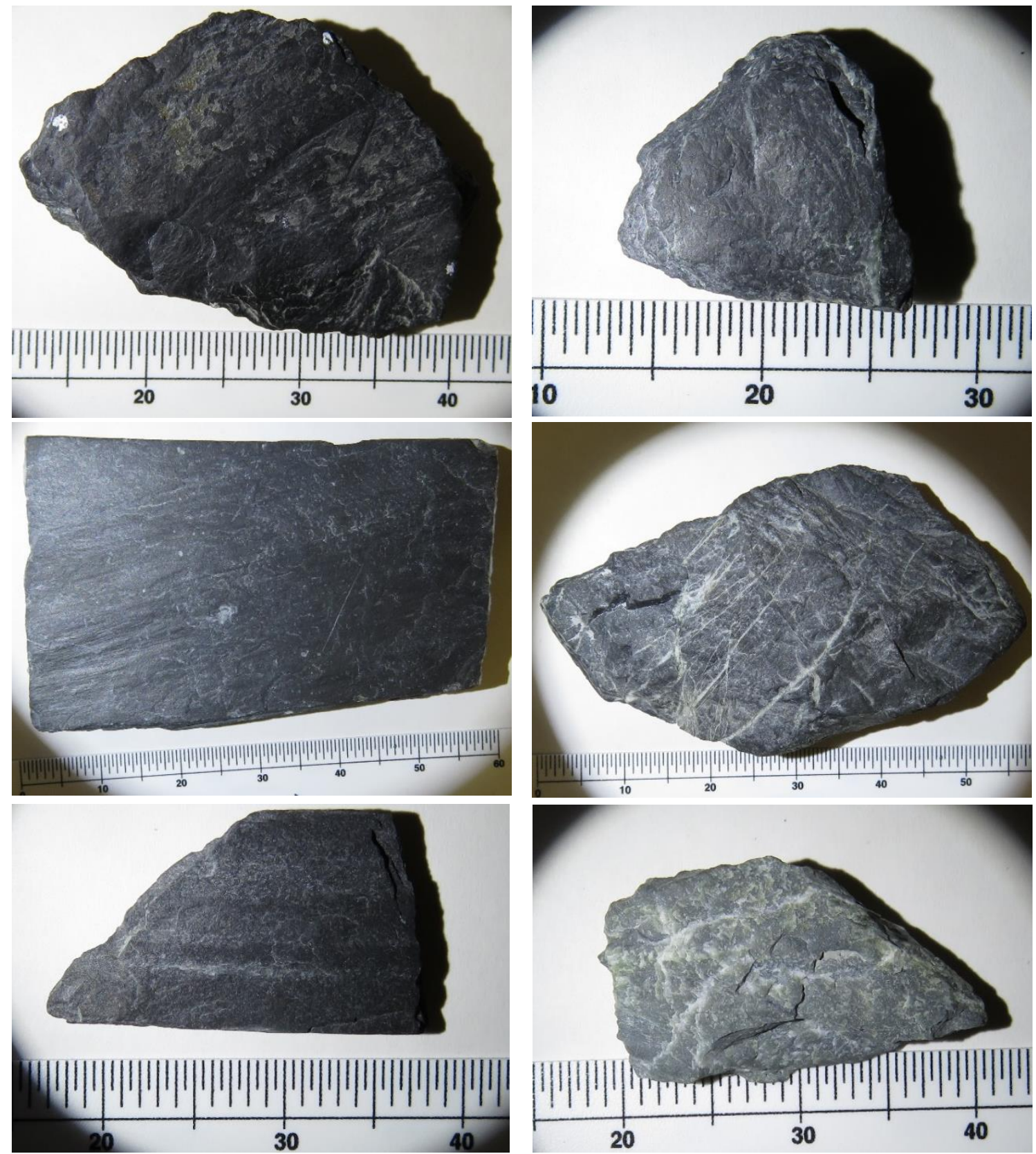

Figure 3.7 Images of lonestone clasts collected from Waitan-6 field sites. Top left, middle left clasts show subparallel striations, Top right, middle right show shallow cross-cutting striations. Bottom left, bottom right show no striations. Scale in mm. Additional images are available in Digital Appendix C. 


\section{Clast lithology}

As West Coast catchments drain bedrock of variable metamorphic grade, the lithology of clasts can be used as a provenance tool. Analysis of clasts sampled from the laminated siltstone unit shows that six of ten clasts are derived from argillite bedrock, with four derived from low-grade Torlesse sandstone. Bedrock exposures of low grade sandstones and argillites outcrop proximal to the Main Divide, but do not outcrop in the present day Waitangitaona catchment (Figure 3.8) (Cox and Barrell, 2007).

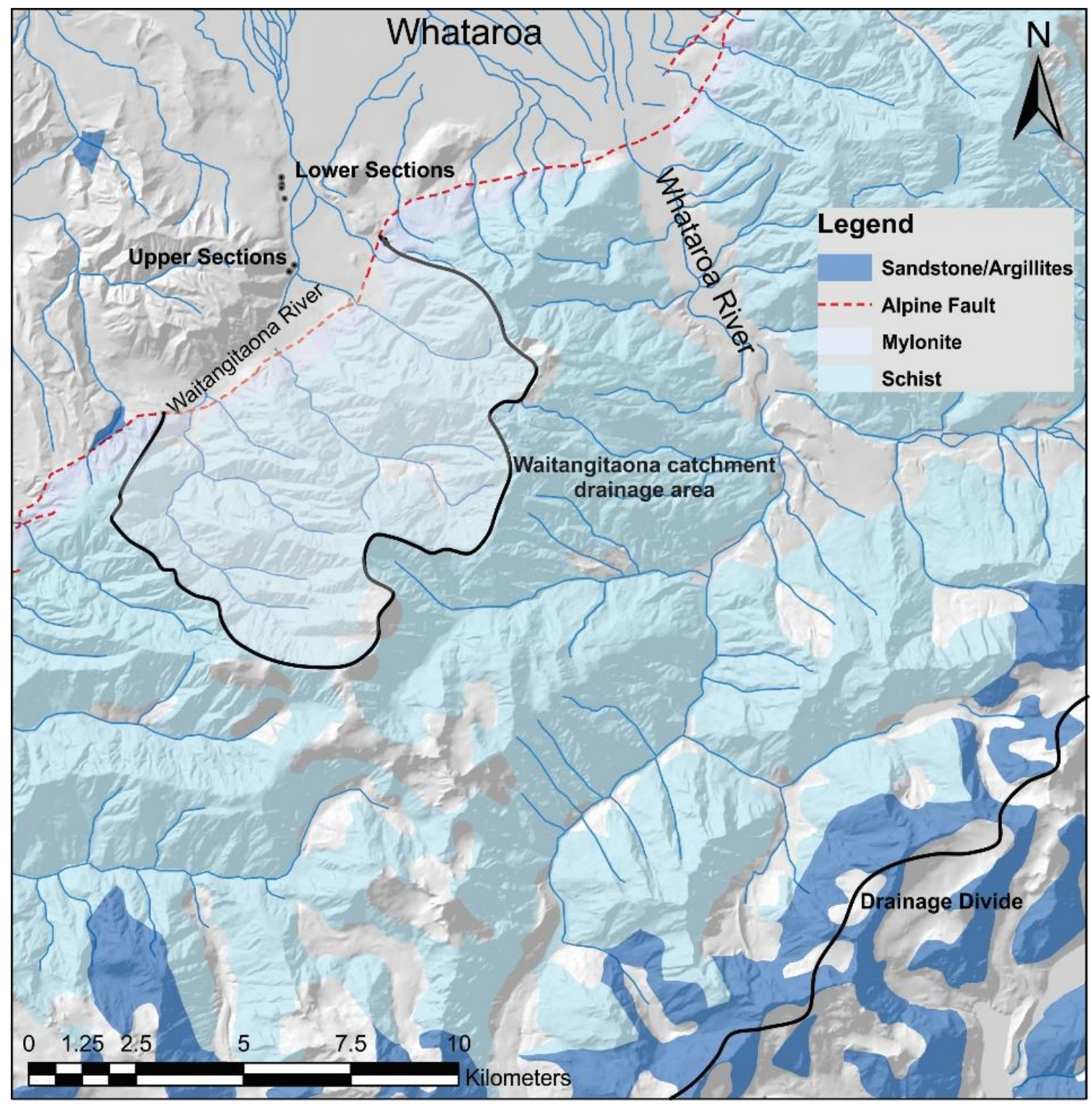

Figure 3.8 Sandstone/Argillite and Schist bedrock in the Whataroa/Waitangitaona catchments. Waitangitaona catchment solely drains schist, mylonite bedrock. Whataroa catchment drains schist, sandstones/argillites at the head of the catchment proximal to the main drainage divide (Black). Bedrock lithology, Alpine Fault trace mapped by Cox and Barrell (2007). Unshaded areas represent Western Province basement, Quaternary alluvial and glacial material, and modern ice cover. 


\subsubsection{Key facies}

From the laminated siltstone unit at the lower Waitangitaona section outcrops, three key facies were recognised and facies associations identified (Table 4, Figure 3.9). These key facies are utilised in later developing a facies scheme and depositional model. Facies codes are based on the terminology of Eyles et al. (1983).

Table 4 Key facies identified from the laminated siltstone unit at the lower Waitangitaona field sites.

\begin{tabular}{|lllll|}
\hline Particle Grade & Facies code & Lithofacies & Bedding/Sedimentary Structures & Facies association \\
\hline Fine sand-clay & Fl & $\begin{array}{l}\text { Dark-light grey, coarse Normally graded bedding, } 5-80 \mathrm{~mm} \\
\text { to fine laminated silts } \\
\text { with rare clasts } \\
\text { thickness }\end{array}$ & $\begin{array}{l}\text { Overlies facies Flr, Fmd. } \\
\text { Typically }>10 \mathrm{Fl} \text { facies per Flr }\end{array}$ \\
& Flr & $\begin{array}{l}\text { Dark-light grey, coarse Climbing ripples, cross beds, mud drapes, } \\
\text { silts with x-lamination }\end{array}$ & 10-200 mm beds & Overlies facies Fl, Fmd,. \\
& Fmd & $\begin{array}{l}\text { Light grey, fine silt to } \\
\text { clay }\end{array}$ & $1-5 \mathrm{~mm}$, draping ripple bedforms of Flr & Drapes Fl, Flr facies \\
\hline
\end{tabular}
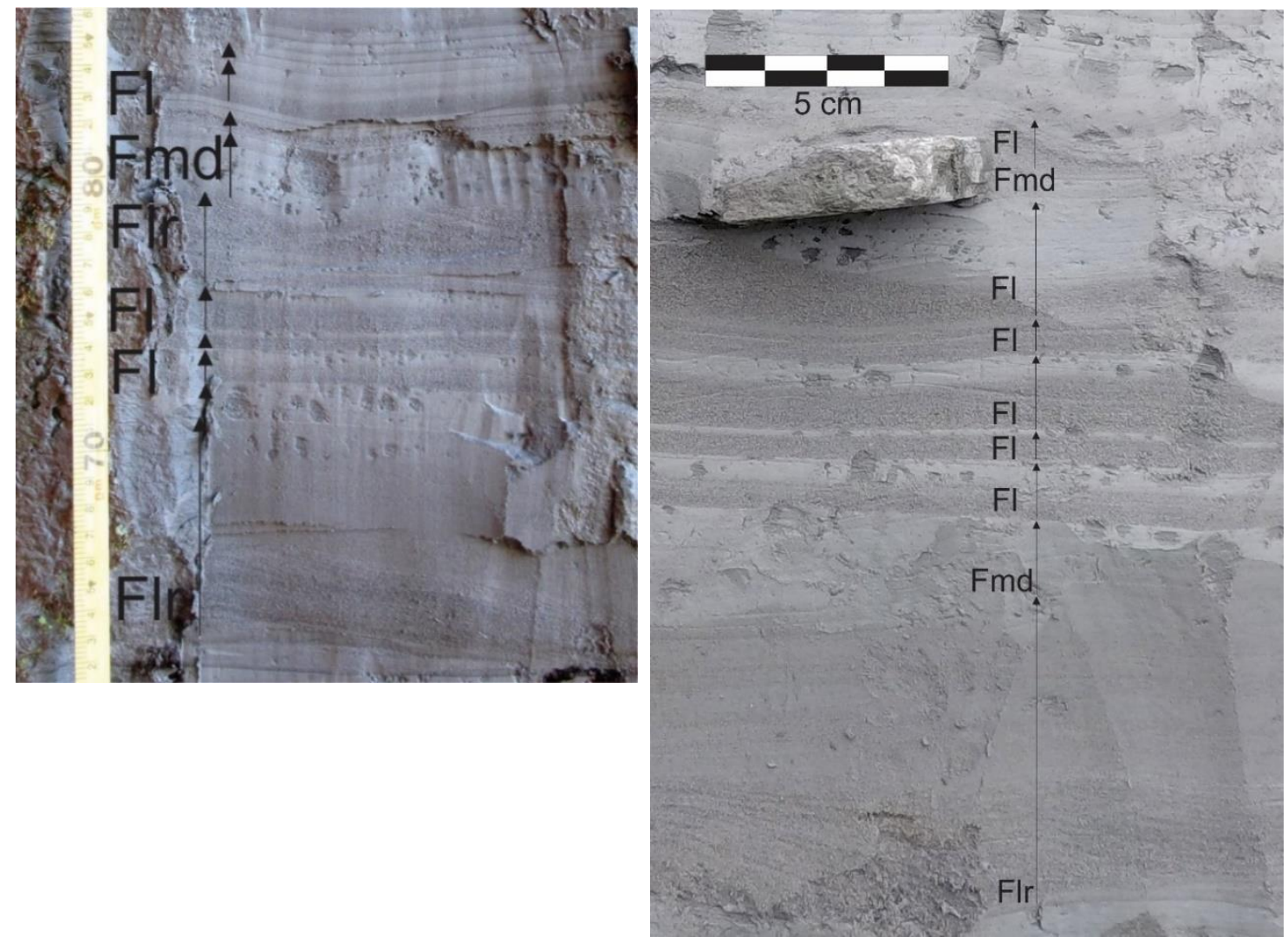

Figure 3.9 Annotated field images from lower Waitangitaona field sites with key facies identified from the laminated siltstone unit. 


\subsubsection{Upper Waitangitaona sections}

Two exposures of key lithological units are identified in a complex series of outcrops grouped as the upper Waitangitaona sections (Table 5).

Table 5 Outcrop exposures for upper Waitangitaona field sites, with estimated outcrop thickness, lateral continuity and base elevations.

\begin{tabular}{|c|c|c|c|c|}
\hline Site Name & Position (NZTM) & $\begin{array}{l}\text { Estimated minimum outcrop } \\
\text { thickness }(\mathrm{m})\end{array}$ & $\begin{array}{l}\text { Observed lateral continuity } \\
(\mathrm{m})\end{array}$ & $\begin{array}{l}\text { Elevation (base of visible } \\
\text { section, M.A.S.L) }\end{array}$ \\
\hline Waitan 9 & $\begin{array}{l}\text { E1381554 } \\
\text { N5201512 }\end{array}$ & 4.3 & 3 & 110.5 \\
\hline Waitan 12 & $\begin{array}{l}\text { E1381475 } \\
\text { N5201357 }\end{array}$ & 8 & 10 & $\sim 105$ \\
\hline
\end{tabular}

Results from field site Waitan-12 are considered supplementary to this chapter and are included in Appendix B3, rather than presented here.

\section{Field site Waitan-9}

The gross lithology of the unit identified at field site Waitan-9 is a finely laminated siltstone with sparse lonestone clasts. As only 4.5 metres of outcrop was exposed at the field site, a section was not measured, however the outcrop was logged in the field (Figure 3.10).

Field observations noted this unit to display comparable bed thickness and architecture to the laminated siltstone unit at the lower Waitangitaona sections. The laminated siltstone unit at the Waitan-9 site was noted to be more sand rich, in contrast to the siltdominated beds at the lower Waitangitaona sections however.

\section{Stratigraphic position}

The laminated siltstone unit at field site Waitan- 9 is situated in a region mapped by Barrell et al. (2013) as undifferentiated Quaternary deposits mantled onto Western Province basement, with no additional age determinations made. Field evidence shows the unit overlain by a coarse boulder diamict, inferred to be glacial in origin. This observation requires the laminated siltstone unit to be late Otiran or older, deposited prior to latest Otiran glacial advance. This laminated siltstone unit sits at a higher elevation, and likely stratigraphically above the mapped extent of the laminated unit at lower Waitangitaona sections, and therefore the units are not inferred to be correlative. 


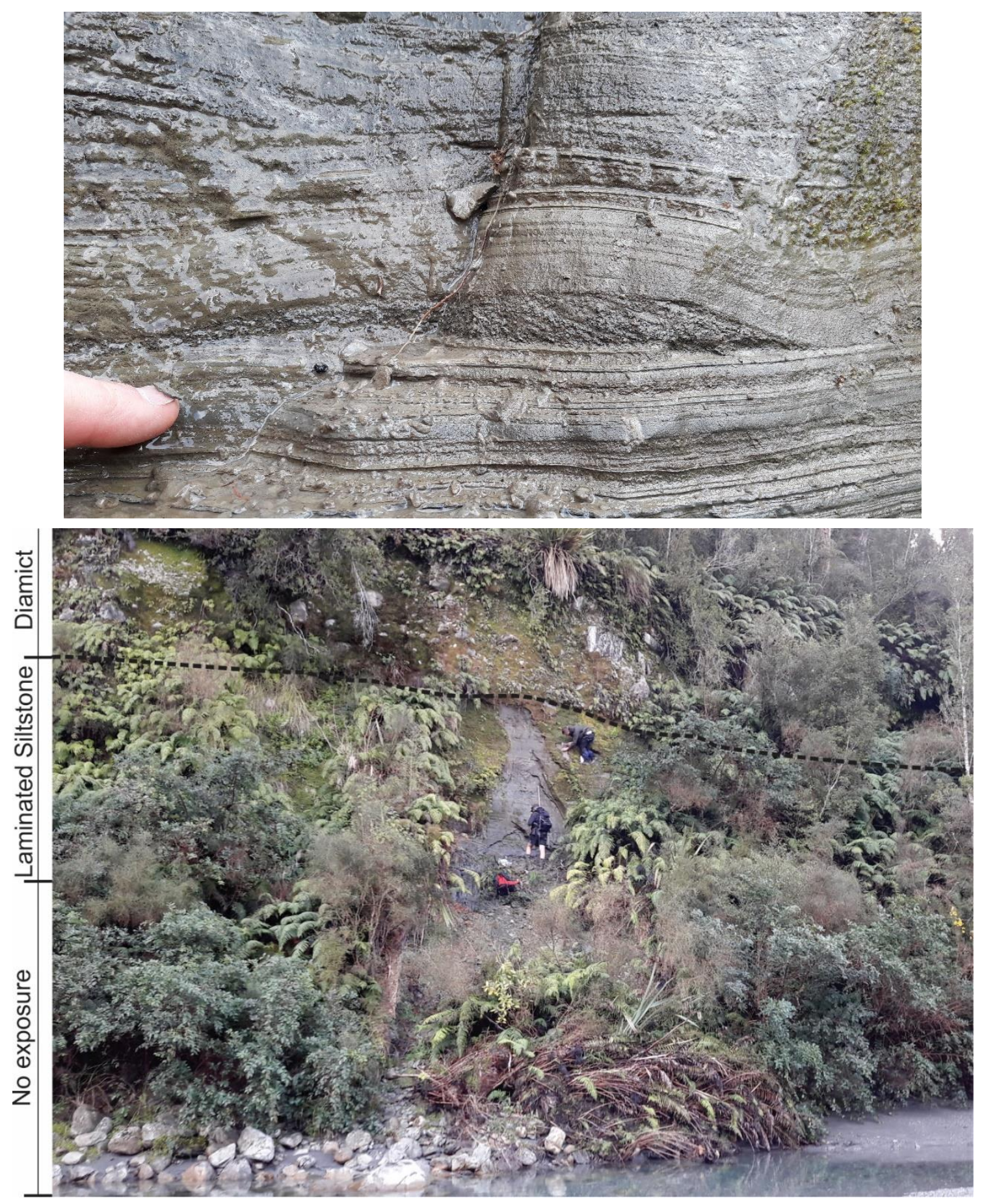

Figure 3.10 Top image: :aminated siltstone unit at field site Waitan-9 unit showing laminations and cross bedding. Bottom image: Annotated image of field site Waitan-9, with laminated siltstone unit identified, and upper contact with overlying diamict marked (black dotted line).

\section{Results}

This section presents results from the analysis of the laminated siltstone unit at field site Waitan-9 (Figure 3.10). 


\section{Grain-size analysis}

Bulk samples, representing the integration of multiple discrete beds were taken at $\sim 1.5$ metre intervals through the visible outcrop. Field observations noted a general upward coarsening trend through the outcrop, with a prevalence of coarser ripple bedded layers up-section.

Grain-size trends support field observations, with bulk samples displaying an overall upward coarsening trend, from a mean grain-size of $19 \mu \mathrm{m}$ at the section base, to $32 \mu \mathrm{m}$ at the upper contact (Figure 3.11). Grain-size profiles show bi-modal trends, consistent with bulk samples analysed in this study. An increase in sample standard deviation is also noted up-section.

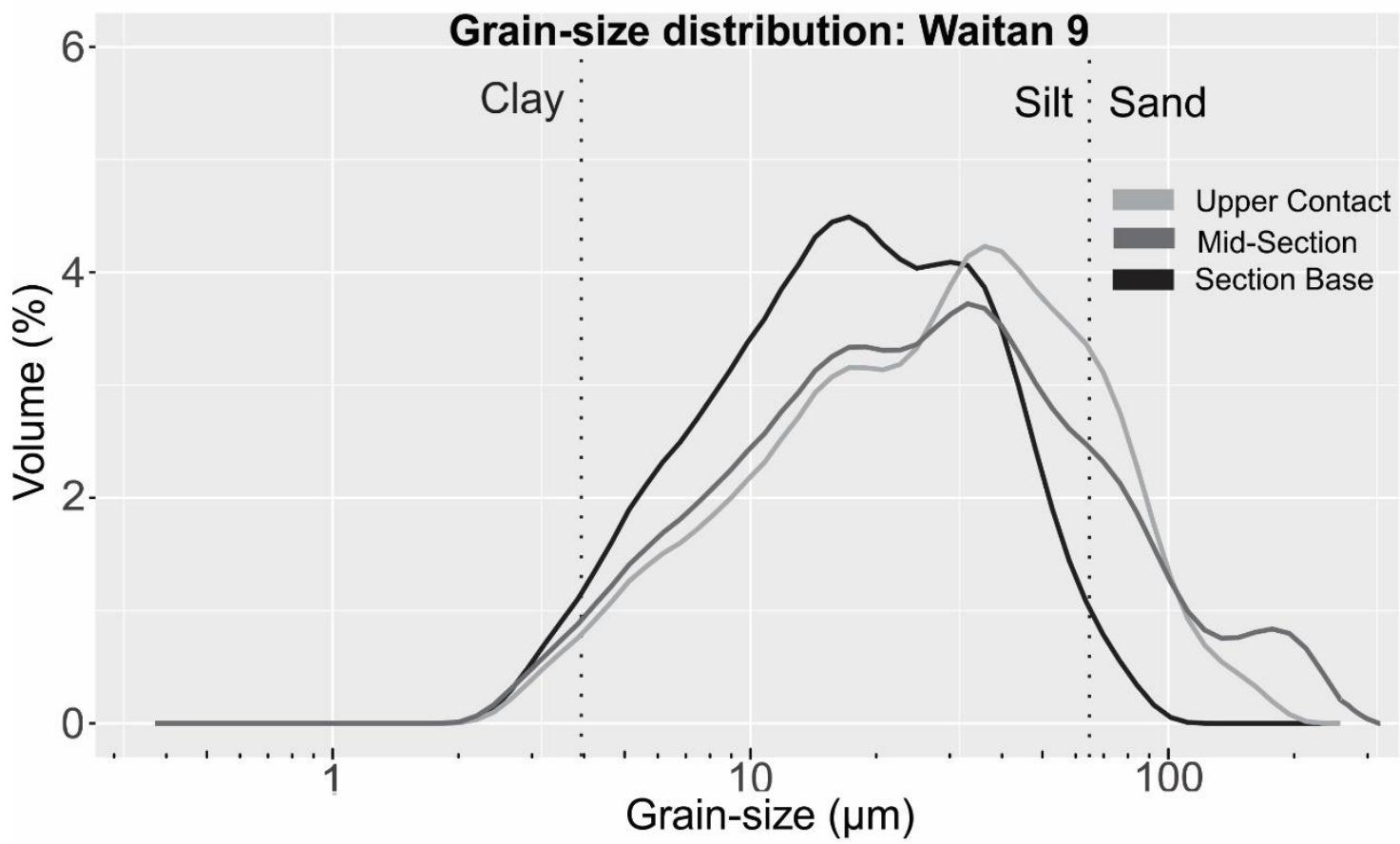

Figure 3.11 Grain-size profile for bulk samples from field site Waitan-9. Samples taken at base, middle and upper part of visible outcrop section. Full datasets available in Digital Appendix C.

\section{Clast shape analysis}

Detailed clast analysis could not be carried out on clasts in the laminated siltstone unit at field site Waitan-9, as only four clasts were found. All clasts collected were angular to very angular in shape, with $\mathrm{C}$ : A axis ratios of $<0.4$. One clast was noted to preserve minor crosscutting striations, comparable to clasts in the laminated siltstone unit at the Waitan-6 field site. Clast lithologies consist weakly foliated sandstone to semi-schist, with no well-foliated high-grade schist observed. These observations are directly comparable to clasts sampled from the laminated siltstone unit exposed at the lower Waitangitaona section outcrops. 


\subsubsection{Key facies}

The three facies identified from the lower Waitangitaona sections are recognised in the laminated siltstone unit at field site Waitan-9, with facies descriptions remaining the same (Figure 3.12). The facies associations observed for facies Fl, Flr and Fmd differ slightly from those developed at the lower Waitangitaona section however.

At the Waitan-9 site, facies Flr is observed to be more common, with facies Fl becoming minor. Further, the architecture of Fl and Fmd facies are observed to be more complex, appearing as very finely laminated, $\mathrm{mm}$ scale discrete beds. The interpretation of depositional processes involved in producing the individual facies are considered comparable between sites, presented in Section 3.1.5.
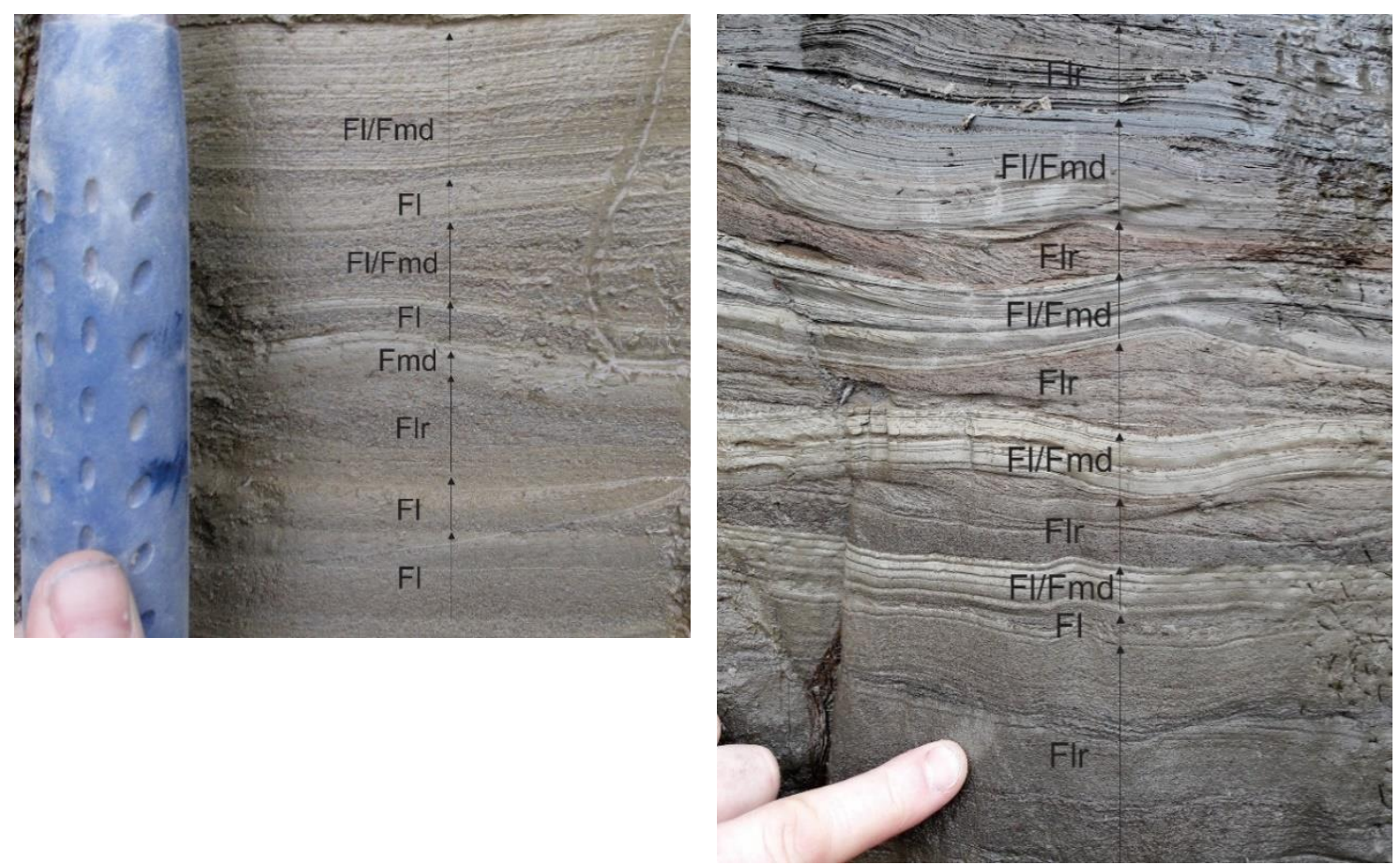

Figure 3.12 Facies identified from laminated siltstone unit exposed at field site Waitan-9, noted to be directly comparable to facies identified from the laminated siltstone unit exposed at the lower Waitangitaona section outcrops.

\subsubsection{Facies interpretation and depositional model}

The following interpretations are developed for facies identified in laminated siltstone units exposed at the lower Waitangitaona section, and Waitan-9 field site.

Interpretations are based upon those of Bennett et al. (2002), Carrivick and Tweed (2013) and Mager and Fitzsimons (2007), in the analysis of deposits with comparable facies architecture. 
Facies Fl, and Flr closely resemble rhythmite deposits, interpreted as density flow deposits associated with pro-glacial lake sedimentation (Bennett et al., 2002). The presence of striated, angular lonestone clasts in the laminated siltstone units supports the interpretation of deposition in a pro-glacial lake setting, implying transport via ice rafting mechanisms (Carrivick and Tweed, 2013). Additionally, when plotted on an RA$\mathrm{C}_{40}$ diagram, clasts sampled from the laminated siltstone unit at Waitan-6 plot centrally in the transport field associated with supra-glacial transport (Appendix B2).

Interpretations for individual facies identified from the laminated siltstone units exposed at both sections is presented below (Table 6). These facies and facies interpretations are utilised to develop the facies scheme and depositional model for glacio-lacustrine sedimentation presented in Chapter 4.

Table 6 Interpretation of facies identified in the laminated siltstone units at the lower Waitangitaona sections, and Waitan-9 field site.

\begin{tabular}{|c|c|c|c|}
\hline Particle Grade & Facies code & Lithofacies & Interpretation \\
\hline \multicolumn{4}{|l|}{ Fine sand-clay } \\
\hline & $\mathrm{Fl}$ & $\begin{array}{l}\text { Dark-light grey, } \\
\text { coarse to fine laminated } \\
\text { silts with rare clasts }\end{array}$ & $\begin{array}{l}\text { Glacio-lacustrine deposit, formed by density flows exiting } \\
\text { delta/subaqeous meltwater conduits, lonestones deposited by ice rafting }\end{array}$ \\
\hline & Flr & $\begin{array}{l}\text { Dark-light grey, } \\
\text { coarse silts with } \\
\text { x lamination }\end{array}$ & $\begin{array}{l}\text { Glacio-lacustrine deposit, formed by density flows of greater magnitude than } \\
\text { Fl events forming migrating ripple bedforms }\end{array}$ \\
\hline & Fmd & $\begin{array}{l}\text { Light grey, fine silt to } \\
\text { clay }\end{array}$ & $\begin{array}{l}\text { Glacio-lacustrine deposit formed from by suspension settling, } \\
\text { draping underlying bedforms }\end{array}$ \\
\hline
\end{tabular}

Through these facies interpretations, the depositional environment for the laminated siltstone units at the lower Waitangitaona sections and Waitan-9 field site is interpreted as an ice contact glacio-lacustrine setting. A lack of calcareous macro/micro-fauna in sediment samples supports this interpretation, showing the depositional environment to be lacustrine opposed to marine.

To expand upon this interpretation a two-dimensional depositional model is developed, detailing the depositional environment for the laminated siltstone units at the lower Waitangitaona sections and Waitan-9 field site (Figure 3.13). 


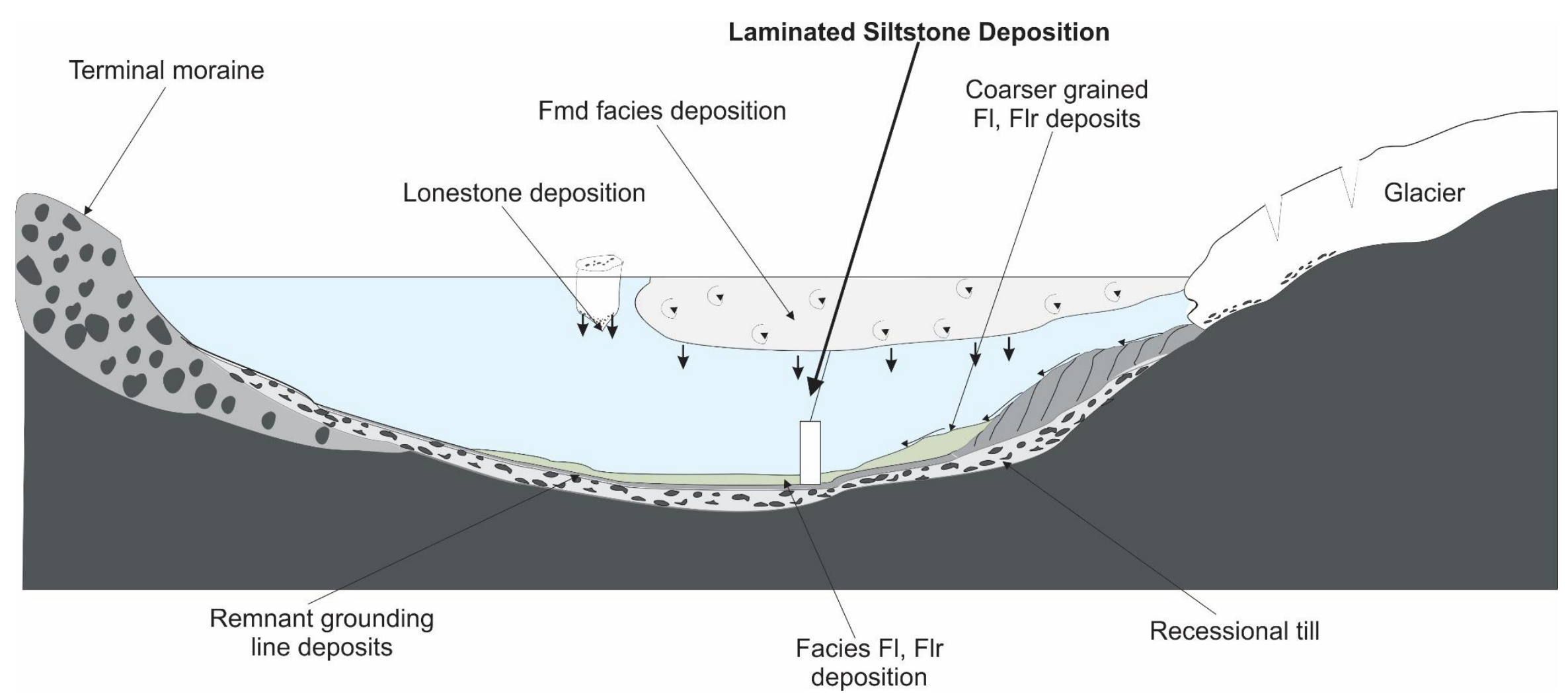

Figure 3.13 Schematic depositional model for the laminated siltstone units at the lower Waitangitaona sections and Waitan-9 field site. 


\subsection{Arahura River Sections}

The Arahura River is situated $~ 25$ kilometres inland from the Hokitika Township, with a drainage area extending eastwards to the Main Divide. Upon exiting the range front, the Arahura River drains north-westwards, bordered by localised knobs of Western Province granitoid and meta-sedimentary rock (Nathan et al., 2002).

The geology of the Arahura catchment is dominated by schists, semi-schists and sandstones of the Eastern Province (Nathan et al., 2002). A series of meta-igneous lenses of the Pounamu Ultramafic group also outcrop eastwards of the Alpine Fault. West of the Alpine Fault, the Arahura River is bordered by late Pleistocene moraine and outwash material as well as Western Province basement (Figure 3.14) (Barrell, 2011, Nathan et al., 2002).

Field investigation in the Arahura valley defined two key field sites between the uppermost road bridge and the "Cesspool" swing bridge. Lithological units identified at the sites are previously unmapped, with outcrop exposures being laterally continuous on a 10-300 metre scale. Field sites are termed the Arahura Bridge and Cesspool sections.

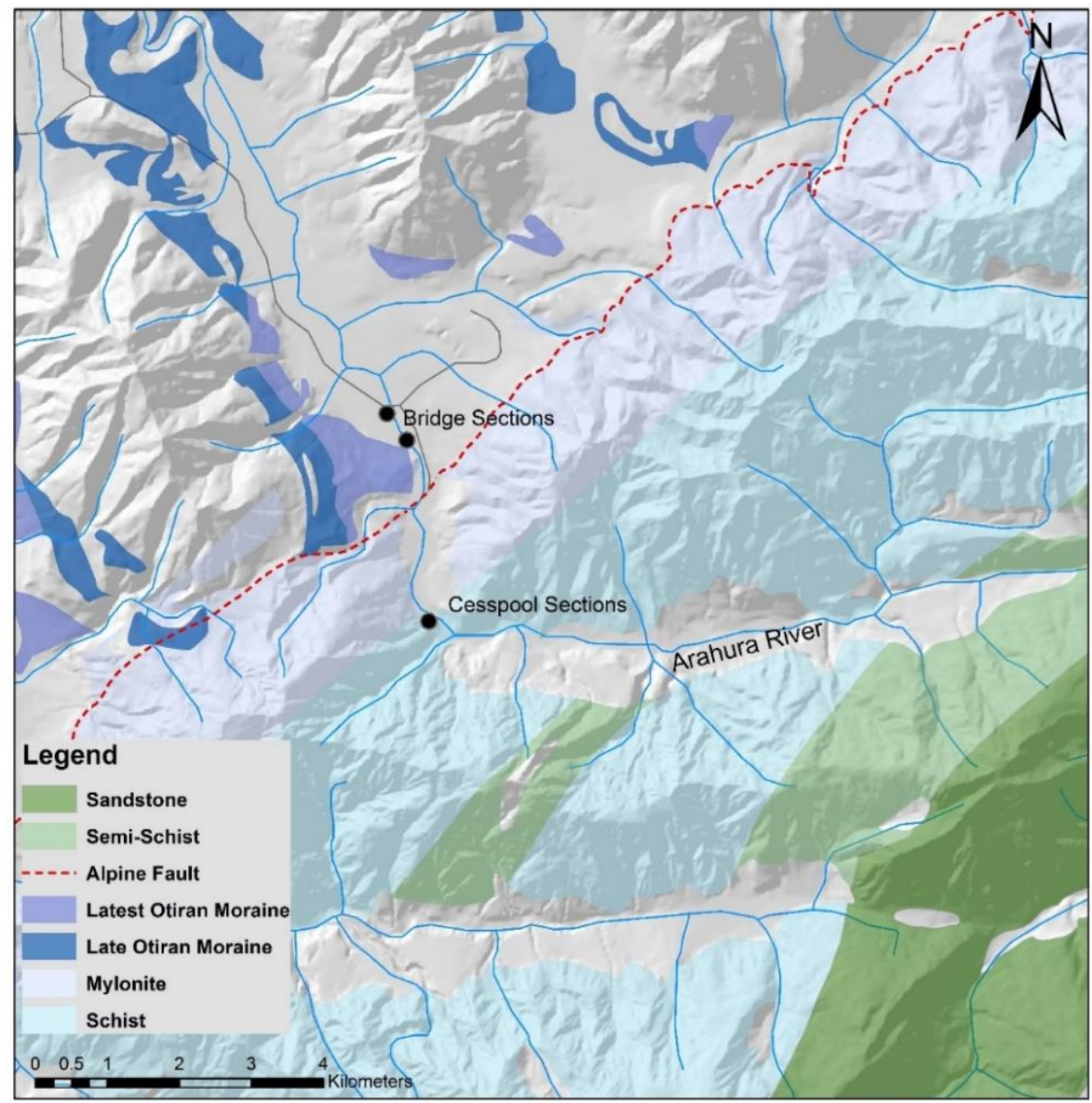

Figure 3.14 Geology of the area surrounding the Arahura River, with key field sites identified. Unshaded grey areas consist Quaternary fluvial or glacial units, ultramafic schist or Western Province bedrock. Mapped bedrock lithology and Alpine Fault trace mapped by Nathan et al. (2002), Moraines mapped by Barrell et al. (2013). 


\subsubsection{Arahura Bridge section}

A key lithological unit was identified in a 500-metre outcrop sequence parallel to the Arahura River (Table 7). The gross lithology of the unit identified is a moderately steeply dipping, interbedded matrix and clast supported conglomerate. Herein referred to as the conglomerate unit, this unit was sampled and documented using image based modelling (IBM) techniques. The overlying 10-metre thick horizontally bedded conglomerate unit was also documented using IBM techniques though was not analysed further in this study.

Table 7 Outcrop exposure of the conglomerate unit at the Arahura Bridge section, with measured thickness, lateral continuity and base elevation. Note: coordinates mark two end positions of outcrop.

\begin{tabular}{|lllcl|}
\hline Site Name & Position (NZTM) & $\begin{array}{l}\text { Estimated minimum outcrop Observed lateral continuity } \\
\text { thickness }(\mathrm{m})\end{array}$ & $\begin{array}{l}\text { Elevation (base of visible } \\
\text { section, M.A.S.L) }\end{array}$ \\
\hline \multirow{5}{*}{ Bridge Section } & & & & \\
& E1455829 & & & \\
& N5256399 & & & \\
& E1455583 & & & \\
& N5256717 & $6-10$ & & \\
\hline
\end{tabular}

\section{Stratigraphic position}

The conglomerate unit at the Arahura Bridge section is located within latest Otiran moraine limits for the Arahura valley (Barrell et al., 2013). The unit therefore lies in a position where ice would have been present during the LGM.

The conglomerate unit is unconformably overlain by a flat lying conglomerate unit, though no relevant age determinations can be made from this observation. No other sedimentary sequences with chronology available can be used to evaluate stratigraphic position.

\section{Image log}

The use of image based modelling and ortho-photographic techniques allowed clast size and orientation, as well as bed thickness and lateral continuity to be quantitatively analysed. A section constructed from outcrop ortho-photos of the conglomerate unit is displayed in Figure 3.15, associated with the measured section displayed in Figure 3.16. 


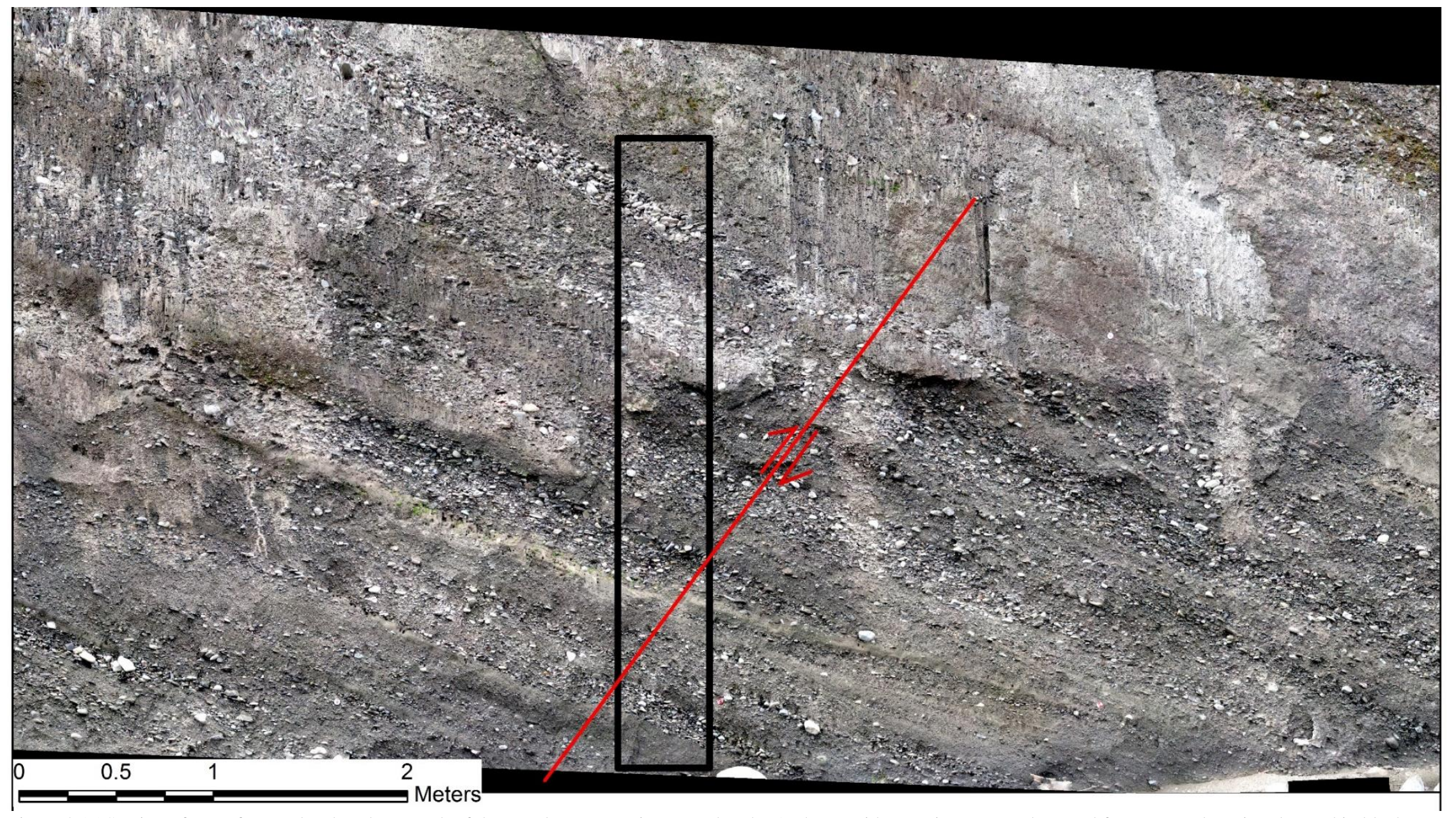

Figure 3.15 Section of georeferenced ortho-photograph of the conglomerate unit exposed at the Arahura Bridge section. Image log used for measured section denoted in black. Normal fault annotated in red, $\sim 8 \mathrm{~cm}$ offset measured. 


\section{Measured Log}

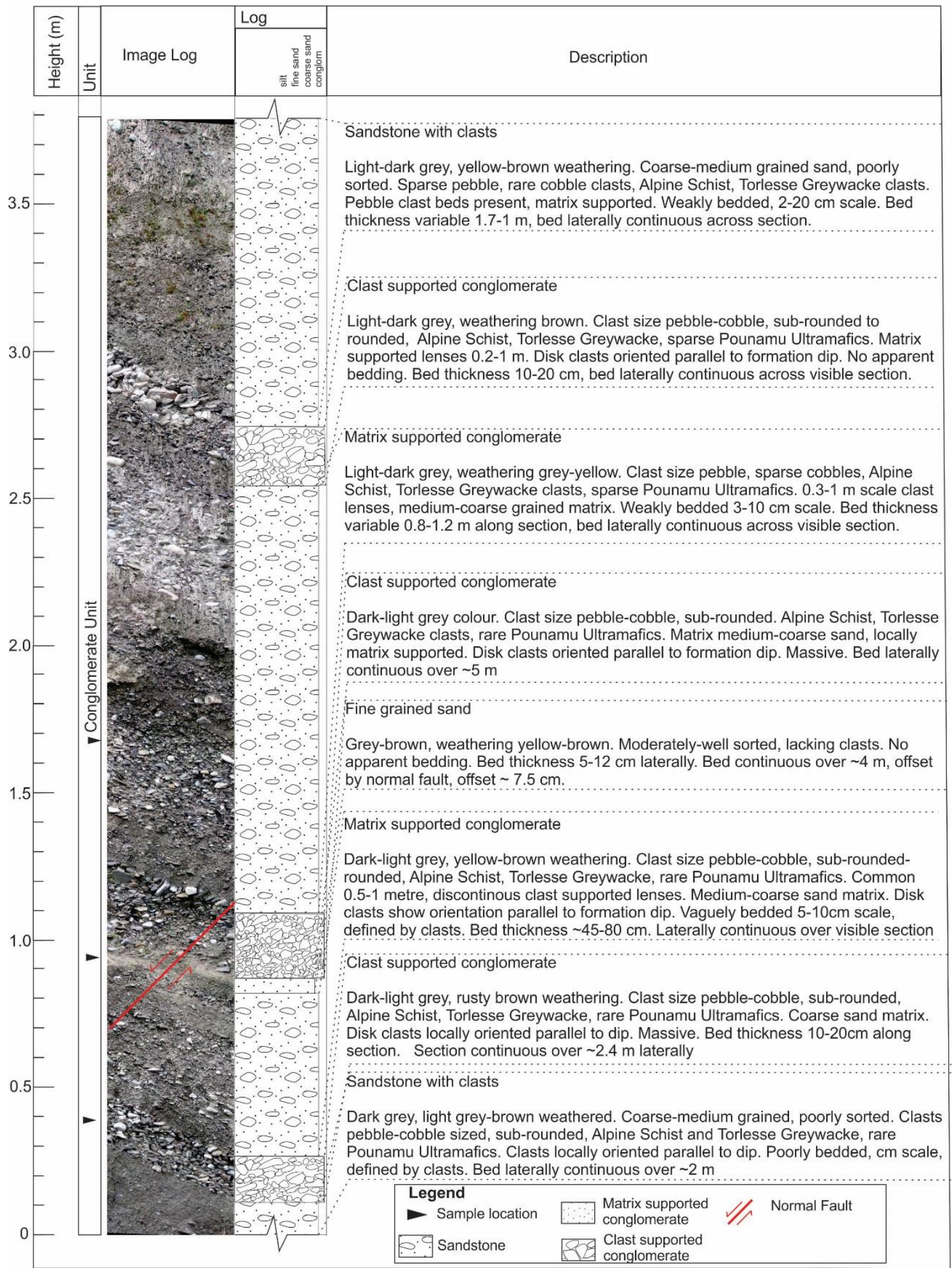

Figure 3.16 Measured section with image log through the conglomerate unit at the Arahura Bridge section.

\section{Results}

This section presents results from the analysis of the conglomerate unit displayed in

Figure 3.15 and logged in Figure 3.16. 


\section{Clast Shape}

Bulk samples were collected at two locations in the conglomerate unit, to be analysed using clast shape methods. Samples were taken at approximately 100 metre intervals along the visible outcrop, and represent the integration of multiple matrix and clast supported beds.

Clasts in the conglomerate unit display a broad scatter in clast form, though the majority of clasts display an intermediate block-slab-elongate morphology (Figure 3.17, left figures). Mean C/A ratio for samples is 0.36 (Sample 1) and 0.38 (Sample 2). Krumbein roundness analysis displays a broad normal distribution of clast roundness, with a modal roundness of 0.6 (Sample 1) and 0.5 (Sample 2), both classified as sub-rounded.
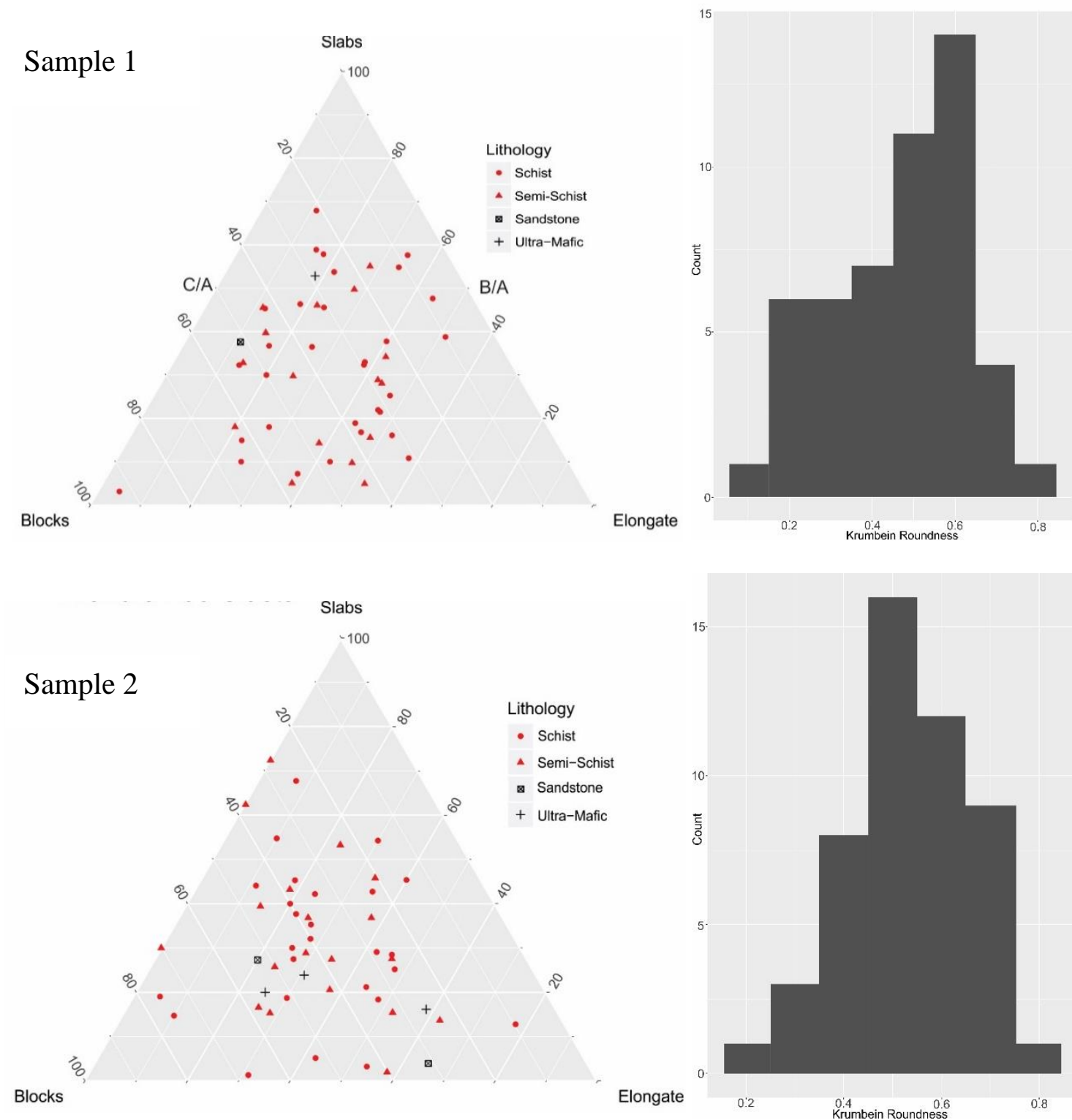

Figure 3.17 Clast form ternary and Krumbein roundness histogram for two samples in the conglomerate unit at the Arahura Bridge section. Summary data available in Appendix A3. 


\section{Clast lithology}

Clast lithology was examined alongside clast shape measurements. Clasts present in the conglomerate unit consist material derived from the hanging wall of the Alpine Fault, including a suite of samples from greywacke sandstone to amphibolite schist, with rare Pounamu Ultramafics. No Western Province granitoid or meta-sedimentary rocks are observed in this unit.

\subsubsection{Key facies}

Three key facies are identified in the conglomerate unit exposed at the Arahura Bridge section (Table 8, Figure 3.18). These key facies are utilised in developing a facies scheme and depositional model.

Table 8 Key facies recognised in the conglomerate unit exposed at the Arahura Bridge section.

\begin{tabular}{|c|c|c|c|c|}
\hline Particle Grade & Facies code & Lithofacies & Bedding/Sedimentary Structures & Facies association \\
\hline \multicolumn{5}{|c|}{ Coarse sand-Gravel } \\
\hline & Gct & $\begin{array}{l}\text { Grey-yellow, pebble to } \\
\text { cobble clasts }\end{array}$ & $\begin{array}{l}30-40 \mathrm{~cm} \text { thick massive discontinous } \\
\text { clast supported lenses, dipping } 20-25^{\circ}\end{array}$ & Alternating with Gmt, Sct \\
\hline & Gmt & $\begin{array}{l}\text { Grey-yellow, pebble- } \\
\text { cobble clasts, sand } \\
\text { matrix }\end{array}$ & $\begin{array}{l}40-60 \mathrm{~cm} \text { thick weakly bedded matrix } \\
\text { supported lenses, continous } 2-10 \text { metres } \\
\text { laterally, dipping } 20-25^{\circ}\end{array}$ & Alternating with Gct, Sct \\
\hline & Sct & $\begin{array}{l}\text { Light grey-brown, fine } \\
\text { to medium sand with } \\
\text { clasts }\end{array}$ & $\begin{array}{l}5-50 \mathrm{~cm} \text { thick, weakly bedded, pebble to } \\
\text { cobble clasts, continous } 5-15 \text { metres, } \\
\text { dipping } 20-25^{\circ}\end{array}$ & Alternating with Gct, Gmt \\
\hline
\end{tabular}

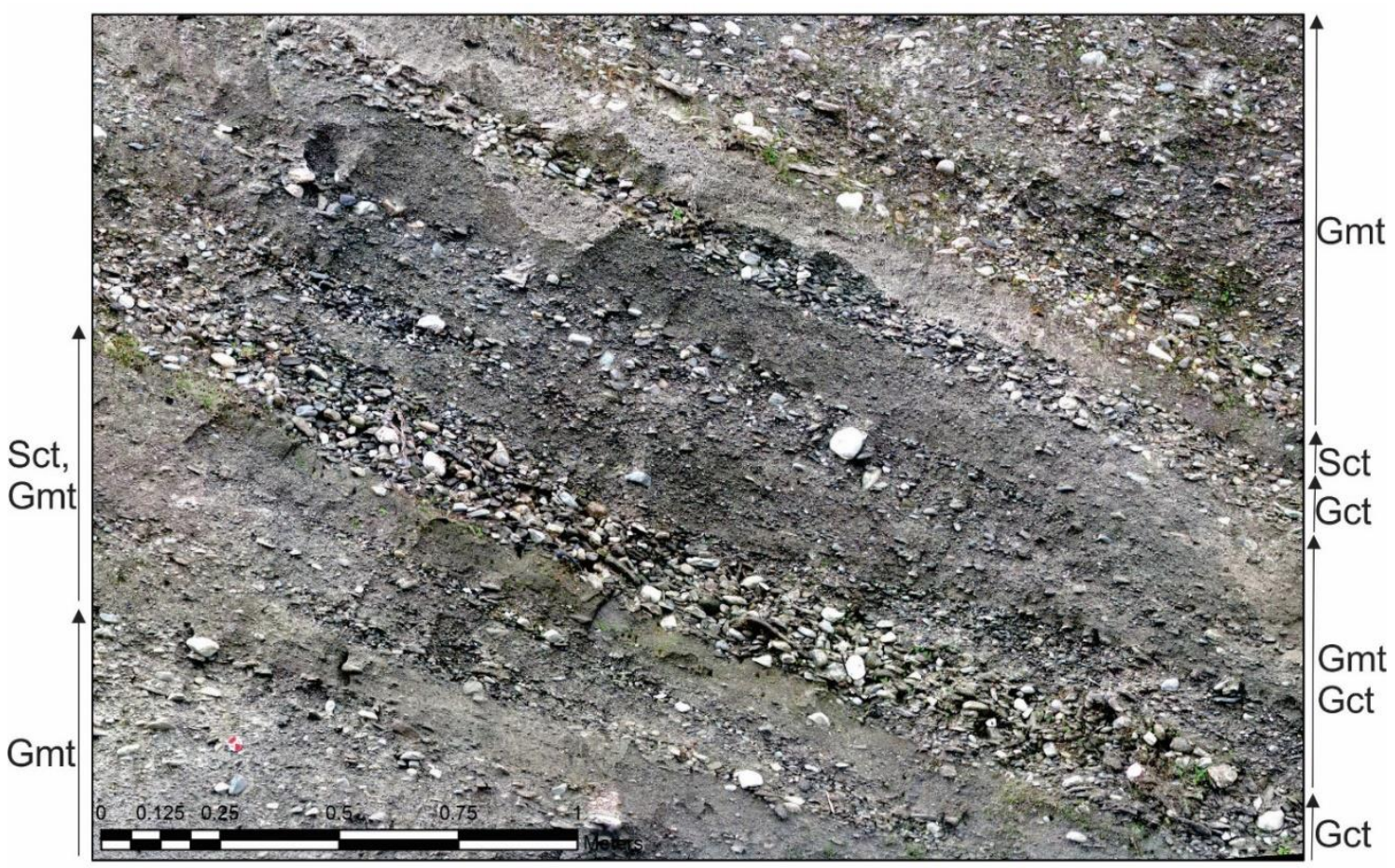

Figure 3.18 Annotated figure of facies identified from the conglomerate unit exposed at the Arahura Bridge section. 


\subsubsection{Arahura Cesspool Section}

A continuous sedimentary sequence is identified in a series of newly exposed outcrops (due to recent slope failure), grouped as the Cesspool section. Two key lithological units are visible at the Cesspool section, a basal sandy siltstone unit with sparse clasts (Table 9, Figure 3.19), and an overlying conglomerate unit directly comparable to that exposed and logged at the Arahura Bridge Section.

The underlying sandy siltstone unit consists a laminated siltstone interval, overlain by a conglomerate bed and a sandstone with clasts, shown in the measured section for this site (Figure 3.20). The overlying conglomerate unit is not described in Figure 3.20, as the section description for the conglomerate unit at the Arahura Bridge Section remains accurate, though the thickness of the conglomerate unit is greater at the Cesspool section ( 20-30 metres). The conglomerate unit is overlain by a boulder conglomerate, which could be seen but not accessed at the Cesspool section (Figure 3.19).

Table 9 Location of outcrop exposures at Cesspool section with estimated thickness, lateral continuity and base elevation.

\begin{tabular}{|ccccc|}
\hline Site Name & Position (NZTM) & \multicolumn{2}{c|}{$\begin{array}{l}\text { Estimated minimum outcrop Observed lateral continuity } \\
\text { thickness }(\mathrm{m})\end{array}$} & $\begin{array}{c}\text { Elevation (base of visible } \\
\text { section, M.A.S.L) }\end{array}$ \\
\hline $\begin{array}{c}\text { Sandy Siltstone } \\
\text { Unit }\end{array}$ & E1456186 & & & \\
$\begin{array}{c}\text { N5253885 } \\
\text { Sandy Siltstone- }\end{array}$ & E1456186 & 10.4 & $\sim 20$ & 191.4 \\
Conglom Contact & N5253872 & $20-30$ & $\sim 250$ & 202.4 \\
\hline
\end{tabular}

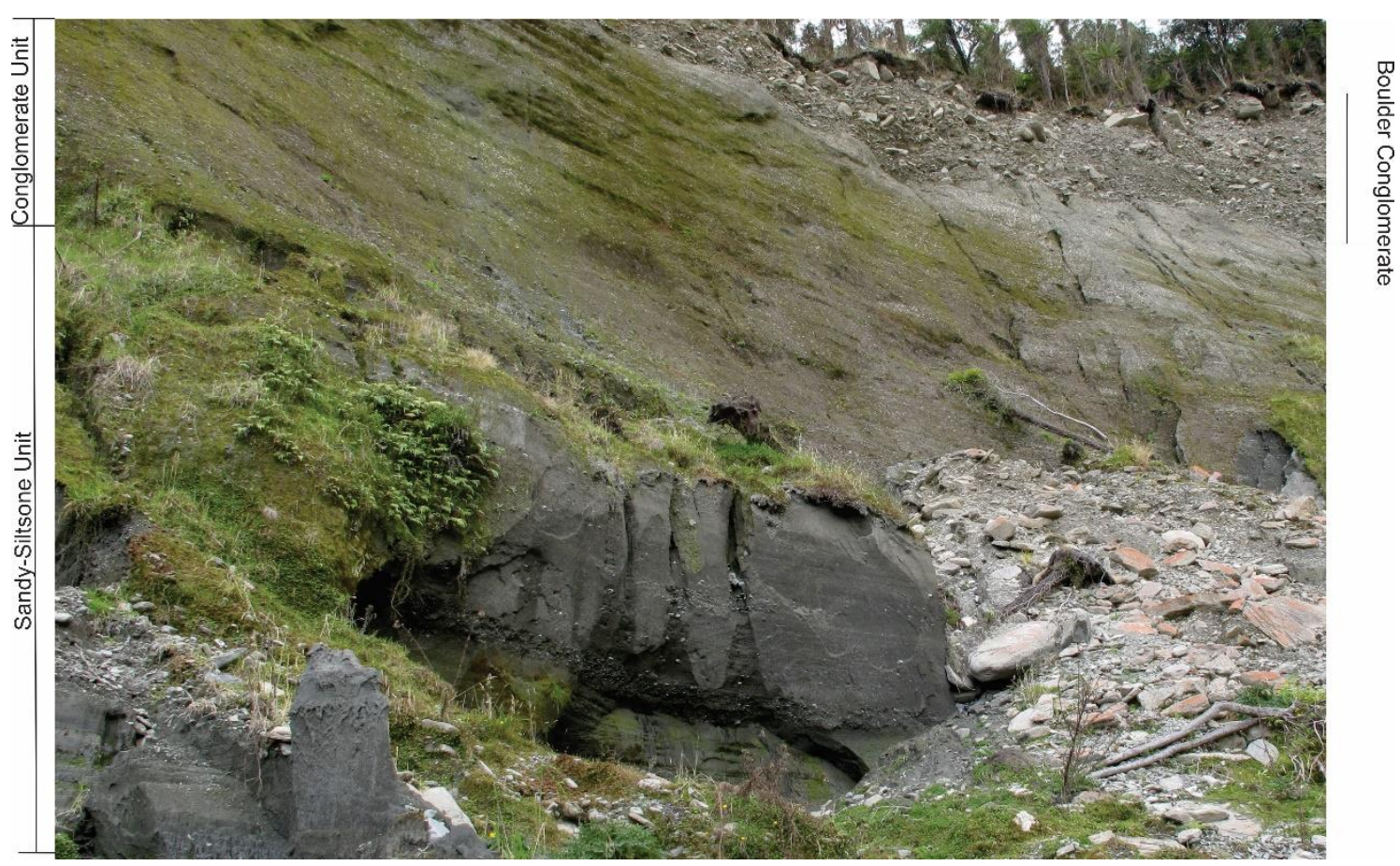

Figure 3.19 Exposure of sandy siltstone unit at the Cesspool section, overlain by the conglomerate unit also exposed at the Arahura Bridge Section. Conglomerate unit overlain by inaccessible boulder conglomerate. 


\section{Stratigraphic position}

Exposures at the Cesspool section do not overlie, underlie and are not proximal to any sedimentary sequences where chronology is available. High-grade schist bedrock is observed to outcrop in a gorge directly below the Cesspool section, though no contact between bedrock and the sandy siltstone unit was observed. The conglomerate unit is unconformably overlain by a horizontally bedded boulder conglomerate, though no chronology is available for this unit.

\section{Measured Section}

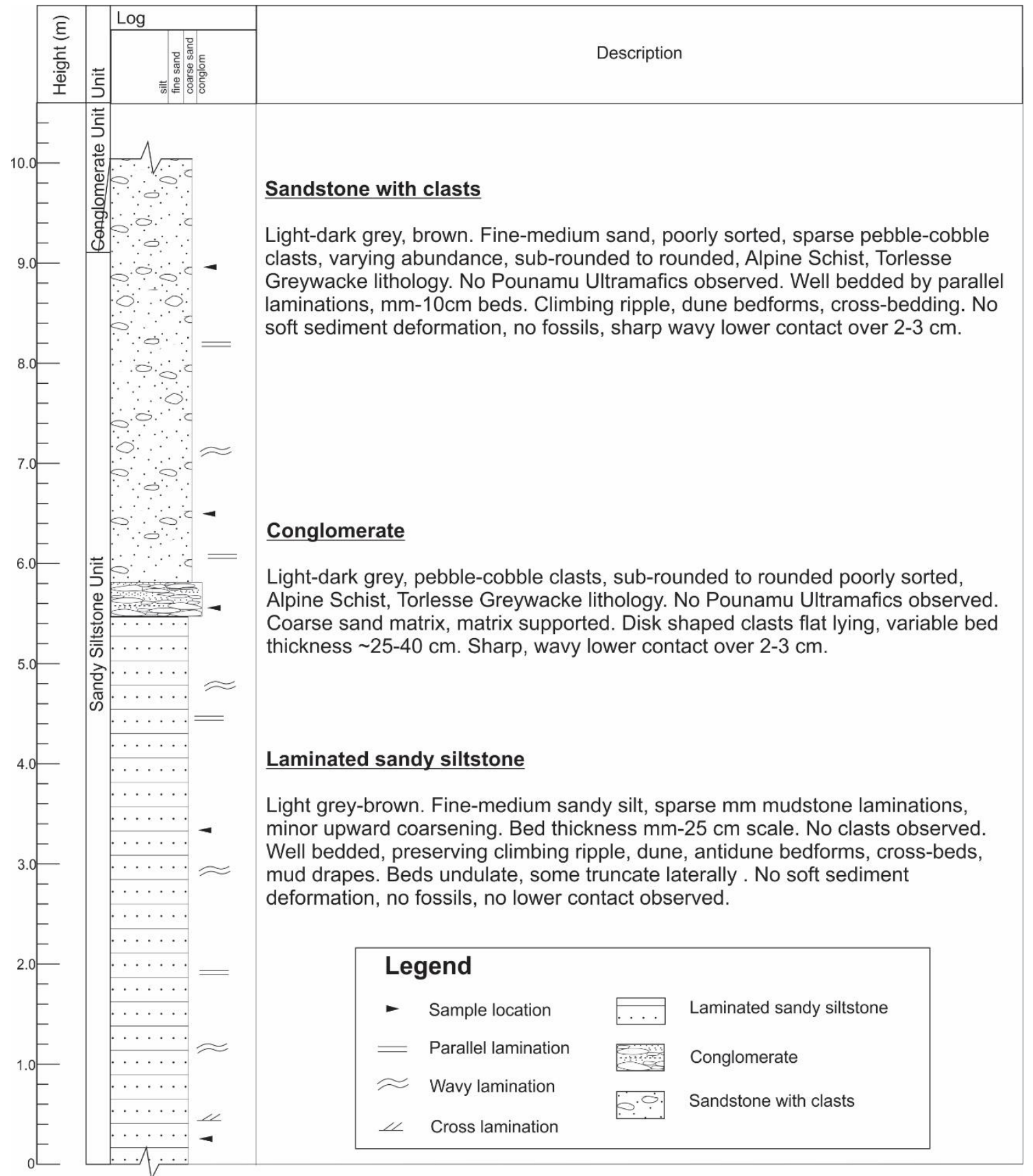

Figure 3.20 Measured section for the sandy siltstone unit exposed at the Cesspool section. Unit consists a laminated sandy siltstone, conglomerate and sandstone with clasts, being overlain by a conglomerate unit also comparable to the conglomerate unit at the Arahura Bridge section. 


\section{Results}

This section presents results from the analysis of the sandy siltstone unit exposed at the Cesspool section.

\section{Grain-size}

A single bulk grain-size from the sandy siltstone unit was used for grain-size analysis (Figure 3.21).

Grain-size shows a multimodal distribution, typical of bulk samples representing the integration of multiple discrete beds. Mean grain-size is calculated as $21.2 \mu \mathrm{m}$, with the grain-size profile displaying a significant volume percent of fine silt and clay particles, in addition to fine and medium sand.

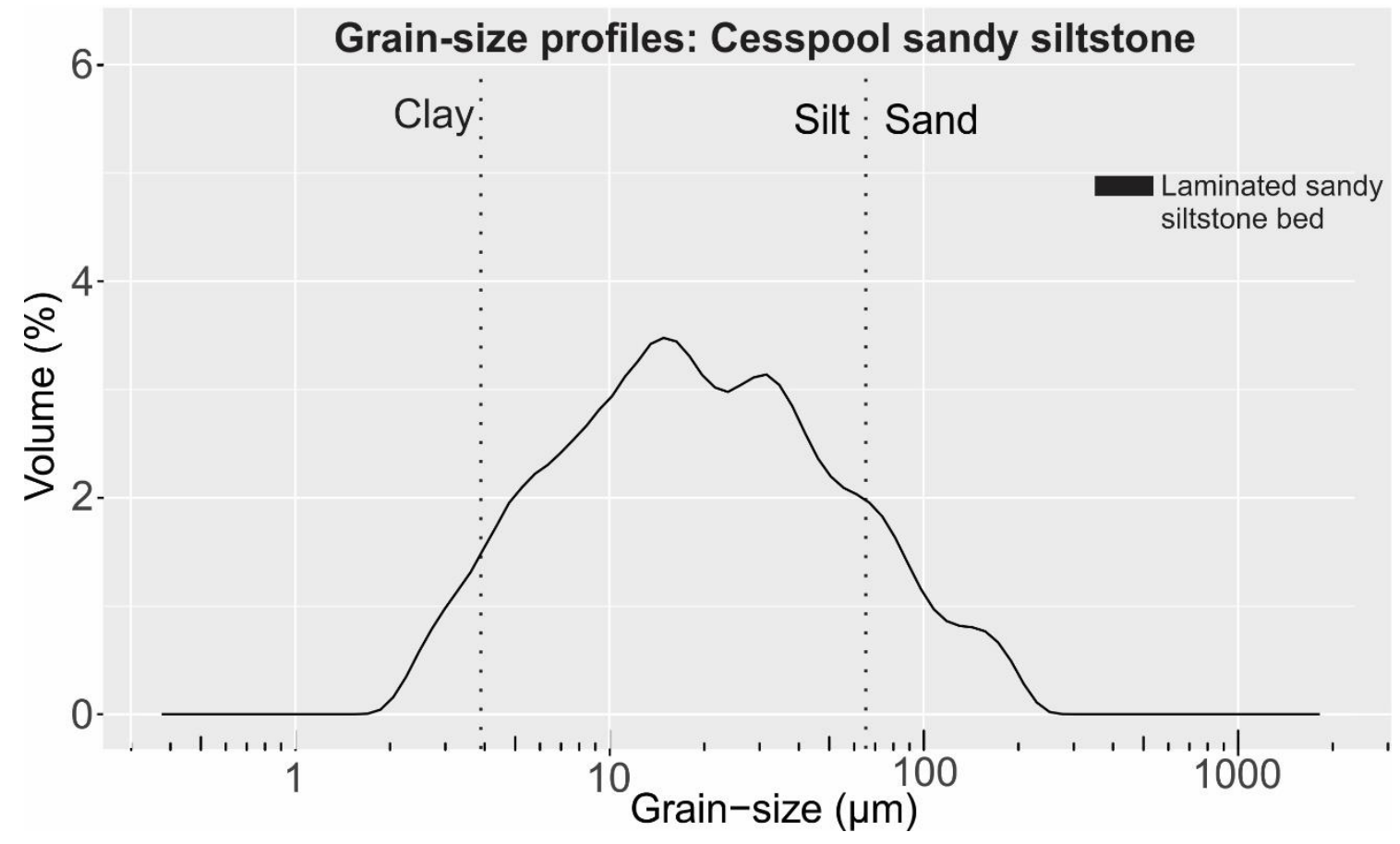

Figure 3.21 Grain-size profile from the sandy siltstone unit exposed at the Cesspool section.

\section{Clast shape analysis}

A bulk sample collected from a conglomerate bed in the sandy siltstone unit was analysed using clast shape methods (Figure 3.22).

Clast form analysis shows the majority of clasts displaying a blocky-elongate morphology. Mean C/A axis ratios for clasts is calculated as 0.36 . There is no clear relationship between clast lithology and form based on the ternary diagram. Krumbein 
roundness analysis shows a normal distribution of clast roundness, with a median roundness value of 0.5 (sub-rounded).
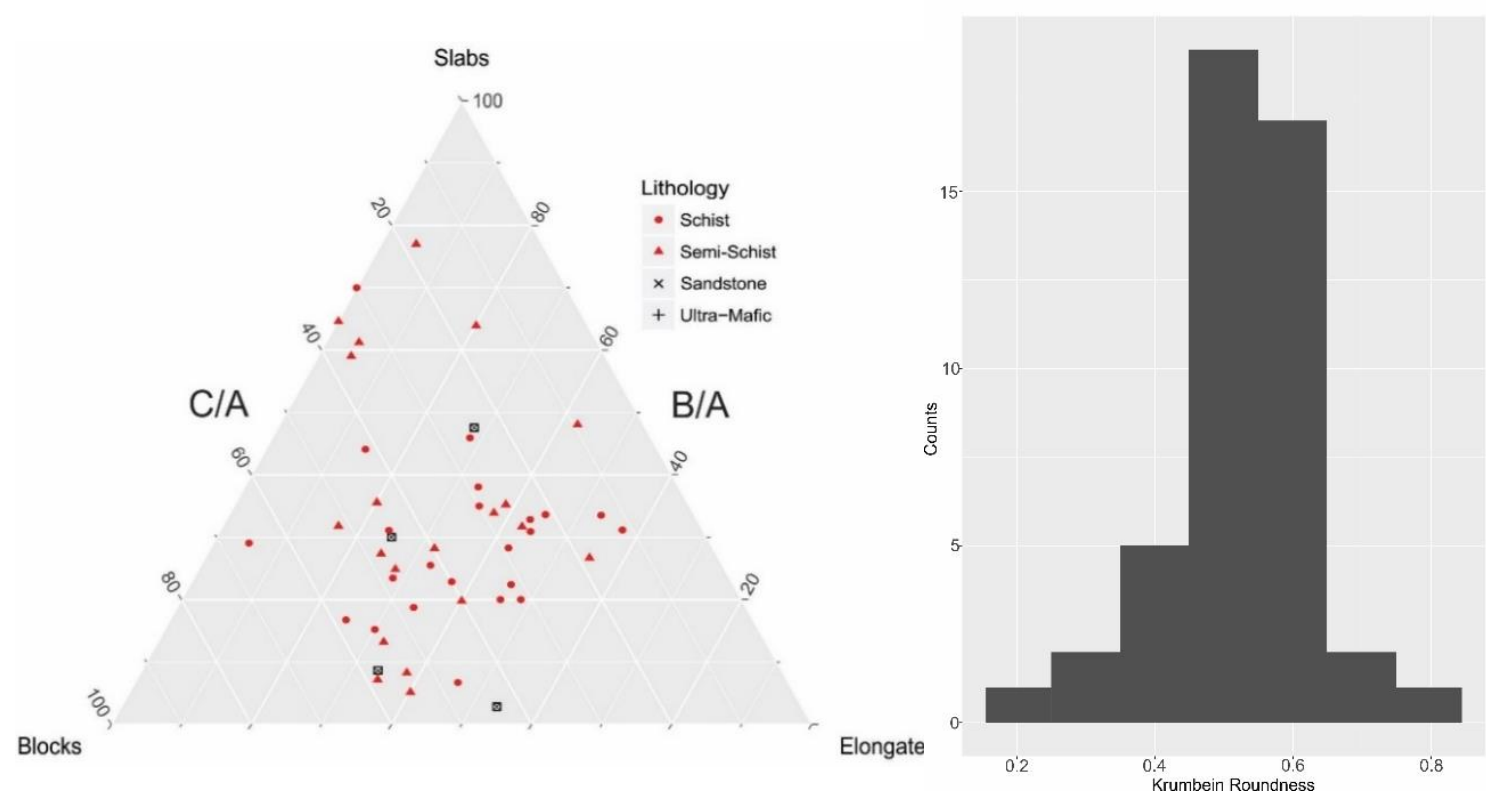

Figure 3.22 Clast form ternary and Krumbein Roundness histogram for clasts sampled from a conglomeratebed in the sandy siltstone unit exposed at the Cesspool section.

\subsubsection{Key facies}

Four key facies are identified from the sandy siltstone unit exposed at the Cesspool section (Table 10, Figure 3.23). These key facies are utilised in developing a facies scheme and depositional model.

Table 10 Facies identified from the sandy siltstone unit exposed at the Cesspool section.

\begin{tabular}{|c|c|c|c|c|}
\hline Particle Grade & Facies code & Lithofacies & Bedding/Sedimentary Structures & Facies association \\
\hline \multicolumn{5}{|c|}{ Fine-medium sand } \\
\hline & $\mathrm{Sl}$ & $\begin{array}{l}\text { Light grey-brown, fine } \\
\text { to medium sand }\end{array}$ & Horizontally laminated, beds $1-30 \mathrm{~cm}$ & Overlies facies $\mathrm{Sr}, \mathrm{Gmh}$ \\
\hline & $\mathrm{Sr}$ & $\begin{array}{l}\text { Light grey-brown, fine } \\
\text { to medium sand with } \\
\text { x-bedding }\end{array}$ & $\begin{array}{l}\text { Ripple, dune and anti-dune bedforms, } \\
\text { beds } 1-5 \mathrm{~cm}\end{array}$ & $\begin{array}{l}\text { Overlies facies } \mathrm{Sl} \text {, } \\
\text { overlain by facies Fmd }\end{array}$ \\
\hline & Slc & $\begin{array}{l}\text { Light grey-brown, fine } \\
\text { to medium sand with } \\
\text { clasts }\end{array}$ & $\begin{array}{l}\text { Horizontally laminated, beds } 1-30 \mathrm{~cm} \text {, } \\
\text { sparse pebble-cobble clasts }\end{array}$ & $\begin{array}{l}\text { Clasts only recognised in } \\
\text { Sl facies }\end{array}$ \\
\hline \multicolumn{5}{|l|}{ Gravel } \\
\hline & Gmh & $\begin{array}{l}\text { Pebble-cobble clasts, } \\
\text { sand matrix }\end{array}$ & $\begin{array}{l}\text { Matrix supported, crude horizontal } \\
\text { bedding, } 20-40 \mathrm{~cm} \text { bed thickness }\end{array}$ & Overlies $\mathrm{Sl}, \mathrm{Sr}$ facies \\
\hline
\end{tabular}



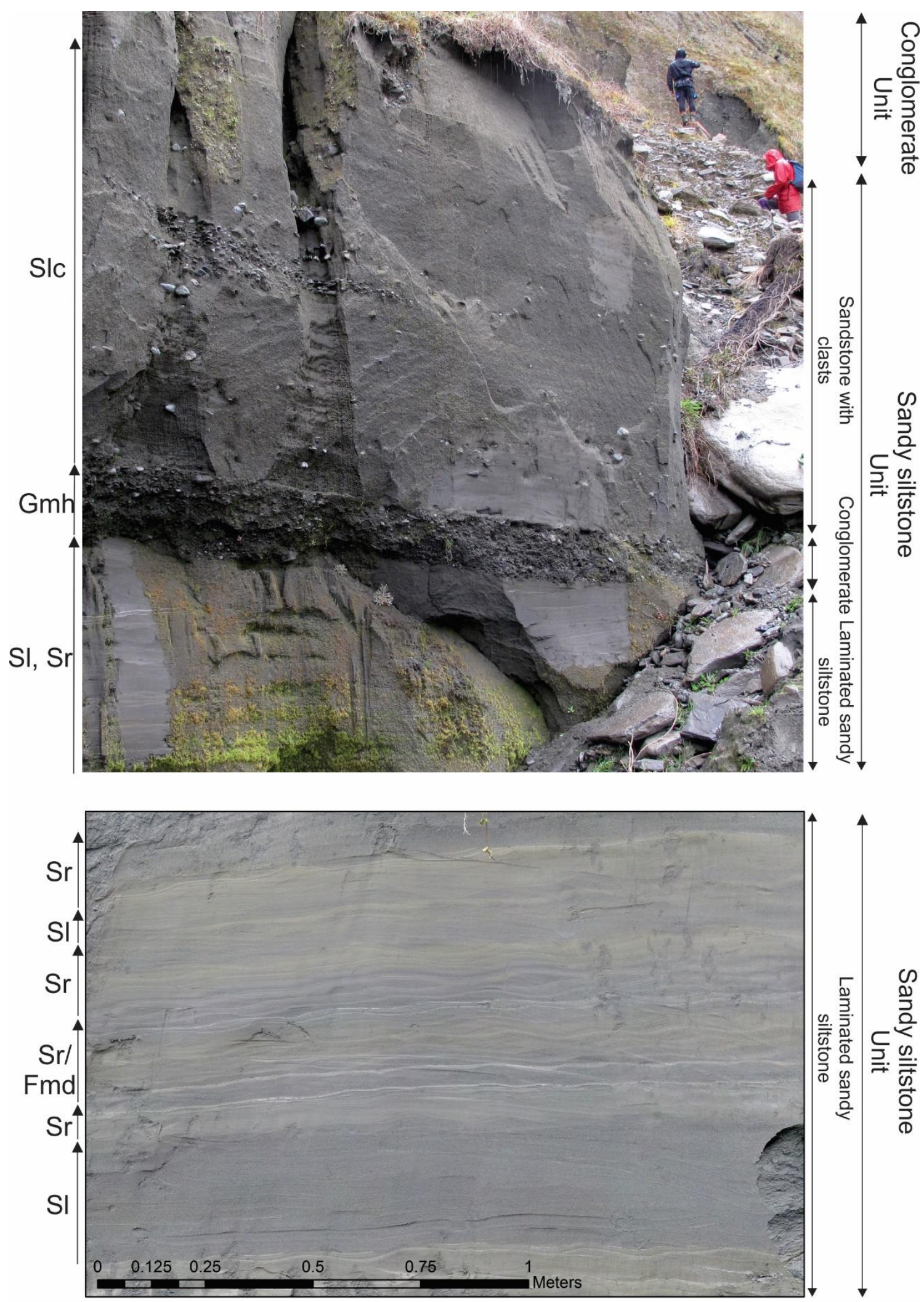

Figure 3.23 Top Image: Annotated field photo of sandy siltstone unit and overlying conglomerate unit at the Cesspool Section. Bottom Image: Ortho-photo of sandy siltstone unit at Cesspool section, displaying intervals identified in the stratigraphic column (Figure 3.20). Facies identified in unit intervals are annotated on left side of diagram. 


\subsubsection{Facies interpretation and depositional model}

This section presents interpretations for key facies identified from both the conglomerate unit exposed at the Arahura Bridge and Cesspool sections, and the sandy siltstone unit exposed at the Cesspool section. Interpretations are based upon those of comparable facies architecture identified by Bennett et al. (2002) and Carrivick and Tweed (2013).

\section{Sandy siltstone unit}

The presence of planar beds, ripple, dune, anti-dune structures, overlain by mud drapes in the sandy siltstone unit demonstrates deposition occurred in a variable flow regime setting, with high suspended sediment loads allowing the preservation of structures (Allen, 1971). Beds identified in this unit are horizontal, therefore were deposited on a horizontal or near horizontal bed-slope, contrasting to beds observed in the overlying conglomerate unit. No calcareous macro/micro fauna were found in sediments, suggesting deposition occurred in a lacustrine environment opposed to a marine environment.

The depositional environment for the sandy siltstone unit is interpreted as a low bed slope lacustrine setting, likely at or near the toe of an actively prograding delta. Density flows off the lacustrine delta are interpreted to produce the variable grain-size and flow regime deposits identified in outcrop. Clast shape analyses show clasts in this unit to be sub-rounded, preserving no remnant glacial form. Further, when presented as an RA-C40 diagram, clasts plot centrally in the glacio-fluvial transport field (Appendix B2). This is used to suggest clasts in the sandy siltstone unit underwent transport across a fluvial plain upstream of the lacustrine delta, prior to deposition at or near the delta toe.

$\bar{T}$ able 11 Interpretations for facies identified in the Cesspool Unit. Note: mass movement includes creep, $\overline{\text { slumps, }}$ debris flows and grain flows (Bennett et al., 2002).

\begin{tabular}{|c|c|c|c|}
\hline Particle Grade & Facies code & Lithofacies & Interpretation \\
\hline \multicolumn{4}{|c|}{ Fine-medium sand } \\
\hline & Sl & $\begin{array}{l}\text { Light grey-brown, fine } \\
\text { to medium sands }\end{array}$ & Sand dominated density flows deposited onto a low angle bed-slope \\
\hline & $\mathrm{Sr}$ & $\begin{array}{l}\text { Light grey-brown, fine } \\
\text { to medium sands with } \\
\text { x-bedding }\end{array}$ & $\begin{array}{l}\begin{array}{l}\text { Density flows/currents with variable flow regimes deposited on a low angle } \\
\text { bed-slope }\end{array}\end{array}$ \\
\hline & Slc & $\begin{array}{l}\text { Light grey-brown, fine } \\
\text { to medium sands with } \\
\text { clasts }\end{array}$ & Sand/clast dominated density flows deposited on a low angle bed-slope \\
\hline \multicolumn{4}{|l|}{ Gravel } \\
\hline & Gmh & $\begin{array}{l}\text { Pebble-cobble clasts, } \\
\text { sand matrix }\end{array}$ & Clast rich mass movement deposits, deposited on a low angle bed-slope \\
\hline
\end{tabular}




\section{Conglomerate unit}

The conglomerate unit exposed at the Arahura Bridge and Cesspool sections is underlain by the horizontally bedded sandy siltstone unit. This indicates the $\sim 25^{\circ}$ dip angle displayed by beds in the unit cannot have been attained due to tectonics. Clast and matrix supported lenses were instead deposited on a bed-slope with an angle between $20-25^{\circ}$. This finding restricts the depositional environment of the conglomerate unit to a specific setting.

The conglomerate unit is interpreted as deposited as part of an actively prograding lacustrine delta. The unit bears a close resemblance to rhythmically alternating and steeply dipping conglomerate lobe deposits analysed by Bennett et al. (2002), interpreted as actively prograding delta deposits. Comparable to the underlying sandy siltstone unit, clasts in the conglomerate unit preserve no remnant glacial form, and plot centrally in the glacio-fluvial transport field on an $\mathrm{RA}-\mathrm{C}_{40}$ diagram (Appendix B2). This is used to suggest clasts underwent transport and reworking across a fluvial plain prior to deposition on a lacustrine delta slope.

This interpretation is supported by evidence from the underlying sandy siltstone unit, interpreted as deposited in a delta toe setting. The vertical facies succession observed through the sandy siltstone and overlying conglomerate unit is therefore interpreted to represent the migration of laterally adjacent environments.

Interpretations of facies identified in the conglomerate unit are presented in Table 12:

Table 12 Interpretations for facies identified in the conglomerate unit exposed at the Arahura Bridge and Cesspool sections. Note: mass movement includes creep, slumps, debris flows and grain flows.

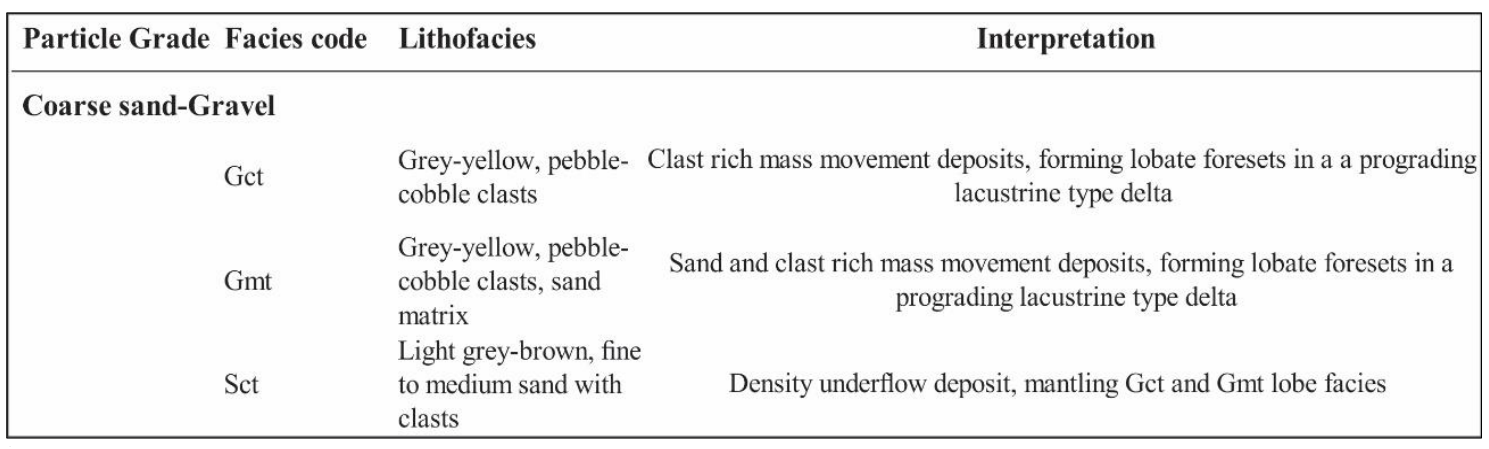

To expand upon the interpretations for the sandy siltstone and conglomerate units, a two-dimensional depositional model is developed, detailing the depositional setting for both units identified (Figure 3.24). 


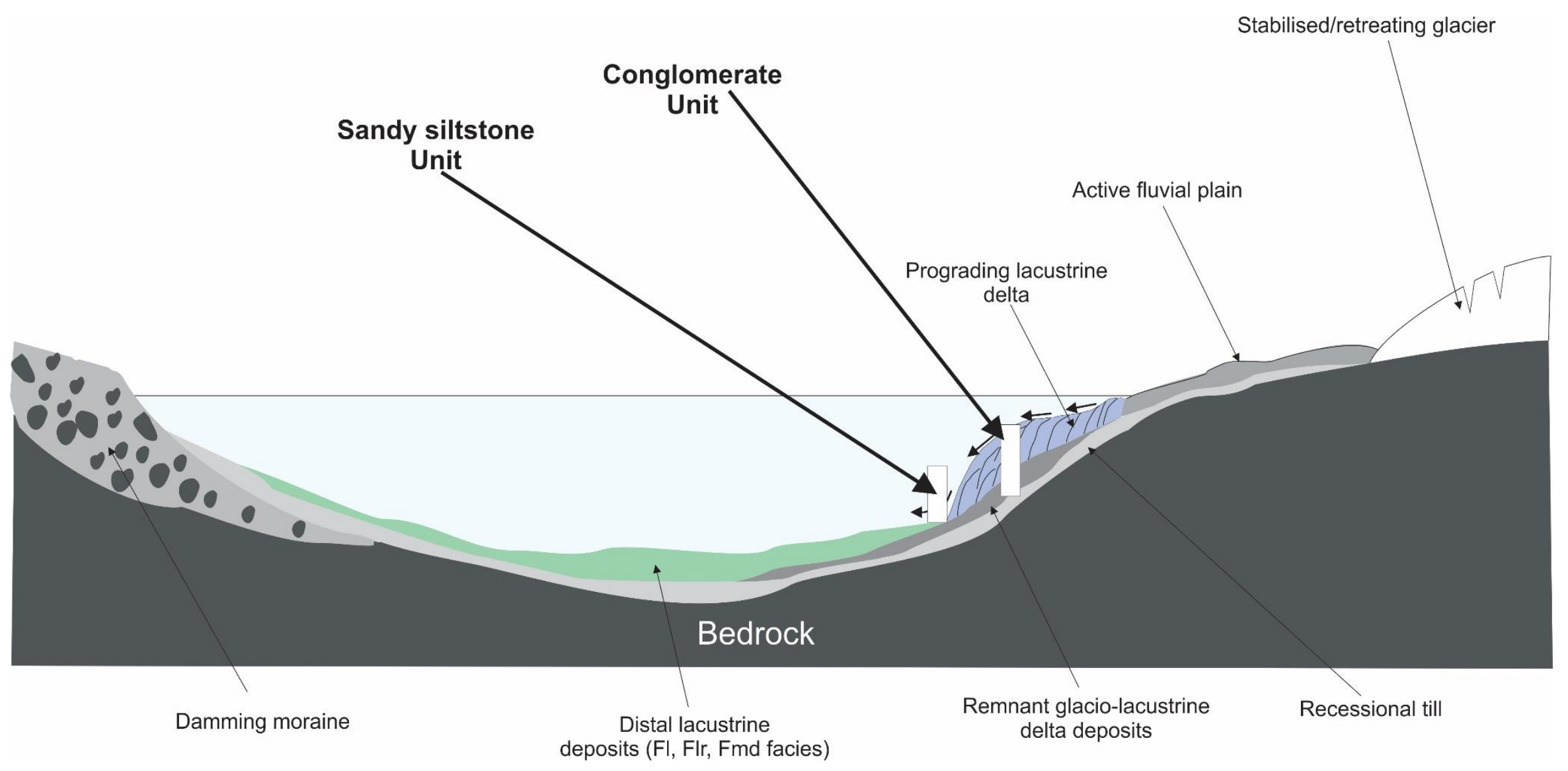

Figure 3.24 Schematic depositional model for the sandy siltstone unit exposed at the Cesspool section, and the conglomerate unit exposed at the Arahura Bridge and Cesspool sections. 


\subsection{Whataroa section}

Through re-investigation of terrace deposits mapped by Klahn (2011), a key lithological unit was identified for analysis. The gross lithology of the unit identified is a pebblecobble conglomerate, exposed in a 50-metre long outcrop in the Whataroa River. This unit is herein referred to as the pebble-cobble conglomerate unit, exposed in the Whataroa section (Figure 3.25).

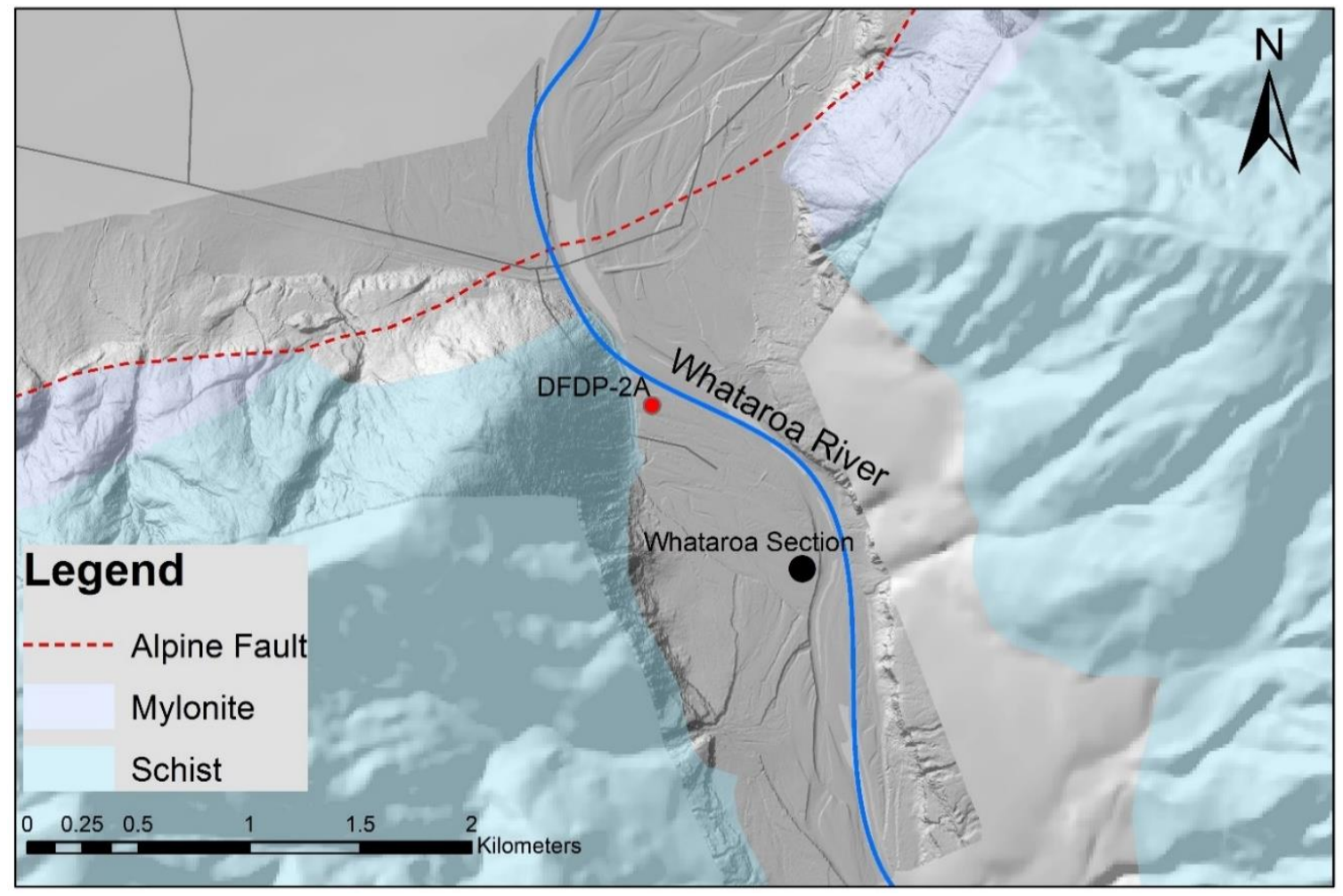

Figure 3.25 Bedrock geology and topography surrounding the Whataroa field site, with Whataroa LIDAR DEM overlain on 15m LINZ DEM. Bedrock lithology and Alpine Fault mapped by Cox and Barrell (2007). Unshaded region represents Quaternary alluvial and glacial units.

\section{Stratigraphic position}

The pebble-cobble conglomerate unit is overlain by 1300-1600 A.D cobble-boulder conglomerate analysed by Klahn (2011) Using stratigraphic correlation with units exposed upstream, the pebble-cobble conglomerate unit is inferred using to be 10-15 kyr in age (S. Cox, 2017, pers.comm).

\section{Measured section}

A 24-metre section of the 50-metre outcrop was logged in the field, and a section photo-log used to generate an outcrop IBM. To display along strike variability, an annotated section ortho-photograph is displayed opposed to a measured section (Figure 3.26). 
Overlying unit, cobble-boulder conglomerate, matrix supported, sub-rounded-rounded clasts. Sporadic logs and branches, sharp undulating lower contact.

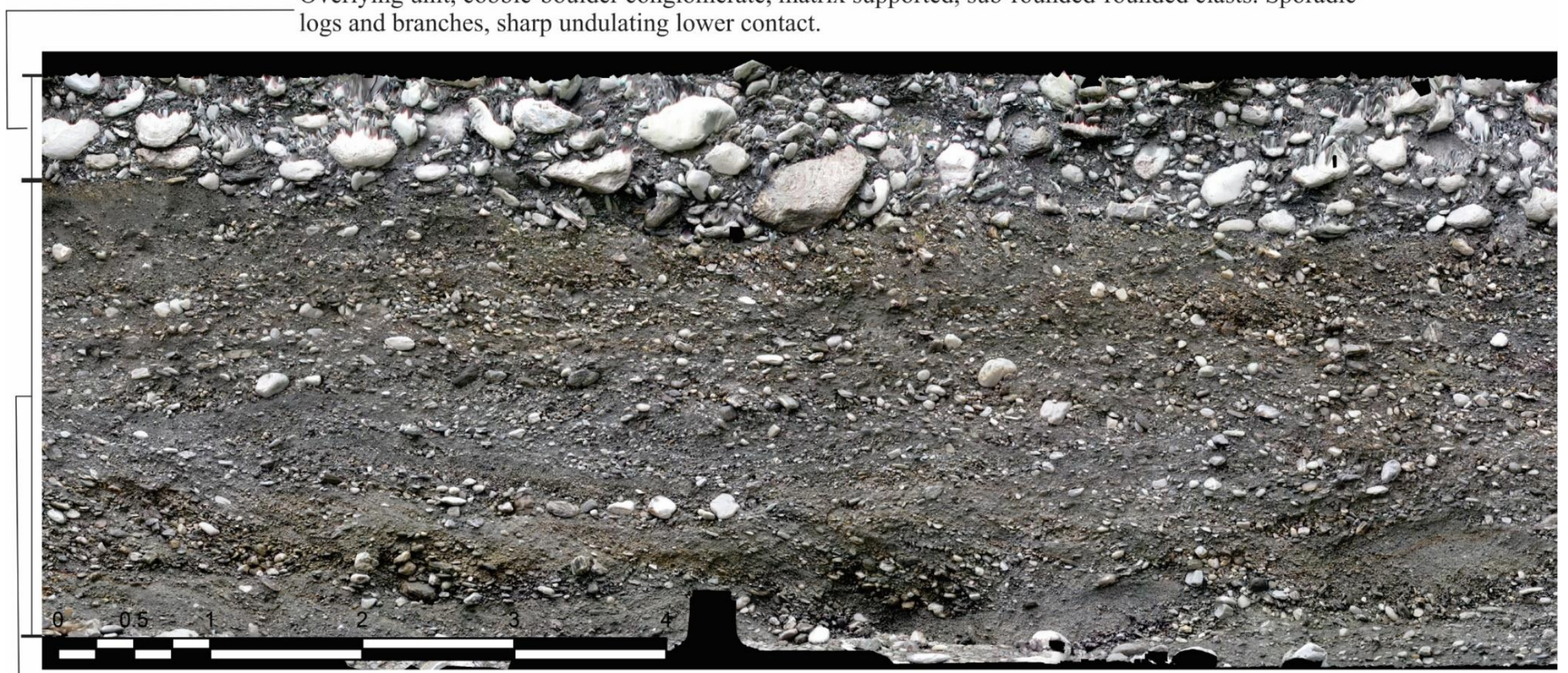

Pebble-cobble conglomerate unit, matrix-variable clast supported, sub-rounded-rounded clasts, medcoarse sand matrix. Clasts equal proportions Alpine Schist, semi-schist, Schist clasts typically smaller size. Variable 30-80 cm foreset, channel structures, local cross bedding, lower contact not observed.

Figure 3.26 Annotated ortho-photograph of the pebble-cobble conglomerate unit exposed in the Whataroa section. Scale in metres. 


\subsubsection{Key facies}

Three key facies are identified in the pebble-cobble conglomerate unit exposed in the Whataroa section (Table 13, Figure 3.27). These key facies are utilised in developing a facies scheme and depositional model.

Table 13 Facies identified from the pebble-cobble conglomerate unit exposed in the Whataroa section.

\begin{tabular}{|c|c|c|c|c|}
\hline Particle Grade & Facies code & Lithofacies & Bedding/Sedimentary Structures & Facies association \\
\hline \multicolumn{5}{|c|}{ Coarse sand-cobble } \\
\hline & $\mathrm{Gm}$ & $\begin{array}{l}\text { Grey-yellow, pebble to } \\
\text { cobble clasts, sand } \\
\text { matrix }\end{array}$ & $\begin{array}{l}\text { Metre scale, weakly bedded-massive } \\
\text { matrix supported, continuous outcrop } \\
\text { scale }\end{array}$ & $\begin{array}{l}\text { Dominant facies, alternating Gc, } \\
\mathrm{Sp}\end{array}$ \\
\hline & Gc & $\begin{array}{l}\text { Grey-yellow, pebble- } \\
\text { cobble clasts, minor Fe } \\
\text { staining }\end{array}$ & $\begin{array}{l}30-60 \mathrm{~cm} \text { scale, weakly bedded clast } \\
\text { supported conglomerate lenses }\end{array}$ & Minor facies, alternating $\mathrm{Gm}, \mathrm{Sp}$ \\
\hline & $\mathrm{Sp}$ & $\begin{array}{l}\text { Grey-brown, med- } \\
\text { coarse sand, minor Fe } \\
\text { staining }\end{array}$ & $\begin{array}{l}\text { 1-2 metre scale sand lenses, common } \\
\text { pebbles, local cross-bedding }\end{array}$ & Minor facies, alternating $\mathrm{Gc}, \mathrm{Gm}$ \\
\hline
\end{tabular}

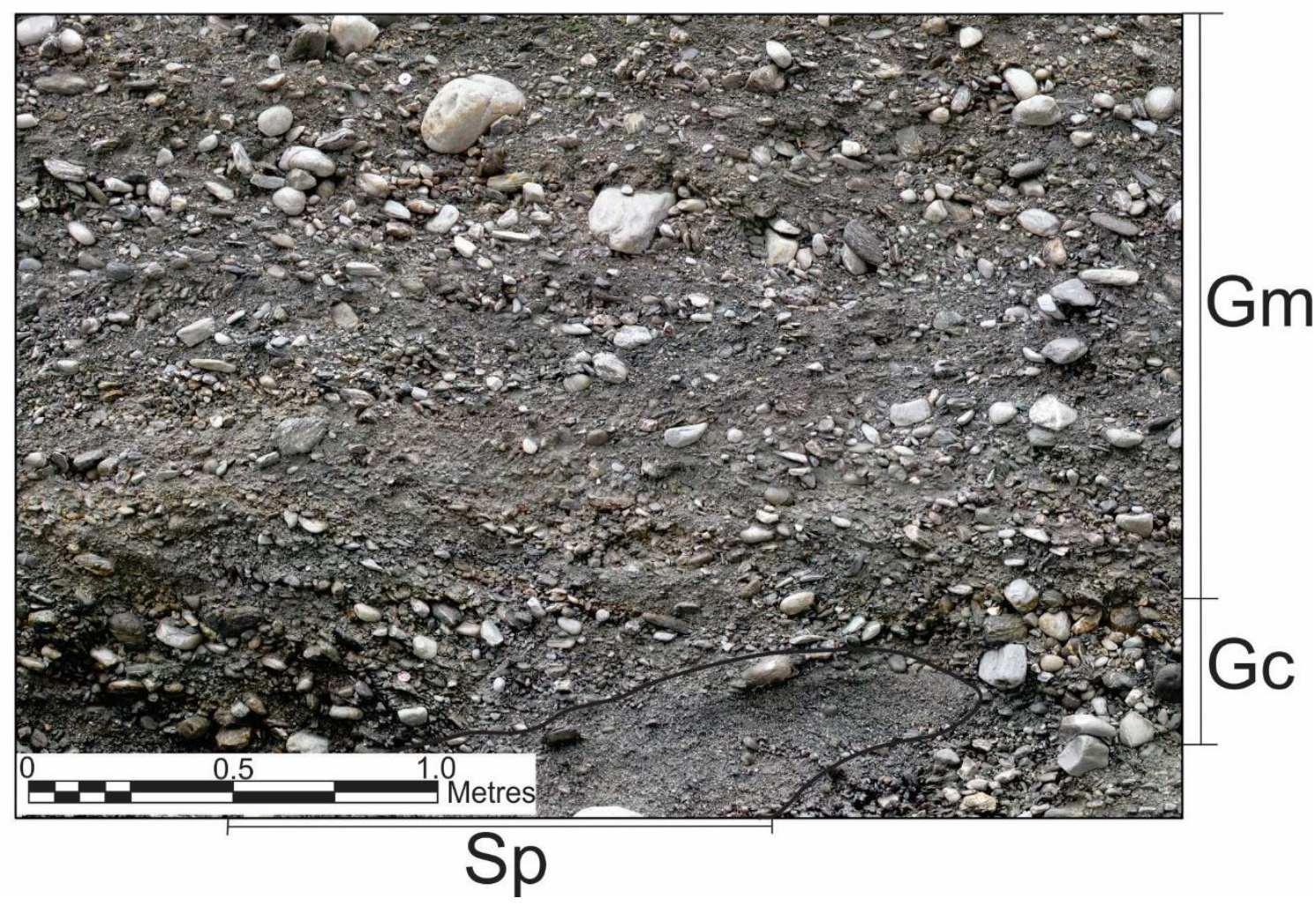

Figure 3.27 Annotated facies identified from the pebble-cobble conglomerate exposed at the Whataroa section.

\subsubsection{Facies interpretation}

The following interpretations are developed for facies identified in the pebble-cobble conglomerate unit described above. Interpretations are based upon the analysis of comparable sequences by Cant and Walker (1978), and Leopold et al. (2012). 
The pebble-cobble conglomerate unit is interpreted to be deposited in an aggradational fluvial environment, consistent with the interpretation of Klahn (2011). Common weakly bedded matrix and clast-supported gravels are interpreted as migratory bar deposits as part of a braided fluvial system, with common migratory channels forming Sp facies.

Table 14 Interpretation of lithofacies identified in the pebble-cobble conglomerate unit exposed at the Whataroa section.

\begin{tabular}{|clc|}
\hline Particle Grade Facies code & Lithofacies & \multicolumn{1}{c|}{ Interpretation } \\
\hline Coarse sand-cobble & Grey-yellow, pebble to & Fluvial migratory bar deposits \\
Gm & $\begin{array}{l}\text { cobble clasts, sand } \\
\text { matrix } \\
\text { Grey-yellow, pebble- } \\
\text { cobble clasts, minor Fe } \\
\text { staining } \\
\text { Grey-brown, med- } \\
\text { coarse sand, minor Fe } \\
\text { staining }\end{array}$ & Fluvial migratory bar deposits \\
& Sp & Braided fluvial channel deposit \\
\hline
\end{tabular}

\subsection{External outcrops and modern analogues}

Outcrop exposures in the Westland region do not comprehensively represent the suite of depositional environments associated with glacio-lacustrine sedimentation. Developing a depositional model solely based on these outcrop exposures would not be comprehensive. To improve this, published research is utilised to develop the facies schemes and depositional models.

\subsubsection{Ice contact Delta/Grounding line sedimentation}

The most prominent depositional environment for which no outcrops in Westland were logged is an ice contact delta/grounding line setting. Discussed by Carrivick and Tweed (2013), distal glacio-lacustrine sedimentation is far more likely to be preserved in the geological record, a finding consistent with observations here. To develop a facies scheme and depositional model for these settings, facies identified and interpreted by Bennett et al. (2002) and Lønne (1995) are utilised, outlined in Table 15.

Units deposited at or near the glacier grounding line are typically observed as complex, deformed diamict deposits (Bennett et al., 2002, Mager and Fitzsimons, 2007). This is attributed to the complex interplay of glacially influenced sediment supply, lake dynamics and glacio-tectonic deformation. 
Unsorted sediment is supplied at or near the grounding line largely as sub and en-glacial load, with minor input from side slopes and as supra-glacial load (Carrivick and Tweed, 2013). Though simplified in Table 15, diamict material can display a broad range of characteristics depending on depositional and post-depositional processes.

High sediment flux and glacio-tectonic deformation leads to instability of the ice contact delta, promoting slope failure and re-sedimentation of diamict material. Resedimented diamict material is observed to form coarse, massive debris rich sands in the upper slope environment, and sorted sands and silt deposits in the lower slope and distal environments (Bennett et al., 2002).

Table 15 Key facies identified from published research for the ice contact delta/grounding line depositional environment.

\begin{tabular}{|lllll||}
\hline Particle Grade & Facies code & Lithofacies & Bedding/Sedimentary Structures & Interpretation \\
\hline Gravel & Gs & $\begin{array}{l}\text { Silt-boulder clasts } \\
\text { boulder dominated }\end{array}$ & $\begin{array}{l}\text { Variable massive-graded, deformed } \\
\text { diamict }\end{array}$ & $\begin{array}{l}\text { Debris from rainout, ice-margin subglacial } \\
\text { release, deformed by glacio-tectonic processes }\end{array}$ \\
& Gms & $\begin{array}{l}\text { Silt-boulder clasts } \\
\text { matrix dominated }\end{array}$ & $\begin{array}{l}\text { Variable stratified, lenticular, deformed } \\
\text { diamict }\end{array}$ & $\begin{array}{l}\text { Debris from rainout, ice-margin sub-glacial } \\
\text { release, englacial conduits, variable re- } \\
\text { sedimentation by sub-aqeous debris flows in } \\
\text { upper slope }\end{array}$ \\
& Gg & $\begin{array}{l}\text { Fine silts-boulder } \\
\text { clasts }\end{array}$ & $\begin{array}{l}\text { Variable graded diamicts, laminated silts, } \\
\text { sands, gravels } \\
\text { Sand }\end{array}$ & $\begin{array}{l}\text { Upper-lower slope deposits, re-sedimented } \\
\text { diamict material by sub-aqeous debris flows, } \\
\text { turbidity currents }\end{array}$ \\
& Sm & $\begin{array}{l}\text { Fine-coarse sand, } \\
\text { sparse clasts }\end{array}$ & $\begin{array}{l}\text { Massive to weakly graded, locally } \\
\text { overlain by fine sands-silts }\end{array}$ & $\begin{array}{l}\text { Down-slope continum of Gg type debrite-- } \\
\text { turbidite deposit, depositing finer grain re- } \\
\text { sedimented diamict }\end{array}$ \\
\hline
\end{tabular}




\section{Chapter 4 Depositional models}

This chapter presents and discusses depositional models associated with the facies schemes developed in Chapter 3. Models are developed utilising glacio-lacustrine and glacio-fluvial outcrop exposures in Westland, as well as analogous sedimentary sequences from published research. Due to facies architecture changing markedly with the position of ice relative to the lake, both an ice contact and an ice distal model are developed for the Westland region.

Overall, 17 recurrent facies were identified from outcrop exposures and published analogues (Table 16). Each facies is given an interpretation, educated by facies characteristics and the comparison of facies with those in published research. Key publications used for facies interpretations include Lønne (1995), Bennett et al. (2002) and Mager and Fitzsimons (2007). The association of individual facies, and vertical facies successions observed in outcrop are used to construct the depositional models.

Table 16 Facies identified in Chapter 3, with facies code primary and secondary terminology outlined. Facies outcrop or published analogue outlined also.

\begin{tabular}{|cccc|}
\hline Facies Codes & Primary term & Secondary term & Outcrop/Published analogue \\
\hline Gravels & Matrix supported & & \\
Gm & Clast Supported & & Pebble-cobble Conglomerate: Whataroa \\
Gc & Plast Supported & Tilted & Peble-cobble Conglomerate: Whataroa \\
Gct & Conglomerate: Arahura Bridge \\
Gmt & Matrix supported & Tilted & Conglomerate: Arahura Bridge \\
Gmh & Stratified & Horizontally bedded & Sandy siltstone: Cesspool \\
Gs & Matrix supported & Stratified & Bennett et al., (2002) \\
Gms & Graded & & Bennett et al., (2002) \\
Gg & & & Bennett et al., (2002) \\
Sand & Massive & & Bennett et al., (2002) \\
Sm & Laminated & & Sandy siltstone: Cesspool \\
Sl & Cross-bedded & & Pebble-cobble Conglomerate: Whataroa \\
Sp & Clasts (sparse) & Tilted & Conglomerate: Arahura Bridge \\
Sct & Ripple bedded & & Sandy siltstone: Cesspool \\
Sr & Laminated & Clasts (sparse) & Sandy siltstone: Cesspool \\
Slc & & & \\
Fine Sand-Silt & Laminated & & Lower Waitangitaona Sections/Waitan-9 \\
Fl & Laminated & Ripple bedded & Lower Waitangitaona Sections/Waitan-9 \\
Flr & Mud Drape & & Lower Waitangitaona Sections/Waitan-9 \\
Fmd & &
\end{tabular}




\subsection{Ice contact model}

Facies identified from outcrop and published analogues, associated with ice contact sedimentation are summarised below, with facies interpretations presented (Table 17).

Table 17 Integrated facies scheme developed from outcrop and published analogues for an ice contact depositional environment.

\begin{tabular}{|c|c|c|c|c|}
\hline Particle Grade & Facies cod & e Lithofacies & Bedding/Sedimentary Structure & Interpretation \\
\hline \multicolumn{5}{|l|}{ Gravel } \\
\hline & Gs & $\begin{array}{l}\text { Silt-boulder clasts } \\
\text { boulder dominated }\end{array}$ & $\begin{array}{l}\text { Variable massive-graded, deformed } \\
\text { diamict }\end{array}$ & $\begin{array}{l}\text { Debris from rainout, ice-margin subglacial } \\
\text { release, deformed by glacio-tectonic processes }\end{array}$ \\
\hline & Gms & $\begin{array}{l}\text { Silt-boulder clasts } \\
\text { matrix dominated }\end{array}$ & $\begin{array}{l}\text { Variable stratified, lenticular, } \\
\text { deformed diamict }\end{array}$ & $\begin{array}{l}\text { Debris from rainout, ice-margin sub-glacial } \\
\text { release, englacial conduits,variable re- } \\
\text { sedimentation by sub-aqeous debris flows in } \\
\text { upper slope }\end{array}$ \\
\hline & Gg & $\begin{array}{l}\text { Fine silts-boulder } \\
\text { clasts }\end{array}$ & $\begin{array}{l}\text { Variable graded diamicts, laminated } \\
\text { silts, sands, gravels }\end{array}$ & $\begin{array}{l}\text { Upper-lower slope deposits, re-sedimented } \\
\text { diamict material by sub-aqeous debris flows, } \\
\text { turbidity currents }\end{array}$ \\
\hline \multicolumn{5}{|l|}{ Sand } \\
\hline & $\mathrm{Sm}$ & $\begin{array}{l}\text { Fine-coarse sand, } \\
\text { sparse clasts }\end{array}$ & $\begin{array}{l}\text { Massive to weakly graded, locally } \\
\text { overlain by fine sands-silts }\end{array}$ & $\begin{array}{l}\text { Down-slope continuum of Gg type debrite-- } \\
\text { turbidite deposit, depositing finer grain re- } \\
\text { sedimented diamict }\end{array}$ \\
\hline \multicolumn{5}{|l|}{ Fine sand-clay } \\
\hline & $\mathrm{Fl}$ & $\begin{array}{l}\text { Dark-light grey, } \\
\text { coarse to fine } \\
\text { laminated silts with } \\
\text { rare clasts }\end{array}$ & $\begin{array}{l}\text { Normally graded bedding, } 5-80 \mathrm{~mm} \\
\text { bed thickness }\end{array}$ & $\begin{array}{l}\text { Glacio-lacustrine deposit, formed by density } \\
\text { flows exiting the delta/subaqeous meltwater } \\
\text { conduit, lodestones deposited by ice rafting }\end{array}$ \\
\hline & Flr & $\begin{array}{l}\text { Dark-light grey, } \\
\text { coarse silts with x } \\
\text { lamination }\end{array}$ & $\begin{array}{l}\text { Climbing ripples, cross beds, mud } \\
\text { drapes, } 10-200 \mathrm{~mm} \text { bed thickness }\end{array}$ & $\begin{array}{l}\text { Glacio-lacustrine deposit, formed by density } \\
\text { flows of greater magnitude than } \mathrm{Fl} \text { events }\end{array}$ \\
\hline & Fmd & $\begin{array}{l}\text { Light grey, fine silt } \\
\text { to clay }\end{array}$ & $\begin{array}{l}\text { Draping Flr bedforms, } 1-5 \mathrm{~mm} \text { bed } \\
\text { thickness }\end{array}$ & $\begin{array}{l}\text { Glacio-lacustrine deposit formed by } \\
\text { suspension settling }\end{array}$ \\
\hline
\end{tabular}

Of the seven ice contact facies in the facies scheme presented above, three are identified from the laminated siltstone units at the lower Waitangitaona section outcrops, and Waitan-9 field sites. Fl, Flr and Fmd facies are observed to be vertically stacked in field outcrops, representing alternating depositional processes occurring in the distal lacustrine environment. As neither laminated siltstone unit is underlain or overlain by any recognisable glacio-lacustrine units, vertical facies successions cannot be used to evaluate the migration of laterally adjacent environments however. As a result, published research is utilised.

To inform the depositional environment proximal to the ice-front, four key facies are identified from the published analogue of Bennett et al. (2002). In this research, comprehensive exposures of proximal glacio-lacustrine facies allowed a detailed facies scheme to be developed for this environment. The vertical facies associations observed by Bennett et al. (2002) are therefore utilised to develop this portion of the model. Facies interpretations and associations are presented graphically through a schematic depositional model for ice contact sedimentation (Figure 4.1). 


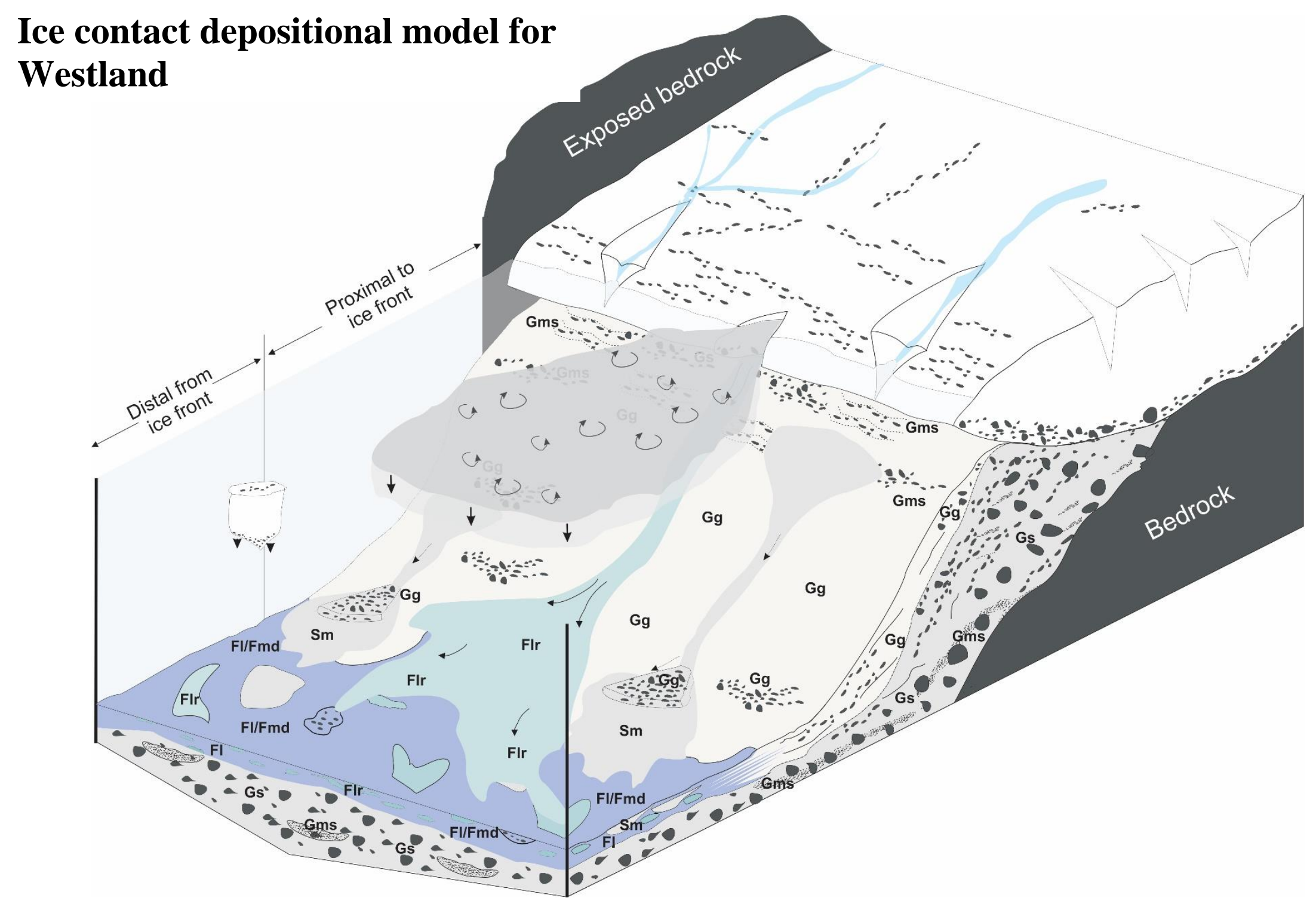

Figure 4.1 Ice contact depositional model, with facies annotations developed for the ice contact facies scheme. Note glacier is grounded on bedrock, with abundant Gs facies diamict produced where glacier detaches from bedrock. Note floating ice tongue. 
The ice contact depositional model is divided into two regions, due to the presence of distinctly different facies assemblages:

- Deposition proximal to the ice front.

- Deposition distal from the ice front.

\subsubsection{Deposition proximal to the ice front:}

Proximal to the ice front, coarse-grained sediment is supplied from two sources; unsorted sub-glacial material deposited at the terminus, and outwash material (including sub, supra and englacial load) supplied by glacial outflow (Lønne, 1995). Deposition in this region is influenced by the position and behaviour of the ice mass, as well as proglacial lake dynamics.

In the facies scheme and depositional model developed (Table 17, Figure 4.1), unsorted material supplied by sub-glacial release and rainout forms facies Gs. This facies is mantled onto bedrock or underlying diamict and associated with facies Gms. Facies Gms is comparable to facies Gs, though sub-glacial material has undergone some hydrological sorting to produce stratified or lenticular diamicts.

Facies Gg comprises graded sands, silts and diamicts deposited on the glacio-lacustrine delta slope by re-sedimentation of Gs and Gms type diamicts and outwash material. Resedimentation occurs via sub-aqueous debris flows to produce debrite type deposits upslope, and graded turbidite deposits down-slope (Bennett et al., 2002). Resedimentation events may be triggered by glacier meltwater events, tectonic or glaciotectonic deformation, delta slope instability as well as dynamic glacier and pro-glacial lake processes (Bennett et al., 2002). Gg type re-sedimented diamict material is the major facies associated with the glacio-lacustrine delta, though Gg type deposits may be observed more distally from the delta during large sediment transport events.

\subsubsection{Deposition distal from the ice front}

Distal from the ice front, sediment is transported by two mechanisms; sand sized sediment transported as density flows, and fine sediments (clay-silt) transported by meltwater plumes and deposited via suspension settling (Powell, 1990). These mechanisms transport sediment derived from the glacier meltwater outflow, and are therefore influenced by the frequency of large outflow events, as well as the volume of sediment supplied from the outflow (Lønne, 1995). 
In the facies scheme developed, $\mathrm{mm}$ to $20 \mathrm{~cm}$ scale, normal graded beds (Fl, Flr facies) are interpreted as density flow deposits. Outcrop evidence from the laminated siltstone unit at lower Waitangitaona section showed these deposits varying in thickness, from coarser cross-bedded, normally graded deposits (Flr facies), to thinner laminated normally graded deposits (Fl facies). Varying bed thickness is interpreted to represent varying magnitudes of density flow events, with larger fluid and sediment transport events producing higher flow regime, coarser grained Flr facies. Density flows are interpreted to be formed by elevated fluid discharge events from the glacier and catchment, as well as due to failure events on the glacio-lacustrine delta (Bennett et al., 2002).

Sand sized, massive to weakly graded deposits deposited distal from the ice-front are classified as Sm facies (Bennett et al., 2002). In published analogues, Sm facies are observed as metre scale deposits with varying clast content, deposited by turbidity currents as the downslope continuum of a Gg type debrite deposit. Coarse-grained material can also be transported distally from the ice-front as ice rafted debris (IRD). The presence of IRD in glacio-lacustrine sedimentary sequences requires glacier ice to have been terminated directly into the lake at the time of deposition, therefore being a key facies in identifying ice contact depositional environments.

\subsubsection{Additional processes}

A number of additional processes are included in the depositional model developed for ice contact sedimentation in Westland (Figure 4.1):

- Debris cover on the glacier surface: Presently the retreating Franz Josef and Fox Glaciers host an increasing volume of debris cover (Brook et al., 2017). Supraglacial debris derived from steep valley walls is shown in the model developed, providing an additional source of coarse-grained material to the grounding line.

- Fluid discharge off the glacier surface: Presently, West Coast glaciers display fluid runoff on glacier surface during characteristic Westland precipitation events associated with westerly airflow over the Southern Alps. As a result, supra-glacial fluid conduits are displayed in Figure 4.1. This fluid discharge may produce meltwater plumes, as well as hydrologically sort grounding line sediment. 


\subsection{Ice distal model}

Facies identified from outcrop and published analogues associated with ice distal sedimentation are summarised below (Table 18).

Table 18 Integrated facies scheme developed from outcrop and published analogues for an ice distal depositional environment.

\begin{tabular}{|c|c|c|c|c|}
\hline Particle Grade & Facies code & e Lithofacies & Bedding/Sedimentary Structures I & nterpretation \\
\hline \multicolumn{5}{|c|}{ Coarse sand-cobble } \\
\hline & Gct & $\begin{array}{l}\text { Grey-yellow, pebble } \\
\text { to cobble clasts }\end{array}$ & $\begin{array}{l}\text { Massive discontinous clast supported } \\
\text { lenses, dipping } 20-25^{\circ}, 20-50 \mathrm{~cm} \text { thick }\end{array}$ & $\begin{array}{l}\text { Clast rich mass movement deposits, forming } \\
\text { lobate foresets in a a prograding Gilbert type } \\
\text { delta }\end{array}$ \\
\hline & Gmt & $\begin{array}{l}\text { Grey-yellow, pebble- } \\
\text { cobble clasts, sand } \\
\text { matrix }\end{array}$ & $\begin{array}{l}\text { Weakly bedded matrix supported } \\
\text { lenses, dipping } 20-25^{\circ}, 40-60 \mathrm{~cm} \text { thick }\end{array}$ & $\begin{array}{l}\text { Sand and clast rich mass movement deposits, } \\
\text { forming lobate foresets in a prograding Gilbert } \\
\text { type delta }\end{array}$ \\
\hline & $\mathrm{Gmh}$ & $\begin{array}{l}\text { Pebble-cobble clasts, } \\
\text { sand matrix }\end{array}$ & $\begin{array}{l}\text { Weak horizontal bedding, matrix } \\
\text { supported, } 20-40 \mathrm{~cm} \text { thick }\end{array}$ & $\begin{array}{l}\text { Clast rich mass movement deposits, deposited } \\
\text { on a low angle bed-slope }\end{array}$ \\
\hline & $\mathrm{Gm}$ & $\begin{array}{l}\text { Grey-yellow, pebble } \\
\text { to cobble clasts, } \\
\text { sand matrix }\end{array}$ & $\begin{array}{l}\text { Weakly bedded, matrix supported, } \\
\text { metre scale bed thickness }\end{array}$ & Fluvial migratory bar deposits \\
\hline & Gc & $\begin{array}{l}\text { Grey-yellow, pebble- } \\
\text { cobble clasts, minor } \\
\text { Fe staining }\end{array}$ & $\begin{array}{l}\text { Weakly bedded, clast supported, metre } \\
\text { scale bed thickness }\end{array}$ & Fluvial migratory bar deposits \\
\hline & Set & $\begin{array}{l}\text { Light grey-brown, } \\
\text { fine to medium sand } \\
\text { with clasts }\end{array}$ & $\begin{array}{l}\text { Weakly bedded, dipping } 20-25^{\circ}, 5-50 \\
\mathrm{~cm} \text { thick }\end{array}$ & $\begin{array}{l}\text { Density underflow deposit, mantling Gct and } \\
\text { Gmt lobe facies }\end{array}$ \\
\hline \multicolumn{5}{|l|}{ Sand } \\
\hline & $\mathrm{S} 1$ & $\begin{array}{l}\text { Light grey-brown, } \\
\text { fine to medium } \\
\text { sands }\end{array}$ & $\begin{array}{l}\text { Horizontal lamination, } 1-30 \mathrm{~cm} \text { bed } \\
\text { thickness }\end{array}$ & $\begin{array}{l}\text { Sand dominated density flows deposited onto } \\
\text { a low angle bed-slope }\end{array}$ \\
\hline & $\mathrm{Sr}$ & $\begin{array}{l}\text { Light grey-brown, } \\
\text { fine to medium } \\
\text { sands }\end{array}$ & $\begin{array}{l}\text { Ripple, dune and anti-dune bedforms, } 1 \\
5 \mathrm{~cm} \text { bed thickness }\end{array}$ & $\begin{array}{l}\text { Density flows/currents with variable flow } \\
\text { regimes deposited on a low angle bed-slope }\end{array}$ \\
\hline & Slc & $\begin{array}{l}\text { Light grey-brown, } \\
\text { fine to medium } \\
\text { sands with clasts }\end{array}$ & $\begin{array}{l}\text { Horizontal lamination, } 1-30 \mathrm{~cm} \text { bed } \\
\text { thickness }\end{array}$ & $\begin{array}{l}\text { Sand/clast dominated density flows deposited } \\
\text { on a low angle bed-slope }\end{array}$ \\
\hline & $\mathrm{Sp}$ & $\begin{array}{l}\text { Grey-brown, med- } \\
\text { coarse sand, minor } \\
\text { Fe staining }\end{array}$ & $\begin{array}{l}\text { Cross/foreset bedded, 1-2 metre sand } \\
\text { lenses }\end{array}$ & Braided fluvial channel deposit \\
\hline
\end{tabular}

Ten key facies associated with ice distal sedimentation are identified from outcrop exposures in South Westland, (Table 18), with the majority identified from the conglomerate and sandy siltstone units exposed at the Arahura Bridge and Cesspool Sections. The vertical facies succession observed at these sites is used to develop the delta slope and delta toe region of the depositional model (Figure 4.2).

Facies Fl, Flr, Fmd and Sm described in the ice contact facies scheme are interpreted to be deposited downstream of the shoreline in the ice distal depositional model.

Lithofacies descriptions developed for the ice contact facies scheme are unchanged for deposition in the ice distal model, with the omission of lonestone clasts in Fl facies deposits, due to clast transport via ice rafting being inhibited. Facies interpretations and associations are presented graphically through the development of a schematic depositional model for ice distal sedimentation (Figure 4.2). 


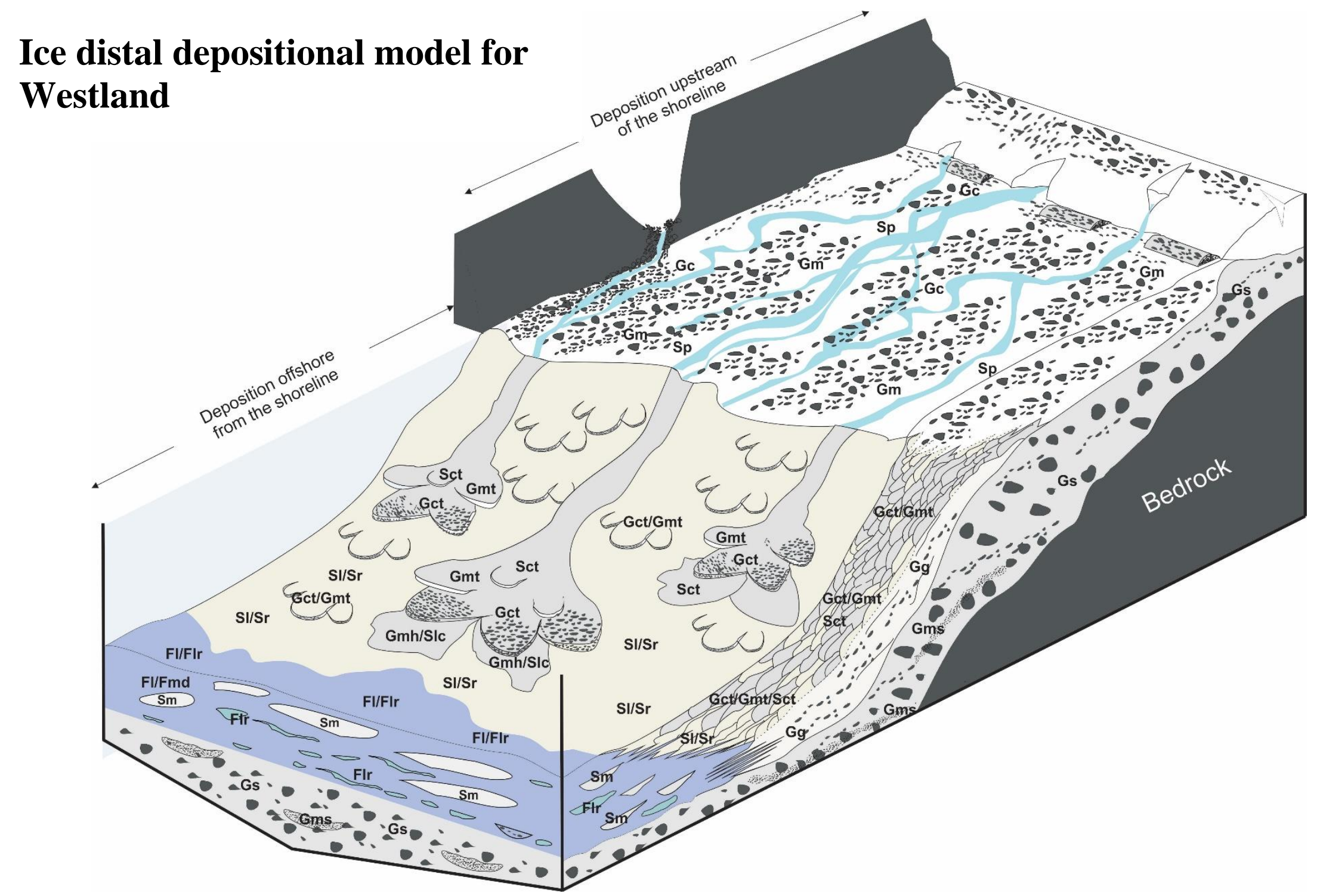

Figure 4.2 Ice distal depositional model, with facies annotations developed for the ice distal facies scheme. Note influx of sediment supplied from side catchments, presence of remnant delta lobe deposits, along with active prograding lobes forming lacustrine delta. 
The ice distal depositional model is divided into two regions, based on characteristic facies assemblages:

- Deposition proximal and upstream of the shoreline.

— Deposition offshore from the shoreline.

\subsubsection{Deposition proximal and upstream of the shoreline}

In the ice distal model, glacially derived sediment undergoes reworking across a fluvial plain upstream of the lake shoreline. With high sediment flux supplied to the fluvial plain, this system deposits aggradational terrace and bar units (Carrivick and Rushmer, 2009), classified as Gc, Gm and Sp facies. Fluvial reworking of glacial or colluvial sediment alters clast morphology, removing surface features and rounding clasts with transport distance (Hambrey and Ehrmann, 2004).

This model also accounts for sediment input from side catchments which drain onto the fluvial plain. Sediment flux from side catchments is interpreted as significant, as sediment can accumulate in these catchments when their outlets are blocked by the main large glacier, to be released once the glacier recedes upstream of the side catchment.

At the lake shoreline a prograding lacustrine delta forms. Coarse-grained sediment transported to the delta from fluvial channels produces lobate deposits at or near the angle of repose (Facies Gct, Gmt), formed by gravitational deposition on the prograding delta face (Bennett et al., 2002). As fluvial channel systems migrate laterally across the delta face, deposition of Gct and Gmt facies will shift laterally, allowing these facies to be dominant in forming the delta slope. This facies architecture is observed in the conglomerate unit outcropping at the Arahura Bridge and Cesspool sections.

Toward the delta toe, facies architecture is interpreted to change as the delta slope angle decreases to near horizontal. Outcrop evidence from the Cesspool section shows the delta toe to be a sand dominated environment, with density flows off the delta producing stratified sand deposits (Facies $\mathrm{Sl}$ ). The presence of upper flow regime sedimentary structures demonstrates that the density flows can be vigorous in remobilising and depositing sediment to produce Sr facies identified in outcrop (Figure 3.23). As the delta toe prograde, coarse-grained or clast rich material is transported further downslope, producing Gmh and Slc type deposits, which overlie Sl and Sr facies at the Cesspool section. The transport of clast rich material toward, or past the delta toe 
could also be achieved by large mass movement events, mobilising large volumes of sediment over a short period.

\subsubsection{Deposition offshore from the shoreline}

Deposition distal from the shoreline is dominated by density flow deposits ( $\mathrm{Fl}, \mathrm{Flr}$ facies). Additionally, sediment input from suspension settling will produce fine-grained Fmd deposits, though for visual simplicity this process is not displayed in Figure 4.2.

Fine to coarse sand deposits may be present in the distal lacustrine environment, with large sub-aqueous debris flow events or mass movement events producing $\mathrm{Sm}$ or Slc deposits. These deposits are argued to present an infrequent mode of sediment flux to the distal environment, being more common proximal to the delta. As the delta system progrades, sand and gravel facies will begin to overlie Fl and Flr facies, producing a stacked vertical sequence of increasing proximal delta facies.

\subsection{Relationship between ice contact and ice distal models}

The ice contact and ice distal models represent two stages in the temporal evolution of a pro-glacial lake system during ice retreat, producing a diverse range of facies assemblages. The evolution of the pro-glacial lake system occurring between the two stages represented by the models is discussed below:

The transition between an ice contact and ice distal depositional environment is driven by two factors, ice mass loss and sediment flux (Lønne, 1995). Glacier mass loss results in down wasting of the glacier surface, as well as terminus retreat. Terminus retreat acts to provide accommodation space in front of the glacier for sediment to accumulate. As sediment is supplied and accumulates at the grounding line an ice contact delta will develop (Lønne, 1995). Should sufficient sediment build up at the delta, or the lake level decrease relative to the glacier terminus, the glacier will begin to terminate upstream of the pro-glacial lake, opposed to directly into the lake (Carrivick and Tweed, 2013). This represents an important transition in the development of a pro-glacial lake system.

As the glacier terminus retreats upstream of the lake, sediment supplied at the grounding line undergoes transport across a fluvial outwash plain before entering the lake, causing the reworking of clasts and development of a prograding lacustrine delta. 
Sedimentary facies deposited off the delta front are shown to overtop the remnant ice contact delta deposits in the model.

With high rates of sediment flux originating from the main glacial valley, as well as deglaciated side catchments, the fluvial and lacustrine delta system will prograde down valley. Delta facies will begin to overtop distal lacustrine deposits as the system develops further, as observed at the Cesspool section. With ongoing glacial retreat, the fluvial system is interpreted to prograde down-valley to overtop, or erode into lacustrine delta deposits. 


\section{Chapter 5 Deep Fault Drilling Project 2}

This chapter presents results from the analysis of a sedimentary sequence overlying schist bedrock, which was recovered by DFDP-2. Samples are derived from the depth interval 0-240 metres measured depth (MD), from boreholes DFDP-2A and DFDP-2B. On-site analysis of the sedimentary sequence identified a number of lithological units as drilling progressed down-hole*. Depth intervals of the units were assigned on site, and later confirmed through analysis of samples recovered. Results are presented with the sedimentary sequence distinguished into depth intervals, representing key lithological units.

Downhole contamination of DFDP-2 cuttings samples may be present due to rotary drilling and sample recovery methods. In performing grain-size analysis on drill-cutting samples, the grain-size distribution may not reflect the true grain-size distribution of the unit. In silt-sandstone samples, the effect of drilling on grain-size distribution is thought to be minimal, as grains are unlikely to be frequently fractured during drilling. Absolute values of grain-size volume percent should be treated with some caution however.

In coarser-grained or clast rich units recovered by rotary drilling, the potential for grainsize and grain shape results to be skewed is greater. On-site analysis of samples noted a prevalence of un-fractured, sub-rounded clasts in conglomerate units, with very large pebble clasts recovered un-fractured (Figure 5.1). In units with clasts larger than $\sim 4-5$ centimetres, the sample grain-size is unlikely to reflect the true unit grain-size. This is interpreted to have minimal influence on the interpretation of units drilled however.

\subsection{Depth interval 0-59 metres MD}

Depth interval 0-59 metres MD recovered cuttings samples from borehole DFDP-2A, and cuttings/wet sediment samples from DFDP-2B. The gross lithology of the unit drilled is a pebble-cobble conglomerate (Figure 5.1, Figure 5.2). Correlative outcrops of 
the unit are observed in river terraces upstream of the drill-site, therefore section descriptions were taken from outcrops where possible.

\section{Section Images}
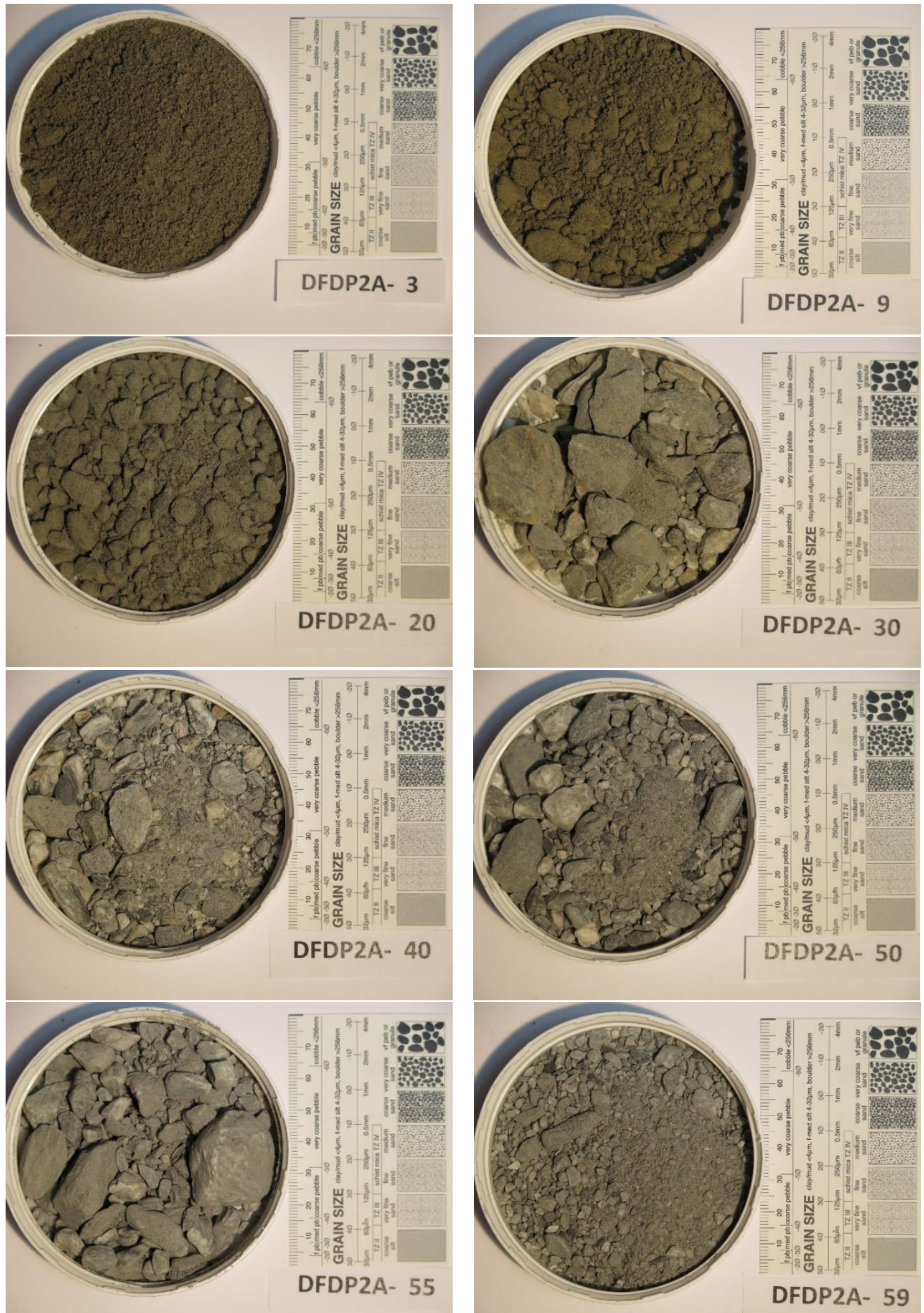

Figure 5.1 Photographs of cuttings samples collected from 0-59 metres MD, DFDP-2A. Numbers on bottom right of images denotes sample collection depth $(3,9,20,30,40,50,55,59$ metres MD). Additional images available in Digital Appendix 3. 


\section{Section Log}

A section log is produced for the pebble-cobble conglomerate unit, herein referred to as the upper gravels unit. Sample logging was carried out by the DFDP-2 site geologists during drilling, forming the unit descriptions shown here (Figure 5.2).

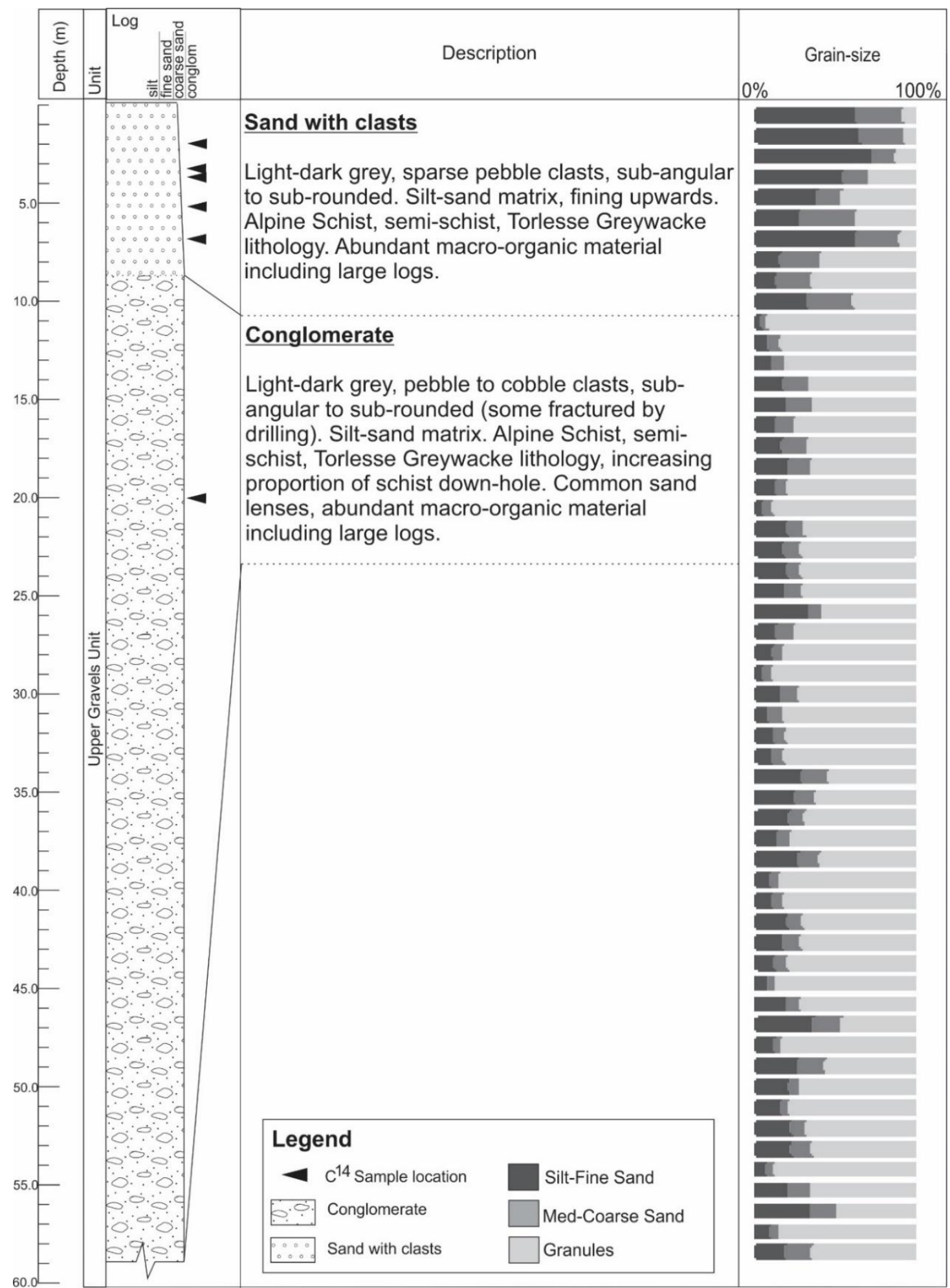

Figure 5.2 Section Log for interval 0-59 metres MD, with grain-size displayed. Grain-size was measured via sieve stack, during DFDP-2 drilling. Data supplied by Simon Cox. Summary data available in Appendix A5. 


\section{Results}

\section{Grain-size data}

Sieve stack grain-size measurements taken at metre intervals down-hole (Figure 5.2) show that underlying $\sim 10$-metres of silty sand is $\sim 49$-metres of relatively uniform pebble to cobble conglomerate. Within this unit, local variations in matrix and clast percentages were observed, though samples consistently contain greater than $\sim 50 \%$ clasts.

Grain-size profiles of the silt-sand sized matrix (Figure 5.3) show matrix grain-size to be dominated by the medium to coarse silt fraction, with variable unimodal to multimodal distributions. There is no systematic variation in matrix grain-size observed throughout this unit.
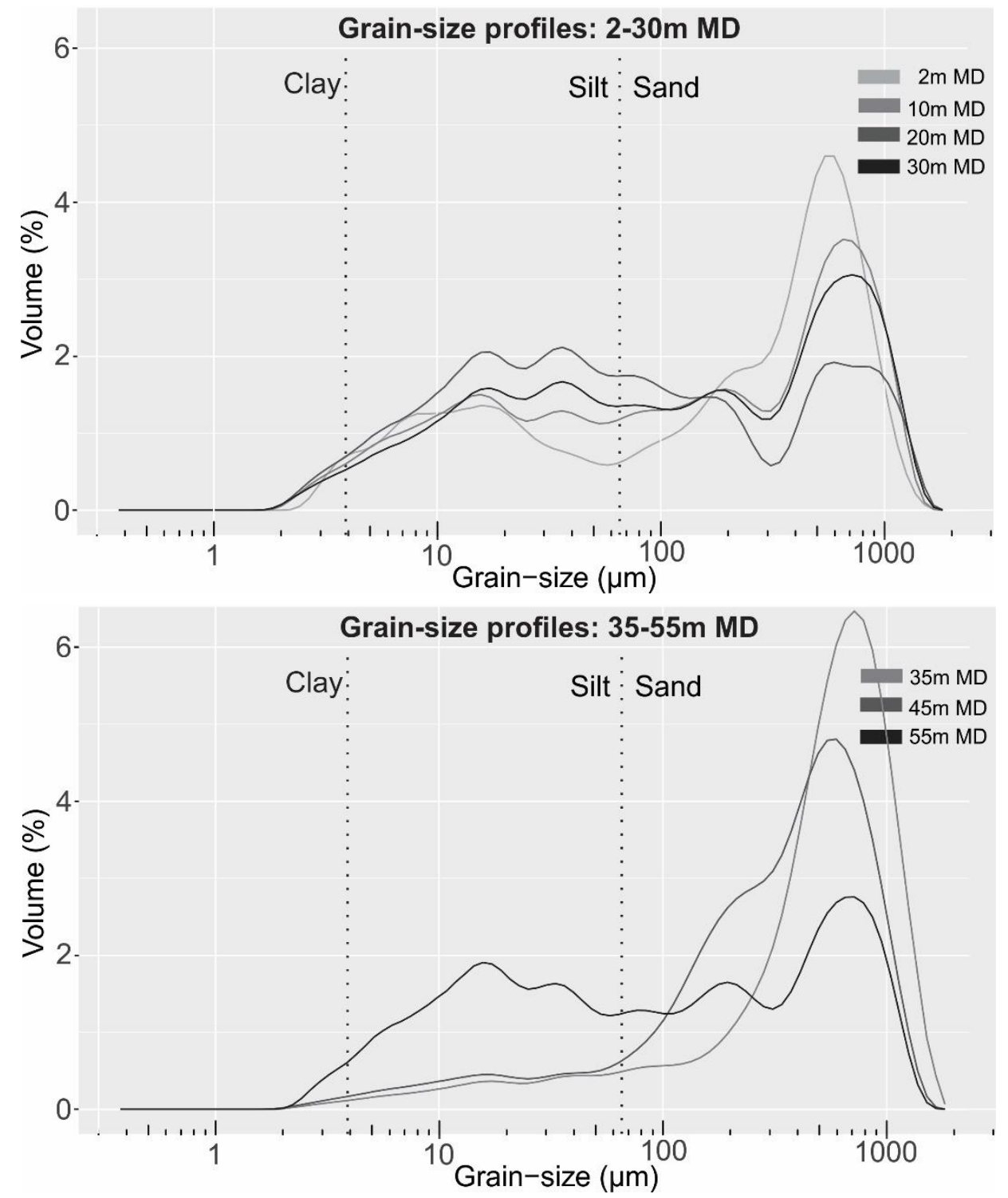

Figure 5.3 Matrix grain-size profiles of samples recovered from the upper gravels unit, DFDP-2A, 2-55 metres MD. Summary data available in Appendix A4. Full datasets available in Digital Appendix C. 


\section{Clast analysis}

Clast lithology in the upper gravels unit is comparable to the modern bed-load of the Whataroa River, consisting minor amphibolite grade schist, and equal proportions of biotite zone schist, greenschist facies semi-schist, and sub-greenschist facies sandstone. On-site analysis showed un-fractured clasts being sub-angular to sub-rounded in shape, with an increasing proportion of schist clasts present lower in the section (Cox et al., 2016).

\section{${ }^{14}$ C Chronology}

A number of macro-organic samples were collected from correlative outcrops to the upper 10 metres of the upper gravels unit. ${ }^{14} \mathrm{C}$ ages range from present to $\sim 700 \mathrm{cal}$. yr $\mathrm{BP}$, indicating that at least the upper part of the unit has been deposited in the last 1000 years*. A single ${ }^{14} \mathrm{C}$ sample was submitted from 19.9 metres MD (DFDP-2B), returning an age of $678 \pm 22$ cal. yr BP. Raw ${ }^{14} \mathrm{C}$ data is available in Appendix A1.

An unconformity is inferred to exist in the unit, with the interval $\sim 20$ to 59 metres MD being $\sim 10-15 \mathrm{kyr}$ in age. This is based on the stratigraphic position of uplifted exposures of $\sim 10-15$ kyr gravels upstream of the drill-site, which are of comparable grain-size to the gravel unit drilled through (Cox et al., 2016).

\subsubsection{Facies comparison}

Though facies associations cannot be easily examined from cuttings samples, lithofacies descriptions developed from outcrop exposures (Chapters 3, 4) are used to determine key facies in units drilled.

Clast size and shape resemble those identified in the pebble-cobble conglomerate unit exposed at the Whataroa section, where facies Gc, Gm and Sp were defined. Clast rich intervals in the upper gravels unit are interpreted as Gc or Gm facies (Figure 5.4). Sand rich, clast poor intervals are interpreted as metre scale sand lenses (Sp facies).

Facies Gc and Gm dominate the 10-59 metre MD interval, with facies Sp being comparatively minor. It is possible that fine-grained sand samples interpreted as Sp facies are simply clast-rich intervals which have undergone artificial grain-size reduction due to drilling. As a result, the overall characteristics of the unit, opposed to the specific facies identifications are used to interpret the unit depositional environment. 

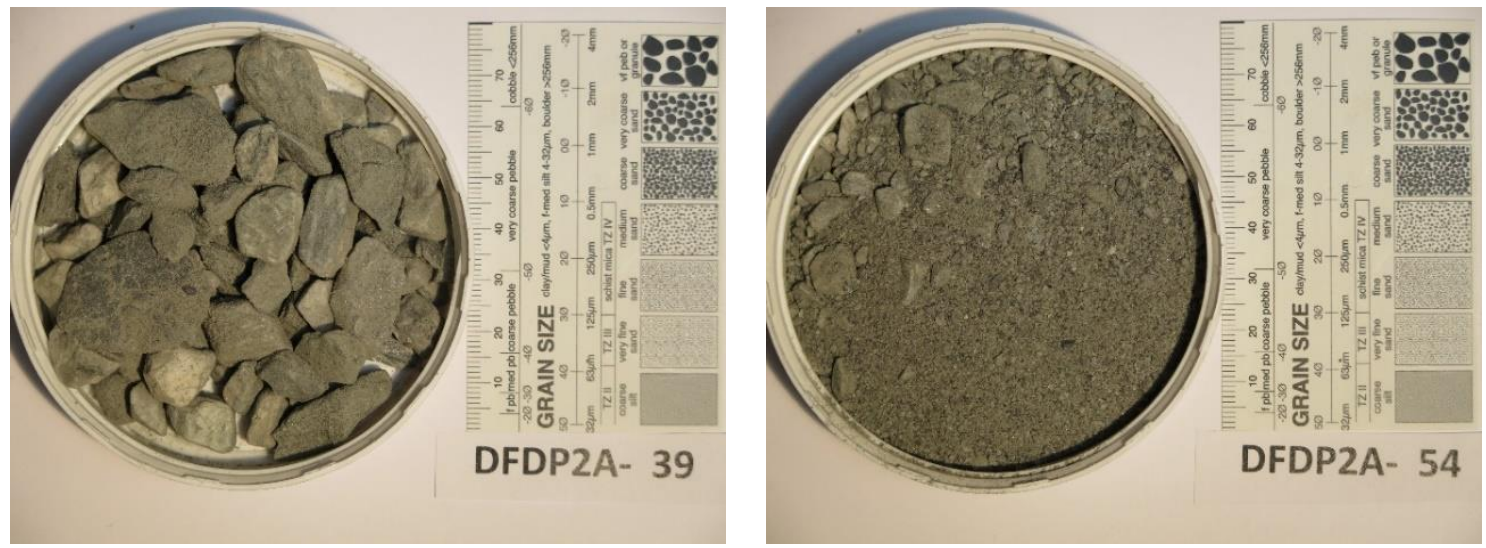

Figure 5.4 Cuttings photos from interval 0-59 m MD, with Gc/Gm facies (left) and Sp facies (right) identified from cuttings samples.

\subsubsection{Interpretation}

Correlative outcrops of the upper gravels unit are interpreted as aggradational fluvial deposits in previous studies (Klahn, 2011). Analysis of the correlative outcrops in this study observed characteristic channel and bar deposits, associated with fluvial depositional environments. In drilling samples, clast size and shape is comparable to that observed in outcrop, though no clasts larger than 4-5 centimetres were recovered in drilling samples.

Due to these factors, the upper gravels unit intercepted from 0-59 metres MD is interpreted as alluvial gravels deposited by an aggrading fluvial system. The sand with clasts unit observed from 0-10 metres MD is interpreted to have formed from the upper gravels unit, which has undergone pedogenic breakdown.

\subsection{Depth interval 59-80 metres MD}

Depth interval 59-80 metres MD recovered cuttings samples samplings at 1-metre intervals, and wet sediment samples at 2-3 metre intervals from DFDP-2A and 2B respectively.

The gross lithology of the unit recovered is an upward coarsening fine-medium sandstone. The transition between the overlying upper gravels unit and the fine-medium sandstone unit occurred within a 1-metre sampling interval, marked by an absence of pebble-cobble clasts. The contact between these two units is therefore interpreted to be abrupt. A section log of the fine-medium sandstone unit is presented in Figure 5.5, with mean matrix grain-size and standard deviation displayed down-section. 


\subsubsection{Section log}

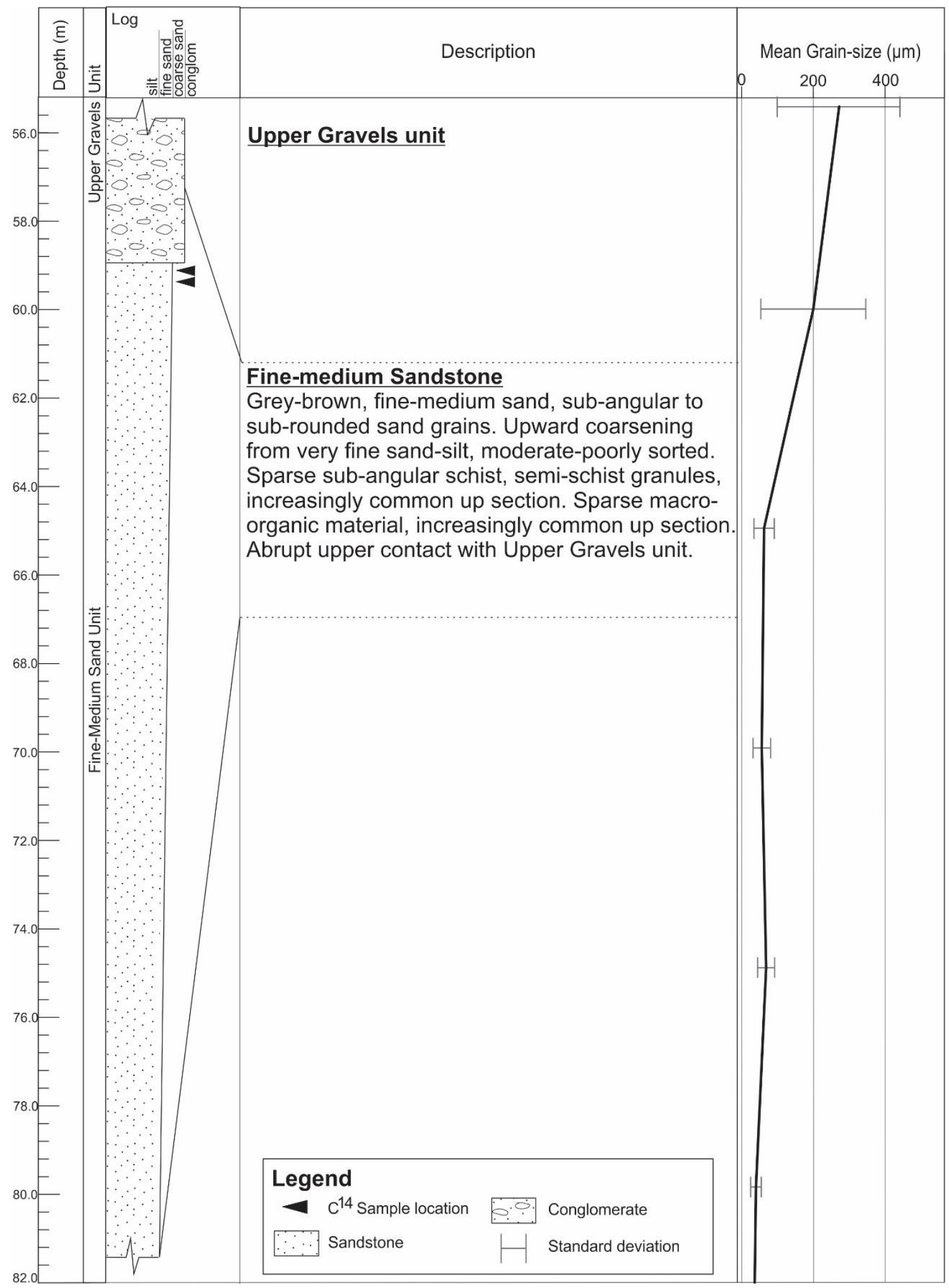

Figure 5.5 Section log for the interval 59-80 metres MD. Matrix mean grain-size, and standard deviation (bar range) plotted down section. Summary grain-size data available in Appendix A4. 


\subsubsection{Results}

\section{Grain-size data}

Mean grain-size measurements display a progressive upward coarsening trend from 80 to $\sim 65$ metres MD (Figure 5.5). Standard deviation increases upwards through this interval, attributed to a decrease in sediment sorting. Mean grain-size shows a significant increase proximal to the upper contact (60-65 metres MD) of the finemedium sandstone unit, accompanied by an increase in standard deviation.

Grain-size profiles (Figure 5.6) show a progressive shift from a silt to sand dominated environment from 80 to 60 metres MD. With increasing grain-size up section, a shift from bimodal and unimodal profiles (Samples 75, $80 \mathrm{~m} \mathrm{MD)} \mathrm{to} \mathrm{multi-modal} \mathrm{profiles}$ $(60,65 \mathrm{~m} \mathrm{MD})$ is observed.

$6-$

\section{Grain-size profiles: $60-80 \mathrm{~m} \mathrm{MD}$}

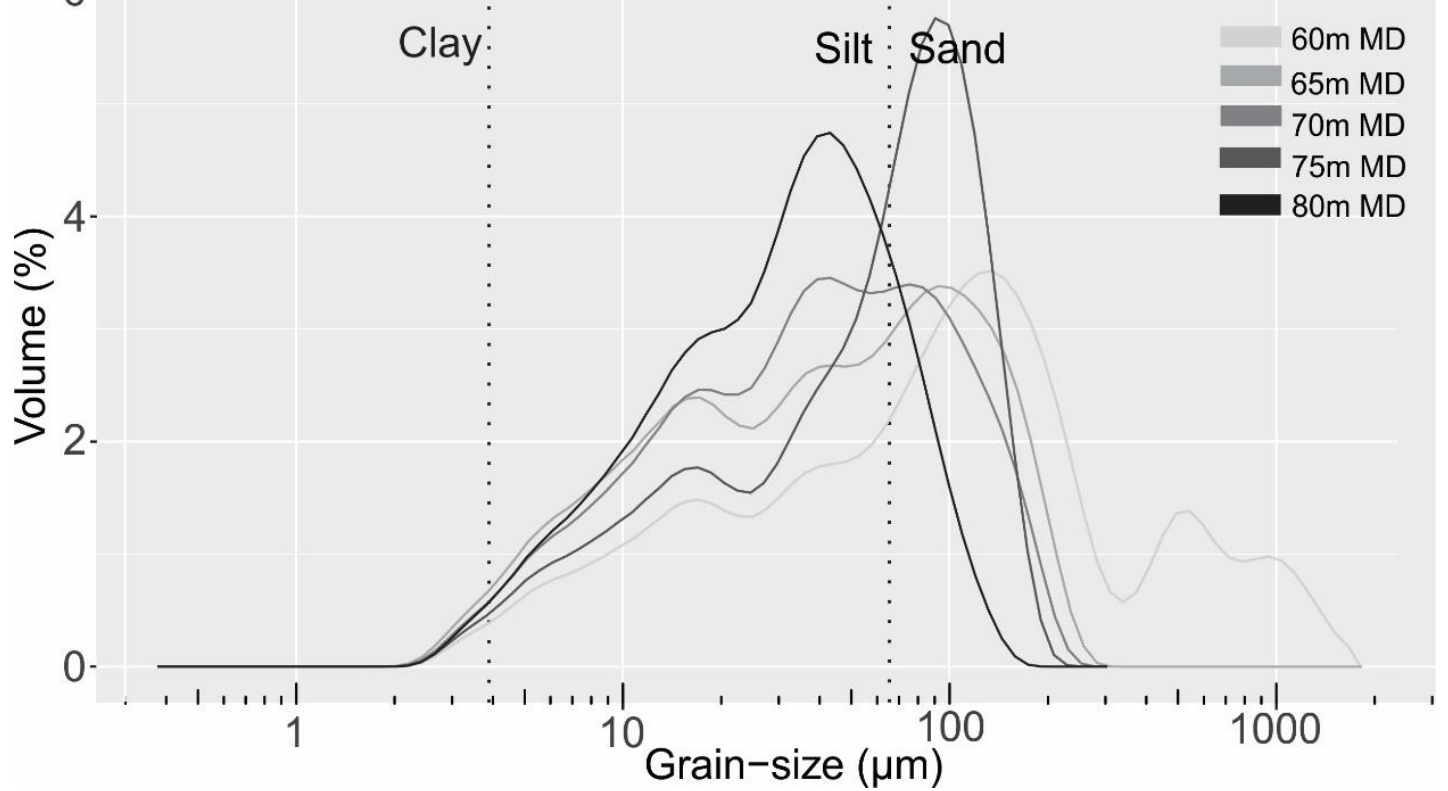

Figure 5.6 Grain-size profiles of samples from 60-80m MD. Full grain-size data available in Digital Appendix C.

\section{${ }^{14} \mathrm{C}$ chronology}

Several macro-organic samples were collected from the interval 59-80 metres MD, with two samples from 59 and 60 metres MD submitted for ${ }^{14} \mathrm{C}$ analysis. Samples returned the following modelled ages:

— DFDP 2A 59 metres MD: $15944 \pm 94$ cal. yr BP

— DFDP 2A 60 metres MD: $15970 \pm 102$ cal. yr BP

These dates show the uppermost section of the fine-medium sandstone unit to be deposited during the last glacial-interglacial transition (LGIT). This unit is $\sim 1$ kyr older 
than the maximum age interpreted for the upper gravels unit, requiring an unconformity to be present between units. Raw ${ }^{14} \mathrm{C}$ data is available in Appendix A1.

\subsubsection{Facies comparison}

Grain-size profiles from samples 70, 75 and 80 metres MD are comparable to bulk samples of facies Flr and Fl deposits from field site Waitan-9 (Section 3.1.3). Similarly, profiles from coarser grained samples (60,65 metres MD) are comparable to S1 and Slr deposits identified at the Cesspool field site.

The facies scheme and depositional model developed associates Sl and Slr deposits as formed at the toe/slope of a prograding delta. Fl and Flr facies are associated with density flow deposits deposited off the delta onto a low angle bed-slope.

\subsubsection{Interpretation}

The fine-medium sandstone unit is interpreted as deposited proximal to, or as part of a prograding lacustrine delta. Grain-size increases up section are interpreted to represent deposition in a progressively higher energy environment, associated with shallowing of the delta, and deposition of coarser-grained facies assemblages.

A lack of calcareous macro/micro fauna suggest the depositional environment to be lacustrine, rather than marine.

\subsection{Depth interval 80-206.1 metres MD}

Samples from depth interval 80-206.1 metres MD comprise cuttings and wet sediment samples recovered at 1-20 metre sampling intervals. Additionally, a 32-metre interval (125.5-157.3 metres MD) was cored from DFDP-2A, with variable 0-100\% core run recovery.

The gross lithology of the unit identified is a laminated-massive siltstone, interbedded with a $~ 2$-metre thick diamictite (Figure 5.7). The upper contact between the laminated siltstone unit and the overlying sandstone is gradational over $\sim 10$ metres, defined by a grain-size change from silt to very fine sand (Figure 5.8). 


\subsubsection{Core photographs}

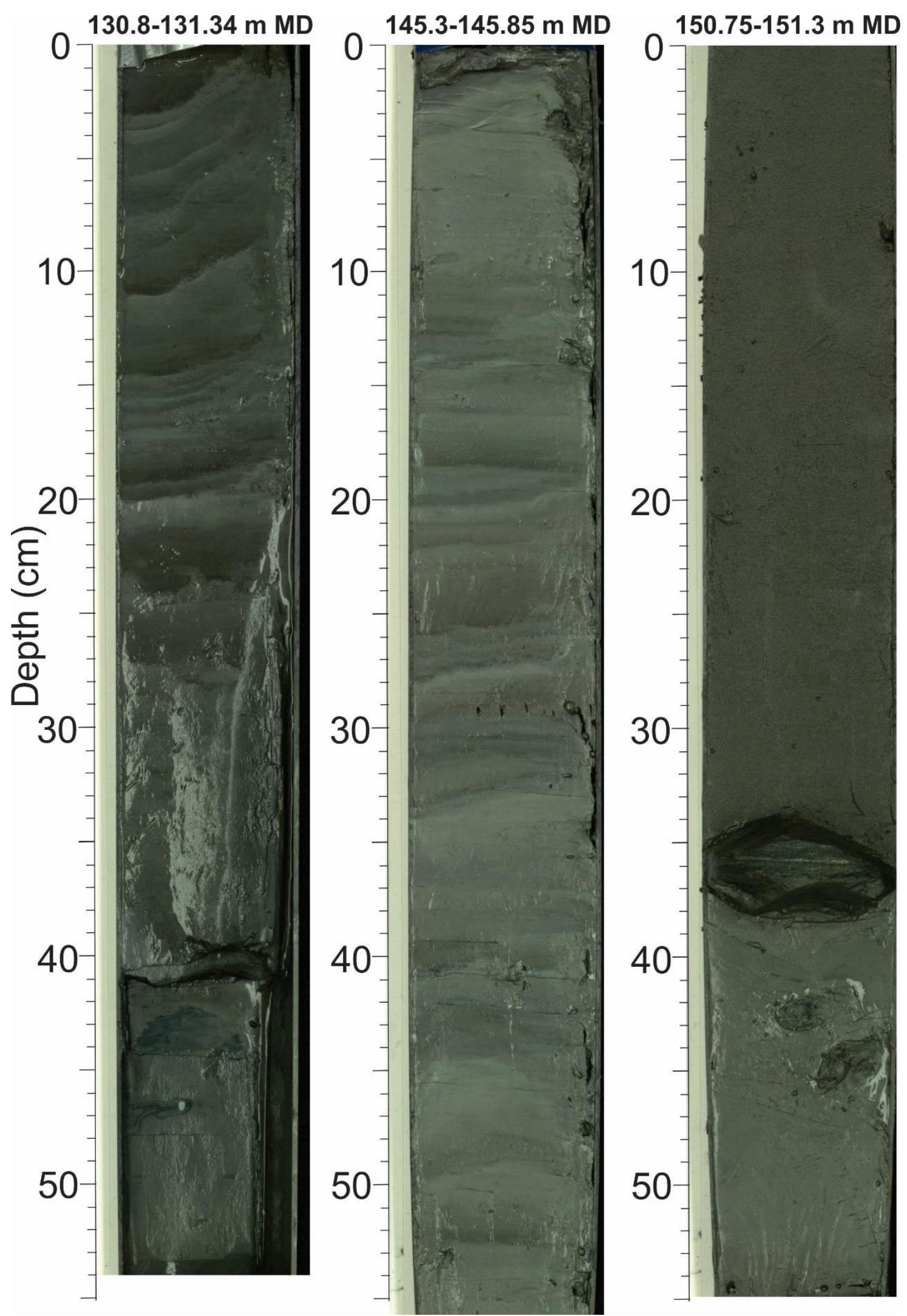

Figure 5.7 Photographs from key sections of sediment core, displaying variable bedding structure, grain-size and deformation structures. Left and centre images display laminated beds in the laminated siltstone unit, right image displays lower contact of diamictite bed, marked by the presence of a cobble clast overlain by a weakly graded sandstone. Full core images available in Appendix C. 


\subsubsection{Section log}

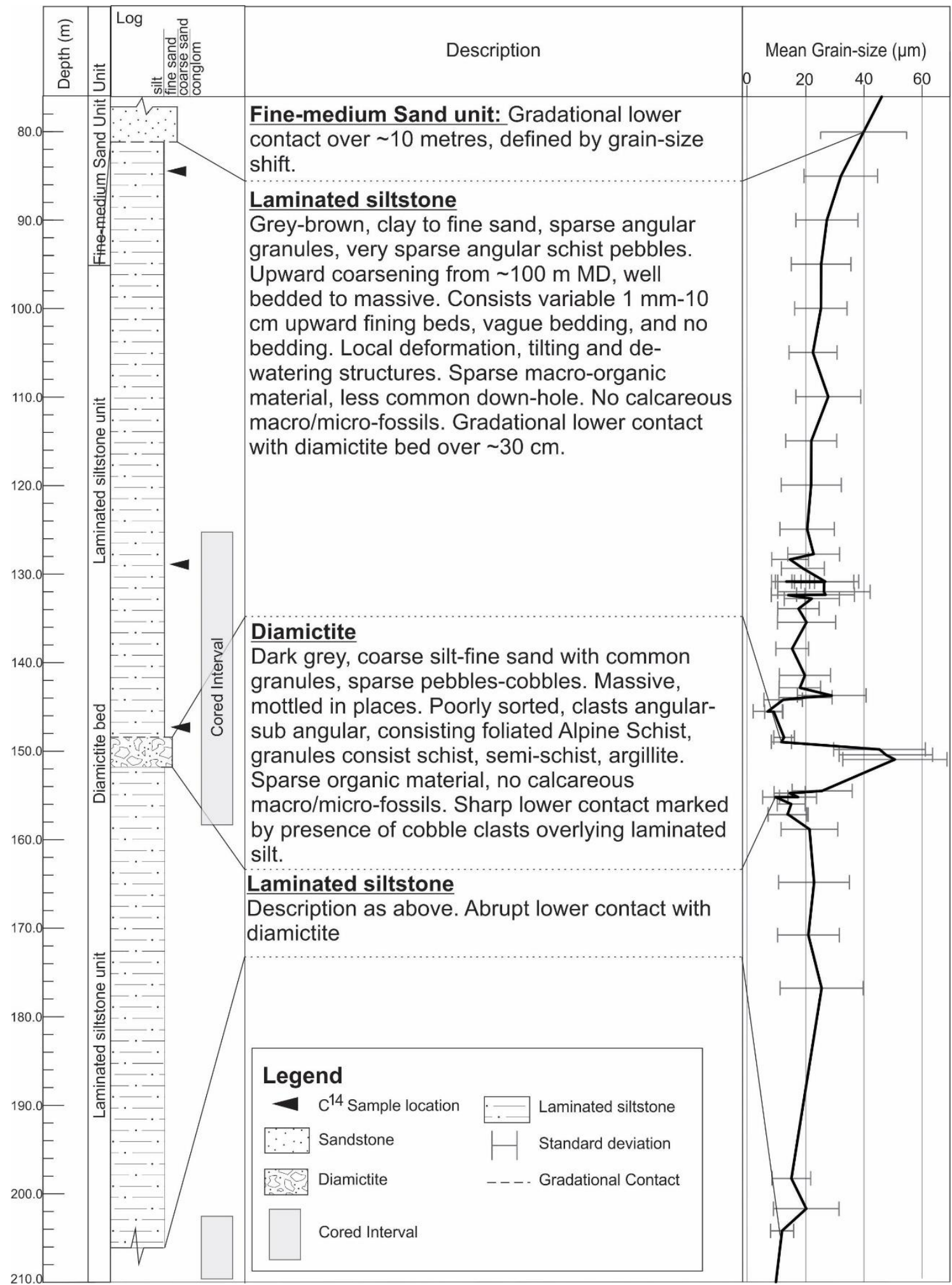

Figure 5.8 Section Log for interval 80-206 metres MD, with mean grain-size and standard deviation (bar range) plotted down-hole. Summary grain-size data available in Appendix A4. 


\subsubsection{Results}

\section{Grain-size analysis}

Mean grain-size trends through this section (Figure 5.8) display a progressive downward fining in grain-size, accompanied by a decrease in standard deviation to $\sim 100$ metres MD. From 100 metres MD, mean grain-size is observed to remain relatively constant at $\sim 20 \mu \mathrm{m}$ to the base of this unit, displaying silt-dominated bi-modal grain-size profiles (Figure 5.9). This suggests that processes dominating sediment flux broadly remained consistent through the deposition of the 100-206.1 metre MD interval. A significant deviation from the mean is observed in the diamictite bed at $~ 150 \mathrm{~m} \mathrm{MD}$, with grain-size returning to $\sim 20 \mu \mathrm{m}$ at the lower contact of the diamict. Clasts recovered from the diamictite bed range from pebble-large cobble, appearing more concentrated at the base of the unit.
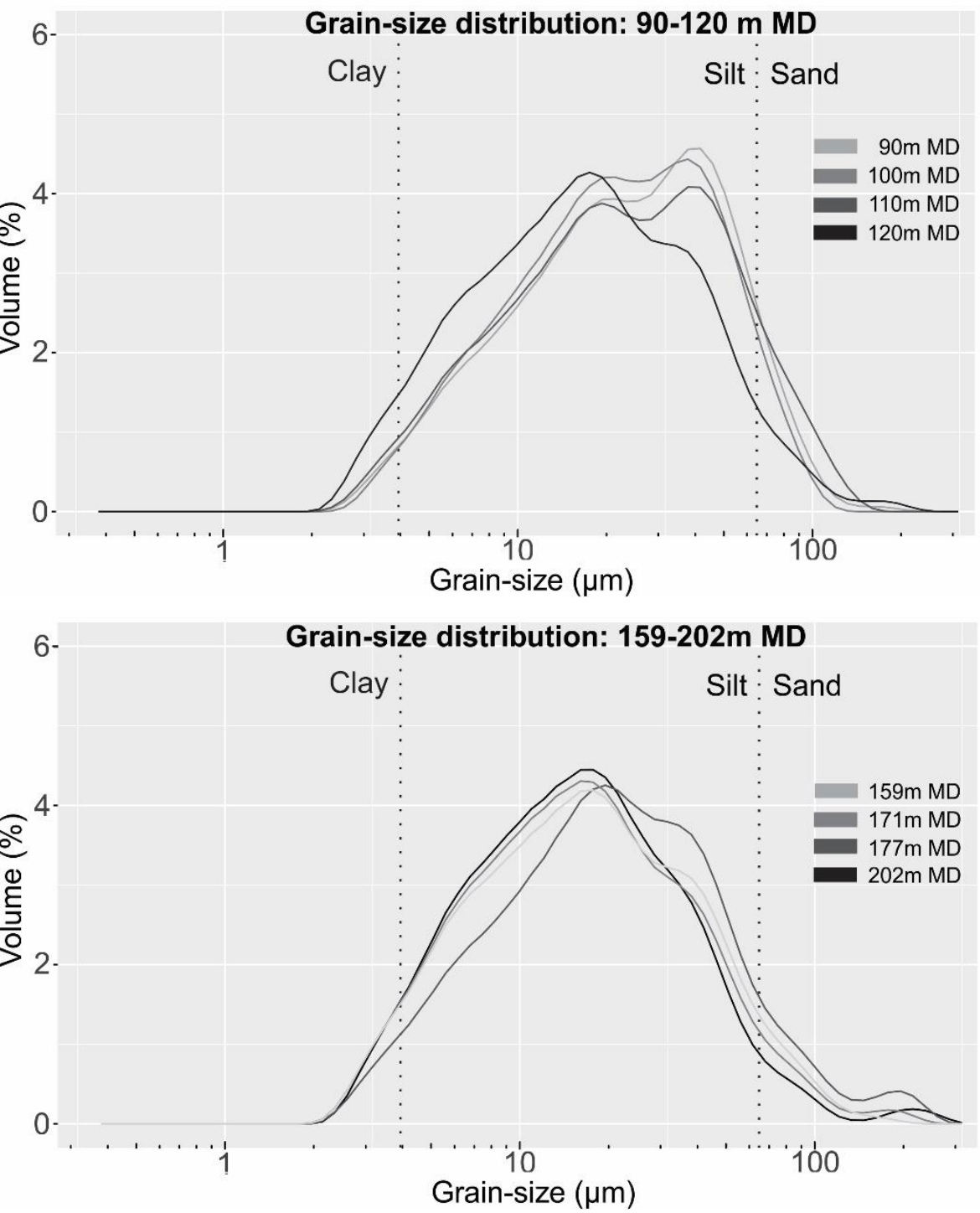

Figure 5.9 Grain-size distribution of cuttings samples taken above (top) and below (bottom) of main cored interval (126-159 metres MD). Full grain-size data available in Digital Appendix C. 
The cored interval (126-159 metres MD) allow trends in grain-size to be evaluated on a $\mathrm{mm}-\mathrm{cm}$ scale, displaying grain-size variance within single beds. This variability is displayed in Figure 5.10 and Figure 5.11.

Common cm-scale dark (coarser) to light (finer) coloured beds consistently fine upwards (Figure 5.10, top image), coupled with decreases in standard deviation. Sections of core consist of very fine silt-clay beds, with minor upward fining to a median grain-size of $\sim 3 \mu \mathrm{m}$ (Figure 5.10, bottom image). In the silt and sand units, finer grained beds are consistently lighter coloured.

The diamictite bed comprises a bi-modal fine sand matrix, with common pebble and a single large cobble clast defining the base of the unit (Figure 5.11). The matrix grainsize shows a slight upward fining in mean grain-size from $\sim 50$ to $\sim 45 \mu \mathrm{m}$ through the diamictite bed.

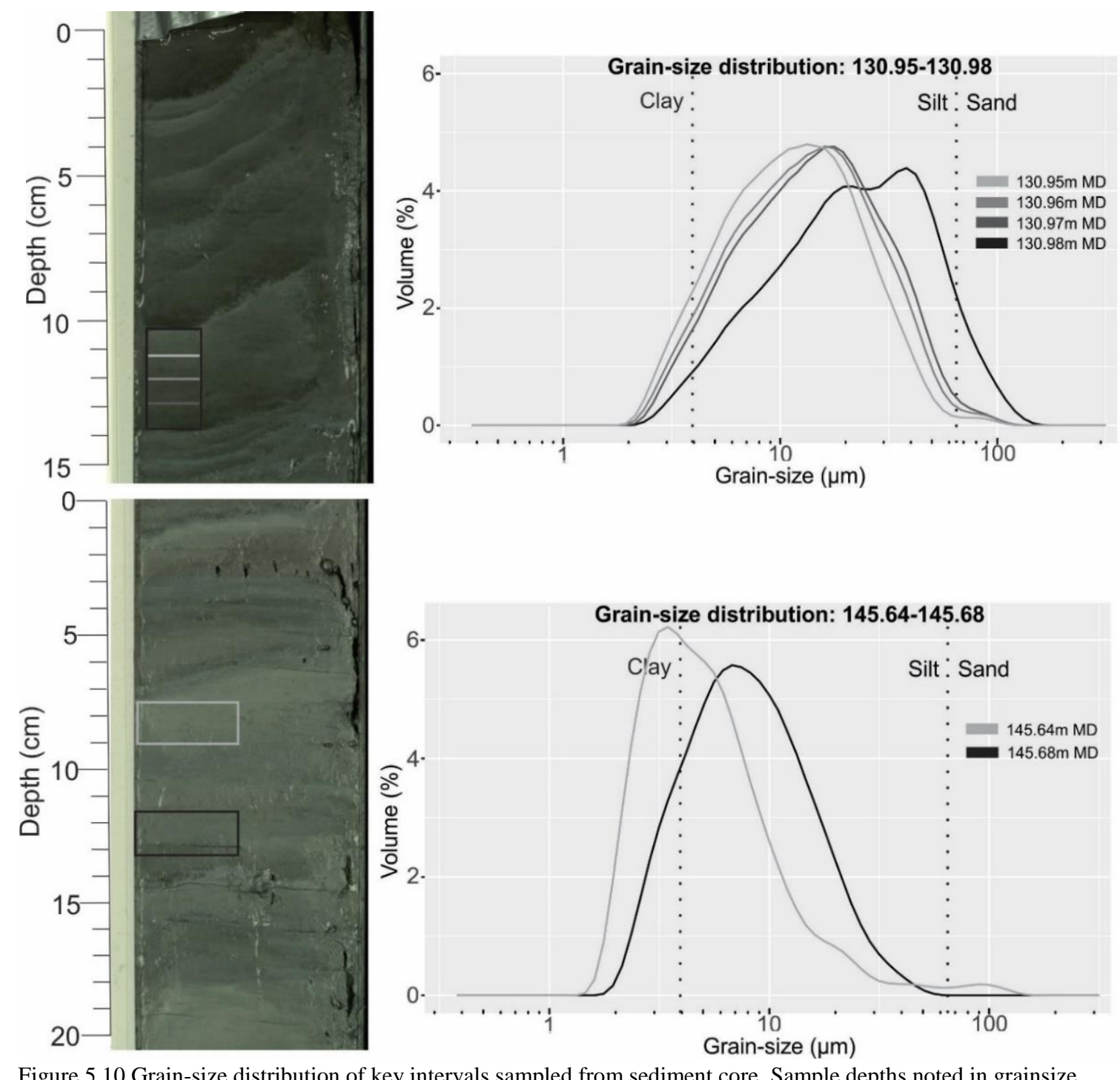

Figure 5.10 Grain-size distribution of key intervals sampled from sediment core. Sample depths noted in grainsize plots. Top image displays upward fining of $\sim 4 \mathrm{~cm}$ thick bed. Bottom image displays interval of complex upward fining beds with very fine grain-sizes. Full grain-size data available in Digital Appendix C. 


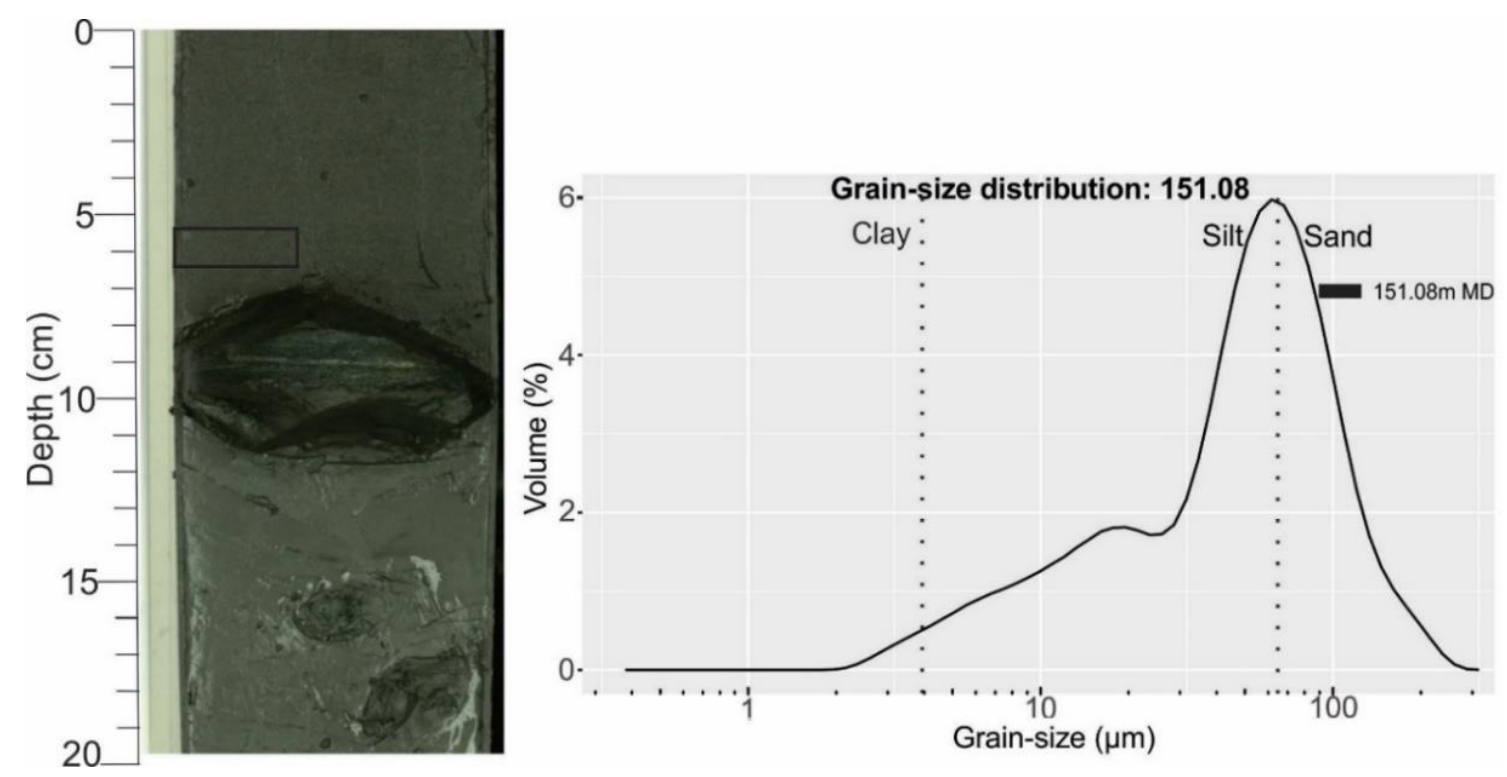

Figure 5.11 Matrix grain-size profile from the basal sample of the diamictite bed, $\sim 150$ metres MD. Sample depths noted in grainsize plots. Image shows large flat lying foliated schist cobble recovered in sediment core, marking the base of the diamictite bed. Full grain-size data available in Digital Appendix C.

\section{${ }^{14} \mathrm{C}$ chronology}

Macro-organic material was collected from depth interval 80-206.1 metres MD, with three samples submitted for ${ }^{14} \mathrm{C}$ analysis. Samples returned the following modelled ages:

- DFDP 2A 84.0 metres MD: 16,060 \pm 158 cal. yr BP

- DFDP 2A 129.3 metres MD: 16,225 \pm 120 cal. yr BP

— DFDP 2A 144.1 metres MD: 16,290 \pm 135 cal. yr BP

${ }^{14} \mathrm{C}$ ages show the interval 80-206.1 metres MD to be deposited during the LGIT, between $\sim 16,350$ and $\sim 15,950$ cal. yr BP. Mean sedimentation rates for the deposition of this 126-metre-thick unit are calculated at $\sim 31 \mathrm{~cm} / \mathrm{yr}$, though within errors rates could considerably slower, or more rapid than this.

\subsubsection{Facies identification and comparison}

Recurring beds are identified in the laminated siltstone unit through visual logging of the cored section, aided by grain-size analysis (Table 19, Figure 5.12, Figure 5.13).

Laminated, upward fining silt beds identified in cored intervals show comparable thickness, appearance and grain-size profiles as Fl facies identified in outcrop studies. Mottled silts also light to dark coloured, upward fining architecture, though beds have been deformed via soft sediment deformation or drilling related deformation.

The diamictite bed identified in a core section closely resembles Sm facies, interpreted as deposited via sub-aqueous flows as a debrite-turbidite type deposit. 
Very weakly upward fining to massive coarse and fine siltstone beds are prominent in the cored interval, with variable architecture and bed thickness. Grain-size analysis shows some upward fining occurring in $\sim 60 \%$ of beds assigned as massive coarse/fine silts (Table 19).

Massive fine to coarse silt deposits showing no upward fining are provisionally assigned as Fl, Flr or Sm facies which have undergone post depositional deformation. This deformation may be related to glacio-tectonic or tectonic events, soft sediment deformation, or drilling related deformation. Grading or laminations may be present in these deposits, though not evident in core photographs.

Table 19 Recurring beds identified from the cored interval of the laminated siltstone unit, with mean grain-size, and percent of total core length displayed. Facies scheme presented in Chapter 4 is utilised to determine facies equivalents.

\begin{tabular}{|ccccc|}
\hline Beds identified & Mean grain-size $(\mu \mathrm{m})$ & Length of core $(\mathrm{m})$ & Percent of total length & Facies Equivalent \\
Laminated silts & $\sim 10-30$ & 4.11 & 28.05 & $\mathrm{Fl}$ \\
Massive coarse silts & $\sim 25$ & 4.58 & 31.26 & $\mathrm{Fl} / \mathrm{Flr} / \mathrm{Sm}$ \\
Massive fine silts & $\sim 14$ & 3.5 & 23.89 & $\mathrm{Fl} / \mathrm{Flr} / \mathrm{Sm}$ \\
Diamictite & $\sim 55$ & 1.3 & 8.87 & $\mathrm{Sm}$ \\
Mottled silts & $\sim 20$ & 1.16 & 7.92 & $\mathrm{Fl}$ \\
\hline
\end{tabular}
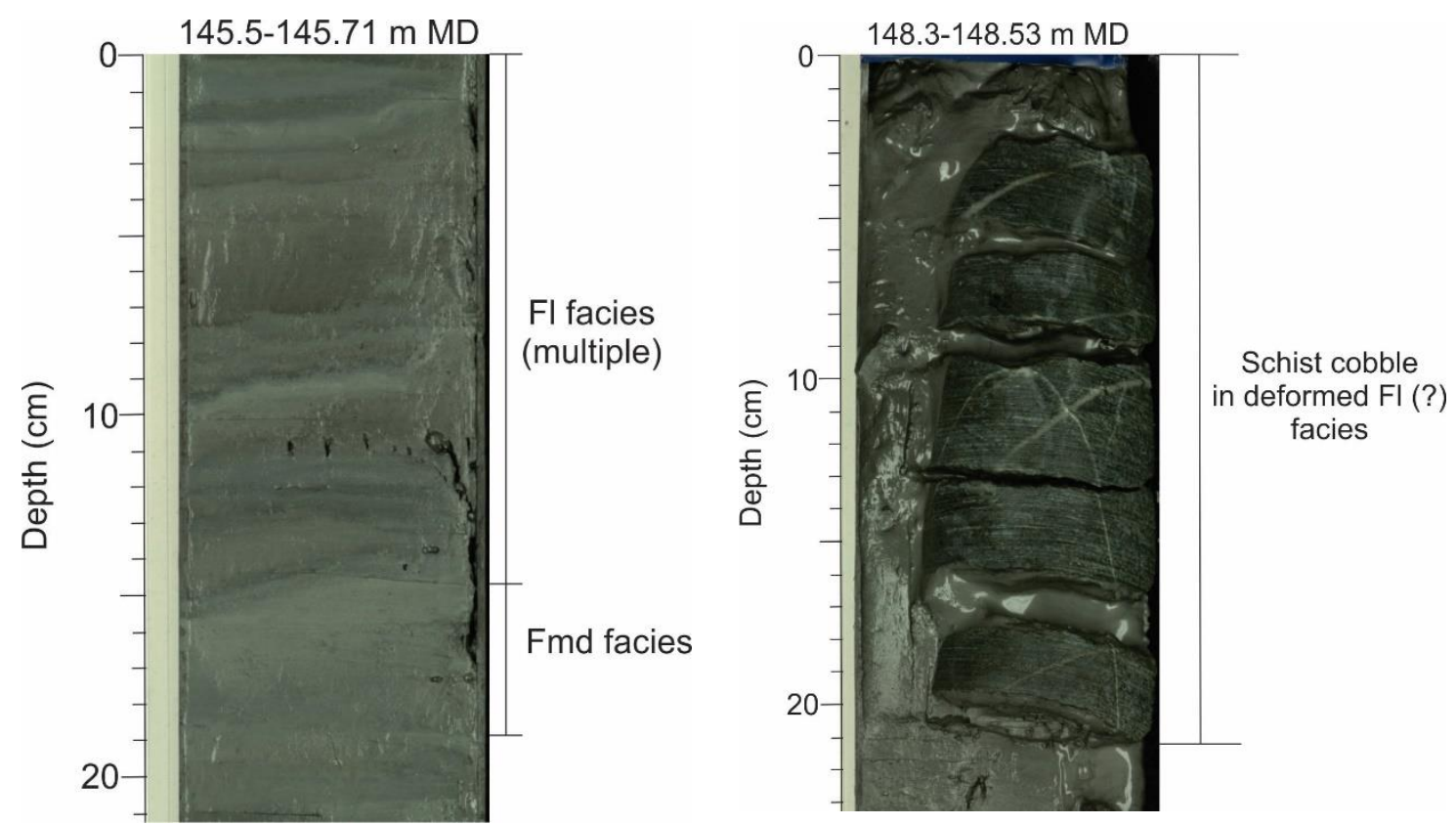

Figure 5.12 Annotated core photographs with key facies identified. Left image shows multiple $\mathrm{cm}$ scale upward fining beds identified as Fl facies, with poorly bedded clay-silt beds identified as Fmd facies. Right image shows large schist cobble interpreted as IRD (drilled on outer edge) hosted in fine silt matrix. Full core photographs available in Digital Appendix C. 

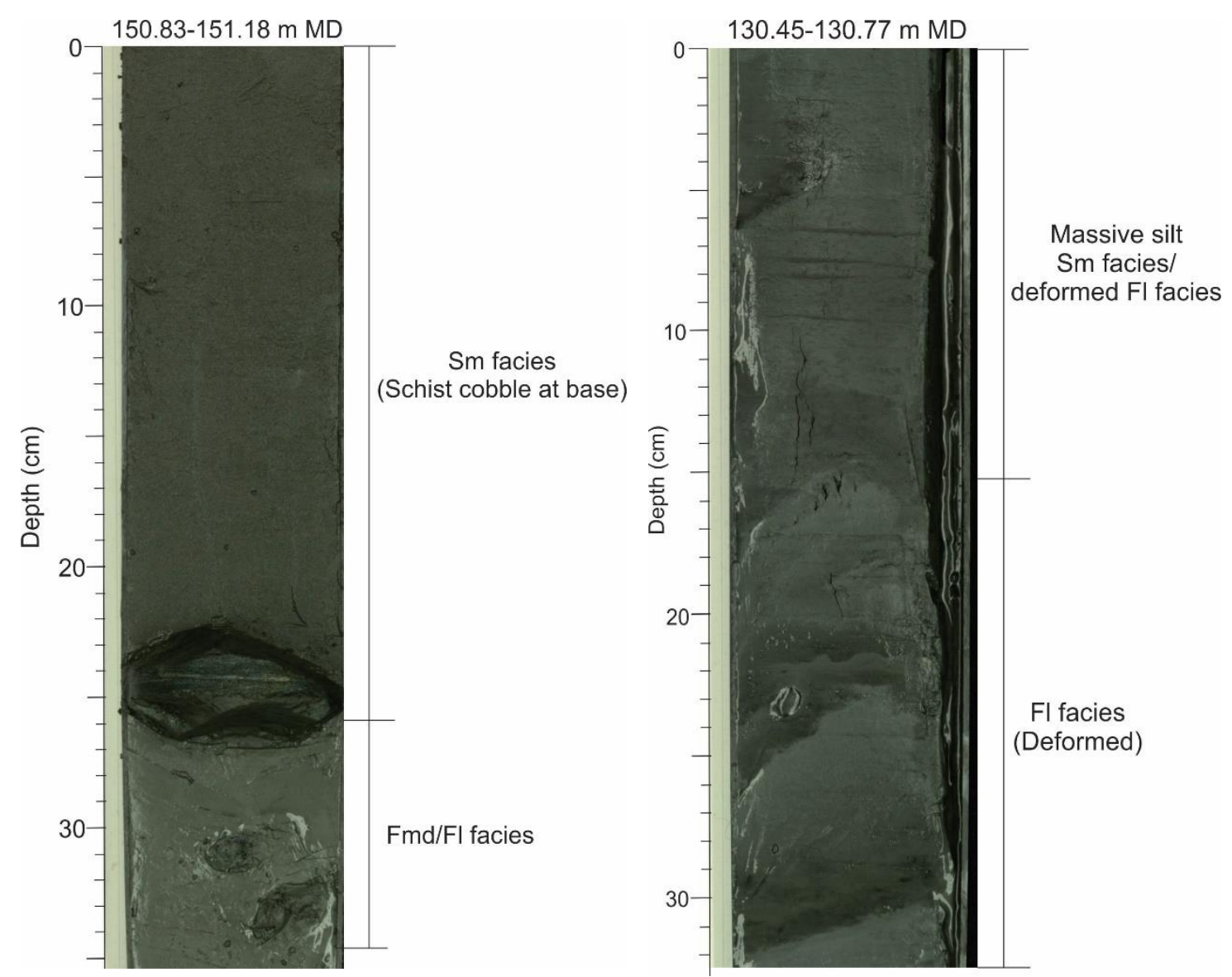

Figure 5.13 Annotated core photographs with key facies identified. Left image: very fine silt, overlain by the massive diamict bed identified as Sm facies. Right image: deformed 2-10 cm scale Fl facies, overlain by a massive fine silt bed interpreted as either a fine-grained Sm facies or deformed Fl facies.

\subsubsection{Interpretation}

Fine-grained, upward fining beds identified in sediment core closely resemble rhythmite deposits associated with lacustrine depositional environments. Common granule and pebble clasts, as well as sparse lonestone cobbles hosted in very fine sediments are interpreted as ice rafted debris, indicating ice terminating in the water body at the time of deposition. Absence of calcareous macro or micro-fauna implies the depositional environment to be lacustrine, opposed to marine.

Due to these factors, the interval $80-206.1$ metres MD is interpreted as deposited in an ice contact glacio-lacustrine depositional environment.

\subsection{Depth interval 206.1-240 metres MD}

Samples recovered from depth interval 206.1-240 metres MD consist a $\sim 1.5$ metre section of sediment core from DFDP-2A, and wet sediment samples from DFDP-2B. The gross lithology of the unit recovered is a diamictite with clasts ranging from pebble to boulder size, described further in Figure 5.14. The upper contact between this unit 
and the overlying laminated siltstone unit is inferred to be abrupt, signified by a rapid decrease in penetration rates during drilling.

This unit is observed to overlie the regional bedrock, with the unit acting as an aquifer for significant volumes of $\sim 40{ }^{\circ} \mathrm{C}$ fluid.

\subsubsection{Section log}

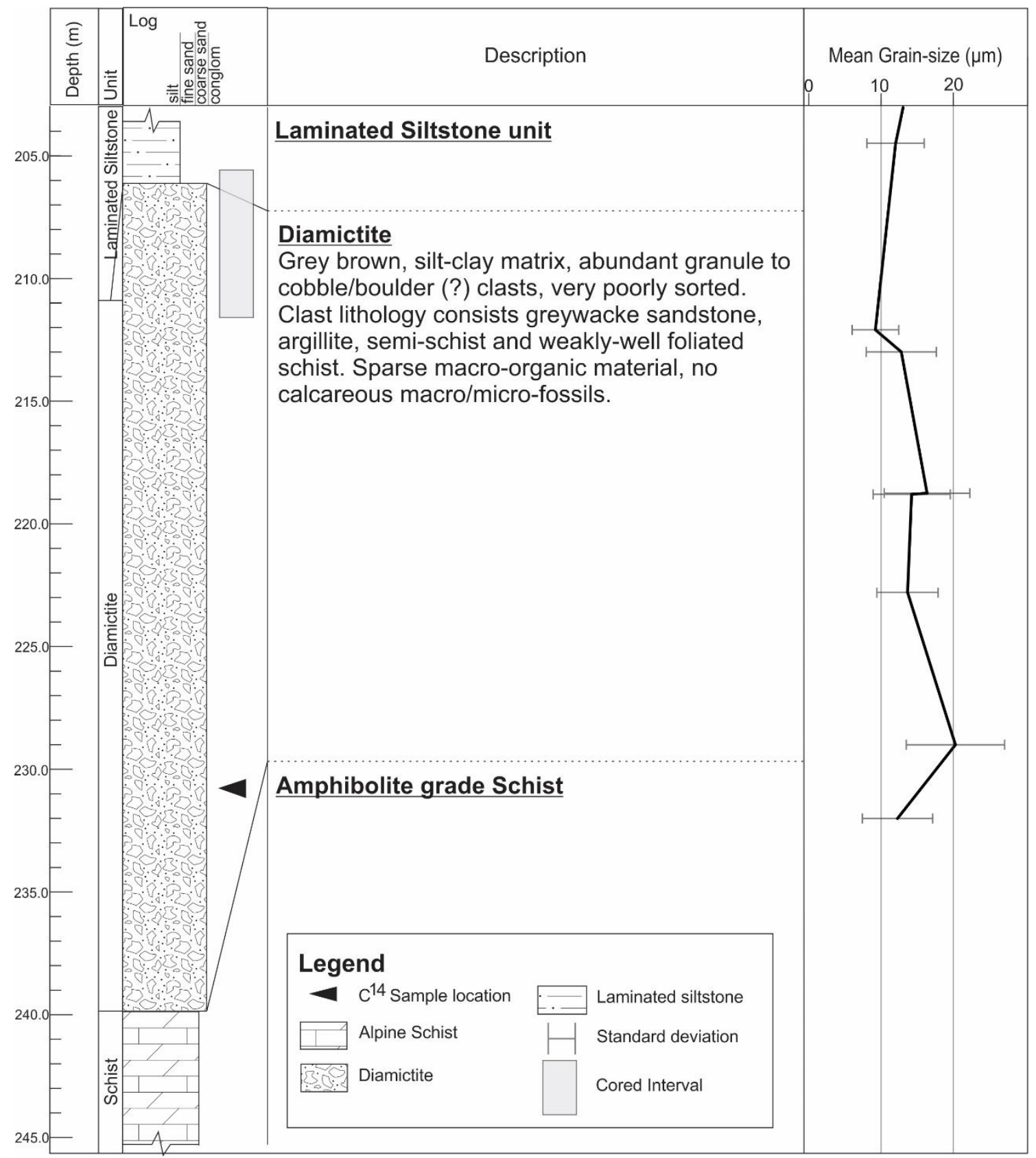

Figure 5.14 Section log for the diamictite unit at 206.1-240 metres MD, with mean matrix grain-size and standard deviation (bar range) shown. 


\subsubsection{Results}

\section{Grain-size analysis}

Though recovery was limited, the cored interval retrieved a pebble-cobble diamictite at 206.1-211 metres MD, appearing clast supported and lacking matrix. The matrix samples analysed for grain-size (Figure 5.15) are derived from cuttings samples returned during drilling, opposed to samples from coring. These samples also contained $\mathrm{mm}-\mathrm{cm}$ size rock cuttings fragments, derived from large clasts which were fractured during drilling.

The lack of matrix in core samples suggests either the fine-grained matrix was not retained during coring, that the unit itself is variably matrix and clast supported through the section, or that the matrix analysed was produced by rotary drilling.

Mean grain-size of the clay to silt-sized diamictite matrix is displayed in Figure 5.14, showing variations between $10-20 \mu \mathrm{m}$ through this unit. Grain-size distributions are observed to be consistently uni-modal (Figure 5.15), with no consistent upward fining or coarsening over the 33.9-metre interval.

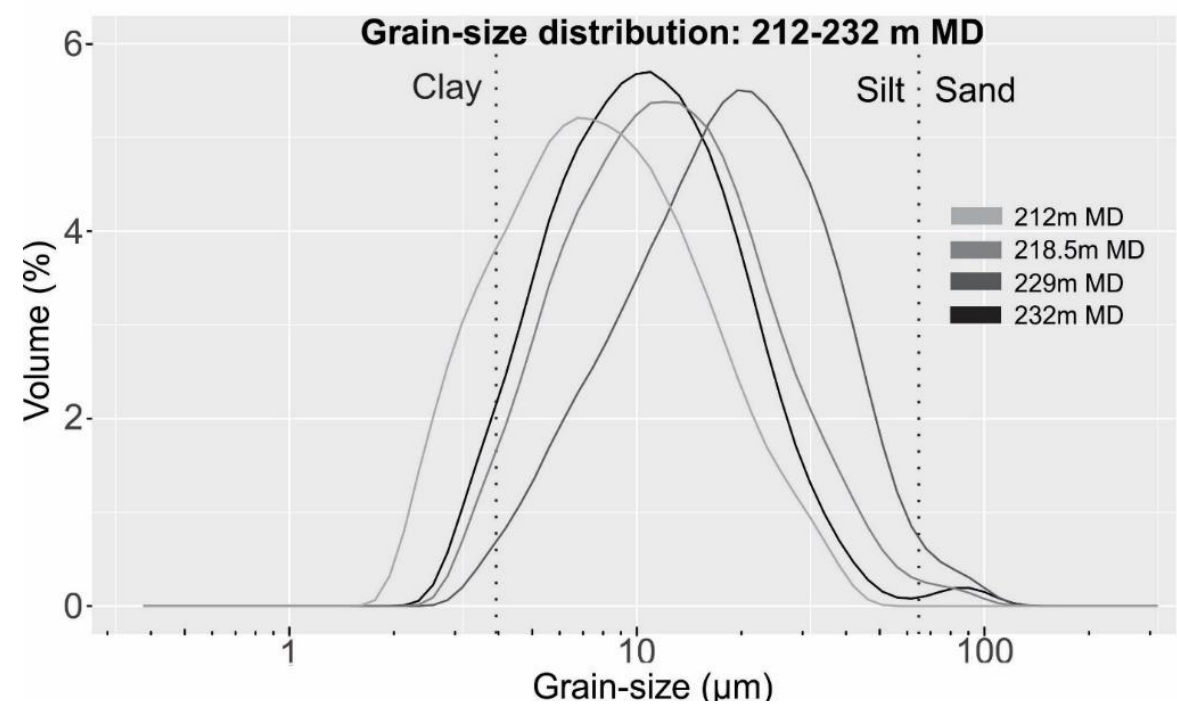

Figure 5.15 Grain-size profiles of clay-silt matrix from depth interval 206.1-240 metres MD. Full grain-size datasets are available in Digital Appendix C.

\section{Clast lithology}

Of the 21 pebble-cobble clasts recovered in the cored interval, 11 consisted biotitegarnet zone schist, 5 consisted greenschist facies semi-schist, and 4 consisted prehnitepumpellyite grade sandstone. A single proto-mylonite clast was also recovered. Samples 
are therefore derived from multiple locations in the Whataroa catchment, opposed to a single point source in the catchment.

\section{${ }^{14} \mathrm{C}$ chronology}

A single sample of macro-organic material was submitted for ${ }^{14} \mathrm{C}$ analysis. This sample returned the following modelled age:

— DFDP 2B 230.5 metres MD: $16609 \pm 151$ cal. yr BP

The diamictite unit was deposited during the LGIT period, comparable to the overlying laminated siltstone unit

\subsubsection{Facies identification}

No appropriate outcrop equivalents for the diamictite unit were analysed in this study, therefore analogues from published research are utilised. Massive, pebble-boulder units identified in the cored interval are interpreted as Gs facies, formed by subglacial release and rainout. Cuttings samples retrieving fine-grained clays and silts, as well as coarse chip fragments from clasts are interpreted as either Gs or Gms facies.

Gg type facies, deposited by re-sedimentation of diamict material may also be present in the diamictite unit, though cannot be distinguished from Gs or Gms facies in cuttings samples.

\subsubsection{Interpretation}

The presence of pebble-cobble clasts, along with fine silt and clay particles in the diamictite unit indicates deposition of the diamictite unit occurred with minimal sorting or reworking, characteristic of glacial diamictites. Clast lithology shows clasts to be derived from throughout the Whataroa catchment, as opposed to a single point source. Deposition of this unit by mass movement processes such as land sliding of a debuttressed hillslope is unlikely, as clasts from a point source would be expected to be of a single lithology.

The pebble to boulder diamictite intercepted from 206.1-240 metres MD is interpreted as a glacial diamict, deposited proximal to the grounding line of a receding glacier. This interpretation is based upon the characteristics of the unit outlined above, as well as its age and stratigraphic position. This is discussed further in section 5.5.2. 


\subsection{DFDP-2: Full sedimentary sequence}

This section presents the section log for the full sedimentary sequence recovered by DFDP-2 (Figure 5.16), as well as the age model for the lower $\sim 170$ metres of the sequence.

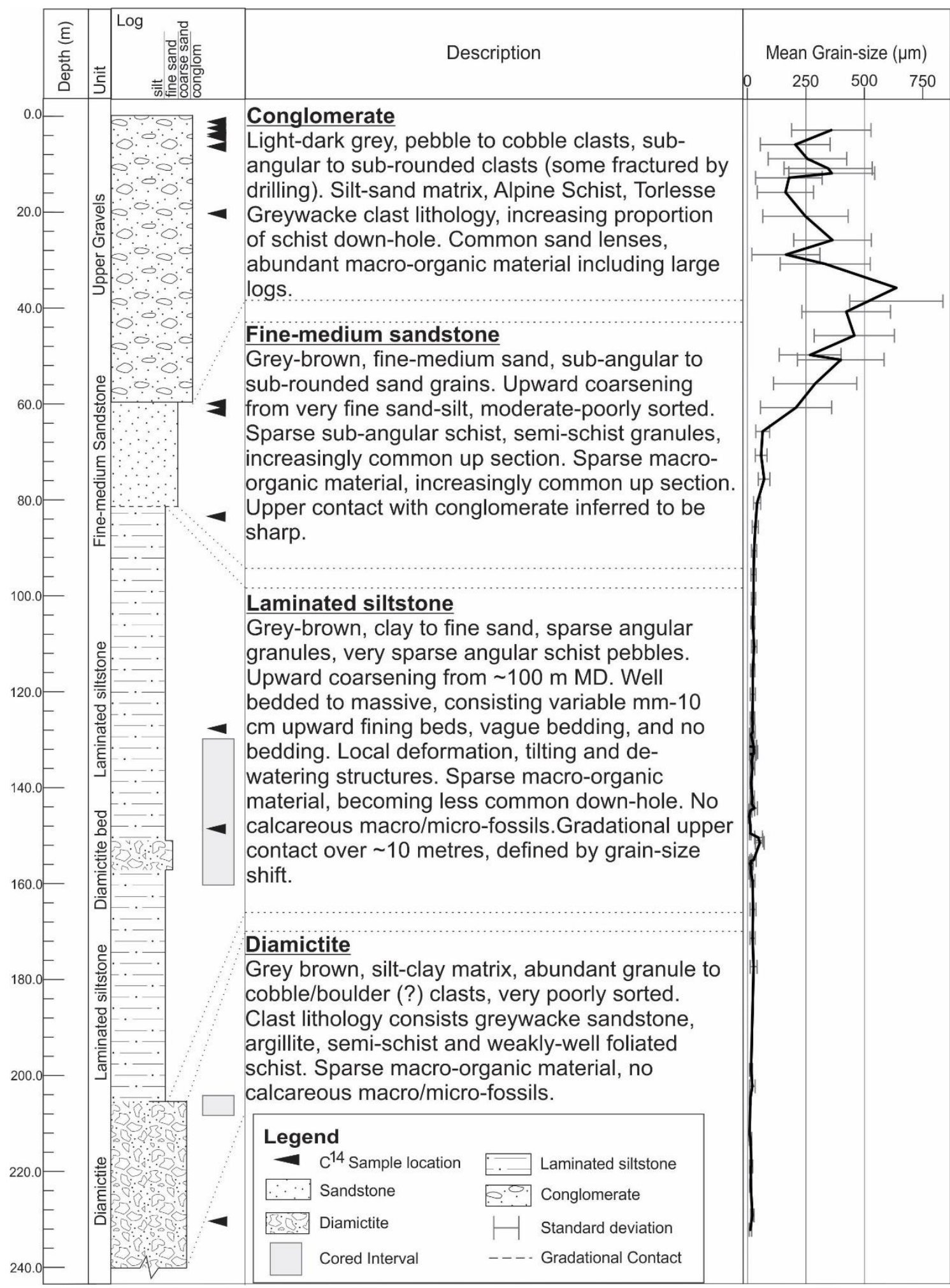

Figure 5.16 Full section log for 0-240 metres MD, with mean matrix grain-size and standard deviation (bar range) plotted. Summary grain-size data is available in Appendix A4. Diamictite bed description in Figure 5.8. 


\subsubsection{Age model: 59-230.5 metres MD}

Radiocarbon age model parameters are presented in Section 2.5, with the model output presented in Figure 5.17.

The age model shows the 230.5-59 metres MD interval accumulated between $16609 \pm$ 151 and $15994 \pm 94$ cal. yr BP, indicating 171.5-metre thick interval accumulated in $659 \pm 151 \mathrm{yrs}$. Assuming a linear sedimentation rate through this period, age and depth limits constrain the deposition rate to between 20.66 and $33.38 \mathrm{~cm} / \mathrm{yr}$. This exceptionally high deposition rate indicates extremely rapid sediment accumulation occurring at the drill-site.

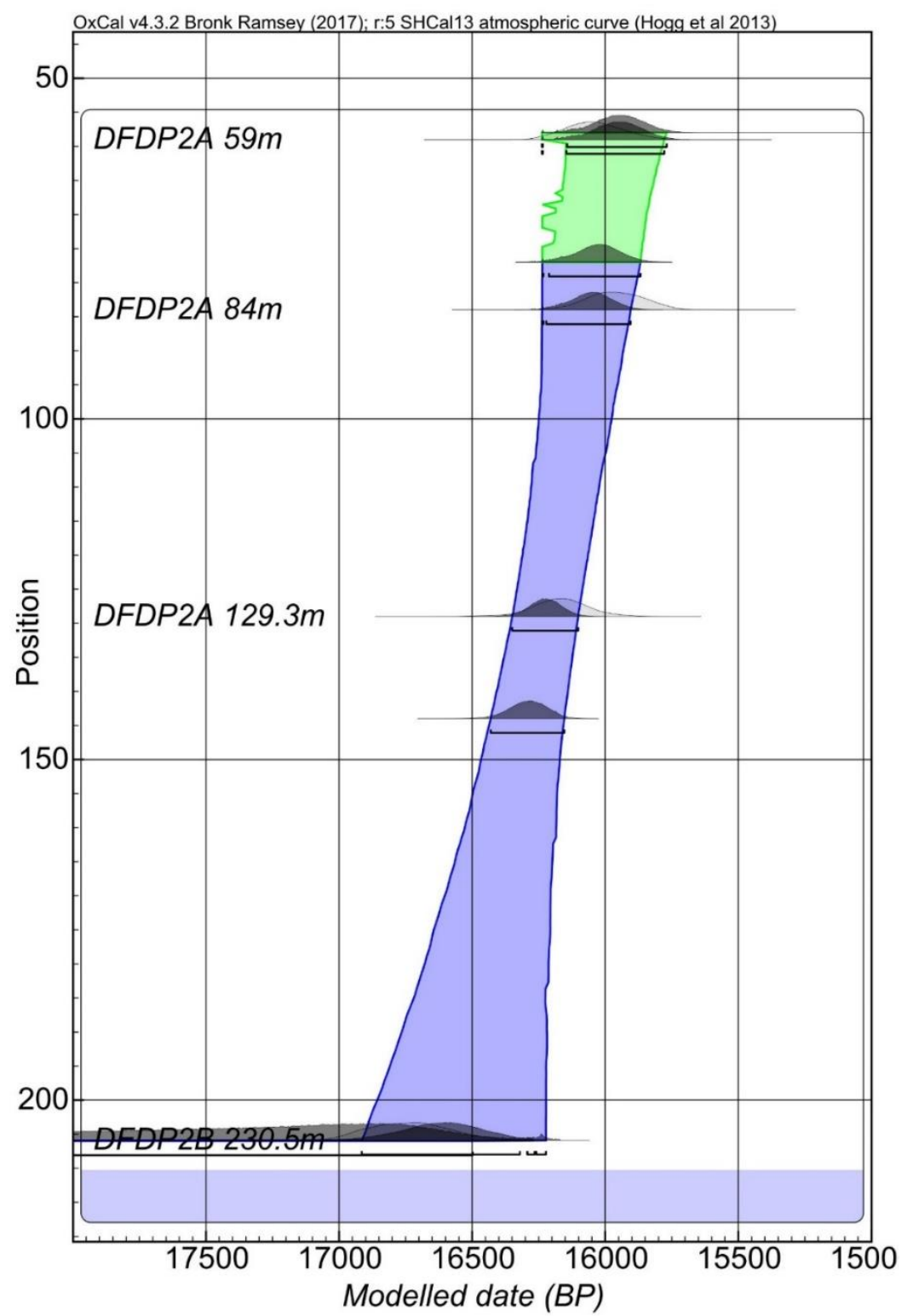

Figure $5.17{ }^{14} \mathrm{C}$ age model developed for DFDP-2, 59-230.5 metres MD. Raw ${ }^{14} \mathrm{C}$ data is available in Appendix A1. 


\subsubsection{Integrated sequence interpretation}

The depth interval 240 to 59 metres MD intercepted by the DFDP-2 boreholes (Figure 5.16) consists a coarse boulder diamictite, overlain by a significant thickness of laminated and massive siltstone with rare diamictite, transitioning upwards to a finemedium sandstone. This sequence was most likely deposited in a pro-glacial lake that formed as a piedmont glacier retreated across an over-deepened glacial trough. The justification for this interpretation is outlined below, and discussed further in Chapter 6.

At $\sim 18-19 \mathrm{ka}$, the Whataroa glacier began retreating from the M6 glacial maxima on the Westland piedmont, and was upstream of the DFDP-2 drill-site by $\sim 14 \mathrm{kyr}$ at the onset of the ACR (Suggate and Almond, 2005, Newnham et al., 2012, Barrell et al., 2013). Between $\sim 18$ and $\sim 14 \mathrm{ka}$, the glacier must have receded back over the drill-site, depositing a basal diamict. The ${ }^{14} \mathrm{C}$ chronology for the diamictite unit at $\sim 16,650$ cal. yr BP places its deposition within this age range, supporting the inference that the diamictite unit represents a basal till.

The diamictite unit is overlain by the laminated siltstone unit, which displays rhythmite type laminations and contains common lonestones, which are characteristic of ice contact glacio-lacustrine deposition. A transition from glacial diamict to laminated siltstone is conformable. Deposition of laminated siltstone then persisted for $~ 200-400$ years.

A decrease in the abundance of lonestones at approximately 130 metres MD suggests that the depositional environment had evolved from an ice contact to an ice distal setting, with the ice margin beginning to terminate upstream of the lake margin. This transition is associated with a minor change in facies assemblages distal from the icefront, and significant changes in assemblages proximal to the ice front (Figure 4.1, Figure 4.2).

The depth estimate at which this transition occurs is considered approximate however, due to samples being recovered as drill-cuttings from 0-126 metres MD, meaning that lonestone clasts may have been fragmented by drilling in this interval.

In the interval above $\sim 130$ metres MD, high sediment accumulation rates likely caused progressive shallowing at the drill-site, as pro-glacial lake basin filled and a lacustrine delta began to prograde. These processes are reflected by facies changes through the 59- 
90 metres MD interval, with progressive coarsening upwards in grain-size and the deposition of the fine-medium sandstone unit.

The glacio-lacustrine interval of the DFDP-2 sedimentary sequence (240-59 metres $\mathrm{MD}$ ) is then overlain by aggradational fluvial deposits of the upper gravels unit, inferred to be $\sim 10-15 \mathrm{ka}$ at the base of the sequence. This facies shift reflects development of a fluvial plain at the drill-site, as aggradational fluvial deposits unconformably overtop the lacustrine delta deposits of the fine-medium sandstone unit. 


\section{Chapter 6 Discussion}

This chapter presents a discussion of results and interpretations developed in Chapters 3 through 5. Field sites in the Arahura and Waitangitaona rivers are discussed, with reference to the implications of outcropping lithological units for the geomorphic development of the catchments

The DFDP-2 sedimentary sequence is then discussed in detail, with reference to glaciolacustrine sedimentation and the development of a pro-glacial lake in the Whataroa region. Next, pro-glacial lake geometry and temporal development is discussed, utilising results of this study alongside published research to understand landscape response to glacial retreat in the Whataroa region.

\subsection{Arahura River sections}

Exposures of lacustrine sedimentary sequences at the Cesspool and Arahura Bridge sections were deposited when the valley contained a lake. Previously unmapped conglomerate and sandy siltstone units represent lacustrine delta toe and slope facies, based on facies identification and comparison with published analogues.

Both the conglomerate and sandy siltstone units are located upstream of latest Otiran moraine limits for the Arahura River. No sedimentary units older than late Otiran are documented within the LGM moraine limits for the Arahura valley, with glacially sculpted bedrock mapped downstream of the Arahura Bridge section (Barrell et al., 2013).

It is likely that the conglomerate and sandy siltstone units would have been eroded during latest Otiran ice advance, therefore the units are inferred to post-date the latest Otiran. Stratigraphic constraints from the Cesspool section show the sandy siltstone unit to be slightly younger than the conglomerate unit. 


\subsubsection{Defining possible lake extent}

For a paleo-lake to have formed in the Arahura river valley, a landscape feature acting as a lake dam must have existed. The most obvious feature downstream of the Arahura range-front is a late Otiran terminal moraine at Milltown, which presently causes significant deviations in the flow of the Arahura River. A terminal moraine dammed lake with an anthropogenic control structure occurs at Lake Kaniere, 8 kilometres westwards of the Arahura range-front, with a comparable piedmont geometry to the Arahura River, and offers an analogue to the Arahura paleo-lake.

Inferred lake geometry, relative to outcrops at the Arahura Bridge and Cesspool sections is presented in Figure 6.1. Exposures of the conglomerate unit at the Arahura Bridge section are measured at $~ 140$ metres AMSL (above present mean sea level). As the unit was deposited on the lake bed, below the lake water level, a minimum lake level of 160 metres is inferred, and a 160 metre AMSL contour utilised to map paleo-lake extent in Figure 6.1. Elevation data of the terminal moraine at Milltown constrains maximum lake water level to 200 meters AMSL.

Clasts present in the conglomerate and sandy siltstone unit do not exhibit remnant glacial form or striae. This observation implies that the Arahura glacier was upstream of the lake edge at the time this unit was deposited, and that clasts were reworked along a fluvial plain before being deposited into the paleo-lake. The exact position of the glacier margin cannot be constrained, and is not included in Figure 6.1. 


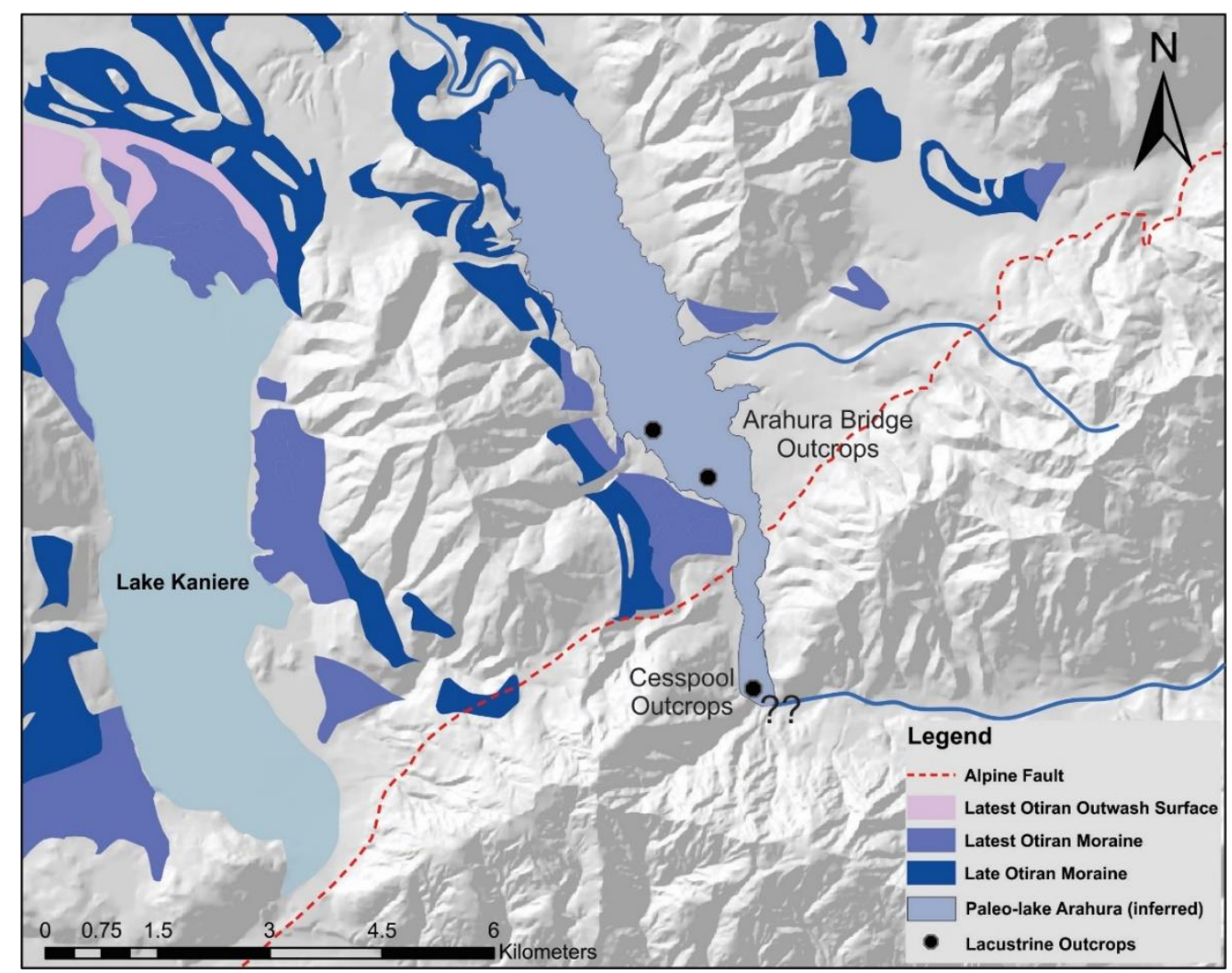

Figure 6.1 Inferred extent of paleo-lake Arahura, dammed by late Otiran moraine at Milltown. Downstream of the Alpine Fault, lake surface mapped using a 160 metre AMSL contour. Upstream of the Alpine Fault, lake extent mapped to the Cesspool outcrops. Outcrops of the lacustrine units at the Arahura Bridge and Cesspool sites marked in black. Alpine Fault trace mapped by Nathan et al. (2002), Moraine/outwash surfaces mapped by Barrell et al. (2013). Location of Arahura valley in Westland shown in Figure 1.3.

\subsubsection{Stratigraphic position and unit elevation}

The conglomerate unit described at the Arahura Bridge section stratigraphically overlies the sandy siltstone unit in outcrop exposures at the Cesspool section. At the Cesspool section, the contact between the conglomerate unit and the underlying sandy siltstone unit is measured at $202.4 \pm 0.3$ metres AMSL.

At the Arahura Bridge section the lower contact between the conglomerate unit and the underlying unit is not observed. The elevation of the conglomerate unit is measured at the base of the visible outcrop, though this point sits stratigraphically higher than the unit contact measured at the Cesspool section. The elevation measured for the conglomerate unit at the Arahura Bridge section is $140.45 \pm 0.3$ metres AMSL. The elevation difference of the conglomerate at the two sites is calculated as a minimum of 61 metres. The Alpine Fault is mapped between the Arahura Bridge and Cesspool sections, being on the footwall and hanging wall respectively. The potential for unit elevation differences to have been caused by post depositional uplift along the Alpine Fault is explored below. 
The conglomerate unit is interpreted to have been deposited between 18-12 ka. Prior to $\sim 18 \mathrm{ka}$, the Arahura glacier was likely proximal to the Cesspool section, influencing the depositional environment and clast shape, which is not observed in the analysis of this unit. Following $\sim 12 \mathrm{ka}$, it is unlikely that a remnant glacial trough downstream of the Arahura catchment would have persisted. The younger age limit for this deposit is more difficult to constrain than the older limit however.

Using age constraints from the stratigraphic units described herein, along with Alpine Fault uplift rates from nearby sites, the amount of uplift between 18 and $12 \mathrm{ka}$ is calculated. Twelve kilometres southwest of the Arahura River (Toaroha River), vertically offset terraces constrain dip-slip rates on the Alpine Fault to $7.8^{-3} \pm 1^{-3} \mathrm{~m} / \mathrm{yr}$ (Norris and Cooper, 2001). Twenty five kilometres northwest of the Arahura River (Inchbonnie), displaced alluvial surfaces yield significantly lower dip-slip rates of $3.4^{-3}$ $\pm 0.6^{-3} \mathrm{~m} / \mathrm{yr}$, corresponding to $2.9^{-3} \pm 0.4^{-3} \mathrm{~m} / \mathrm{yr}$ of vertical motion (Langridge et al., 2010). These rates are considerably lower than previous estimates of dip-slip rates of $6^{-3}$ $\pm{ }^{2-3} \mathrm{~m} / \mathrm{yr}$ at Inchbonnie (Norris and Cooper, 2001). The Arahura River sits between the two sites, with dip-slip rates decreasing from $\sim 8^{-3}$ to $\sim 3.5^{-3} \mathrm{~m} / \mathrm{yr}$ northwards as Alpine Fault motion begins to be taken up by the southern extent of the Marlborough Fault System (Langridge et al., 2010). A median value of $5^{-3} \pm 1^{-3} \mathrm{~m} / \mathrm{yr}$ is assumed for rates of vertical motion at the Arahura River.

Vertical offset of the conglomerate unit at the Cesspool section is calculated to be between $60 \pm 12$ metres (12 ka) and $90 \pm 12$ metres (18 ka).

\subsubsection{Additional uncertainties}

The vertical offset of the conglomerate between the Arahura Bridge section and Cesspool section cannot be attributed solely to vertical motion on the Alpine Fault due to three main unknowns:

- Depth of the sandy siltstone/conglomerate contact at the Arahura Bridge Site. As only the conglomerate unit is exposed, the unit elevation measured at the Arahura Bridge Site is stratigraphically higher than at the Cesspool section.

- The top of the conglomerate unit is not observed at either site, being unconformably overlain by horizontally bedded pebble-boulder conglomerate at both sites. The true thickness of the conglomerate unit, as well as the potential for spatial changes in thickness, is unknown.

- Expected dip/gradient of the sandy siltstone/conglomerate unit contact. Representing a shift from delta toe to delta slope facies deposited on the lake 
bed, this shift in environment may not have occurred at the same lake depth downstream.

The first two uncertainties will cause the total measured vertical offset to be underrepresented. The third uncertainty may lead to the measured vertical offset either under or over-representing the true vertical offset. This is dependent on the relative water depth in which the transition between delta toe and delta slope deposition occurred at the Cesspool and Arahura Bridge section. Constraining any depositional change in the elevation of the sandy siltstone-conglomerate contact was not attempted in this study. If ${ }^{14} \mathrm{C}$ chronology could be obtained for either units, the potential for the vertical unit offset to be attributed to Alpine Fault uplift could be better evaluated.

\subsection{Waitangitaona River sections}

Published research does not document or suggest a pro-glacial lake formed in the Waitangitaona River region. Despite this, the presence of the laminated siltstone outcrops documented here as the Waitangitaona lower and upper sections show that at least one generation of pro-glacial lake has formed in the Waitangitaona region.

\subsubsection{Pro-glacial lake chronology and extent}

Due to the spatial relationship between the lower Waitangitaona section outcrops and the latest Otiran outwash surface mapped by Barrell et al. (2013), the laminated siltstone unit identified here is inferred as latest Otiran in age. This inference is supported by the location of the outcrops within latest Otiran moraine limits for the Waitangitaona and Whataroa catchments. If the unit were older than latest Otiran, it should stratigraphically underlie latest Otiran moraines in the Waitangitaona region. Though a thin diamictite overlies the laminated siltstone unit at the Waitan-6 site, this unit was laterally discontinuous over $\sim 10$ metres and located inside moraine limits mapped by Barrell et al. (2013).

The close proximity of outcrop exposures in the lower Waitangitaona section limits their use to define the full lake extent. Lake boundaries are therefore defined using the spatial extent of late-latest Otiran moraine limits, as well as exposed hills of Western Province basement rocks (Figure 6.2). 


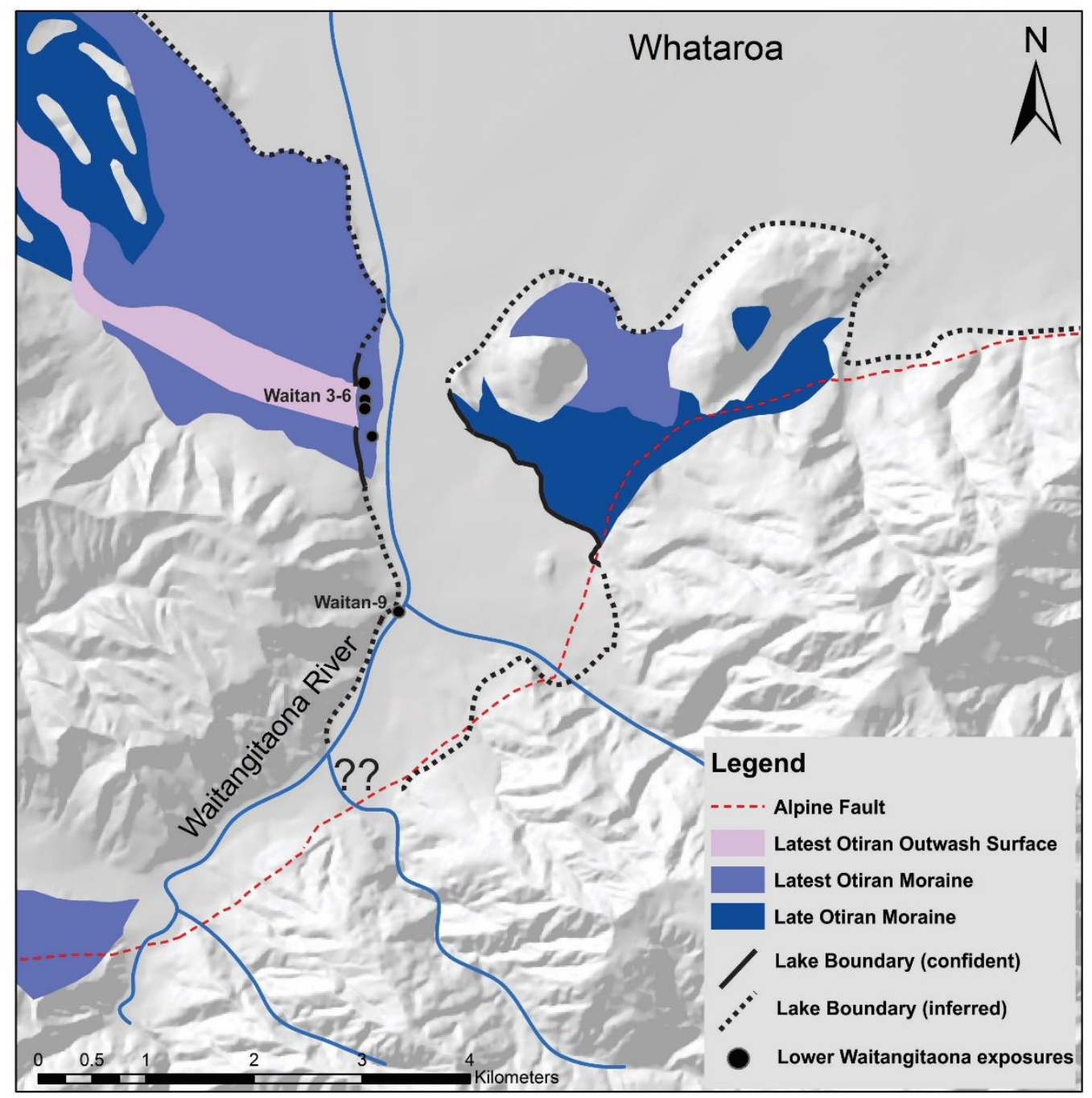

Figure 6.2 Pro-glacial lake extent interpreted from outcrop exposures grouped as the lower Waitangitaona sections. Inferred lake boundary is mapped as confident where mapped proximal to outcrop exposures, or against the mapped extent of Otiran moraines. Lake boundary (inferred) mapped upstream of outcrop exposures where boundary is largely unknown. Downstream of outcrop exposures, lake boundary is mapped against bedrock or Whataroa terminal moraines. Alpine Fault trace mapped by Cox and Barrell (2007), moraine and outwash surfaces mapped by Barrell et al. (2013). Location of Waitangitaona valley in Westland shown in Figure 1.2.

Upstream of reasonably well constrained lake limits, lake extent is largely unknown, but was likely controlled by glacier position, lake level, and the position and volume of sediment upstream of the lake. Downstream of the documented outcrops, the lake extent is constrained by the Whataroa glacier terminal and lateral moraines or outcropping bedrock.

\subsubsection{Association with DFDP-2 sediments}

The lower Waitangitaona section sediments accumulated in the same pro-glacial lake as the DFDP-2 sedimentary sequence, herein termed paleo-lake Whataroa. This interpretation is based on the presence of ice-rafted sandstone and argillite dropstones in the lower Waitangitaona section outcrops, which cannot have come from the 
Waitangitaona catchment, as no sandstone or argillite bedrock is in this region. In the Whataroa catchment however, sandstone and argillite bedrock crops out proximal to the main divide.

No topographic divide exists between the Whataroa piedmont and the lower Waitangitaona field sites. Icebergs were therefore able to travel westwards unimpeded by bedrock topography, to deposit IRD at the lower Waitangitaona field sites. The concentration of dropstones in these outcrops suggests icebergs calving into paleo-lake Whataroa frequently travelled westwards to accumulate in the Waitangitaona river valley.

The main mechanism proposed for the transport of icebergs in this direction is northerly or north-easterly winds. Down-valley katabatic winds may also have driven Whataroa derived icebergs onto the piedmont, to then travel westwards to the Waitangitaona site. Additionally, if the outwash surface mapped by Barrell et al. (2013) represents a lake outflow, currents moving toward the outflow may have assisted in concentrating icebergs toward the lower Waitangitaona section outcrops.

This finding has important implications for the geometry and lake level of paleo-lake Whataroa, as discussed below.

\subsubsection{Implications for paleo-lake Whataroa}

The presence of Whataroa catchment derived ice rafted debris (IRD) in the lower Waitangitaona section outcrops requires that paleo-lake Whataroa extended into Waitangitaona river valley. Connectivity between the two sites implies paleo-lake Whataroa was a large feature, extending to latest Otiran moraine limits in places (Figure $6.3)$. 


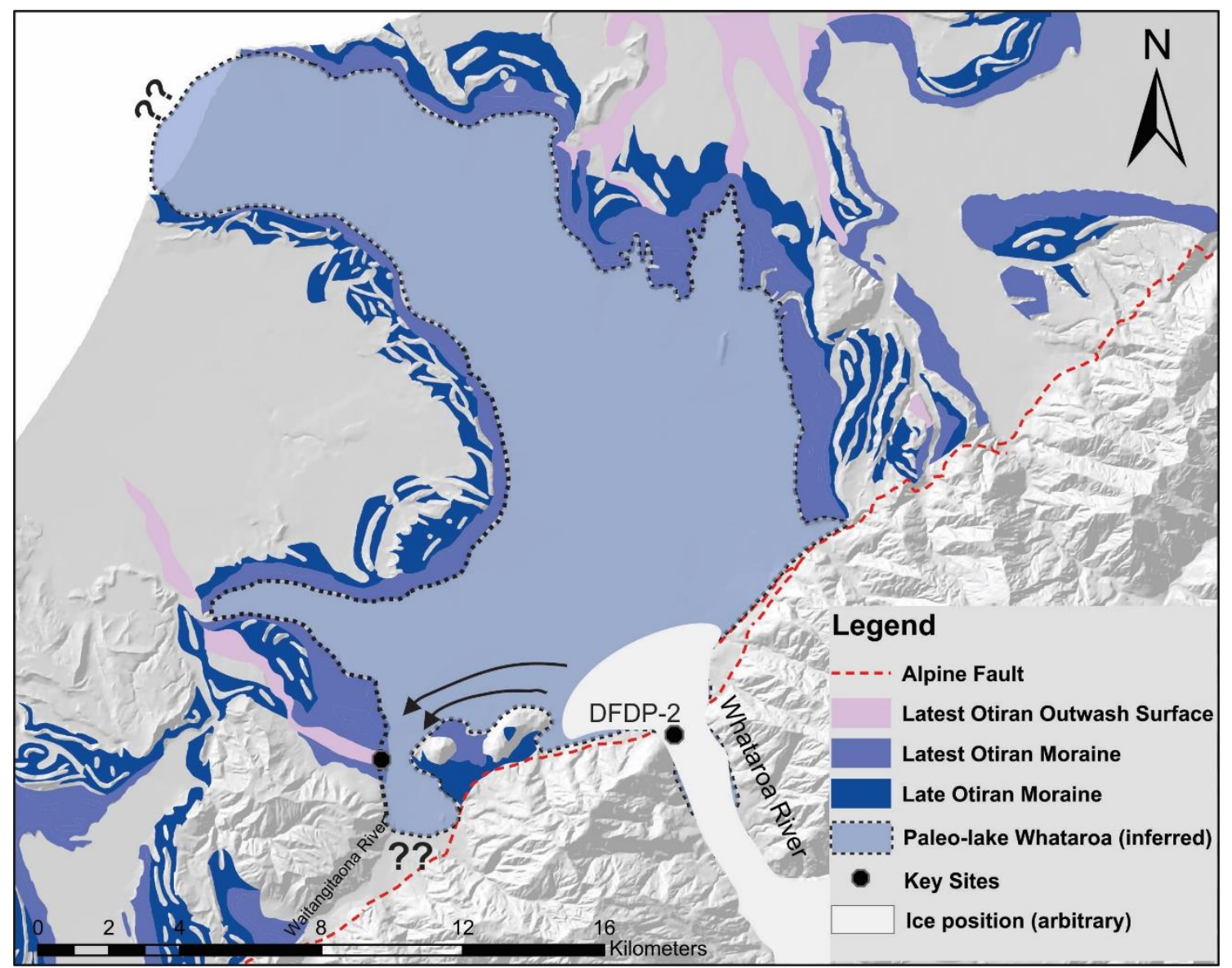

Figure 6.3 Inferred extent of paleo-lake Whataroa, based on position of latest Otiran moraines, remnant moraine dammed lakes, and outcrop exposures of the lower Waitangitaona sections (Denoted as key site). Location of DFDP2 drill site is also displayed. Arbitrary ice position is shown, with transport directions for IRD, supplied to the lower Waitangitaona section outcrops. Lake boundaries marked with question marks are poorly constrained boundaries, due to a lack of any mapped moraine or outcrop record. Alpine Fault trace mapped by Cox and Barrell (2007), moraine and outwash surfaces mapped by Barrell et al. (2013).

This finding also has important implications for the lake level of paleo-lake Whataroa.

Outcrops of the lower Waitangitaona section are situated between $~ 85-97$ metres

AMSL, on the footwall of the Alpine Fault. If the Alpine Fault footwall has not undergone uplift since the latest Otiran (17-20 kyr), the elevation of the paleo-lake bed was $\sim 90$ metres AMSL, and local lake water level at this location must have been higher than this.

Uplift on the Alpine Fault footwall is observed along the South Westland Fault Zone (SWFZ), as a series of reverse throw faults running NE-SW between the Waitangitaona River and the modern coastline, exposed northwards in the Mikonui River (De Pascale et al., 2016, Sutherland, 1996, Cox and Sutherland, 2007). Overall, $3.5 \mathrm{~km}$ of uplift is occurred on the SWFZ since the mid-Miocene ( $<0.5 \mathrm{~mm} / \mathrm{yr})$ (Nathan et al., 1986). Offset of Holocene sediments in the Mikonui River indicates the SWFZ is presently active (De Pascale et al., 2016) . Despite evidence for recent activity, it remains unlikely 
that the lower Waitangitaona section outcrops have been uplifted at rates more than $1^{-3}$ $\mathrm{m} / \mathrm{yr}$ since deposition. Over the past $\sim 19 \mathrm{kyr}$, this equates to a maximum of 19 metres uplift.

The elevation of the lower Waitangitaona section outcrops indicates the water level for paleo-lake Whataroa to range from 65 to at least 97 metres AMSL. At 16,650 cal. yr BP, the date of lake initiation at the DFDP-2 drill-site, global mean sea level was $~ 120$ metres below present (Lambeck et al., 2014). Water level for paleo-lake Whataroa is calculated to have been $>180$ metres above sea level from 16-20 ka, assuming the lower Waitangitaona section outcrops were deposited in the same pro-glacial lake system as the DFDP-2 sedimentary sequence.

\subsubsection{Outcrop exposure at Waitan-9}

Upstream of the lower Waitangitaona section, a glacio-lacustrine sedimentary sequence occurs at field site Waitan-9. This outcrop is overlain by a coarse boulder diamictite, and sits at a higher elevation than the lower Waitangitaona section. This outcrop is inferred to be early Otiran or older, and strongly suggests that pro-glacial lakes formed in the Waitangitaona region during pre MIS-2 glaciations. This inference is unsurprising, given MIS 4, 6 and 8 moraines on the Westland piedmont indicate previous advances were comparable glacial maxima at MIS-2.

\subsection{Whataroa (DFDP-2) sedimentary sequence}

The formation of extensive pro-glacial lakes following glacial retreat in Westland was proposed by Suggate and Almond (2005), based in part on the observation that small remnant lakes persist against LGM terminal and lateral moraines presently. Results presented in Chapter 5 provide compelling evidence that a large pro-glacial lake formed in the Whataroa region. This finding supports the notion that pro-glacial lakes were a major feature on the Westland piedmont following initial glacial retreat.

\subsubsection{Interpreting the DFDP-2 sedimentary sequence}

The glacio-lacustrine sequence recovered by DFDP-2 allows the temporal development of a pro-glacial lake system to be analysed. Pro-glacial lakes in the Westland region were thought to be unique depositional environments due to four main factors: 
— They were formed, fed and influenced by the behavior of maritime glaciers with extremely high rates of mass turnover.

- They were supplied by large catchments with instantaneous erosion rates of up to $500 \mathrm{~mm} / \mathrm{yr}$ (Herman et al., 2015) and mean erosion rates of 10mm/yr.

- Catchments presently received $>10 \mathrm{~m} / \mathrm{yr}$ of precipitation, and likely received similar or slightly less than this during the LGM/LGIT.

- Lakes overlie a major plate boundary fault, accommodating large earthquakes every $291 \pm 23$ years (Cochran et al., 2017).

Due to these factors, the architecture of glacio-lacustrine deposits are expected to differ from those observed in less dynamic regions.

The ice contact and ice distal facies schemes and depositional models are used to interpret deposits in the DFDP-2 sedimentary sequence. Presented in Section 5.5.2, the DFDP-2 section is interpreted as an ice contact depositional environment from 240 to $\sim 130$ metres MD, and an ice distal environment from 130 to 0 metres MD.

\section{Ice contact sedimentation ( 240 to $\sim 130$ metres $\mathrm{MD}$ )}

Formation of a pro-glacial lake on the Whataroa piedmont, which extended upstream to the DFDP-2 drill-site, is attributed to the retreat of the Whataroa glacier from its latest Otiran maximum. Glacial over-deepening, as well as mass loss during retreat created accommodation space for the deposition of glacial diamict. The diamictite unit in the DFDP-2 sequence comprises Gs and Gms type facies, deposited dominantly by subglacial processes. The presence of a silt-clay matrix in the diamictite unit demonstrates that little to no sorting took place during the deposition of this unit. In the DFDP-2 sequence, 33.9 metres of undifferentiated diamict was deposited.

At 206.1 metres MD, an abrupt lithology change from diamictite to siltstone is observed, with no grading or interbedding with siltstone and diamictite facies observed. This suggests that grounding line retreat occurred rapidly, preventing the development of a glacio-lacustrine delta. An alternate explanation is that re-sedimented diamict material forming the delta (Gg facies) was deposited in the 206-240 metres MD interval, and could not be differentiated from Gs and Gms facies in cuttings samples. Irrespective of this, the transition from diamictite to fine grained sediment is attributed to continued terminus retreat upstream of the drill-site. This retreat was likely accelerated by iceberg calving, depositing IRD distal from the ice front. 
Sediment core from the interval 126-159 metres MD shows fine-grained sedimentation in the laminated siltstone unit to be dominated by two main modes of sediment flux:

- Upward fining $\mathrm{mm}$ to $\mathrm{cm}$ scale silt to sand beds comparable to rhythmites (Fl, Flr facies), interpreted as density flow deposits.

- Massive to weakly upward fining sand and silt beds (Sm facies), interpreted as debrite-turbidite deposits.

\section{Upward fining deposits:}

Fine-grained, 0.5-10 cm thick upward fining deposits (Fl/Flr facies) comprise 40-50 percent of silt to sand sized units in the cored interval. An average of 6.8 upward fining deposits are observed per metre of core, with a maximum of 63 per metre in certain core sections. Assuming a mean sedimentation rate of $26 \mathrm{~cm} / \mathrm{yr}$, this corresponds to an average of 1.8 deposits/yr, and a maximum of 17 deposits/yr.

Through comparison with outcrop and published analogues, laminated upward fining beds are interpreted as deposition via density flows, formed due to elevated fluid and sediment discharge events from the Whataroa catchment and glacier.

A modern relationship between storm events, erosion and meltwater discharge was observed in the Waiho catchment by Herman et al. (2015). Similarly, Howarth et al. (2012) relate laminated sediment deposits observed in modern Westland lakes to individual storm events. Density flow deposits are therefore interpreted to represent high precipitation storm events that occurred in the Whataroa catchment.

The number of laminated deposits relative to mean sedimentation rate supports this interpretation, with the frequency of storm events in Westland presenting a likely mechanism for producing multiple upward fining deposits per year. Density flow deposits could also have been produced by meltwater pulses, mass wasting directly into the lake, as well as sub-aqueous delta failure events.

\section{Massive-weakly upward fining deposits:}

Silt-sand sized, 0.3-2.5-metre-thick massive to weakly upward fining deposits (Sm facies) comprise up to 40 percent of the cored interval. Approximately 10-15 Sm type deposits are identified from recovered core, corresponding to an average of less than one deposits per metre of core. Deposits are less common than laminated upward fining 
deposits, though are considerably thicker, implying they are representative of larger magnitude, however less frequent sediment transport events.

Massive to weakly upward fining units identified in DFDP-2 sediment core are interpreted as sub-aqueous debris flow deposits, based on the interpretation of comparable deposits by Bennett et al. (2002). Sub-aqueous debris flows are interpreted as triggered by glacio-lacustrine delta failure events, or mass wasting of colluvial material directly into the lake. Delta failure events can be triggered by tectonic or glacio-tectonic events, or simply by delta instability associated with high sedimentation rates (Lønne, 1995). Importantly, the deposition of Sm type deposits is not directly associated with seismic events, indicated by frequency of deposits relative to sedimentation rates.

\section{Additional deposits}

Minor Fmd and Fl deposits containing lonestone clasts are also identified in the cored interval 126-159 metres MD. These deposits are interpreted as deposited by suspension settling of fine silt-clay particles, and ice rafting respectively. The presence of lonestones interpreted as IRD shows the depositional environment to have been ice contact opposed to ice distal.

The stratigraphy of the DFDP-2 ice contact interval is used to interpret the depositional environment, as well as position relative to the ice front, displayed in Figure 6.4. 


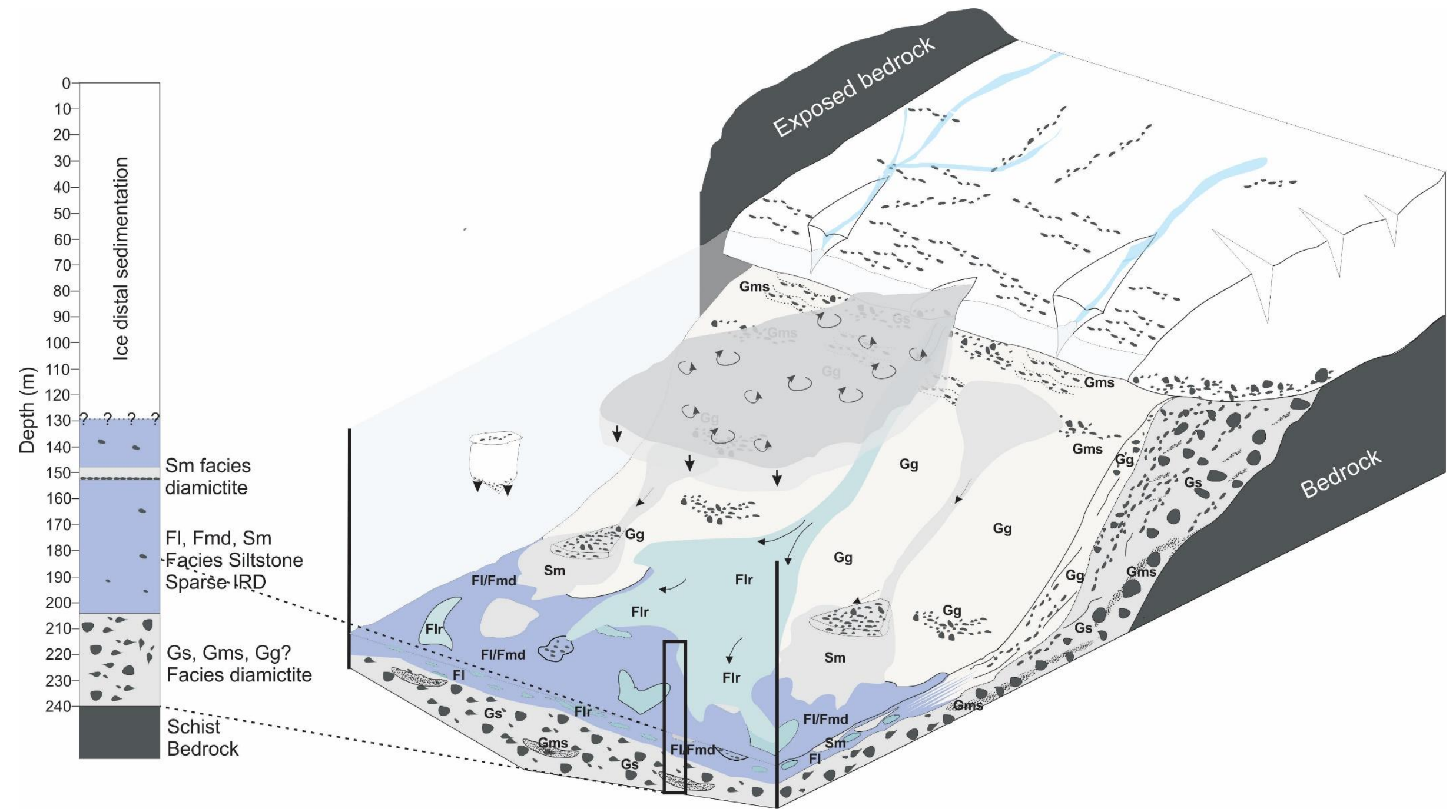

Figure 6.4 Stratigraphy of the DFDP-2 ice contact glacio-lacustrine interval (240 to 130 metres MD), compared to the depositional model developed in Chapter 4. The model is utilised to define location of DFDP-2 section relative to glacier position. Depth interval marking ice contact to ice distal transition is not well constrained. 


\section{Ice distal sedimentation ( 130 to $\sim 10$ metres MD)}

The absence of pebble to cobble clasts (interpreted as IRD) in samples recovered upwards of $\sim 130$ metres is used to mark the transition between ice contact and ice distal sedimentation (Section 5.5). This transition is attributed to continued retreat of the Whataroa glacier terminus, as well as the development of a sub-aerial plain between the glacier and lake body.

Grain-size profiles in samples from 125 to 90 metres MD closely resemble bulk samples from the cored interval (126-159 metres MD), where Fl and Sm facies were deposited in an ice contact depositional environment. The similarity between grain-size profiles between these two intervals shows that despite ice no longer terminating directly into the lake, the processes dominating sediment input to the drill-site remained comparable.

At $~ 80$ metres MD, mean grain-size begins to display progressive upward coarsening from $\sim 20 \mu \mathrm{m}$ to $\sim 200 \mu \mathrm{m}$ at 60 metres MD. Grain-size profiles from 80-60 metres MD closely resemble those from $\mathrm{Sl}$ and $\mathrm{Sr}$ facies identified in the Arahura Cesspool Site (Section 3.2.3), interpreted as deposited on a lacustrine delta toe. This upward coarsening and transition from $\mathrm{Fl} / \mathrm{Sm}$ facies to $\mathrm{Sl} / \mathrm{Sr}$ facies deposition is attributed to a progressive shallowing of the depositional environment, along with progradation of a lacustrine delta over the drill-site. With the interval from 90 to 60 metres MD deposited in 110 \pm 94 yrs, lake shallowing and delta progradation is attributed to high rates of sediment flux to the system.

At 59 metres MD, a transition to pebble to cobble conglomerate is observed. Though difficult to evaluate in cuttings samples, clast size and shape resembles $\mathrm{Gm}$ and $\mathrm{Gc}$ facies identified in aggradational fluvial deposits upstream of the drill-site in the Whataroa valley. This transition is interpreted to represent the progradation of a fluvial depositional environment, overtopping lacustrine delta facies. Stratigraphic inferences suggest the upper gravels at 59-20 metres MD to be deposited between 10-15 kyr (S Cox, 2017, pers.comms), with radiocarbon chronology showing the upper $\sim 20$ metres being deposited in the last 700 yrs. This suggests that periods of fluvial aggradation occurred incrementally in the Whataroa valley, with unconformities existing between the fine-medium sandstone and upper gravels unit, as well as within the upper gravels unit itself. The stratigraphy of the DFDP-2 ice distal interval is used to interpret the depositional environment. (Figure 6.5). 


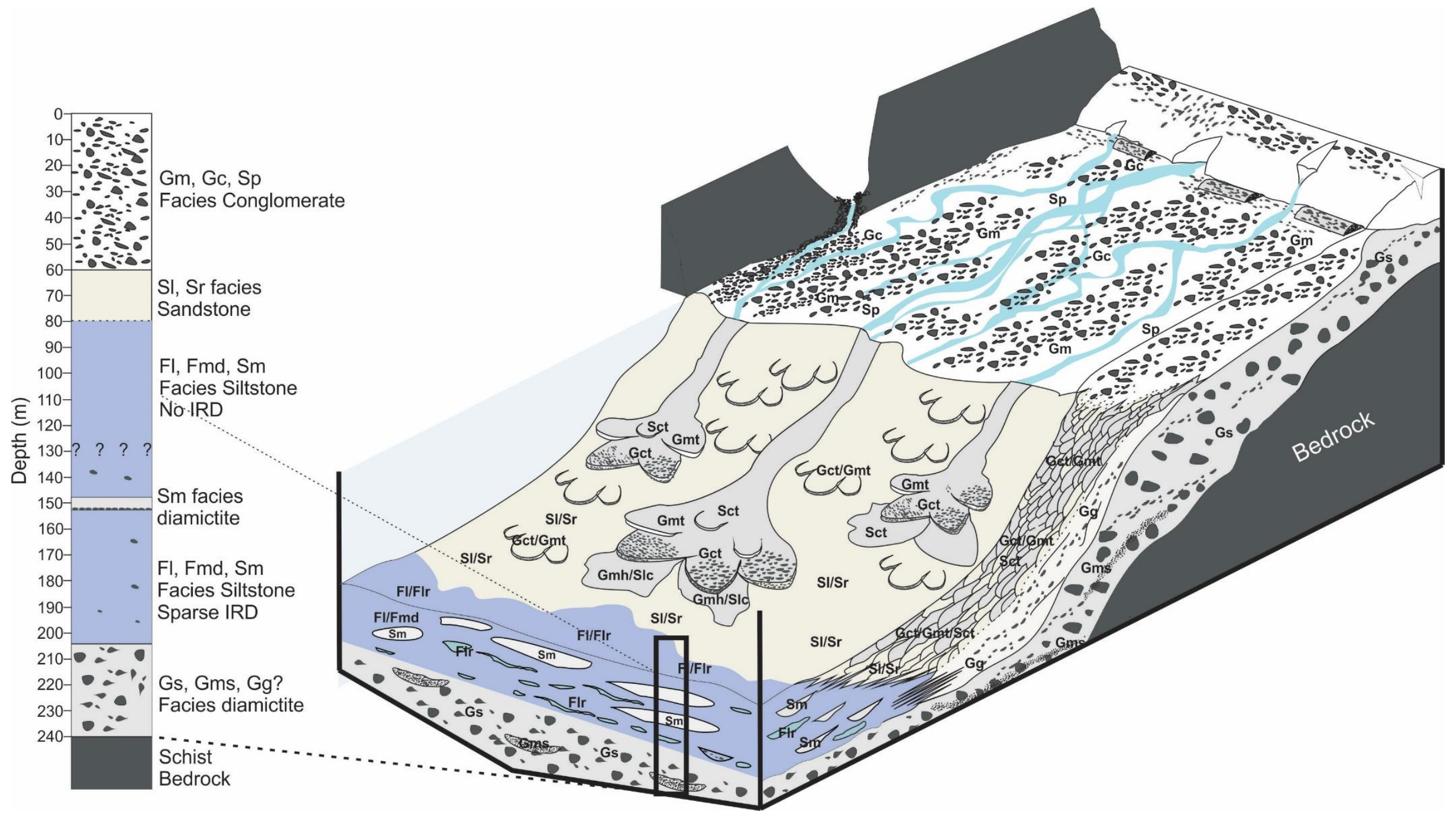

Figure 6.5 Stratigraphy of the DFDP-2 glacio-lacustrine interval ( 130 to 0 metres MD), compared to the depositional model developed in Chapter 4. Model is utilised to define location of DFDP-2 section relative to glacier and lake shoreline. 


\subsubsection{Lake extent}

Geological evidence from the Whataroa and Waitangitaona valleys show the formation of a pro-glacial lake that extended to both sites. Maximum lake extent is displayed in Figure 6.3, which assumes the formation of a single lake body that extended to latest Otiran glacial maxima. This interpretation is supported by the presence of remnant lakes on the Whataroa piedmont, which presently border latest Otiran moraines. The location of these lakes imply that a glacial trough was scoured distally from the glacier accumulation zone, allowing a lake to have formed upon retreat.

Using the constraints outlined, paleo-lake Whataroa is projected to have spanned approximately $190 \mathrm{~km}^{2}$. The exact lake extent is difficult to quantify, influenced by lake level, as well as the location and position of a lake damming feature. The most likely landform to dam paleo-lake Whataroa is the late-latest Otiran terminal moraine, which would have allowed a lake to persist for centuries to millennia. The interpretation of a moraine dammed pro-glacial lake is favored due to the length of the DFDP-2 pro-glacial lake record ( 700 years), making it unlikely for an ice dam to persist for this period.

As discussed in Section 6.2.3, the elevation of glacio-lacustrine deposits in the Waitangitaona River can be used to estimate the lake level of paleo-lake Whataroa. These findings are combined with contemporary uplift rates to estimate water depth during lake formation at DFDP-2 drill-site.

\subsubsection{Lake Depth}

Lake levels of paleo-lake Whataroa are estimated to have been >90 metres AMSL, comparable to the elevation of the DFDP-2 drill-site (98 metres AMSL). The paleo-lake floor at $\sim 16,650$ cal. yr BP, (age of lake initiation at the drill-site), is marked by the contact between basement at the diamictite unit at 240 metres MD. This is used to suggest the minimum lake depth at the drill-site during lake initiation was 240 metres depth.

The DFDP-2 drill-site is situated on the Alpine Fault hanging wall, in the rapidly uplifting central Southern Alps region. Uplift rates of $\sim 10^{-3} \mathrm{~m} / \mathrm{yr}$ are calculated for Whataroa region using thermochronometric methods (Herman et al., 2009), supported by calculated dip-slip rates of $>12^{-3} \mathrm{~m} / \mathrm{yr}$ (Norris and Cooper, 2001). Since lake 
initiation at the drill-site $(\sim 16,650$ cal. yr BP $)$, the paleo-lake floor and overlying sediments have likely experienced approximately 165 metres of uplift.

Lake level constraints from the lower Waitangitaona sites, the depth to basement at DFDP-2, and uplift rates constrain initial lake depth at the DFDP-2 site to be $\sim 400$ metres. Relative to mean sea level at 16,650 cal. yr BP ( 120 metres below present (Lambeck et al., 2014)), lake depth at the DFDP-2 site is estimated at $~ 180$ metres below sea level. Despite this, sediments recovered by DFDP-2 as well as at the lower Waitangitaona field sites display no evidence of marine influence. This demonstrates that the depositional environment was lacustrine opposed to a fjord setting, despite deposition well below sea level.

\subsubsection{Whataroa valley profile}

DFDP-2 drill-holes were deliberately drilled proximal to bedrock slopes on the southern side of the Whataroa valley opposed to in the valley centre, in order to minimize the interval of Quaternary sediments encountered. As a result, the depth to basement at DFDP-2 is likely to be shallower than the maximum depth to basement in the Whataroa valley.

The presence of the $\sim 16.6 \mathrm{kyr}$ diamictite unit overlying bedrock shows that the LGM glacier scoured to bedrock in the Whataroa valley. The simplest assumption is that the basement-sediment interface displays a glacial U-shaped morphology, developed during the LGM, as well as during prior glaciations. This implies that the depth to basement will be greatest in the valley centre, and steepen upwards to the valley walls.

The sub-surface profile of the Whataroa valley has been examined using shallow seismic reflection (Lepine, 2016), and seismic tomography studies using velocity contrasts between basement and overlying sediments to define depth to basement (McNab, 2017). Depending on velocity contours used, basement in the valley centre is estimated to be 400-600 metres below the modern valley floor by McNab (2017). This finding is in agreement with Lepine (2016), who modeled basement down to 550 metres in the valley centre. A best estimate of 550 metres for maximum depth to basement along the cross section line marked in Figure 6.6.

The Whataroa valley profile displayed in Figure 6.7 utilises the same geophysical modelling constraints (McNab, 2017, Lepine, 2016). Both studies model the sub-surface 
bedrock profile in the Whataroa Valley to display an over-deepened, glacially carved "U” shaped valley profile.

The thickness and geometry of sedimentary units are interpreted using DFDP-2 unit depth intervals, as well as the seismic reflection model by Lepine (2016). An S-wave velocity model developed by McNab (2017) identifies three sedimentary units overlying bedrock, corresponding to fluvial gravels, underlying lacustrine silts and a third, basal unit overlying bedrock. The lower contacts of the respective units are estimated at $\sim 120$ metres, 375 metres and a maximum of 600 metres beneath the valley centre. When integrated with unit depth constraints from boreholes DFDP-2A, 2B, units are inferred to thicken considerably toward to the valley centre. This forms contacts sloping at angles of up to $30^{\circ}$ toward the valley centre, producing an unrealistic valley profile.

The interpretation of unit contacts being sub-horizontal, as opposed to sloping toward the valley centre is shown in modelling by Lepine (2016), with the modelled unit geometry producing a more realistic valley profile relative to the findings of this study. Displayed in Figure 6.7, unit contacts are interpreted as being sub-horizontal, sloping at angles of $<5^{\circ}$ toward the valley centre.

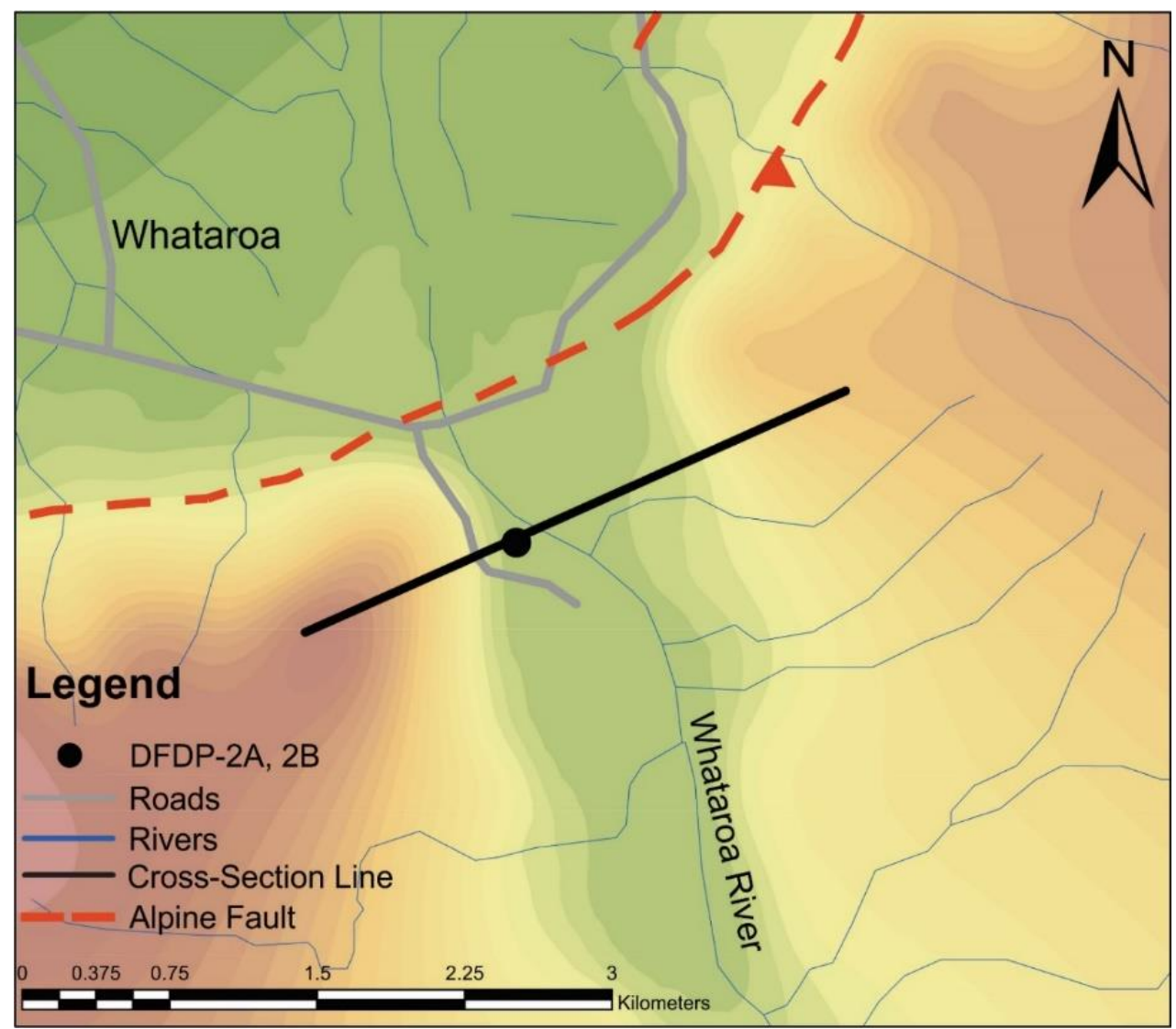

Figure 6.6 Cross section profile used to generate bedrock topographic profile through Whataroa catchment. Simplified elevation model generated through linear interpolation of 15-metre contours (LINZ). 


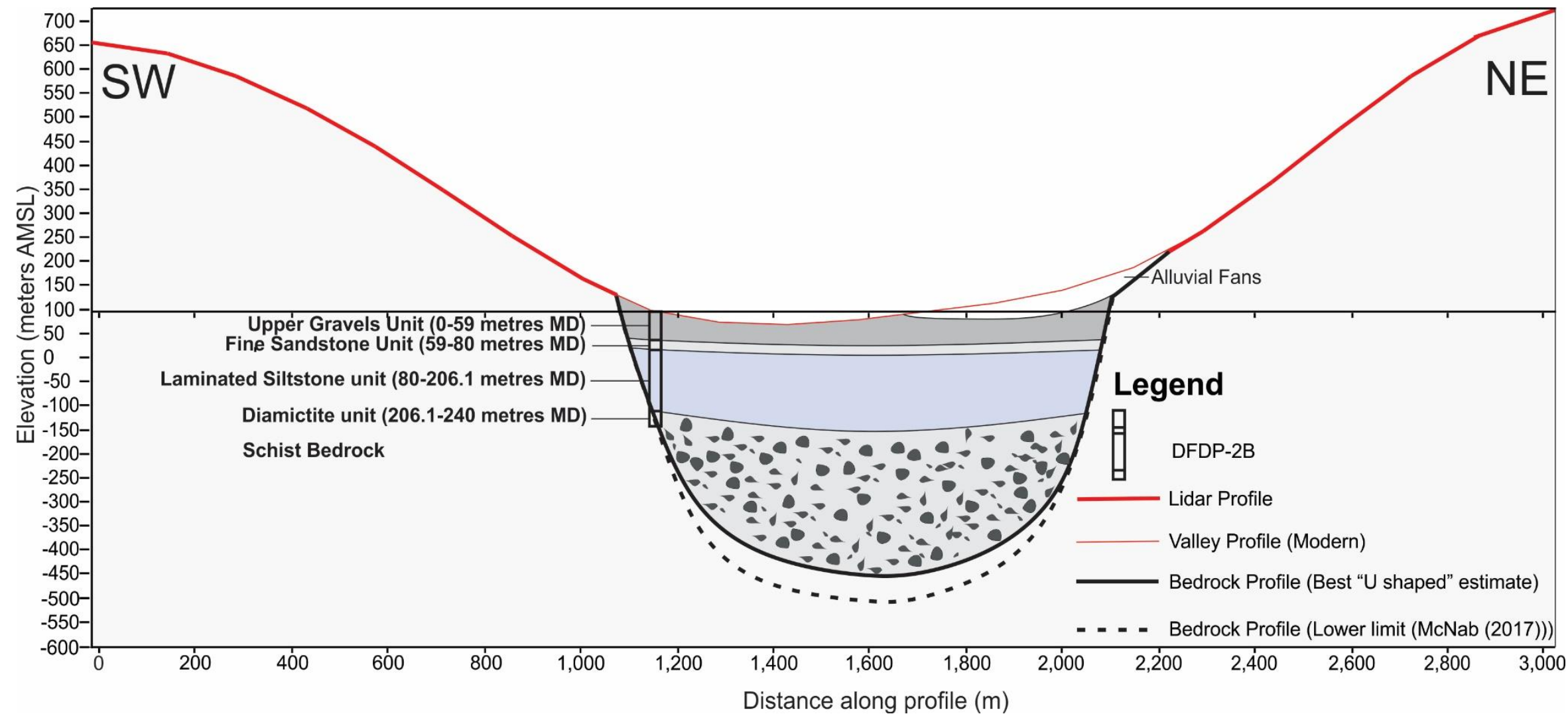

Figure 6.7 Interpreted basement profile in the Whataroa Valley, along transect marked in Figure 6.6. Depth to basement as well as unit geometry educated by models of Lepine (2016) and McNab (2017), as well as observations in boreholes DFDP-2A, 2B. Sub-surface bedrock profile is suggested to display a "U' shaped morphology, though steepens notably in the shallow sub-surface. Note: Plot displays no vertical exaggeration. 


\subsubsection{Implications of the sub-surface profile}

The sub-surface bedrock profile (Figure 6.7) has implications for the post-glacial development of the Whataroa valley. The stratigraphy of the DFDP-2 core shows that during the LGM, the Whataroa glacier scoured to bedrock at the drill-site, depositing a diamict upon retreat. This is used to suggest that the Whataroa glacier scoured to basement across the full sub-surface trough displayed in Figure 6.7, before being infilled during post-glacial retreat.

${ }^{14} \mathrm{C}$ chronology of the DFDP-2 sequence showed accumulation of the diamictite unit initiated at 16,650 cal. yr BP. Assuming that diamict deposition occurred coevally in the valley centre as on the valley walls (at the DFDP-2 drill-site), well-constrained sedimentation rates from the DFDP-2 sequence can be used to estimate sedimentation rates in the valley centre.

At the drill-site, the diamictite, laminated siltstone and fine-medium sandstone units are shown to accumulate in $659 \pm 151 \mathrm{yrs}$, giving a mean sedimentation rate of $0.26 \mathrm{~m} / \mathrm{yr}$. Utilising the unit thicknesses displayed in Figure 6.7, an upper limit for the sedimentation rate in the valley centre is calculated at $\sim 0.66 \mathrm{~m} / \mathrm{yr}$. These calculations rely heavily on the geophysical interpretations of McNab (2017) and Lepine (2016), as well as the stated assumptions regarding chronology and sedimentation. Regardless, these findings are indicative of extremely high sediment accumulation rates following glacial retreat in the Whataroa valley.

\subsubsection{Sedimentation and slope support processes}

Field mapping shows the DFDP-2 drill-site to be situated 110 metres east of a bedrock slope dipping eastwards into the Whataroa valley at $\sim 45^{\circ}$. In order to intercept bedrock at 240 metres MD at DFDP-2B however, bedrock dip angle must steepen to $>70^{\circ}$ in the sub-surface, and sustain this angle for a minimum of 240 metres vertically (Figure 6.7). Near vertical basement proximal to the DFDP-2 drill-site is modelled from gravity measurements, supporting the observations above (Jenkins, 2017).

Reverse faulting of schist basement is a possible cause of the observed over-steepening, though is not noted by the geophysical investigations discussed earlier. Sub-surface over-steepening of bedrock proximal to the DFDP-2 drill-site is attributed to overdeepening during glacial advance. Presently, topographic slope angles of $>70^{\circ}$ are 
highly uncommon in the Southern Alps, though are recognized in recently de-glaciated catchments (Franz Josef, Fox Glacier). In less recently de-glaciated catchments, oversteepened slopes are shown to rapidly re-equilibrate, with failure producing lower slope angles (Augustinus, 1996).

Slope support due to rapid sediment flux, as well as slope exposure below lake level is interpreted to have allowed glacially over-steepened slopes to be maintained. Lake level constraints suggest that much of the exposed glacial trough was below lake level, with slopes being protected from sub-aerial erosion mechanisms such as frost cracking. Additionally, extremely rapid sediment flux to the system acted to support oversteepened slopes and inhibit potential failure. Both processes have allowed bedrock slope angles of $>70^{\circ}$ to be maintained in the sub-surface below the DFDP-2 drill-site.

\subsection{Equilibrium line altitude (ELA) changes during deglaciation.}

The M6 moraine chronology of Suggate and Almond (2005), coupled with nearby palynogical reconstructions (Vandergoes and Fitzsimons, 2003) demonstrate the Whataroa region underwent a transition from glacial advance to retreat between 19-18 kyr. At $\sim 19$ kyr, M6 moraines were deposited at or proximal to the LGM ice maxima on the Whataroa piedmont (Suggate and Almond, 2005). The M6 moraine limits resemble LGM ice maxima for the Whataroa catchment as modelled by Golledge et al. (2012). In this model, LGM ELA values for the Whataroa glacier are calculated at 400-500 metres.

We assume therefore that at $\sim 19 \mathrm{kyr}$ the Whataroa glacier had an ELA of $450 \pm 50$ metres. At this time, there is no evidence to suggest the formation of a lake on the Whataroa piedmont.

To quantify potential ELA change in the Whataroa region during the LGIT period, the simple calculation of temperature change divided by environmental lapse rate ( 4.7 ${ }^{\circ} \mathrm{C} / \mathrm{km}$ (Stuart, 2009)) is used. Temperature reconstructions using biotic proxies from the nearby Okarito Bog show relatively consistent MAT's of $7.5 \pm 1.5^{\circ} \mathrm{C}$ from $19-17$ kyr, with $2 \pm 1.5^{\circ} \mathrm{C}$ of warming then occurring from $\sim 17$ to $\sim 15 \mathrm{kyr}$ (Newnham et al., 2012, Vandergoes et al., 2013). For the period between $17-15 \mathrm{kyr}\left(2 \pm 1.5^{\circ} \mathrm{C}\right.$ warming $)$, $425 \pm 319$ metres of ELA increase is attributable to climate warming based on these 
parameters. At $15 \mathrm{kyr}$, this corresponds to an ELA of $\sim 850-900$ metres for the Whataroa glacier.

To evaluate the withdrawal of the Whataroa Glacier, Dr Frederic Herman (University of Lausanne) developed a series of mass conservation models*. The research in preparation will form collaborative publications with the DFDP-2 science team.

Models are run with progressive ELA increases to simulate ice extent during climate warming. Net accumulation rates of 2 metres/yr and 5 metres/yr are used, with a linear distribution across the simulation area. Comparisons between ice extent for 2 metres/yr and 5 metres/yr are displayed in Figure 6.8.
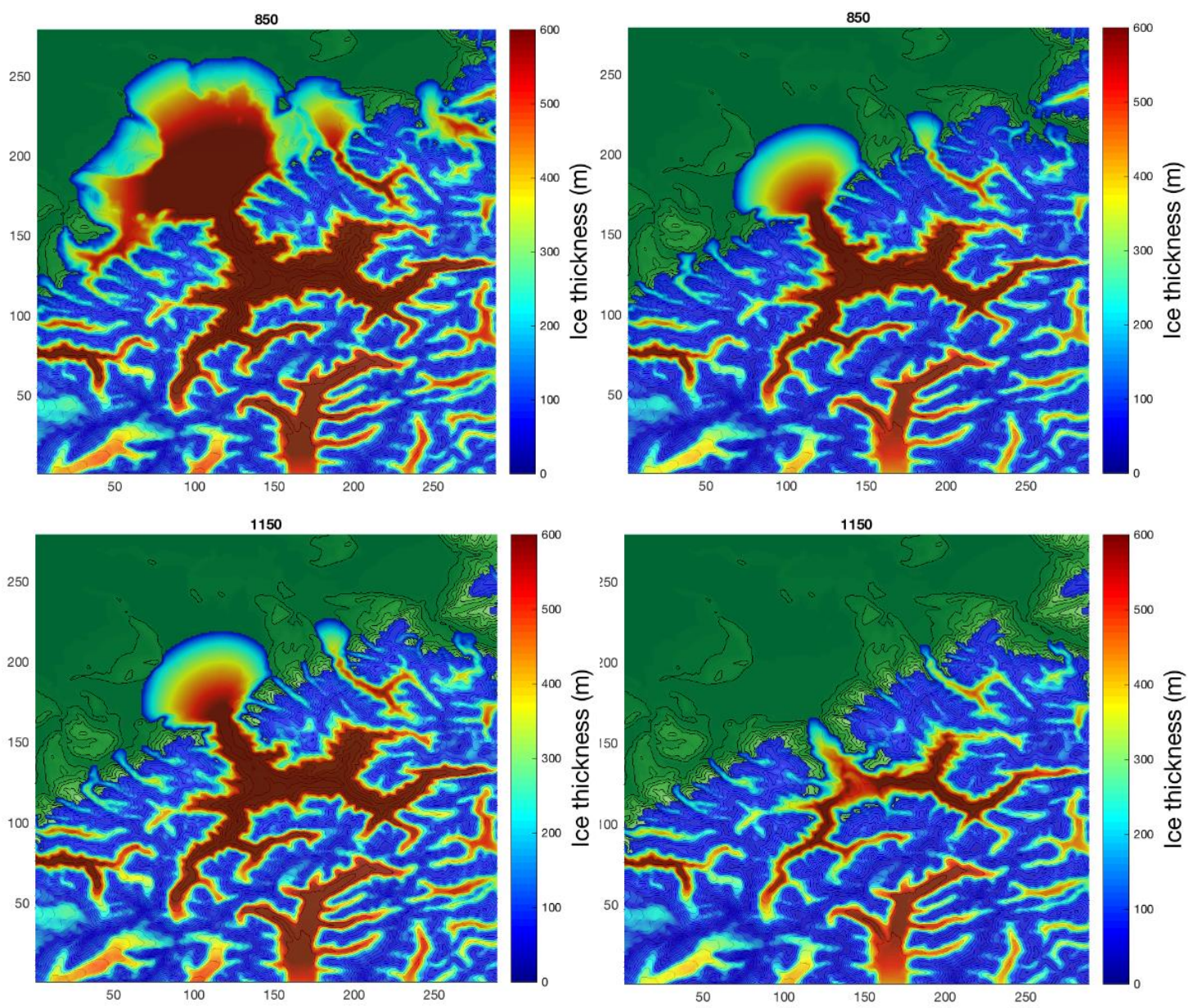

Figure 6.8 Model comparisons for the Whataroa catchment at ELA's of 850 and 1150 metres, for 5 metre/yr (left) and 2 metre/yr (right) accumulation rates.

Of the two model simulations, the 5 metre/yr accumulation rate simulation is argued to better represent last glacial-interglacial transition conditions, with 2 metres/yr representing a significant decline in precipitation from modern rates. Multi-proxy evidence (Golledge et al., 2012, Lorrey et al., 2012) suggests the LGM to be only and providing access to the mass conservation models. 
slightly drier than present. The 5 metre/yr accumulation rate model is therefore preferred.

Using Dr Herman's unpublished model simulations, the ELA at which a lake initiated at the DFDP-2 drill-site can be estimated. The DFDP-2 record shows ice retreating proximal to or upstream of the drill-site by $\sim 16,650$ cal. yr BP. From the culmination of the M6 glacial advance at $\sim 19 \mathrm{kyr}$, this represents $\sim 22$ kilometres of ice retreat across the Whataroa piedmont over $\sim 2.4 \mathrm{kyr}$. Ice extent during lake formation at the drill-site is best represented by model ELA 1350 metres $(5 \mathrm{~m} / \mathrm{yr})$ or 1150 metres $(2 \mathrm{~m} / \mathrm{yr})$ displayed in Figure 6.9.
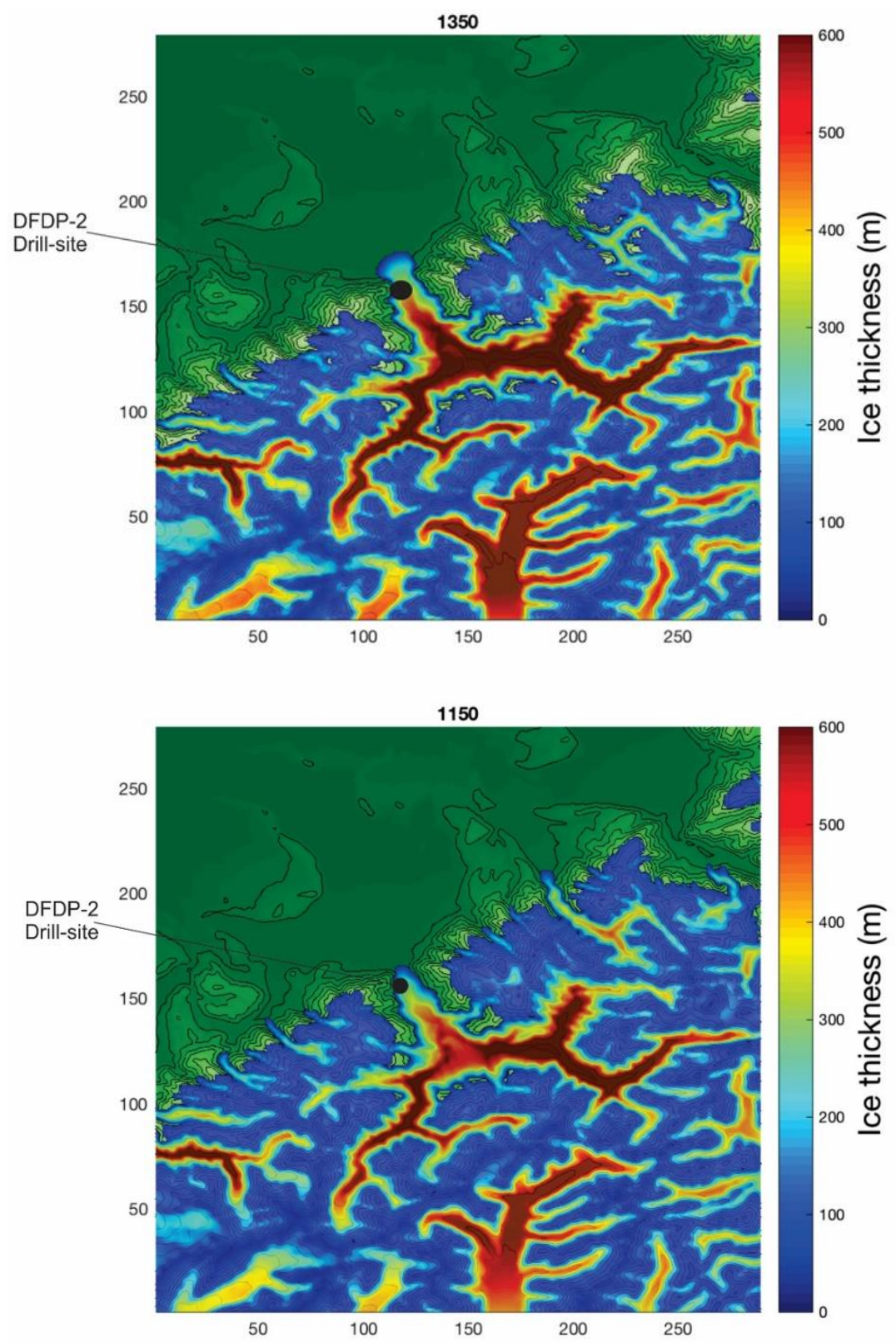

Figure 6.9 Modelled ice extent in the Whataroa Valley at ELA of $1350(5 \mathrm{~m} / \mathrm{yr})$ and $1150(2 \mathrm{~m} / \mathrm{yr})$. 
Modelled ELA for lake initiation at the drill-site can be compared to the calculated ELA based on temperature reconstructions. As presented, assuming an initial ELA for the LGM Whataroa glacier of $450 \pm 50$ metres, at $\sim 15 \mathrm{kyr}$ an ELA of $\sim 850-900$ metres is expected based on $\sim 2{ }^{\circ} \mathrm{C}$ of warming (Figure 6.10)

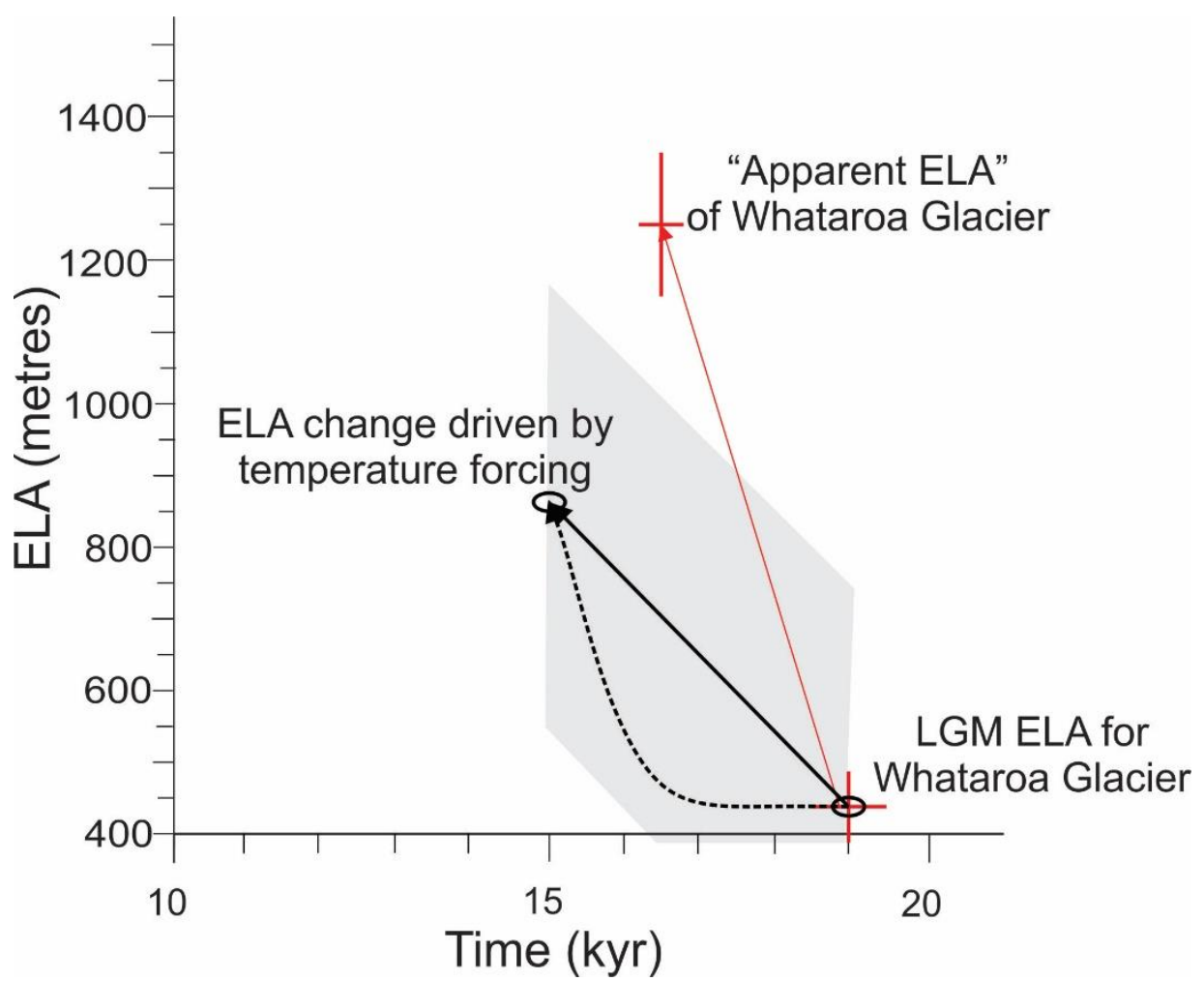

Figure 6.10 ELA vs time diagram for the Whataroa glacier. ELA at $\sim 19 \mathrm{kyr}$ is estimated at $450 \pm 50$ metres based on modelling by Golledge et al. (2012). ELA change due to temperature forcing is based on $2 \pm 1.5^{\circ} \mathrm{C}$ of warming, calculated from palynological records (Newnham et al., 2012), with errors shaded grey. Solid line represents warming initiating at $19 \mathrm{kyr}$, dotted line represents initiating at $17 \mathrm{kyr}$. Apparent ELA of Whataroa glacier uses mass conservation models by Dr Herman (unpublished) to estimate the ELA for lake initiation at the DFDP-2 drill-site.

The discrepancy between the expected ELA for the Whataroa glacier and the apparent ELA for lake initiation at the drill-site suggests that ice extent on the Whataroa piedmont was not solely controlled by temperature forcing. This discrepancy is explained by the development of a pro-glacial lake at the Whataroa glacier toe, driving accelerated glacier terminus retreat and acting to decouple the glacier extent from climatic forcing.

In not including the effects of pro-glacial lake development on ice extent, Dr Herman's mass conservation models are limited in directly evaluating the response of the Whataroa glacier to LGIT climatic change. Despite this, the models remain extremely useful in examining glacier geometry during advance/retreat. 


\subsection{De-glaciation of the Whataroa region}

Ice retreat on the Whataroa piedmont initiated between 18-19 kyr, attributed to glacier mass balance changes associated with latest LGM climate warming. This retreat allowed a terminal moraine dammed pro-glacial lake to develop, likely proximal to the glacier terminus on the Whataroa piedmont. Forming in a temperate region with LGIT mean annual temperatures of $\sim 7.5^{\circ} \mathrm{C}$ (Newnham et al., 2012), initial lake expansion may have been rapid, occurring through expansion mechanisms discussed in Section 1.10.1. The development of a pro-glacial lake acted to decouple glacier mass balance from climatic variables, with dynamic lake processes becoming the dominant control on glacier mass balance.

Glacier terminus retreat and pro-glacial lake expansion across the Whataroa piedmont persisted during the LGIT period, with ice withdrawing upstream of the DFDP-2 drillsite at $\sim 16.6 \mathrm{kyr}$. At a period between $\sim 18.5$ and $\sim 16.5 \mathrm{kyr}$, the pro-glacial lake likely extended westwards, occupying a remnant glacial trough in the Waitangitaona valley. This connectivity allowed Whataroa derived IRD to be carried south-westwards and deposited as part of the lower Waitangitaona section outcrops.

Immediately after ice withdrawal from the drill-site, the DFDP-2 sedimentary sequence was deposited, with high lake levels and extremely high sedimentation rates contributing to the preservation of over-steepened slopes on the presently buried sides of the Whataroa valley. Sediment flux to the system caused the progressive infill of a glacial trough at the drill-site, as the depositional environment evolved from ice contact lacustrine to ice distal deltaic by $\sim 16 \mathrm{kyr}$. At this point the Whataroa glacier may have stabilised upstream of the drill-site and lake shoreline, where bedrock is exposed proximal to the Whataroa-Perth river confluence.

The presence of late glacial $(\sim \mathrm{ACR})$ terminal moraines upstream of the Whataroa-Perth river confluence requires the respective glaciers to have been upstream of the confluence by 14 kyr (Barrell et al., 2013). Peak LGIT warming defined by palynological records is observed at $\sim 15 \mathrm{kyr}$, with MAT estimates within $2{ }^{\circ} \mathrm{C}$ of current MAT's. Glacial minima during the LGIT period were likely attained at $\sim 15 \mathrm{kyr}$ therefore, before undergoing ACR associated re-advance. 
Though the age is not well constrained, the Whataroa valley then underwent periods of fluvial aggradation, depositing fluvial gravels over deltaic sediments. It is likely that fluvial aggradation occurred coevally with fan aggradation from side catchments in the Whataroa valley, producing the well-developed fan terraces presently observed. More recently (>700 years) fluvial aggradation deposited alluvial terraces observed in bank deposits in the Whataroa River. 


\section{Chapter $7 \quad$ Conclusions \& Future Work}

The primary objective of this study was to understand the processes and implications of glacio-lacustrine sedimentation in Westland. To achieve this, glacio-lacustrine sedimentary sequences were identified and analysed in the Waitangitaona and Arahura river valleys. From these sequences, key facies were identified and utilised alongside published research to develop two glacio-lacustrine facies schemes and depositional models for Westland. Utilising the facies scheme and depositional models, along with ${ }^{14} \mathrm{C}$ chronology and sedimentological analysis to interpret the DFDP-2 glacio-lacustrine sedimentary sequence, a series of conclusions were reached:

- The DFDP-2 sedimentary sequence was deposited in a pro-glacial lake system, which formed due to ice retreat from LGM glacial maxima. Geological evidence from glacio-lacustrine deposits at the Waitangitaona field sites shows the proglacial lake to have extended westwards to the Waitangitaona valley. This finding, in conjunction with the location of remnant lakes, is used to infer the formation of a unified, $\sim 190-\mathrm{km}^{2}$ lake on the Whataroa piedmont.

- Deposition occurred during the Last Glacial-Interglacial Period, with the deposition of a basal diamictite at $\sim 16,650$ cal. yr BP, occurring coevally with glacier retreat proximal to, or upstream of the drill-site. The depositional environment then evolved from an ice contact to an ice distal environment, with the deposition of an extensive interval of lacustrine silt and sand units. Proglacial lake infill and lacustrine delta progradation then caused the depositional environment to evolve to a lacustrine delta by $\sim 16,000 \mathrm{cal}$. yr BP.

$-{ }^{14} \mathrm{C}$ chronology show the deposition of the $\sim 180$-metre glacio-lacustrine sequence to have occurred in $659 \pm 151 \mathrm{yrs}$, demonstrating exceptionally high sediment accumulation rates at the drill-site. Sediment flux, as well as high lake levels allowed the preservation of over-steepened bedrock slopes in the 
Whataroa valley, allowing slope angles of $>70^{\circ}$ to be sustained beneath the present Whataroa valley floor.

- The presence of Alpine Fault offset lacustrine sedimentary sequences in the Arahura valley, in addition to deposits in the Waitangitaona valleys implies that formation of piedmont lakes in response to glacial retreat may have been common in Westland.

\section{Future work}

This research identified several opportunities for further research to be carried out. Recommendations for future research include:

- Further analysis of the DFDP-2 sedimentary sequence. In recovering 240 metres of sediments from two boreholes, DFDP-2 sedimentary samples could be utilised for extremely high-resolution palynological and biological proxy records through the LGIT period. These proxies could be utilised to better understand climate or vegetation changes associated with glacial retreat in Westland.

- Identify and describe additional paleo-lake sequences in the Westland region. Several catchments and piedmonts display similar geometry to the Whataroa or Arahura valleys, so the potential for paleo-lakes to have formed in several Westland catchments is apparent. Further fieldwork or drilling in valleys such as the Wanganui, Karangarua or Hokitika could seek to identify glacio-lacustrine sequences and constrain paleo-lake formation regionally in Westland.

- Further testing of the two facies schemes and depositional models developed for glacio-lacustrine sedimentation in Westland. Should additional fieldwork or drilling identify other glacio-lacustrine sequences in Westland, the facies schemes and depositional models developed could be used to interpret the sequences. This additional testing may further validate the models developed, or provide extra insights into glacio-lacustrine deposition in Westland. 


\section{References}

ALLEN, J. R. 1971. A theoretical and experimental study of climbing-ripple cross-lamination, with a field application to the Uppsala esker. Geografiska Annaler. Series A. Physical Geography, 157-187.

ALLEN, S. K., COX, S. C. \& OWENS, I. F. 2011. Rock avalanches and other landslides in the central Southern Alps of New Zealand: a regional study considering possible climate change impacts. Landslides, 8, 33-48.

ALLOWAY, B. V., LOWE, D. J., BARRELL, D. J. A., NEWNHAM, R. M., ALMOND, P. C., AUGUSTINUS, P. C., BERTLER, N. A. N., CARTER, L., LITCHFIELD, N. J., MCGLONE, M. S., SHULMEISTER, J., VANDERGOES, M. J. \& WILLIAMS, P. W. 2007. Towards a climate event stratigraphy for New Zealand over the past 30000 years (NZ-INTIMATE project). Journal of Quaternary Science, 22, 9-35.

ALMOND, P., MOAR, N. \& LIAN, O. 2001. Reinterpretation of the glacial chronology of South Westland, New Zealand. New Zealand Journal of Geology and Geophysics, 44, $1-15$.

ANDERSON, B. \& MACKINTOSH, A. 2006. Temperature change is the major driver of lateglacial and Holocene glacier fluctuations in New Zealand. Geology, 34, 121-124.

ANDERSON, B. \& MACKINTOSH, A. 2012. Controls on mass balance sensitivity of maritime glaciers in the Southern Alps, New Zealand: The role of debris cover. Journal of Geophysical Research: Earth Surface, 117, n/a-n/a.

APPLEBY, J. R., BROOK, M. S., VALE, S. S. \& MACDONALD-CREEVEY, A. M. 2010. Structural glaciology of a temperate maritime glacier: Lower Fox Glacier, New Zealand. Geografiska annaler: series a, physical geography, 92, 451-467.

ATKINS, C. B. 2003. Characteristics of Striae and Clast Shape in Glacial and Non-Glacial Environments. unpublished $\mathrm{PhD}$ Thesis, Victoria University of Wellington.

AUGUSTINUS, P. Rock mass strength and the stability of some glacial valley slopes. International Journal of Rock Mechanics and Mining Sciences and Geomechanics Abstracts, 1996. 28A-29A.

BAISDEN, W. T., PRIOR, C. A., CHAMBERS, D., CANESSA, S., PHILLIPS, A., BERTRAND, C., ZONDERVAN, A., TURNBULL, J. C., KAISER, J. \& BRUHN, F. 2013. Rafter radiocarbon sample preparation and data flow: Accommodating enhanced throughput and precision. Nuclear Instruments and Methods in Physics Research Section B: Beam Interactions with Materials and Atoms, 294, 194-198.

BARRELL, D. J. A. 2011. Quaternary Glaciations of New Zealand. In: J. EHLERS, P. L. G., P.D HUGHES (ed.) Quaternary Glaciations- Extent and Chronology: A closer look. Amsterdam: Elsevier.

BARRELL, D. J. A., ALLOWAY, B., SHULMEISTER, J. \& NEWNHAM, R. 2005. Towards a climate event stratigraphy for New Zealand over the past 30,000 years. Institute of Geological and Nuclear Sciences Science Report, 7, 12.

BARRELL, D. J. A., ANDERSEN, B. G., DENTON, G. H. \& LYTTLE, B. S. 2013. Glacial Geomorphology of the Central South Island, New Zealand: Digital Data, GNS Science.

BARRETT, P. 1980. The shape of rock particles, a critical review. Sedimentology, 27, 291-303.

BATT, G. E., BRAUN, J., KOHN, B. P. \& MCDOUGALL, I. 2000. Thermochronological analysis of the dynamics of the Southern Alps, New Zealand. Geological Society of America Bulletin, 112, 250-266.

BENN, D. I. \& BALLANTYNE, C. K. 1993. The description and representation of particle shape. Earth Surface Processes and Landforms, 18, 665-672. 
BENN, D. I., WARREN, C. R. \& MOTTRAM, R. H. 2007. Calving processes and the dynamics of calving glaciers. Earth-Science Reviews, 82, 143-179.

BENNETT, M. R., HUDDART, D. \& THOMAS, G. S. P. 2002. Facies architecture within a regional glaciolacustrine basin: Copper River, Alaska. Quaternary Science Reviews, 21, 2237-2279.

BEYSSAC, O., COX, S. C., VRY, J. \& HERMAN, F. 2016. Peak metamorphic temperature and thermal history of the Southern Alps (New Zealand). Tectonophysics, 676, 229-249.

BRAITHWAITE, R. J., ZHANG, Y. \& RAPER, S. 2002. Temperature sensitivity of the mass balance of mountain glaciers and ice caps as a climatological characteristic. Zeitschrift fur Gletscherkunde und Glazialgeologie, 38, 35-61.

BROOK, M., HAGG, W. \& WINKLER, S. 2017. Contrasting medial moraine development at adjacent temperate, maritime glaciers: Fox and Franz Josef Glaciers, South Westland, New Zealand. Geomorphology, 290, 58-68.

BROOK, M. S., HAGG, W. \& WINKLER, S. 2013. Debris cover and surface melt at a temperate maritime alpine glacier: Franz Josef Glacier, New Zealand. New Zealand Journal of Geology and Geophysics, 56, 27-38.

CALLARD, S. L. 2011. The Last Glacial Maximum and Deglaciation in Southern New Zealand: New Pollen-Climate Reconstructions. PhD, Victoria University of Wellington.

CANT, D. J. \& WALKER, R. G. 1978. Fluvial processes and facies sequences in the sandy braided South Saskatchewan River, Canada. Sedimentology, 25, 625-648.

CARRIVICK, J. L. \& RUSHMER, E. L. 2009. Inter-and intra-catchment variations in proglacial geomorphology: an example from Franz Josef Glacier and Fox Glacier, New Zealand. Arctic, Antarctic, and Alpine Research, 41, 18-36.

CARRIVICK, J. L. \& TWEED, F. S. 2013. Proglacial lakes: character, behaviour and geological importance. Quaternary Science Reviews, 78, 34-52.

CHINN, T. 2001. Distribution of the glacial water resources of New Zealand. Journal of Hydrology (New Zealand), 139-187.

CHINN, T. J., HEYDENRYCH, C. \& SALINGER, M. J. 2005. Use of the ELA as a practical method of monitoring glacier response to climate in New Zealand's Southern Alps. Journal of Glaciology, 51, 85-95.

CLARK, P. U., DYKE, A. S., SHAKUN, J. D., CARLSON, A. E., CLARK, J., WOHLFARTH, B., MITROVICA, J. X., HOSTETLER, S. W. \& MCCABE, A. M. 2009. The last glacial maximum. science, 325, 710-714.

COCHRAN, U. A., CLARK, K. J., HOWARTH, J. D., BIASI, G. P., LANGRIDGE, R. M., VILLAMOR, P., BERRYMAN, K. R. \& VANDERGOES, M. J. 2017. A plate boundary earthquake record from a wetland adjacent to the Alpine fault in New Zealand refines hazard estimates. Earth and Planetary Science Letters, 464, 175-188.

COOPER, A. \& IRELAND, T. 2013. Cretaceous sedimentation and metamorphism of the western Alpine Schist protoliths associated with the Pounamu Ultramafic Belt, Westland, New Zealand. New Zealand Journal of Geology and Geophysics, 56, 188199.

COX, S. \& BARRELL, D. 2007. Geology of the Aoraki area, Institute of Geological and Nuclear Sciences 1: 250000 Geological Map. Lower Hutt, New Zealand (GNS Science), 71.

COX, S. \& NIBOUREL, L. 2015. Bedload composition, transport and modification in rivers of Westland, New Zealand, with implications for the distribution of alluvial pounamu (jade). New Zealand Journal of Geology and Geophysics, 58, 154-175.

COX, S. C., STIRLING, M. W., HERMAN, F., GERSTENBERGER, M. \& RISTAU, J. 2012. Potentially active faults in the rapidly eroding landscape adjacent to the Alpine Fault, central Southern Alps, New Zealand. Tectonics, 31, n/a-n/a.

COX, S. C. \& SUTHERLAND, R. 2007. Regional geological framework of South Island, New Zealand, and its significance for understanding the active plate boundary. A continental plate boundary: tectonics at South Island, New Zealand, 19-46.

COX, S. C., THOMAS, A. M., HOWARTH, J., ATKINS, C. B., SUTHERLAND, R., UPTON, P. \& LANGRIDGE, R. Record of Alpine Fault hangingwall erosion in post-glacial 
sediments of the DFDP-2 drillholes. NZ-Japan Joint Research Programme Workshop, 2016 Takayama, Japan.

DE PASCALE, G. P., CHANDLER-YATES, N., DELA PENA, F., WILSON, P., MAY, E., TWISS, A. \& CHENG, C. 2016. Active tectonics west of New Zealand's Alpine Fault: South Westland Fault Zone activity shows Australian Plate instability. Geophysical Research Letters, 43, 3120-3125.

DELMONTE, B., PETIT, J. \& MAGGI, V. 2002. Glacial to Holocene implications of the new 27000-year dust record from the EPICA Dome C (East Antarctica) ice core. Climate Dynamics, 18, 647-660.

DREWRY, D. 1986. Glacial geologic processes, Edward Arnold Baltimore.

DROST, F., RENWICK, J., BHASKARAN, B., OLIVER, H. \& MCGREGOR, J. 2007. A simulation of New Zealand's climate during the Last Glacial Maximum. Quaternary Science Reviews, 26, 2505-2525.

DUNBAR, G. \& BARRETT, P. 2005. Estimating palaeobathymetry of wave-graded continental shelves from sediment texture. Sedimentology, 52, 253-269.

ELDERFIELD, H., FERRETTI, P., GREAVES, M., CROWHURST, S., MCCAVE, I., HODELL, D. \& PIOTROWSKI, A. 2012. Evolution of ocean temperature and ice volume through the mid-Pleistocene climate transition. Science, 337, 704-709.

EYLES, C., EYLES, N. \& MIALL, A. 1985. Models of glaciomarine sedimentation and their application to the interpretation of ancient glacial sequences. Palaeogeography, Palaeoclimatology, Palaeoecology, 51, 15-84.

EYLES, N., CLARK, B. M. \& CLAGUE, J. J. 1987. Coarse-grained sediment gravity flow facies in a large supraglacial lake. Sedimentology, 34, 193-216.

EYLES, N., EYLES, C. H. \& MIALL, A. D. 1983. Lithofacies types and vertical profile models; an alternative approach to the description and environmental interpretation of glacial diamict and diamictite sequences. Sedimentology, 30, 393-410.

FISHER, L., GAZLEY, M. F., BAENSCH, A., BARNES, S. J., CLEVERLEY, J. \& DUCLAUX, G. 2014. Resolution of geochemical and lithostratigraphic complexity: a workflow for application of portable X-ray fluorescence to mineral exploration. Geochemistry: Exploration, Environment, Analysis, 14, 149-159.

GAGE, M. 1985. Glaciation in New Zealand - the first century of research. Quaternary Science Reviews, 4, 189-214.

GAZLEY, M. F., VRY, J. K., DU PLESSIS, E. \& HANDLER, M. R. 2011. Application of portable X-ray fluorescence analyses to metabasalt stratigraphy, Plutonic Gold Mine, Western Australia. Journal of Geochemical Exploration, 110, 74-80.

GIERLOWSKI-KORDESCH, E. 2004. Paleolimnology: the history and evolution of lake systems. BioOne.

GOLLEDGE, N. R., MACKINTOSH, A. N., ANDERSON, B. M., BUCKLEY, K. M., DOUGHTY, A. M., BARRELL, D. J. A., DENTON, G. H., VANDERGOES, M. J., ANDERSEN, B. G. \& SCHAEFER, J. M. 2012. Last Glacial Maximum climate in New Zealand inferred from a modelled Southern Alps icefield. Quaternary Science Reviews, 46, 30-45.

GRIFFITHS, G. A. 1979. High sediment yields from major rivers of the western Southern Alps, New Zealand. Nature, 282, 61-63.

GRIFFITHS, G. A. \& MCSAVENEY, M. 1983. Distribution of mean annual precipitation across some steepland regions of New Zealand. New Zealand journal of science, 26, 197-209.

HAMBREY, M. J. 1994. Glacial environments, UBC Press.

HAMBREY, M. J. \& EHRMANN, W. 2004. Modification of sediment characteristics during glacial transport in high-alpine catchments: Mount Cook area, New Zealand. Boreas, 33, 300-318.

HENDERSON, R. \& THOMPSON, S. 1999. Extreme rainfalls in the Southern Alps of New Zealand. Journal of Hydrology (New Zealand), 309-330. 
HERMAN, F., BEYSSAC, O., BRUGHELLI, M., LANE, S. N., LEPRINCE, S., ADATTE, T., LIN, J. Y., AVOUAC, J.-P. \& COX, S. C. 2015. Erosion by an Alpine glacier. Science, 350, 193-195.

HERMAN, F., COX, S. C. \& KAMP, P. J. J. 2009. Low-temperature thermochronology and thermokinematic modeling of deformation, exhumation, and development of topography in the central Southern Alps, New Zealand. Tectonics, 28, n/a-n/a.

HERMAN, F., RHODES, E. J., BRAUN, J. \& HEINIGER, L. 2010. Uniform erosion rates and relief amplitude during glacial cycles in the Southern Alps of New Zealand, as revealed from OSL-thermochronology. Earth and Planetary Science Letters, 297, 183-189.

HICKS, D. M., HILL, J. \& SHANKAR, U. 1996. Variation of suspended sediment yields around New Zealand: the relative importance of rainfall and geology. IAHS publication, 149-156.

HOVIUS, N., STARK, C. P. \& ALLEN, P. A. 1997. Sediment flux from a mountain belt derived by landslide mapping. Geology, 25, 231-234.

HOWARTH, J. D., FITZSIMONS, S. J., NORRIS, R. J. \& JACOBSEN, G. E. 2012. Lake sediments record cycles of sediment flux driven by large earthquakes on the Alpine fault, New Zealand. Geology, 40, 1091-1094.

JENKINS, S. 2017. A gravity analysis of the Alpine Fault and the DFDP-2 drill site, Whataroa valley, South Westland, South Island, New Zealand. Master's Master's Thesis, Victoria University of Wellington.

JOHNSEN, S. J., DAHL-JENSEN, D., GUNDESTRUP, N., STEFFENSEN, J. P., CLAUSEN, H. B., MILLER, H., MASSON-DELMOTTE, V., SVEINBJÖRNSDOTTIR, A. E. \& WHITE, J. 2001. Oxygen isotope and palaeotemperature records from six Greenland ice-core stations: Camp Century, Dye-3, GRIP, GISP2, Renland and NorthGRIP. Journal of Quaternary Science, 16, 299-307.

KIRKBRIDE, M. P. 1993. The temporal significance of transitions from melting to calving termini at glaciers in the central Southern Alps of New Zealand. The Holocene, 3, 232240.

KLAHN, A. P. 2011. Site characterisation of the Whataroa Valley for the Deep Alpine Fault Drilling Project stage 2 (DFDP-2), West Coast, New Zealand.

KORUP, O., DENSMORE, A. L. \& SCHLUNEGGER, F. 2010. The role of landslides in mountain range evolution. Geomorphology, 120, 77-90.

LAMBECK, K., ROUBY, H., PURCELL, A., SUN, Y. \& SAMBRIDGE, M. 2014. Sea level and global ice volumes from the Last Glacial Maximum to the Holocene. Proceedings of the National Academy of Sciences, 111, 15296-15303.

LANGRIDGE, R., VILLAMOR, P., BASILI, R., ALMOND, P., MARTINEZ-DIAZ, J. \& CANORA, C. 2010. Revised slip rates for the Alpine fault at Inchbonnie: Implications for plate boundary kinematics of South Island, New Zealand. Lithosphere, 2, 139-152.

LEOPOLD, L. B., WOLMAN, M. G. \& MILLER, J. P. 2012. Fluvial processes in geomorphology, Courier Corporation.

LEPINE, P. R. W. 2016. Shallow Seismic Survey of the Whataroa Glacial Valley in the vicinity of the Alpine Fault, Westland. University of Otago.

LISIECKI, L. E. \& RAYMO, M. E. 2005. A Pliocene-Pleistocene stack of 57 globally distributed benthic $\delta 18 \mathrm{O}$ records. Paleoceanography, 20.

LITTLE, T., HOLCOMBE, R. \& ILG, B. 2002. Ductile fabrics in the zone of active oblique convergence near the Alpine Fault, New Zealand: identifying the neotectonic overprint. Journal of Structural Geology, 24, 193-217.

LITTLE, T. A., COX, S., VRY, J. K. \& BATT, G. 2005. Variations in exhumation level and uplift rate along the obliqu-slip Alpine fault, central Southern Alps, New Zealand. Geological Society of America Bulletin, 117, 707-723.

LØNNE, I. 1995. Sedimentary facies and depositional architecture of ice-contact glaciomarine systems. Sedimentary Geology, 98, 13-43.

LORREY, A. M., VANDERGOES, M., ALMOND, P., RENWICK, J., STEPHENS, T., BOSTOCK, H., MACKINTOSH, A., NEWNHAM, R., WILLIAMS, P. W., ACKERLEY, D., NEIL, H. \& FOWLER, A. M. 2012. Palaeocirculation across New 
Zealand during the last glacial maximum at $\sim 21 \mathrm{ka}$. Quaternary Science Reviews, 36, 189-213.

MAGER, S. \& FITZSIMONS, S. 2007. Formation of glaciolacustrine Late Pleistocene end moraines in the Tasman Valley, New Zealand. Quaternary Science Reviews, 26, 743758.

MARRA, M., SHULMEISTER, J. \& SMITH, E. 2006. Reconstructing temperature during the Last Glacial Maximum from Lyndon Stream, South Island, New Zealand using beetle fossils and maximum likelihood envelopes. Quaternary Science Reviews, 25, 18411849.

MCKINNON, K. A. 2011. The Role of Climate and Bed Topography on the Evolution of the Tasman Glacier Since the Last Glacial Maximum.

MCNAB, A. 2017. Velocity structure of the Whataroa Valley using Ambient Noise Tomography.

MIX, A. C., BARD, E. \& SCHNEIDER, R. 2001. Environmental processes of the ice age: land, oceans, glaciers (EPILOG). Quaternary Science Reviews, 20, 627-657.

MOAR, N. \& SUGGATE, R. 1996. Vegetation history from the Kaihinu (last) interglacial to the present, West Coast, South Island, New Zealand. Quaternary Science Reviews, 15, 521-547.

MORTIMER, N. 2000. Metamorphic discontinuities in orogenic belts: example of the garnetbiotite-albite zone in the Otago Schist, New Zealand. International journal of earth sciences, 89, 295-306.

MORTIMER, N., RATTENBURY, M. S., KING, P. R., BLAND, K. J., BARRELL, D. J. A., BACHE, F., BEGG, J. G., CAMPBELL, H. J., COX, S. C., CRAMPTON, J. S., EDBROOKE, S. W., FORSYTH, P. J., JOHNSTON, M. R., JONGENS, R., LEE, J. M., LEONARD, G. S., RAINE, J. I., SKINNER, D. N. B., TIMM, C., TOWNSEND, D. B., TULLOCH, A. J., TURNBULL, I. M. \& TURNBULL, R. E. 2014. High-level stratigraphic scheme for New Zealand rocks. New Zealand Journal of Geology and Geophysics, 57, 402-419.

NATHAN, S., ANDERSON, H. J., COOK, R. A., HERZER, R., HOSKINS, R., RAINE, J. \& SMALE, D. 1986. Cretaceous and Cenozoic sedimentary basins of the West Coast region, South Island, New Zealand, Science Information Pub. Centre, DSIR, for the New Zealand Geological Survey.

NATHAN, S., RATTENBURY, M. S. \& SUGGATE, R. P. 2002. Geology of the Greymouth Area: 1: 250 000, Institute of Geological \& Nuclear Sciences.

NELSON, C. S., COOKE, P. J., HENDY, C. H. \& CUTHBERTSON, A. M. 1993.

Oceanographic and climatic changes over the past 160,000 years at Deep Sea Drilling Project Site 594 off southeastern New Zealand, southwest Pacific Ocean.

Paleoceanography, 8, 435-458.

NEWNHAM, R. M., LOWE, D. J., GILES, T. \& ALLOWAY, B. V. 2007. Vegetation and climate of Auckland, New Zealand, since ca. 32000 cal. yr ago: support for an extended LGM. Journal of Quaternary Science, 22, 517-534.

NEWNHAM, R. M., VANDERGOES, M. J., SIKES, E., CARTER, L., WILMSHURST, J. M., LOWE, D. J., MCGLONE, M. S. \& SANDIFORD, A. 2012. Does the bipolar seesaw extend to the terrestrial southern mid-latitudes? Quaternary Science Reviews, 36, 214222.

NIBOUREL, L., HERMAN, F., COX, S. C., BEYSSAC, O. \& LAVÉ, J. 2015. Provenance analysis using Raman spectroscopy of carbonaceous material: A case study in the Southern Alps of New Zealand. Journal of Geophysical Research: Earth Surface, 120, 2056-2079.

NORRIS, R. J. \& COOPER, A. F. 2001. Late Quaternary slip rates and slip partitioning on the Alpine Fault, New Zealand. Journal of Structural Geology, 23, 507-520.

OERLEMANS, J. 1994. Quantifying global warming from the retreat of glaciers. ScienceAAAS-Weekly Paper Edition-including Guide to Scientific Information, 264, 243-244.

OERLEMANS, J. 1997. Climate sensitivity of Franz Josef Glacier, New Zealand, as revealed by numerical modeling. Arctic and Alpine Research, 233-239. 
PELEJERO, C., CALVO, E., BARROWS, T., LOGAN, G. A. \& DE DECKKER, P. 2006. South Tasman Sea alkenone palaeothermometry over the last four glacial/interglacial cycles. Marine Geology, 230, 73-86.

POWELL, R. D. 1990. Glacimarine processes at grounding-line fans and their growth to icecontact deltas. Geological Society, London, Special Publications, 53, 53-73.

QUINCEY, D., RICHARDSON, S., LUCKMAN, A., LUCAS, R. M., REYNOLDS, J., HAMBREY, M. \& GLASSER, N. 2007. Early recognition of glacial lake hazards in the Himalaya using remote sensing datasets. Global and Planetary Change, 56, 137-152.

RAMSEY, C. B. 2008. Deposition models for chronological records. Quaternary Science Reviews, 27, 42-60.

RAMSEY, C. B. \& LEE, S. 2013. Recent and planned developments of the program OxCal. Radiocarbon, 55, 720-730.

RATTENBURY, M. S. \& ISAAC, M. J. 2012. The QMAP 1:250 000 Geological Map of New Zealand project. New Zealand Journal of Geology and Geophysics, 55, 393-405.

REITMAN, N. G., BENNETT, S. E., GOLD, R. D., BRIGGS, R. W. \& DUROSS, C. B. 2015. High-resolution trench photomosaics from image-based modeling: Workflow and error analysis. Bulletin of the Seismological Society of America.

ROOP, H. A., DUNBAR, G. B., LEVY, R., VANDERGOES, M. J., FORREST, A. L., WALKER, S. L., PURDIE, J., UPTON, P. \& WHINNEY, J. 2015. Seasonal controls on sediment transport and deposition in Lake Ohau, South Island, New Zealand: Implications for a high-resolution Holocene palaeoclimate reconstruction. Sedimentology, 62, 826-844.

RYAN, M. T. 2017. Late Quaternary vegetation and climate history reconstructed from palynology of marine cores off southwestern New Zealand.

SAKAI, A. 2012. Glacial lakes in the Himalayas: a review on formation and expansion processes. Global Environmental Research, 16, 23-30.

SAKAI, A. \& FUJITA, K. 2010. Formation conditions of supraglacial lakes on debris-covered glaciers in the Himalaya. Journal of Glaciology, 56, 177-181.

SHULMEISTER, J., GOODWIN, I., RENWICK, J., HARLE, K., ARMAND, L., MCGLONE, M., COOK, E., DODSON, J., HESSE, P. \& MAYEWSKI, P. 2004. The Southern Hemisphere westerlies in the Australasian sector over the last glacial cycle: a synthesis. Quaternary International, 118, 23-53.

STUART, S. 2009. Influence of synoptic climate upon near-surface temperature lapse rates in the region of Franz Joseph Glacier and Aoraki Mount Cook. University of Wellington. Grad. Dip. Sc.

STUART, S. J. 2011. Observations and modelling of precipitation in the Southern Alps of New Zealand.

SUGGATE, R. P. 1990. Late pliocene and quaternary glaciations of New Zealand. Quaternary Science Reviews, 9, 175-197.

SUGGATE, R. P. \& ALMOND, P. C. 2005. The Last Glacial Maximum (LGM) in western South Island, New Zealand: implications for the global LGM and MIS 2. Quaternary Science Reviews, 24, 1923-1940.

SUGGATE, R. P., FLEMING, C. A., HARRIS, W. F. \& HORNIBROOK, N. D. 1968. The Paringa Formation Westland, New Zealand. New Zealand Journal of Geology and Geophysics, 11, 345-355.

SUTHERLAND, R. 1996. Transpressional development of the Australia-Pacific boundary through southern South Island, New Zealand: Constraints from Miocene-Pliocene sediments, Waiho-1 borehole, South Westland. New Zealand journal of geology and geophysics, 39, 251-264.

SUTHERLAND, R. 1999. Cenozoic bending of New Zealand basement terranes and Alpine Fault displacement: a brief review. New Zealand Journal of Geology and Geophysics, 42, 295-301.

SUTHERLAND, R., KIM, K., ZONDERVAN, A. \& MCSAVENEY, M. 2007. Orbital forcing of mid-latitude Southern Hemisphere glaciation since 100 ka inferred from cosmogenic 
nuclide ages of moraine boulders from the Cascade Plateau, southwest New Zealand. Geological Society of America Bulletin, 119, 443-451.

SUTHERLAND, R., TOWNEND, J., TOY, V., ALLEN, M., BARATIN, L., BARTH, N., BEACROFT., BENSON, L., BOESE, C., BOLES, A., BOULTON, C., CAPOVA, L., CARPENTER, B., CELERIER, B., CHAMBERLAIN, C., CONZE, R., COOPER, A., COUSSENS, J., COUTTS, A., COX, S., CRAW, L., DOAN, M., ECCLES, J., FAULKNER, D., GRIEVE, J., GROCHOWSKI, J., GULLEY, A., HENRY, G., HOWARTH, J., JACOBS, K., JEPPSON, T., KATO, N., KEYS, S., KIRILOVA, M., KOMETANI, Y., KOVACS, A., LANGRIDGE, R. \& LIN, W., LITTLE, T., MALLYON, D., MARIANI, B., MARX, R., MASSIOT, C., MATHEWSON, L., MELOSH, B., MENZIES, C., MOORE, J., MORALES, L., MORGAN, C., MORI, H., NIEMEIJERA, A., NISHIKAWA, O., NITSCH, O., PARIS CAVAILHÈS, J., POOLEY, B., PRIOR, D., PYNE, AL., SAUER, K., SAVAGE, M., SCHLEICHER, A., SCHMITT, D., SHIGEMATSU, N., TAYLOR-OFFORD, S., TOBIN, H., UPTON, P., VALDEZ, R., WEAVER, K., WIERSBERG, T., WILLIAMS J., YEO, S., ZIMMER, M 2015. Deep Fault Driling Project (DFDP), Alpine Fault Boreholes DFDP-2A and DFDP-2B Technical Completion Report,. GNS Science Report.

THACKRAY, G. D., SHULMEISTER, J. \& FINK, D. 2009. Evidence for expanded Middle and Late Pleistocene glacier extent in northwest Nelson, New Zealand. Geografiska Annaler: Series A, Physical Geography, 91, 291-311.

TURNBULL, I. M., MORTIMER, N. \& CRAW, D. 2001. Textural zones in the Haast Schista reappraisal. New Zealand Journal of Geology and Geophysics, 44, 171-183.

VANDERGOES, M. J. \& FITZSIMONS, S. J. 2003. The Last Glacial-Interglacial Transition (LGIT) in south Westland, New Zealand: paleoecological insight into mid-latitude Southern Hemisphere climate change. Quaternary Science Reviews, 22, 1461-1476.

VANDERGOES, M. J., NEWNHAM, R. M., DENTON, G. H., BLAAUW, M. \& BARRELL, D. J. A. 2013. The anatomy of Last Glacial Maximum climate variations in south Westland, New Zealand, derived from pollen records. Quaternary Science Reviews, 74, 215-229.

VRY, J., BAKER, J., MAAS, R., LITTLE, T., GRAPES, R. \& DIXON, M. 2004. Zoned (Cretaceous and Cenozoic) garnet and the timing of high grade metamorphism, Southern Alps, New Zealand. Journal of Metamorphic Geology, 22, 137-157.

WALLACE, L. M., BEAVAN, J., MCCAFFREY, R., BERRYMAN, K. \& DENYS, P. 2007. Balancing the plate motion budget in the South Island, New Zealand using GPS, geological and seismological data. Geophysical Journal International, 168, 332-352.

WARREN, C. R. 1991. Terminal environment, topographic control and fluctuations of West Greenland glaciers. Boreas, 20, 1-15.

WEAVER, P. P., CARTER, L. \& NEIL, H. L. 1998. Response of surface water masses and circulation to late Quaternary climate change east of New Zealand. Paleoceanography, $13,70-83$.

WELLMAN, H., GRINDLEY, G. \& MUNDEN, F. The Alpine schists and the upper Triassic of Harpers Pass (Sheet S52), South Island, New Zealand. Transactions of the Royal Society of New Zealand, 1952. 213-227.

WELTJE, G. J. \& VON EYNATTEN, H. 2004. Quantitative provenance analysis of sediments: review and outlook. Sedimentary Geology, 171, 1-11.

WHITEHOUSE, I. 1986. Geomorphology of a compressional plate boundary, Southern Alps, New Zealand. International geomorphology, 897-924.

WHITTAKER, T. E., HENDY, C. H. \& HELLSTROM, J. C. 2011. Abrupt millennial-scale changes in intensity of Southern Hemisphere westerly winds during marine isotope stages 2-4. Geology, 39, 455-458.

WOODWARD, C. A. \& SHULMEISTER, J. 2007. Chironomid-based reconstructions of summer air temperature from lake deposits in Lyndon Stream, New Zealand spanning the MIS 3/2 transition. Quaternary Science Reviews, 26, 142-154. 


\section{Appendix A}

A1): Raw ${ }^{14} \mathrm{C}$ ages for samples submitted from DFDP-2 drilling. Samples submitted by Dr Simon Cox and Dr Jamie Howarth.

\begin{tabular}{|ccccc|}
\hline $\begin{array}{c}\text { Sample Depth } \\
\text { (metres MD) }\end{array}$ & Sample Description & Rafter ID & CRA (yBP) & CRA error \\
\hline DFDP-2B 19.9-20 & Large wood fragment & $40706 / 6$ & 678 & 22 \\
DFDP-2A 59 & Large wood fragment & $40706 / 3$ & 13380 & 56 \\
DFDP-2A 84 & Large plant fragment & $40706 / 4$ & 13319 & 57 \\
DFDP-2A 129.3 & Plant fragment & $40706 / 5$ & 13480 & 57 \\
DFDP-2B 228-233 & Wood fragment & $40876 / 2$ & 13873 & 68 \\
\hline
\end{tabular}

A2): Location of samples collected and utilised in this thesis:

\begin{tabular}{|c|c|c|c|c|c|}
\hline Sample Location & Station name & Coordinates (NZGD) & Sample name & Sample type & Notes \\
\hline Whataroa River & $\begin{array}{c}\text { Borehole DFDP- } \\
2 \mathrm{~A}\end{array}$ & $\begin{array}{l}\text { E: } 1389611.5 \\
\text { N:5203642.6 }\end{array}$ & DFDP-2A & Drilling samples & $\mathrm{N} / \mathrm{A}$ \\
\hline Whataroa River & $\begin{array}{c}\text { Borehole DFDP- } \\
\text { 2B }\end{array}$ & $\begin{array}{l}\text { E: } 1389599.2 \\
N: 5203641.9\end{array}$ & DFDP-2B & Drilling samples & $\mathrm{N} / \mathrm{A}$ \\
\hline $\begin{array}{l}\text { Waitangitaona } \\
\text { River }\end{array}$ & Waitan-6 & $\begin{array}{l}\text { E:1381277 } \\
N: 5202894\end{array}$ & 6Waitan Bulk & Bulk sample & $\begin{array}{c}\text { Bulk sample of laminated } \\
\text { silstone unit }\end{array}$ \\
\hline $\begin{array}{c}\text { Waitangitaona } \\
\text { River }\end{array}$ & Waitan-6 & $\begin{array}{l}E: 1381277 \\
N: 5202894\end{array}$ & $6 \mathrm{WBC} 1-4$ & $\begin{array}{c}\text { Samples through } \\
\text { individual bed }\end{array}$ & $\begin{array}{l}\text { Taken at } 1 \mathrm{~cm} \text { intervals } \\
\text { through graded bed }\end{array}$ \\
\hline $\begin{array}{c}\text { Waitangitaona } \\
\text { River }\end{array}$ & Waitan-6 & $\begin{array}{l}E: 1381277 \\
N: 5202895\end{array}$ & 6Waitan Clasts & Lonestone clasts & $\begin{array}{c}\text { Collected through visible } \\
\text { outcrop }\end{array}$ \\
\hline $\begin{array}{l}\text { Waitangitaona } \\
\text { River }\end{array}$ & Waitan-9 & $\begin{array}{l}E: 1381554 \\
N: 5201512\end{array}$ & $\begin{array}{c}\text { Upper cont, Mid- } \\
\text { Section, Section Base }\end{array}$ & Bulk samples & $\begin{array}{c}\text { Taken at } \sim 1.5 \text { metre } \\
\text { intervals through section }\end{array}$ \\
\hline $\begin{array}{c}\text { Waitangitaona } \\
\text { River } \\
\end{array}$ & Waitan-12 & $\begin{array}{l}\text { E:1381475 } \\
\text { N:5201357 }\end{array}$ & Waitan-12 Bulk & Bulk sample & $\begin{array}{c}\text { Collected } 1 \text { metre above } \\
\text { outcrop base }\end{array}$ \\
\hline Arahura River & Arahura Bridge & $\begin{array}{l}E: 1455829 \\
N: 5256717\end{array}$ & Arah100, Arah200 & Bulk sample & $\begin{array}{l}\text { Collected at } 100 \text { metre } \\
\text { intervals along strike }\end{array}$ \\
\hline Arahura River & Cesspool & $\begin{array}{l}\text { E: } 1456186 \\
N: 5253885\end{array}$ & Sandy silstone unit & Bulk sample & $\begin{array}{l}\text { Bulk sample of sandy } \\
\text { siltstone unit }\end{array}$ \\
\hline Arahura River & Cesspool & $\begin{array}{l}\text { E: } 1456186 \\
N: 5253872\end{array}$ & Conglomerate unit & Bulk sample & $\begin{array}{c}\text { Bulk sample of } \\
\text { conglomerate unit }\end{array}$ \\
\hline Waiho River & Waiho Susp & $\begin{array}{l}E: 1371163 \\
N: 5189258\end{array}$ & Waiho Susp Load & $\begin{array}{c}\text { River suspended } \\
\text { load }\end{array}$ & $\begin{array}{l}\text { Collected along with } \\
\text { fluid }\end{array}$ \\
\hline
\end{tabular}

\section{A3): Summary clast shape analyses.}

\begin{tabular}{|c|c|c|c|c|c|c|c|c|c|}
\hline Sample Name & $\begin{array}{c}\text { Clasts } \\
\text { analysed }\end{array}$ & $\begin{array}{c}\text { Mean A } \\
\text { axes (mm) }\end{array}$ & $\begin{array}{c}\text { Mean B } \\
\text { axes (mm) }\end{array}$ & $\begin{array}{c}\text { Mean C } \\
\text { axes (mm) }\end{array}$ & $\begin{array}{c}\text { Mean } \\
\text { roundness }\end{array}$ & \%Schist & $\begin{array}{c}\text { \%Semi- } \\
\text { schist }\end{array}$ & $\begin{array}{c}\text { \%Sandstone/ } \\
\text { Argillite }\end{array}$ & \%Other \\
\hline Waitan-6 & 10 & 67.9 & 44.9 & 18 & 0.18 & 0 & 0 & 100 & 0 \\
\hline Waitan-12 & 40 & 32.6 & 23.1 & 14.7 & 0.51 & 90 & 4 & 0 & 0 \\
\hline Cesspool & 47 & 31.2 & 20.9 & 11.1 & 0.53 & 49 & 40 & 11 & 0 \\
\hline Arah 100 & 50 & 37.5 & 25.7 & 13.5 & 0.47 & 62 & 34 & 2 & 2 \\
\hline Arah 200 & 50 & 34.8 & 23.5 & 13.1 & 0.5 & 52 & 36 & 8 & 2 \\
\hline
\end{tabular}


A4): Mean, median, modal grain-size and standard deviation for samples used in

Section logs and grain-size histograms. Full grain-size profiles for samples displayed as histograms are available in Digital Appendix B.

\begin{tabular}{|c|c|c|c|c|c|c|c|c|c|}
\hline $\begin{array}{c}\text { Sample Depth } \\
\text { (metres MD) }\end{array}$ & $\begin{array}{l}\text { Mean Grain- } \\
\text { size }(\mu \mathrm{m})\end{array}$ & $\begin{array}{l}\text { Median } \\
\text { Grain-size } \\
(\mu \mathrm{m})\end{array}$ & $\begin{array}{c}\text { Modal } \\
\text { Grain-size } \\
(\mu \mathrm{m})\end{array}$ & $\begin{array}{c}\text { Standard } \\
\text { Deviation } \\
(\mu \mathrm{m})\end{array}$ & $\begin{array}{c}\text { Sample Depth } \\
\text { (metres MD) }\end{array}$ & $\begin{array}{c}\text { Mean } \\
\text { Grain-size } \\
(\mu \mathrm{m})\end{array}$ & $\begin{array}{c}\text { Median } \\
\text { Grain-size } \\
(\mu \mathrm{m})\end{array}$ & $\begin{array}{c}\text { Modal } \\
\text { Grain-size } \\
(\mu \mathrm{m})\end{array}$ & $\begin{array}{c}\text { Standard } \\
\text { Deviation } \\
(\mu \mathrm{m})\end{array}$ \\
\hline \multicolumn{10}{|l|}{ DFDP-2A } \\
\hline 2 & 344.8 & 268.3 & 568 & 326.7 & 132.42 & 26.93 & 22.46 & 34.6 & 19.87 \\
\hline 5 & 196.4 & 50.91 & 16.4 & 287.1 & 132.46 & 14.08 & 10.8 & 14.9 & 11.54 \\
\hline 8 & 246.5 & 107.3 & 517 & 322.7 & 132.89 & 22.23 & 16.16 & 16.4 & 18.98 \\
\hline 10 & 331.7 & 163 & 684 & 362.3 & 134 & 17.62 & 13.49 & N/A & 14.27 \\
\hline 11 & 346.8 & 221.5 & 623 & 352.6 & 135.55 & 20.4 & 14.46 & $\mathrm{~N} / \mathrm{A}$ & 19.99 \\
\hline 12 & 170.5 & 44.32 & 16.4 & 273.4 & 138.55 & 15.48 & 12.35 & $\mathrm{~N} / \mathrm{A}$ & 11.22 \\
\hline 15 & 156.3 & 47.78 & 16.4 & 231.6 & 141.55 & 19.86 & 14.62 & 16.4 & 17.54 \\
\hline 20 & 238.6 & 60.09 & 38 & 350 & 142.98 & 18.11 & 14.09 & 16.4 & 14.29 \\
\hline 25 & 349.6 & 248.5 & 517 & 318.9 & 143.83 & 29.08 & 22.79 & 38 & 23.64 \\
\hline 28 & 158.3 & 37.4 & 16.4 & 279.1 & 144.05 & 20.05 & 14.62 & 16.4 & 18.32 \\
\hline 30 & 320 & 132.5 & 751 & 370.2 & 144.33 & 12.35 & 7.761 & 6.45 & 13.25 \\
\hline 35 & 612.1 & 597.3 & 751 & 383 & 145.64 & 7.074 & 4.542 & 3.36 & 10.05 \\
\hline 40 & 406.2 & 279.5 & 623 & 364 & 145.68 & 9.149 & 7.313 & 6.45 & 6.323 \\
\hline 45 & 439.2 & 383.9 & 623 & 329.5 & 148.6 & 12.69 & 11.19 & 12.4 & 7.076 \\
\hline 49 & 257.6 & 176.7 & 203 & 254.5 & 149.1 & 11.77 & 10.09 & 10.3 & 6.882 \\
\hline 50 & 383.6 & 272.2 & 623 & 356.1 & 149.95 & 45.51 & 42.47 & 60 & 31.49 \\
\hline 55 & 278.2 & 100.1 & 751 & 342 & 150.56 & 47.67 & 44.47 & 55.1 & 32.13 \\
\hline 60 & 200.2 & 98.17 & 140 & 292.4 & 151.08 & 50.77 & 46.45 & 55.1 & 35.83 \\
\hline 65 & 62.75 & 43.51 & 96.5 & 56.64 & 154.65 & 25.76 & 19.73 & 38 & 20.64 \\
\hline 70 & 56.47 & 41.37 & 45.8 & 48.76 & 154.92 & 14.57 & 11.75 & 12.4 & 10.71 \\
\hline 75 & 68.47 & 64.76 & 96.5 & 47.52 & 155.34 & 17.48 & 14.33 & 16.4 & 12.72 \\
\hline 80 & 40.06 & 33.7 & 45.8 & 29.58 & 155.37 & 9.672 & 7.003 & 6.45 & 8.64 \\
\hline 85 & 32.19 & 25.97 & 41.7 & 25.25 & 156.15 & 15.12 & 13.17 & 14.9 & 9.537 \\
\hline 90 & 27.4 & 21.95 & 38 & 21.31 & 157.32 & 13.86 & 9.516 & 10.3 & 13.3 \\
\hline 95 & 25.43 & 19.79 & 34.6 & 20.55 & 157.33 & 14.09 & 9.507 & 8.54 & 13.83 \\
\hline 100 & 25.33 & 20.53 & 34.6 & 17.98 & DFDP-2B & & & & \\
\hline 105 & 22.63 & 18.05 & 18 & 16.48 & 159 & 21.39 & 15.17 & N/A & 19.48 \\
\hline 110 & 27.9 & 21.16 & 34.6 & 22.28 & 165 & 23 & 15.65 & $\mathrm{~N} / \mathrm{A}$ & 24.35 \\
\hline 115 & 22.03 & 16.76 & 18 & 17.52 & 171 & 21.06 & 14.57 & $\mathrm{~N} / \mathrm{A}$ & 21.26 \\
\hline 120 & 22.01 & 15.71 & 16.4 & 20.66 & 177 & 25.61 & 17 & $\mathrm{~N} / \mathrm{A}$ & 28.52 \\
\hline 125 & 20.62 & 15.07 & 19.8 & 18.74 & 198.55 & 15.18 & 11.01 & N/A & 13.32 \\
\hline 127.84 & 22.84 & 17.5 & 18 & 17.86 & 202 & 20.29 & 14.19 & N/A & 22.56 \\
\hline 128.44 & 14.75 & 11 & 14.9 & 12.66 & 204.5 & 12.01 & 9.79 & $\mathrm{~N} / \mathrm{A}$ & 7.92 \\
\hline 129.46 & 19.14 & 15.02 & 18 & 14.79 & 212.1 & 9.22 & 7.315 & N/A & 6.437 \\
\hline 130.94 & 26.85 & 20.24 & 18 & 22.94 & 213 & 12.8 & 10.07 & $\mathrm{~N} / \mathrm{A}$ & 9.674 \\
\hline 130.95 & 13.46 & 10.71 & 12.4 & 10.14 & 218.75 & 16.36 & 13.42 & N/A & 11.81 \\
\hline 130.96 & 15.59 & 12.39 & 14.9 & 11.79 & 218.8 & 14.23 & 11.28 & N/A & 10.66 \\
\hline 130.97 & 16.83 & 13.41 & 16.4 & 12.61 & 222.8 & 13.65 & 11.43 & $\mathrm{~N} / \mathrm{A}$ & 8.48 \\
\hline 130.98 & 26.48 & 20.9 & 34.6 & 20.37 & 229 & 20.28 & 17.09 & $\mathrm{~N} / \mathrm{A}$ & 13.58 \\
\hline 132.09 & 26.39 & 16.36 & 18 & 31.78 & 232 & 12.28 & 9.847 & N/A & 9.705 \\
\hline
\end{tabular}


A5): Summary sieve-stack grain-size data collected from DFDP-2A, 0-59 metres MD.

\begin{tabular}{|c|c|c|c|c|c|c|c|}
\hline $\begin{array}{l}\text { Sample Depth } \\
\text { (metres MD) }\end{array}$ & $>2 \mathrm{~mm}$ & $\begin{array}{c}2-0.85 \\
\mathrm{~mm}\end{array}$ & $<0.85 \mathrm{~mm}$ & $\begin{array}{l}\text { Sample Depth } \\
\text { (metres MD) }\end{array}$ & $>2 \mathrm{~mm}$ & $\begin{array}{c}2-0.85 \\
\mathrm{~mm}\end{array}$ & $<0.85 \mathrm{~mm}$ \\
\hline DFDP-2A & & & & DFDP-2A & & & \\
\hline 2 & $6 \%$ & $30 \%$ & $64 \%$ & 31 & $81 \%$ & $8 \%$ & $11 \%$ \\
\hline 3 & $6 \%$ & $28 \%$ & $66 \%$ & 32 & $82 \%$ & $8 \%$ & $10 \%$ \\
\hline 4 & $10 \%$ & $15 \%$ & $74 \%$ & 33 & $53 \%$ & $16 \%$ & $30 \%$ \\
\hline 5 & $28 \%$ & $16 \%$ & $56 \%$ & 34 & $62 \%$ & $13 \%$ & $25 \%$ \\
\hline 6 & $46 \%$ & $15 \%$ & $39 \%$ & 35 & $68 \%$ & $10 \%$ & $22 \%$ \\
\hline 7 & $36 \%$ & $36 \%$ & $28 \%$ & 36 & $78 \%$ & $8 \%$ & $14 \%$ \\
\hline 8 & $8 \%$ & $28 \%$ & $64 \%$ & 37 & $59 \%$ & $13 \%$ & $27 \%$ \\
\hline 9 & $59 \%$ & $25 \%$ & $16 \%$ & 38 & $85 \%$ & $5 \%$ & $10 \%$ \\
\hline 10 & $64 \%$ & $22 \%$ & $13 \%$ & 39 & $82 \%$ & $7 \%$ & $11 \%$ \\
\hline 11 & $38 \%$ & $29 \%$ & $33 \%$ & 40 & $70 \%$ & $9 \%$ & $21 \%$ \\
\hline 12 & $93 \%$ & $3 \%$ & $4 \%$ & 41 & $71 \%$ & $12 \%$ & $17 \%$ \\
\hline 13 & $84 \%$ & $8 \%$ & $8 \%$ & 42 & $80 \%$ & $8 \%$ & $12 \%$ \\
\hline 14 & $82 \%$ & $8 \%$ & $11 \%$ & 43 & $87 \%$ & $5 \%$ & $8 \%$ \\
\hline 15 & $66 \%$ & $16 \%$ & $18 \%$ & 44 & $71 \%$ & $9 \%$ & $20 \%$ \\
\hline 16 & $76 \%$ & $12 \%$ & $13 \%$ & 45 & $46 \%$ & $18 \%$ & $37 \%$ \\
\hline 17 & $67 \%$ & $16 \%$ & $17 \%$ & 46 & $83 \%$ & $5 \%$ & $12 \%$ \\
\hline 18 & $65 \%$ & $14 \%$ & $21 \%$ & 47 & $56 \%$ & $17 \%$ & $27 \%$ \\
\hline 19 & $80 \%$ & $7 \%$ & $13 \%$ & 48 & $72 \%$ & $7 \%$ & $22 \%$ \\
\hline 20 & $89 \%$ & $6 \%$ & $5 \%$ & 49 & $79 \%$ & $4 \%$ & $16 \%$ \\
\hline 21 & $69 \%$ & $10 \%$ & $21 \%$ & 50 & $68 \%$ & $9 \%$ & $23 \%$ \\
\hline 22 & $71 \%$ & $10 \%$ & $18 \%$ & 51 & $64 \%$ & $13 \%$ & $23 \%$ \\
\hline 23 & $71 \%$ & $8 \%$ & $21 \%$ & 52 & $88 \%$ & $5 \%$ & $7 \%$ \\
\hline 24 & $70 \%$ & $11 \%$ & $19 \%$ & 53 & $65 \%$ & $14 \%$ & $21 \%$ \\
\hline 25 & $58 \%$ & $9 \%$ & $34 \%$ & 54 & $48 \%$ & $17 \%$ & $35 \%$ \\
\hline 26 & $76 \%$ & $11 \%$ & $13 \%$ & 55 & $85 \%$ & $5 \%$ & $10 \%$ \\
\hline 27 & $83 \%$ & $6 \%$ & $11 \%$ & 56 & $64 \%$ & $17 \%$ & $19 \%$ \\
\hline 28 & $90 \%$ & $6 \%$ & $4 \%$ & 57 & $76 \%$ & $12 \%$ & $11 \%$ \\
\hline 29 & $72 \%$ & $11 \%$ & $16 \%$ & 58 & $56 \%$ & $22 \%$ & $22 \%$ \\
\hline 30 & $82 \%$ & $10 \%$ & $8 \%$ & 59 & $34 \%$ & $33 \%$ & $33 \%$ \\
\hline
\end{tabular}




\title{
Appendix B
}

\section{B1) Detrital sediment provenance using portable X-ray Fluorescence (pXRF)}

\begin{abstract}
Present methods of quantifying the provenance of sediments derived from Westland catchments are limited, being time consuming and requiring specialist equipment. A bulk chemical provenance proxy, obtainable using pXRF methods would present a significant advancement in this field. To evaluate this, sediment samples from South Westland were analysed via pXRF, generating comprehensive bulk chemistry datasets. Provenance of sediments was determined from published data using Raman Spectroscopy of carbonaceous material held in sediment grains. This allowed the provenance of sediment samples to be determined, and expressed as the percentage of grains derived from schist, semi-schist or sandstone bedrock. Major and minor element concentrations, as well as element ratios were then interrogated for samples with a known provenance. Bedrock XRF datasets showed a relationship between rock type (schist, semi-schist, sandstone) and enrichment/depletion in $\mathrm{Sr} / \mathrm{CaO}$ ratios. Despite this, no clear relationship was observed between detrital sediment provenance and $\mathrm{Sr} / \mathrm{CaO}$ ratio. A moderately strong relationship between detrital sediment provenance and $\mathrm{Fe} / \mathrm{Ca}$ ratio was observed, though sample grain-size also shows a strong relationship with $\mathrm{Fe} / \mathrm{Ca}$ ratio. In both cases, this study is limited by a lack of sediment provenance datasets.
\end{abstract}

\section{Provenance studies using Westland sediments}

The Whataroa catchment drains bedrock of variable metamorphic grade, from amphibolite grade schist proximal to the Alpine Fault, to prehnite-pumpellyite grade meta-sedimentary rocks proximal to the main divide (Cox and Barrell, 2007). This metamorphic gradient leads to spatial variance in bedrock peak metamorphic 
temperature, index mineral assemblages, and minor changes in bulk rock chemistry. Due to this spatial variability, the Whataroa catchment is ideal for studies of sediment provenance, which can be used to evaluate spatial variance in catchment erosion, sediment supply and sediment transfer (Nibourel et al., 2015).

The provenance of pebble-boulder clasts can be determined through visual examination, as employed by Cox and Nibourel (2015) in evaluating the modern bed-load composition of Westland rivers. Additionally, analysis of heavy mineral assemblages in sediments could be used for provenance studies, as there are a number of metamorphic isograds marking reactions and changes in mineral assemblages with metamorphic grade (Cox and Barrell, 2007). This method is useful for producing qualitative datasets on sediment provenance, but is often regarded as unfavourable for quantitative work (Weltje and von Eynatten, 2004).

A developing field of research uses Raman Spectroscopy of carbonaceous material (RSCM) as a method of detrital provenance analysis, shown as effective in evaluating detrital sediment provenance in the Westland region (Nibourel et al., 2015, Herman et al., 2015). Briefly summarised, RSCM quantitatively determines the peak metamorphic temperature of organic material hosted in detrital grains, which can then be associated with a region of catchment bedrock with the same peak metamorphic temperature. In a sediment sample, 100-200 sediment grains are analysed, to develop peak metamorphic temperature histograms for each unique sediment sample. Histograms can then be compared between samples, to evaluate relative sediment inputs from different regions of the catchment (Nibourel et al., 2015 for a detailed review).

RSCM is a useful method of provenance analysis for Westland catchments where transitions of metamorphic grade in bedrock allow precise spatial determinations of sediment provenance. The RSCM method is time consuming however, requiring specialist training, equipment and calibrations to perform. A bulk chemistry provenance proxy would act to remove a number of the difficulties associated with the RSCM method.

\section{Premise for bulk chemistry to be utilised for provenance analysis}

To develop an effective proxy for sediment provenance using bulk chemical data, bulk chemical differences must be observed in catchment bedrock. To evaluate this, bulk 
chemical datasets of greenschist to oligoclase facies Alpine Schist, and prehnitepumpellyite grade sandstones were sourced.

Datasets were interrogated for major or minor element concentrations that showed systematic variations in chemistry related to lithology. Additionally, a number of element ratios were examined. This was done by producing a matrix of scatter plots, graphically displaying measured element concentrations against sample lithology.

While a number of element ratios showed minor variation with lithology, the statistically strongest relationship between lithology and chemistry was observed in $\mathrm{Sr} / \mathrm{CaO}$ ratio (Figure $\mathrm{A} 1$ ).

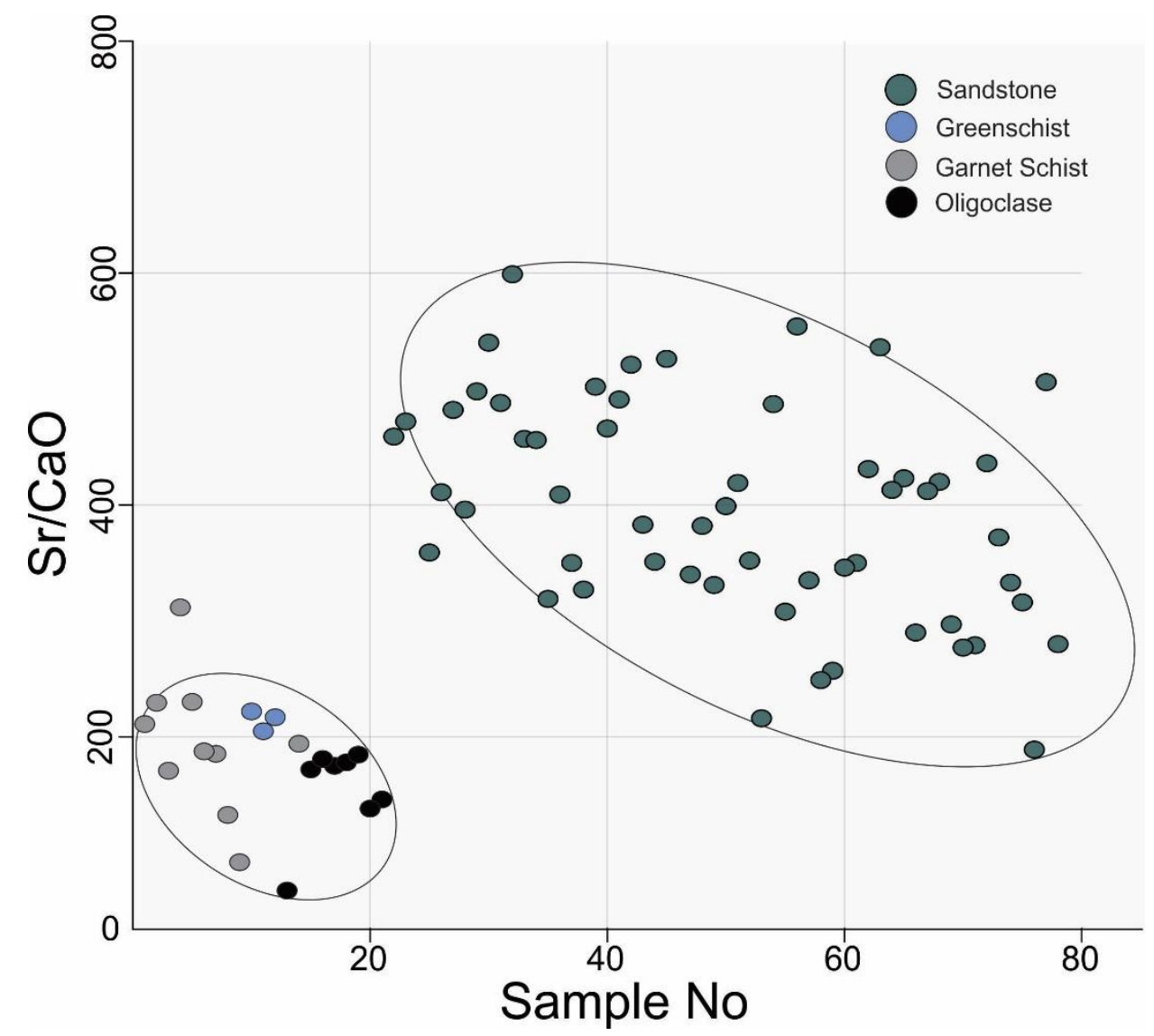

Figure $\mathrm{A} 1 \mathrm{Sr}(\mathrm{ppm}) / \mathrm{CaO}$ (wt\%) ratios of oligoclase, garnet and greenschists and prehnite-pumpellyite grade sandstones. Datasets supplied by Simon Cox from PETLAB and commercial datasets.

Prehnite-pumpellyite grade sandstones are observed to display higher $\mathrm{Sr} / \mathrm{CaO}$ ratios, with a sample mean of 403. Garnet, oligoclase and greenschist facies bedrock have considerably lower ratios, with a sample mean of 182. Should sediments eroded off sandstone and schist bedrock retain their bulk $\mathrm{Sr} / \mathrm{CaO}$ ratios, there is potential for the $\mathrm{Sr} / \mathrm{CaO}$ ratio in sediment samples to be a factor of sediment provenance. 


\section{Evaluating the use of $\mathrm{Sr} / \mathrm{CaO}$ ratio as a provenance proxy}

To determine the effectiveness of element ratios as a provenance proxy for sediments, ratios for sediment samples with a known provenance must be used. To do this, fluvial sediment samples analysed using the RSCM method of provenance analysis (Nibourel et al., 2015) were used as a training dataset.

Samples analysed by Nibourel et al. (2015) were collected from modern river sands, and sieved to solely retain the sand fraction prior to RSCM analysis. Using RSCM, a peak metamorphic temperature histogram was produced for each sample, corresponding to the percentage of the total sample derived from that bedrock temperature region (Figure A2).

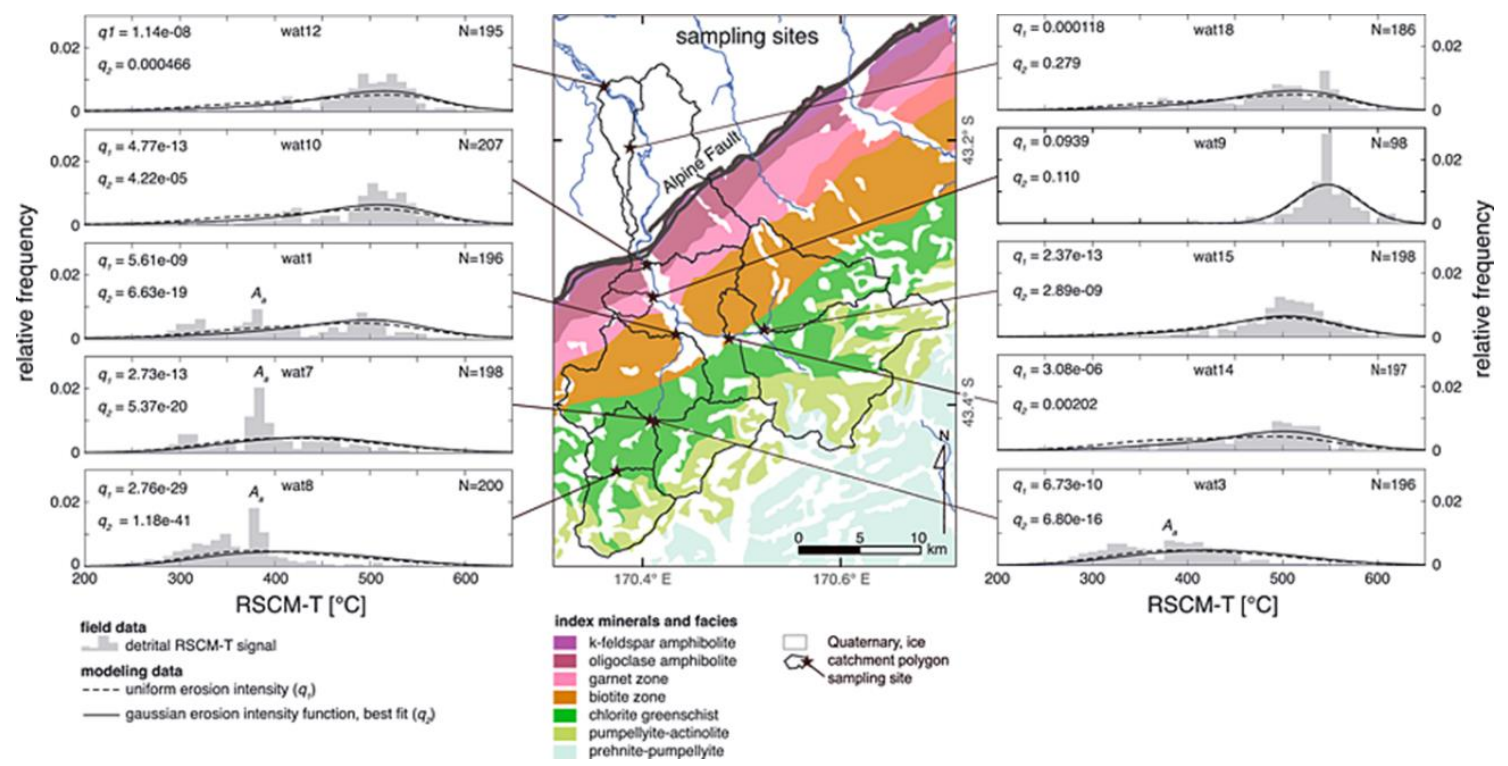

Figure A2 RSCM temperature analyses for 10 sediment samples (Wat1-Wat18) sampled in different regions of the Whataroa catchment (Figure published in Nibourel et al. (2015))

Using the temperature sub-divisions outlined by Nibourel et al. (2015), RSCM temperature histograms are divided into the percentage of sample derived from the schist, semi-schist and sandstone bedrock regions. Sediment grains with a peak metamorphic temperature of $>492{ }^{\circ} \mathrm{C}$ are classified as derived from schist bedrock (broadly corresponds to biotite in isograd). Sediments in the temperature range $>356{ }^{\circ} \mathrm{C}$ to $<492{ }^{\circ} \mathrm{C}$ are classified as semi-schist $\left(-356^{\circ} \mathrm{C}\right.$ corresponds to the chlorite in isograd). Samples with RSCM temperatures of $<356{ }^{\circ} \mathrm{C}$ are classified as prehnite-pumpellyite grade sandstone. 
In using the temperature divisions outlined, the 10 sediment histograms (Figure A2)

were expressed as percentage of sediment derived from schist, semi-schist and sandstone bedrock. Samples from side creeks draining high-grade schist (Wat9) were classified as $90-100 \%$ schist, whereas samples such as Wat 1 consist a mix of schist, semi-schist and sandstone components. The bedrock geology of the Whataroa catchment, divided into regions of schist, semi-schist and sandstone bedrock is displayed in Figure A3.

The sediment samples submitted for RSCM analysis by Nibourel et al. (2015) were then analysed via $\mathrm{pXRF}$ in this study. $\mathrm{pXRF}$ data was processed using the method outlined in

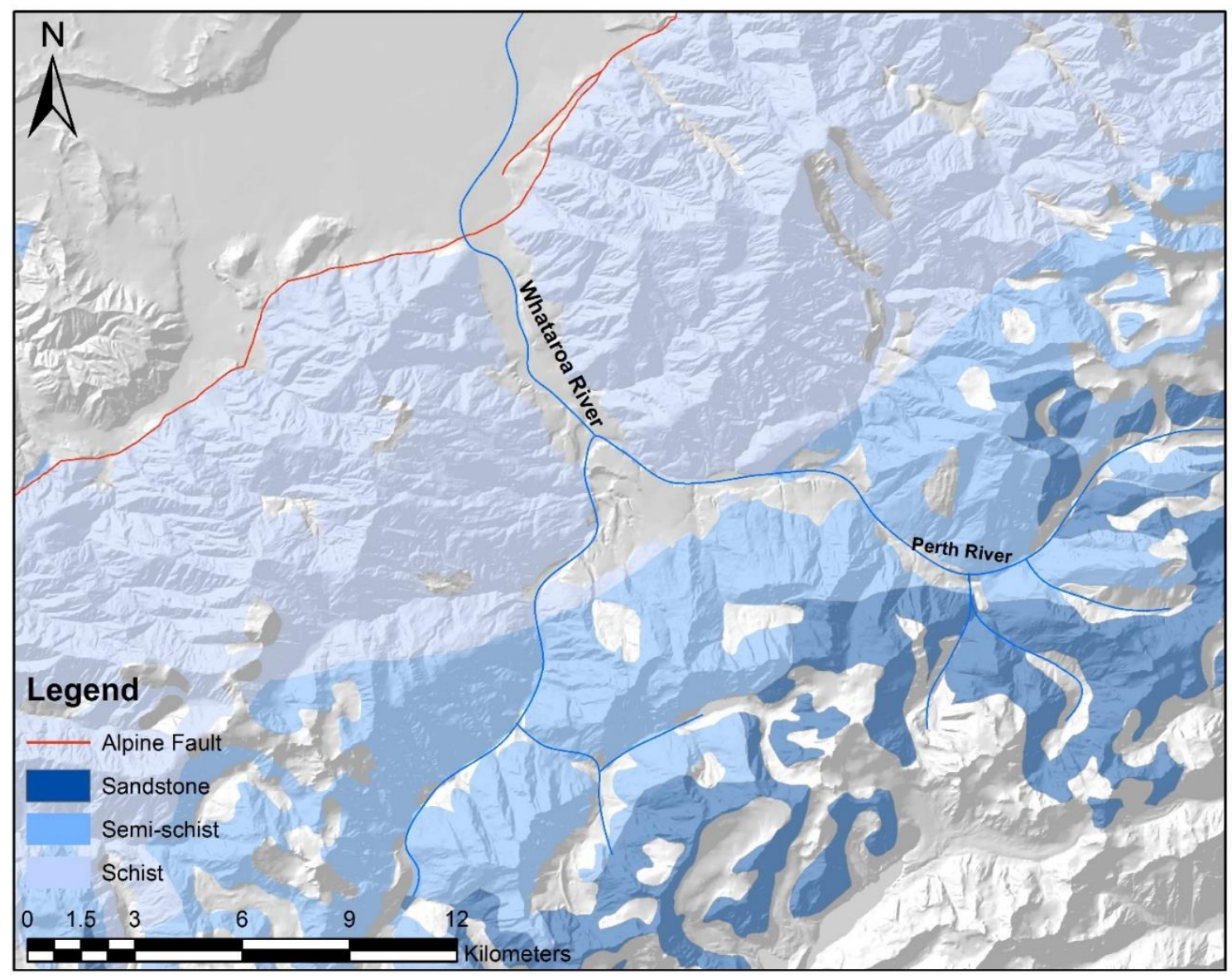

Figure A3 Simplified bedrock geology of the Whataroa catchment. Schist bedrock defined as biotite in isograd and higher grade, semi-schist defined as chlorite in isograd to biotite in isograd. Sandstone defined as lower grade than chlorite in isograd. Bedrock lithology mapped by Cox and Barrell (2007)

Section 2.3.2, to then be plotted against sample percentage schist, semi-schist and sandstone. Processed and unprocessed pXRF data used in this study is available in Digital Appendix C.

\section{$\mathrm{Sr} / \mathrm{CaO}$ provenance proxy}


Bedrock XRF data displayed clear variance between the $\mathrm{Sr} / \mathrm{CaO}$ ratios of schist and sandstone samples. Should this relationship extend to sediments eroded off such bedrock, samples with a high sandstone percentage (Wat3, Wat8) should display higher $\mathrm{Sr} / \mathrm{CaO}$ ratios. To evaluate this, sample percentage schist, semi-schist and sandstone were plotted against $\mathrm{Sr} / \mathrm{CaO}$ ratio (Figure $\mathrm{A} 4$ ).

From this analysis, no relationship between sediment provenance and $\mathrm{Sr} / \mathrm{CaO}$ ratio is observed. This shows that $\mathrm{Sr} / \mathrm{CaO}$ ratio in sediment samples is influenced by parameters other than sediment provenance.

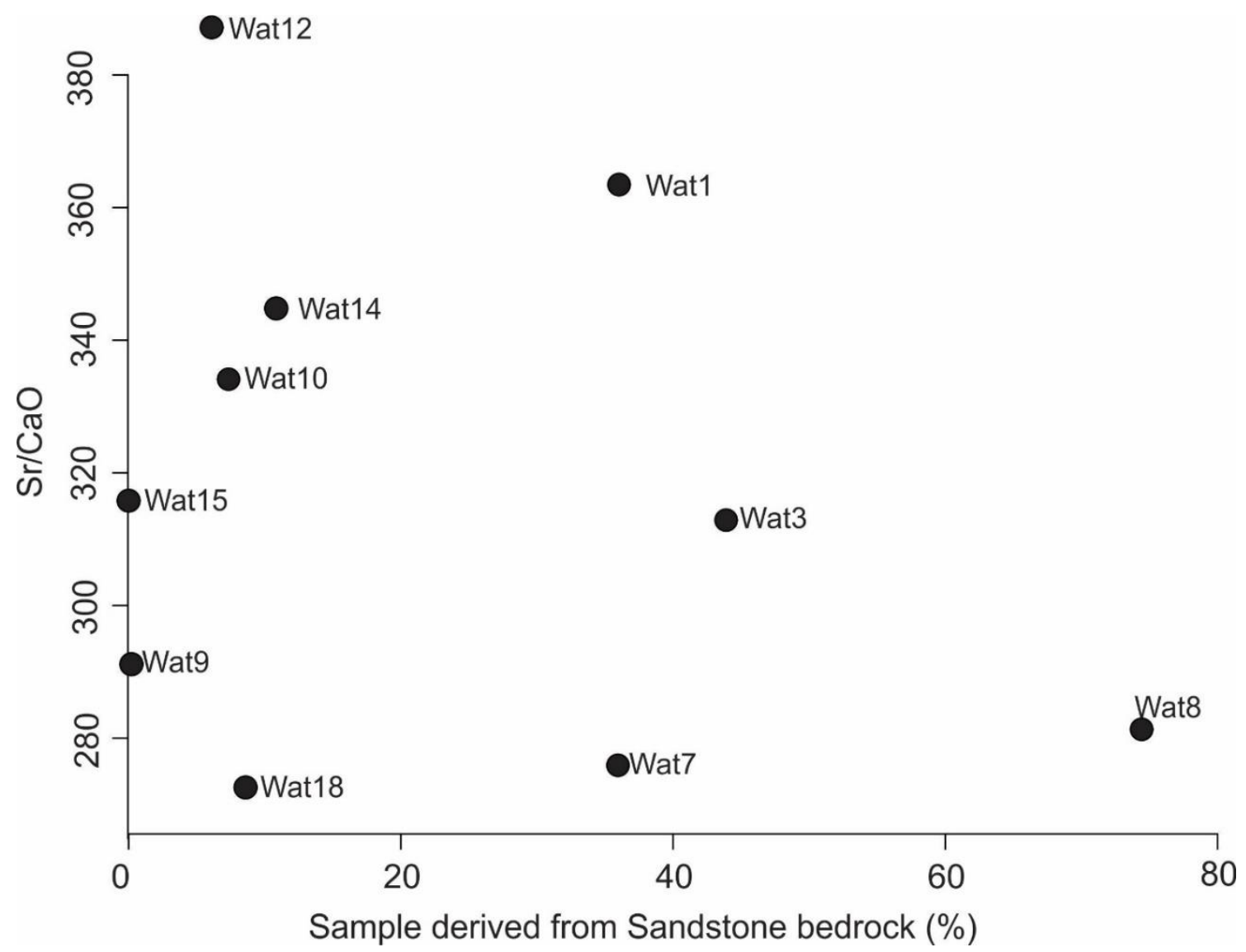

Figure $\mathrm{A} 4 \mathrm{Sr}$ (ppm)/CaO (wt\%) ratio for sediment samples analysed using RSCM by Nibourel et al. (2015), against sample percent sandstone calculated from RSCM temperature histograms

\section{Fe/Ca provenance proxy}

To evaluate additional relationships between sample chemistry and sediment provenance, scatterplot matrix diagrams were developed. This allowed ratios of all measured elements to be plotted against sediment provenance percentages. A relationship between sample percentage derived from schist bedrock and $\mathrm{Fe} / \mathrm{Ca}$ ratio was observed, where samples of higher percentage schist were observed to have higher $\mathrm{Fe} / \mathrm{Ca}$ ratios (Figure A5). An $\mathrm{R}^{2}$ of 0.614 suggests the majority of variance in the $\mathrm{Fe} / \mathrm{Ca}$ 
ratios can be explained by sample provenance, specifically the sample percentage derived from schist bedrock.

Despite this, no clear relationship between bedrock Fe/Ca ratio and sample lithology was observed. This finding suggests that the relationship between sample percentage schist and $\mathrm{Fe} / \mathrm{Ca}$ ratio may be related to factors other than bedrock chemistry.

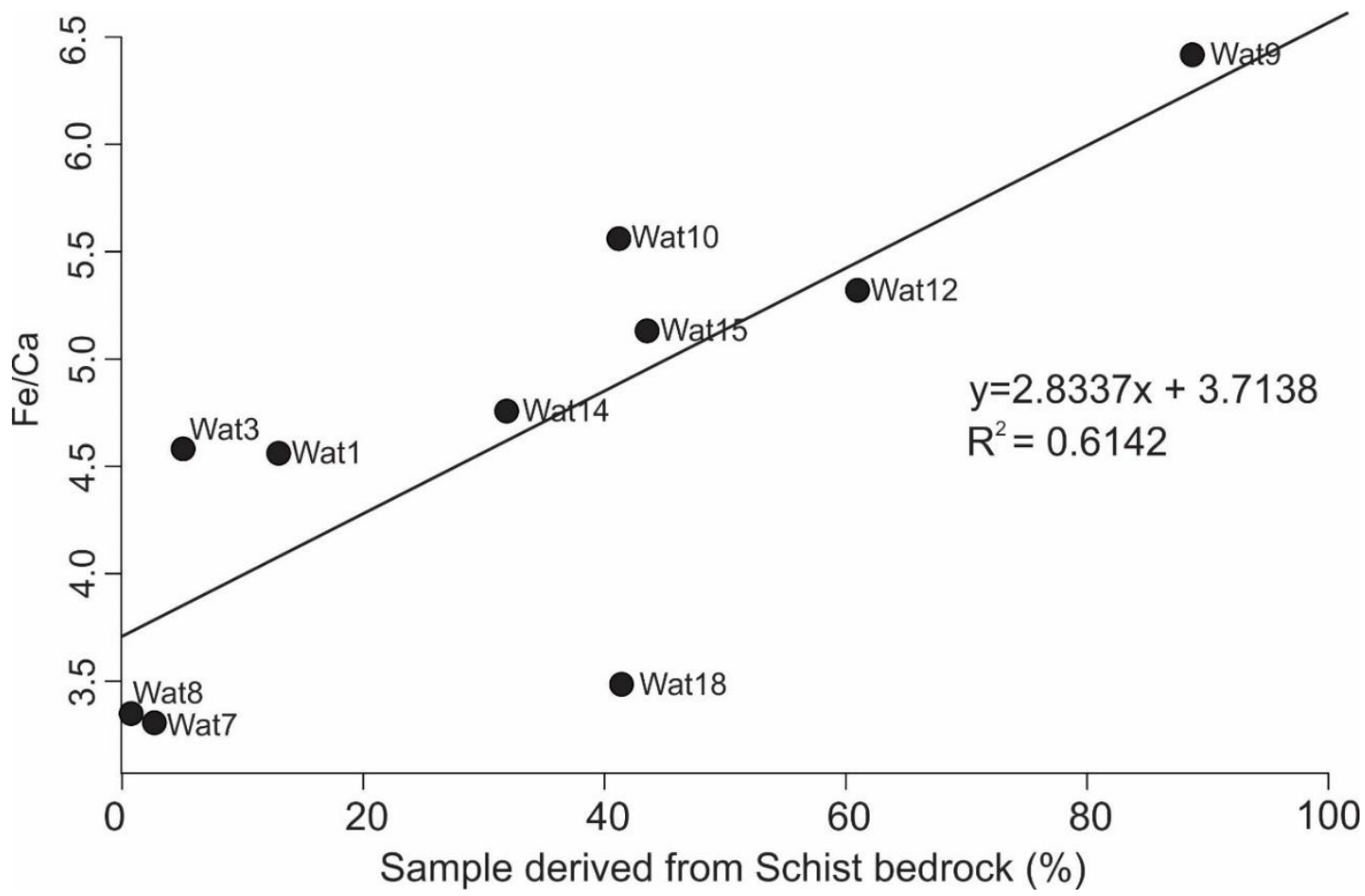

Figure A5 Fe/Ca (ppm) ratio for sediment samples analysed using RSCM by Nibourel et al. (2015), against sample percent Schist calculated from RSCM temperature histograms

\section{Additional factors influencing bulk chemistry of sediments}

In addition to the Wat1-Wat18 samples, all DFDP-2 sediment samples utilised for grain-size analysis were analysed via $\mathrm{pXRF}$. This generated a comprehensive dataset to examine the potential influence of sediment provenance on sample bulk chemistry.

Of all samples analysed, $\sim 37 \%$ display $\mathrm{Fe} / \mathrm{Ca}$ ratios that are $<3.5$ or $>6.5$, outside the possible range of values should provenance be the sole control on Fe/Ca ratio (Figure A5). This shows that another significant influence on sediment Fe/Ca ratio exists, argued to be sample grain-size.

In samples with a mean grain-size of less than $\sim 60 \mu \mathrm{m}, \mathrm{Fe} / \mathrm{Ca}$ ratios increases exponentially, with the finest grain-size samples $(\sim 7 \mu \mathrm{m})$ having ratios of $\sim 14$ (Figure 
A6). Samples with mean grain-sizes of $>60 \mu \mathrm{m}$ display $\mathrm{Fe} / \mathrm{Ca}$ display ratios that are comparable to those measured in the Wat1-Wat18 river sand samples.

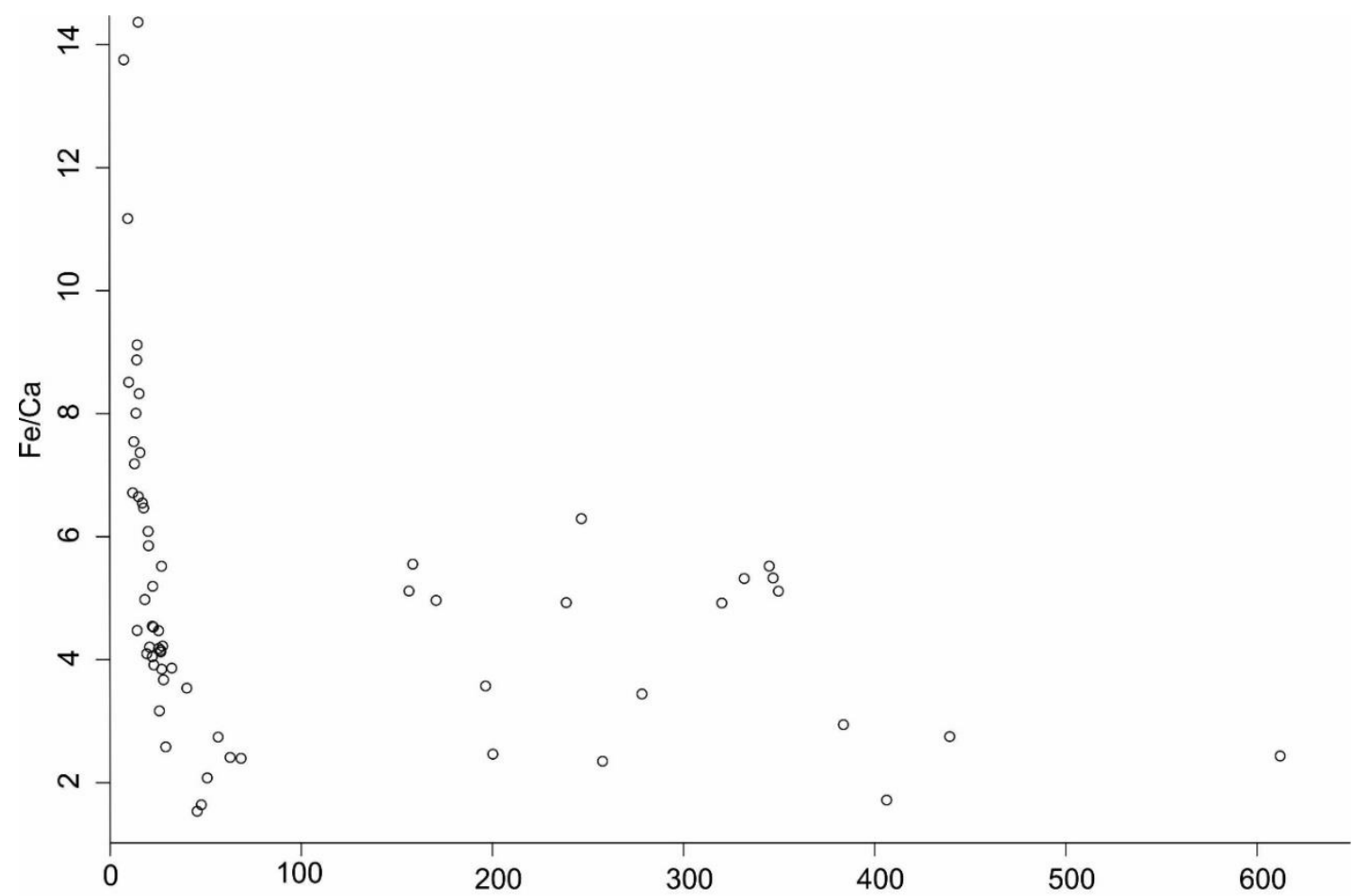

Figure A6 Fe/Ca (ppm) ratio vs mean grain-size $(\mu \mathrm{m})$ for samples measured from DFDP-2A, sampled throughout the entire section drilled.

This finding suggests that in samples with a clay-silt mean grain-size range, $\mathrm{Fe} / \mathrm{Ca}$ ratio is most strongly related to sample grain-size, opposed to sediment provenance. To explore whether a relationship between $\mathrm{Fe} / \mathrm{Ca}$ ratio and sample provenance in silt sized samples, the influence of grain-size on Fe/Ca ratio must be quantified and removed from the data.

A relationship between grain-size and sample chemistry is observed in a number of major element profiles in the DFDP-2 sample set. To examine this a principle components analysis was used, allowing variance in the dataset attributable to grain-size to be quantified. Though rarely greater than 0.3 , a significant portion of variance in the dataset could be related to mean grain-size for elements Fe, Al, Si, K, Ca, Ti and Sr.

In Figure $\mathrm{A} 7, \mathrm{PC} 1$ displays an association between $\mathrm{Al}$ and $\mathrm{K}$ concentrations in samples, and grain-size, with silt samples displaying a comparative enrichment in these elements. PC2 displays an association between Sr concentrations in samples and grain-size, with coarse sand samples displaying a comparative depletion in $\mathrm{Sr}$ concentration, and fine sands to silt displaying minor enrichments. 
Though some outliers exist in the dataset, samples are observed to cluster based on grain-size in Figure A7. The comparable associations observed for elements $\mathrm{Fe}, \mathrm{Ca}, \mathrm{Si}$ and $\mathrm{Ti}$ suggest that sample mineralogy is varying with grain-size, causing the observed changes in element concentrations. Sediment samples were examined using reflected light microscopy, allowing sample mineralogy to be qualitatively analysed.

Observational evidence noted an enrichment of muscovite mica, and minor enrichment in biotite mica in silt samples, with muscovite enrichment increasing with decreasing grain-size.

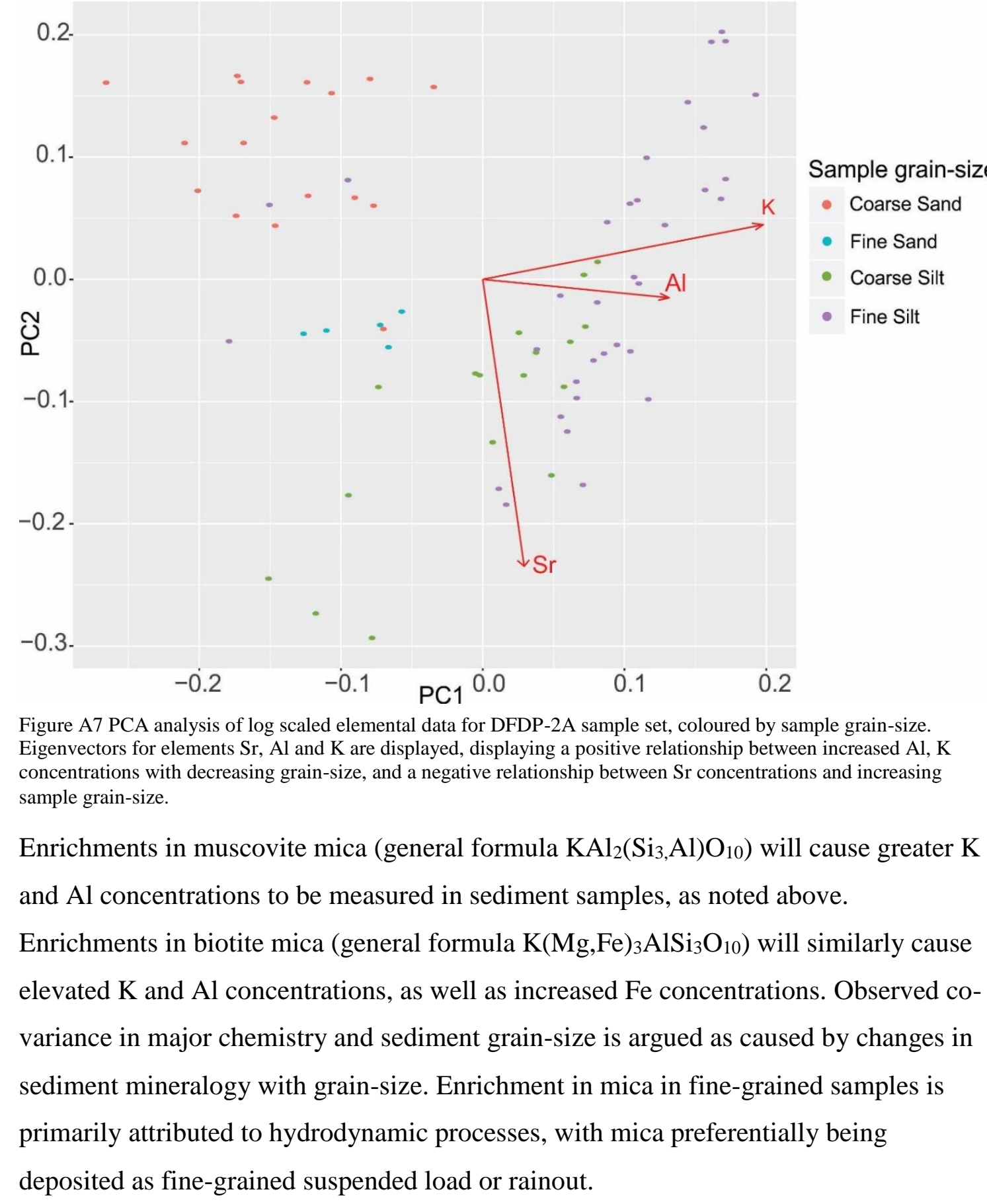


Appendix B2) RA-C40 diagrams developed from clast shape measurements.

RA-C 40 developed from clasts sampled from the laminated siltstone unit, Waitan 6 field site:

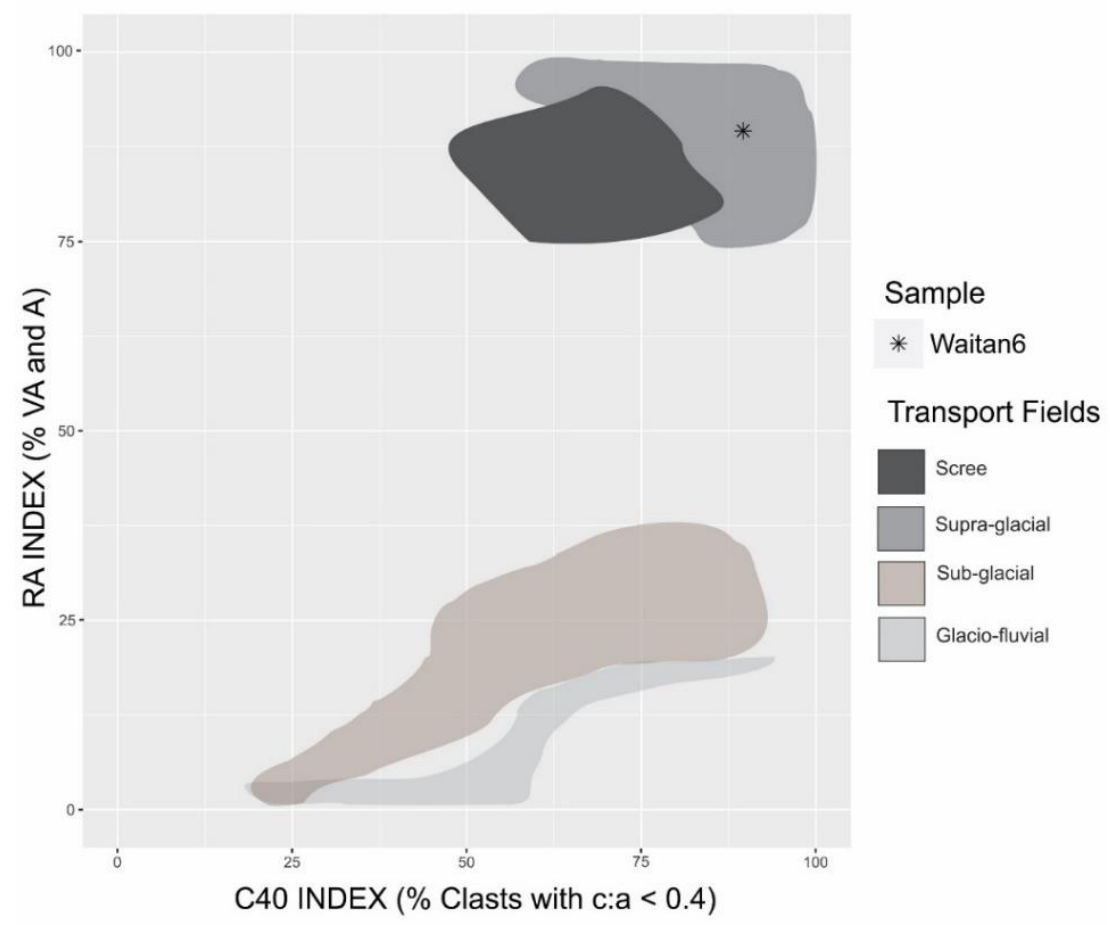

Figure A8 RA-C40 diagram. RA is the percentage of Angular and Very Angular clasts using the scale of Powers (1953), with clasts from Waitan-6 plotted. Transport fields utilise published data of (Benn and Ballantyne, 1993).

RA-C 40 developed for clasts in the sandy siltstone unit at the Cesspool Section:

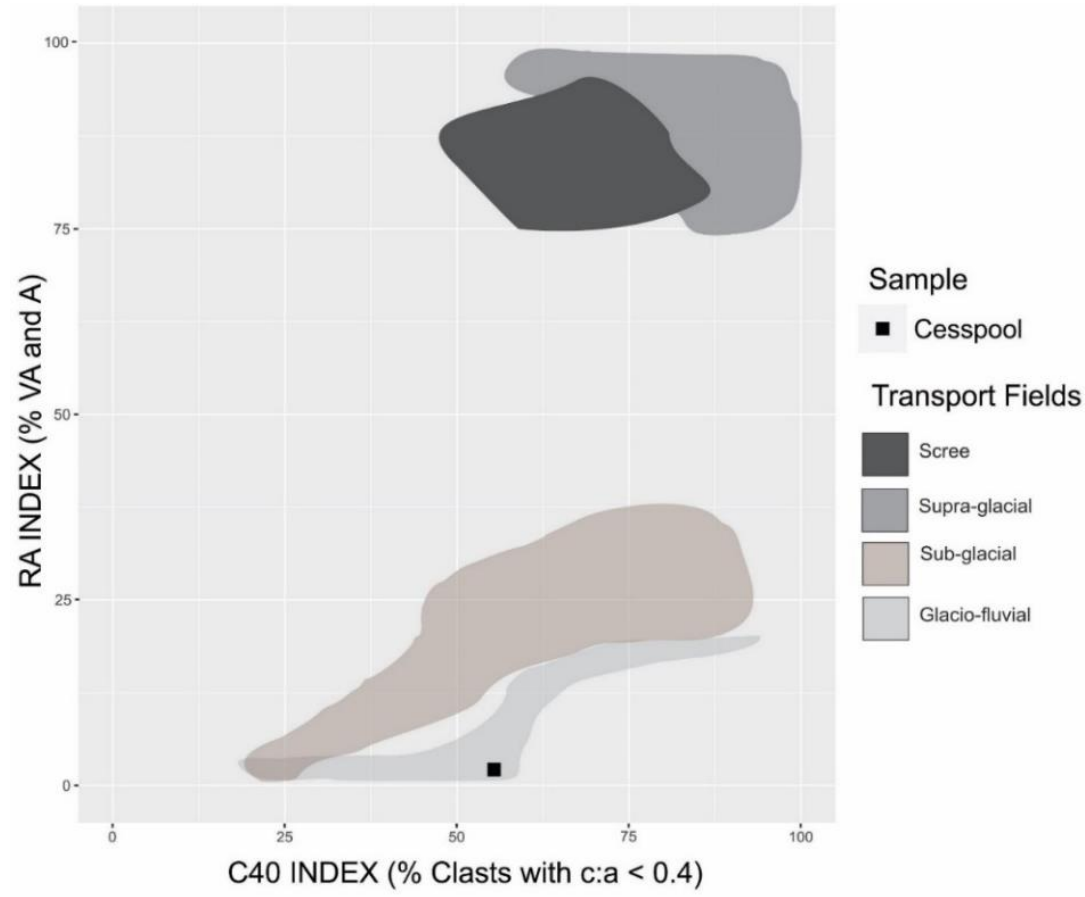

Figure A9 RA-C 40 diagram with clasts from the sandy siltstone plotted. Transport fields utilise published data of (Benn and Ballantyne, 1993). 
RA- $\mathrm{C}_{40}$ developed for clasts in the conglomerate unit at the Arahura Bridge section (Sample A, Sample B):

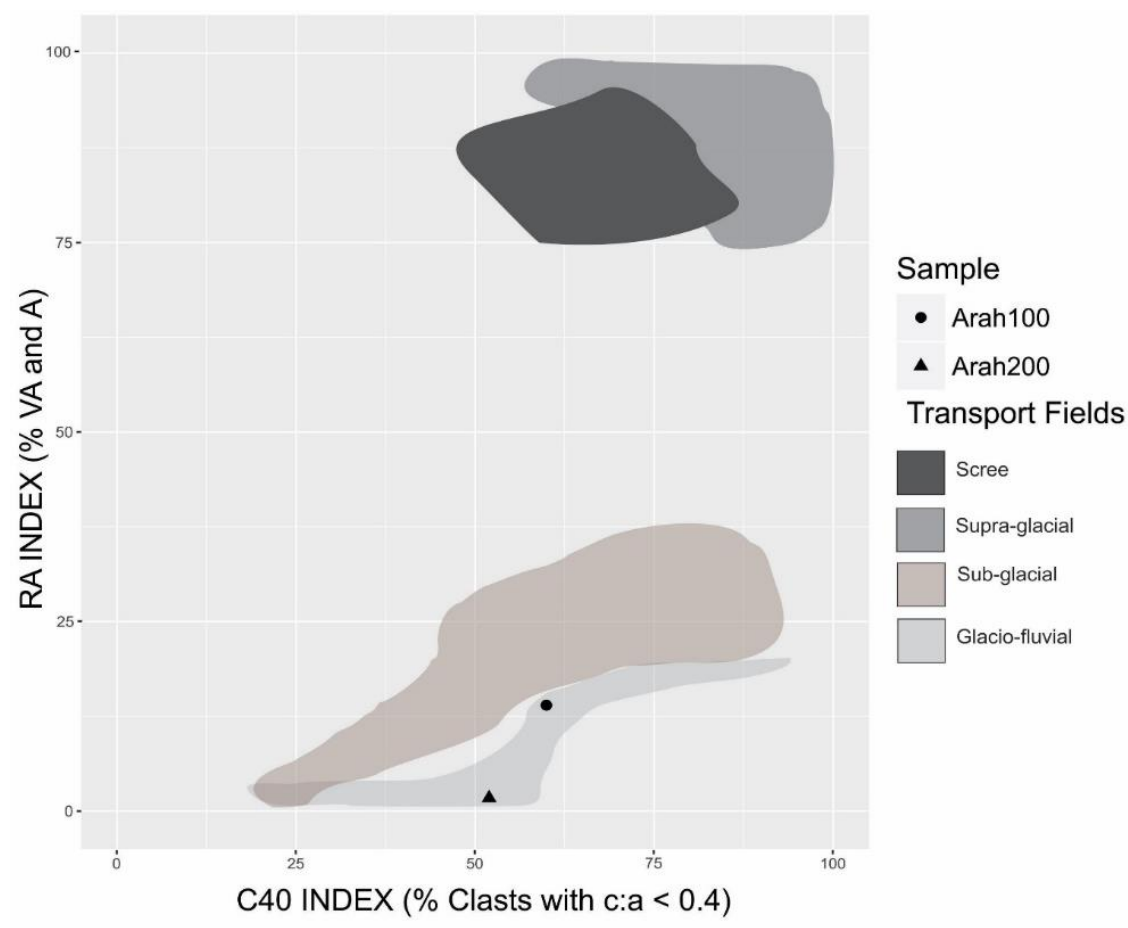

Figure A10 RA-C 40 diagram with clasts from the conglomerate unit plotted. Transport fields utilise published data of (Benn and Ballantyne, 1993).

B3) Additional field site termed Waitan-12, grouped as part of the upper Waitangitaona sections, presented in the format of Section 3.1.1:

\section{Field site Waitan-12:}

The Waitan-12 field site is situated 250 metres upstream of the Waitan-9 field site. This field site was logged in detail as the outcrop could be observed from a three dimensional perspective.

The gross lithology of the unit identified at field site Waitan-12 is a fine sandstone with common clasts (Figure A11). The unit is dominated by metre scale silt to fine sandstone beds, interbedded with $\sim 30$-centimetre matrix supported pebble to cobble conglomerate beds. Due to limited outcrop access, a measured section was not constructed, though the outcrop was photo-logged in detail, in addition to standard field logging. 


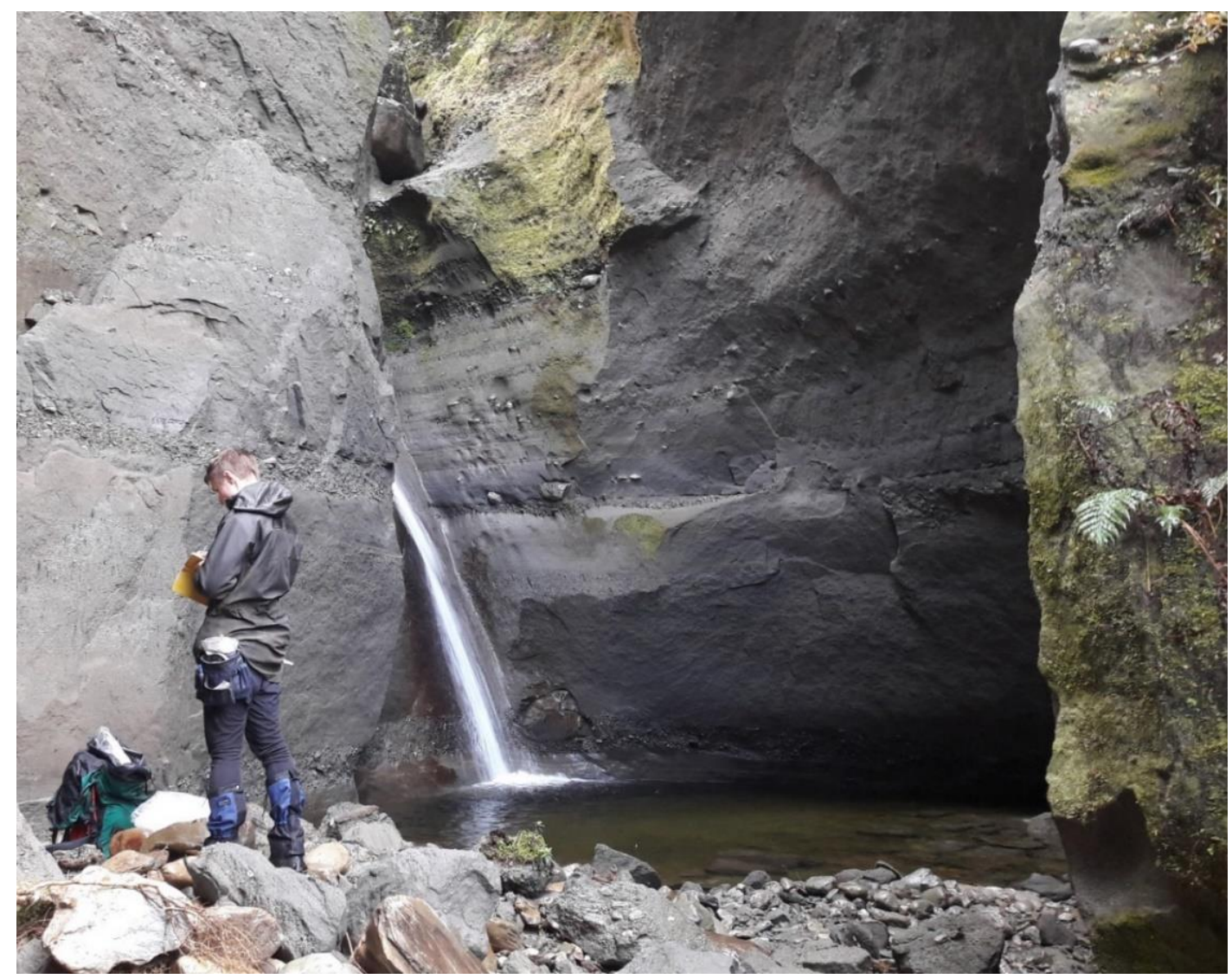

Figure A11: Image of field site Wiatan-12, providing a three dimensional perspective of the fine sandstone unit.

The Waitan-12 unit is overlain by a coarse boulder diamict, which could be observed in nearby slump deposits, however was not accessible in situ. Potentially correlative outcrops are observed upstream of the Waitan-12 field site, though these outcrops were not examined in detail.

\section{Results}

This section will present results from the analysis of the fine sandstone unit exposed at field site Waitan-12.

\section{Grain-size analysis}

A single bulk grain-size sample was analysed from sand beds in the medium-coarse sand unit. Representing the integration of multiple beds, grain-size shows a multimodal, silt dominated distribution, with a minor fine and medium sand component (Figure A12). 


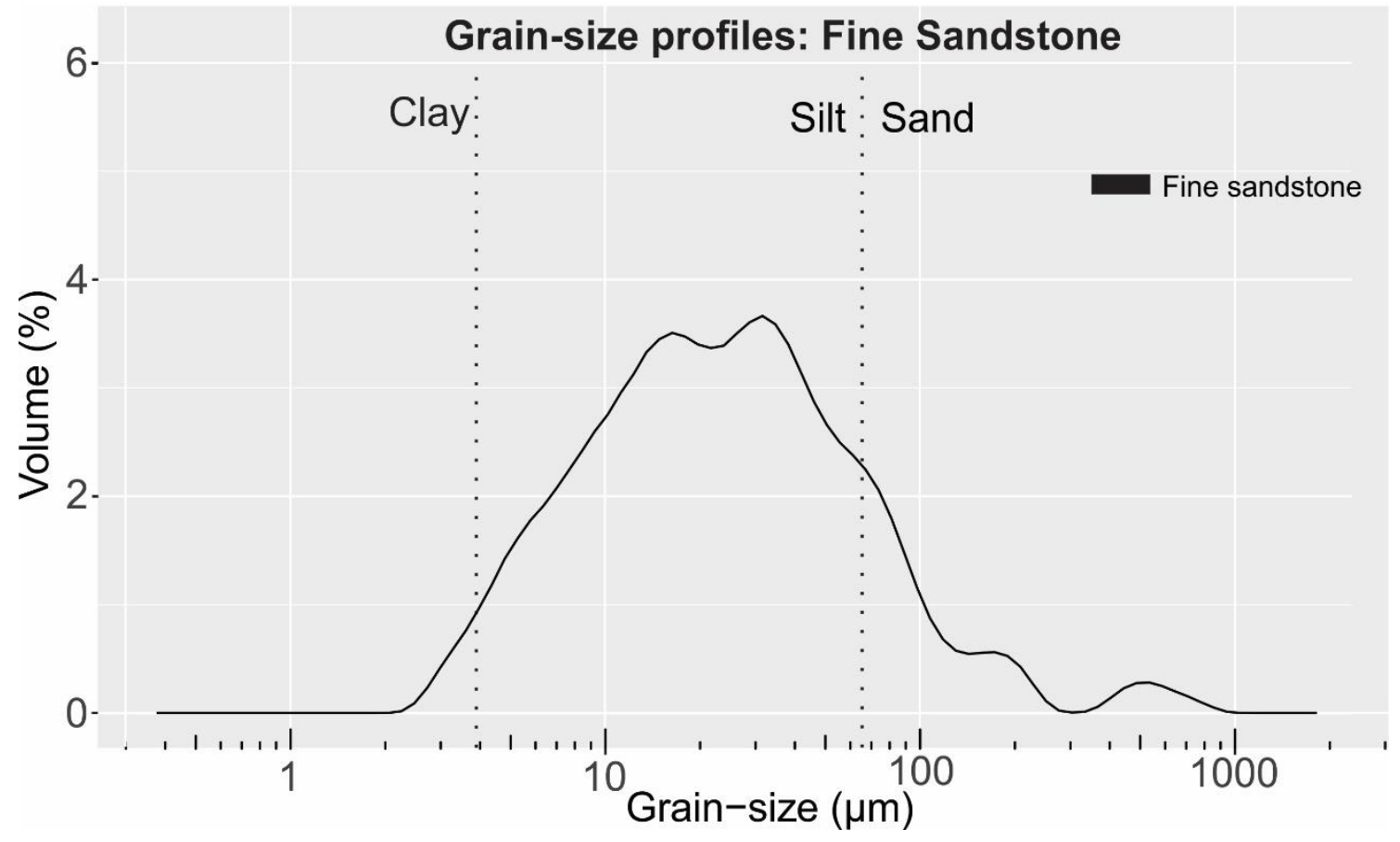

Figure A12 Grain-size profile of bulk sample collected from fine sandstone unit, Waitan-12 field site.

\section{Clast shape}

A bulk sample was collected from a conglomerate bed within the fine sandstone unit, to be analysed using clast shape methods. Clast form analysis (Figure A13) shows clasts in the conglomerate bed assume a variable slab to block morphology, with a mean C/A ratio of 0.48 . Clast lithologies are solely high to medium grade schists, with no clear relationship between lithology and clast shape noted. Krumbein roundness analysis shows clasts assume a broad normal distribution, with a median clast roundness of 0.5 , or sub-rounded.

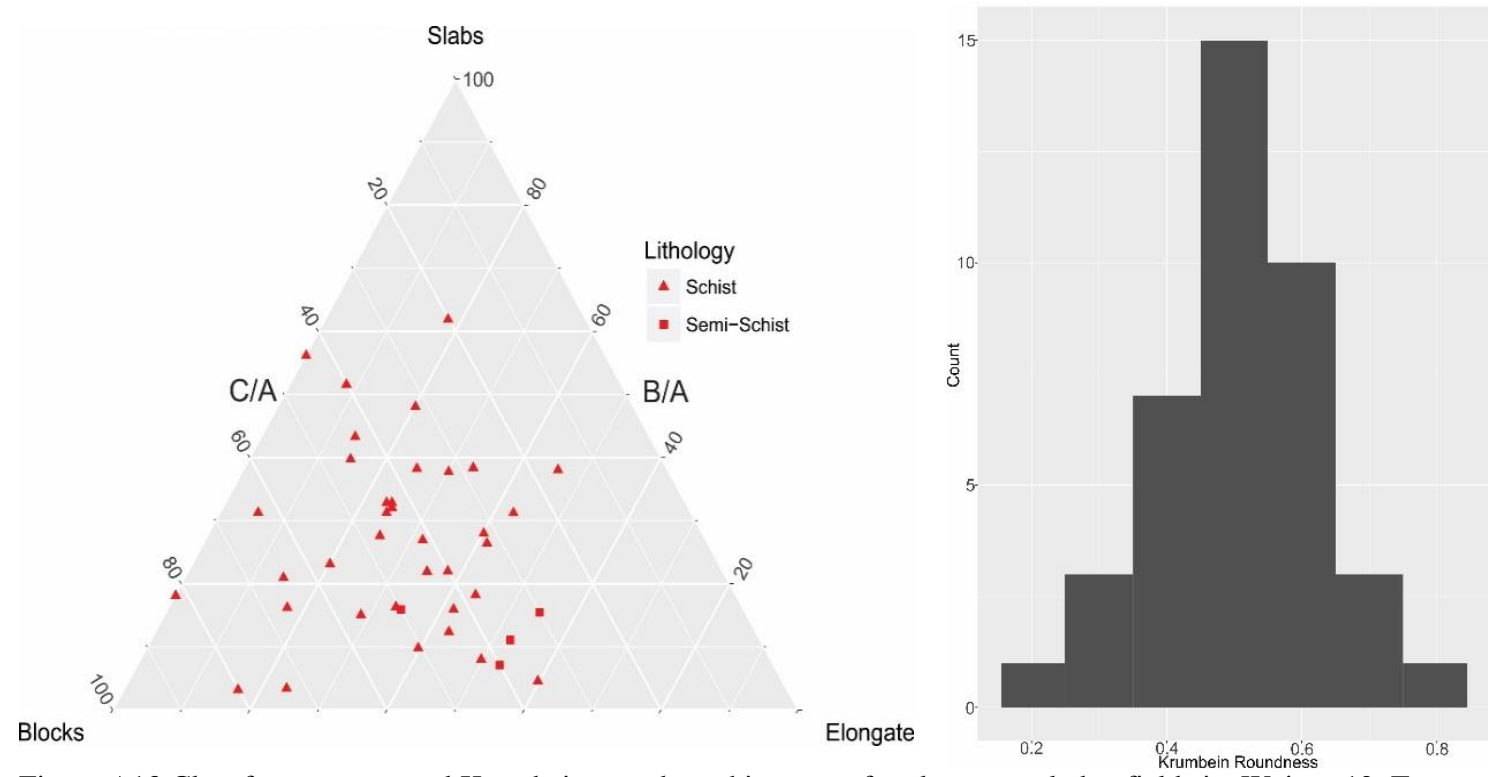

Figure A13 Clast form ternary and Krumbein roundness histogram for clasts sampled at field site Waitan-12. Ternary plot produced based on methods of Benn and Ballantyne (1993). 


\section{Key facies}

Four key facies are identified from the fine sandstone unit at field site Waitan-12, to be used in developing a facies scheme and depositional model (Table A1, Figure A14).

Table A1: Key facies identified at field site Waitan-12. Lithofacies descriptions developed at the Cesspool section remain accurate for units at the Waitan-12 site, with the same facies identified.

\begin{tabular}{|c|c|c|c|c|}
\hline Particle Grade & Facies code & Lithofacies & Bedding/Sedimentary Structures & Facies association \\
\hline \multicolumn{5}{|c|}{ Medium-coarse sand } \\
\hline & $\mathrm{Sl}$ & $\begin{array}{l}\text { Light-dark grey, } \\
\text { med-coarse sands }\end{array}$ & Horizontally laminated, beds $\sim 50 \mathrm{~cm}$ & Overlaying facies $\mathrm{Sr}, \mathrm{Gmh}$ \\
\hline & $\mathrm{Sr}$ & $\begin{array}{l}\text { Light-dark grey, } \\
\text { med-coarse sands } \\
\text { with x bedding }\end{array}$ & Cross bedded, beds $5-50 \mathrm{~cm}$ & $\begin{array}{l}\text { Overlaying facies Sl, commonly } \\
\text { overlain by facies Fmd }\end{array}$ \\
\hline & Slc & $\begin{array}{l}\text { Light-dark grey } \\
\text { medium sands with } \\
\text { clasts }\end{array}$ & $\begin{array}{l}\text { Horizontally laminated, beds } 1-30 \mathrm{~cm} \text {, } \\
\text { sparse pebble-cobble clasts }\end{array}$ & Overlying facies Sl, Slr, Gmh \\
\hline \multicolumn{5}{|l|}{ Gravel } \\
\hline & $\mathrm{Gmh}$ & $\begin{array}{l}\text { Pebble-boulder clasts, } \\
\text { sand matrix }\end{array}$ & $\begin{array}{l}\text { Matrix supported, } \\
20-40 \mathrm{~cm} \text { bed thickness }\end{array}$ & Overlaying Sl, Sr facies \\
\hline
\end{tabular}
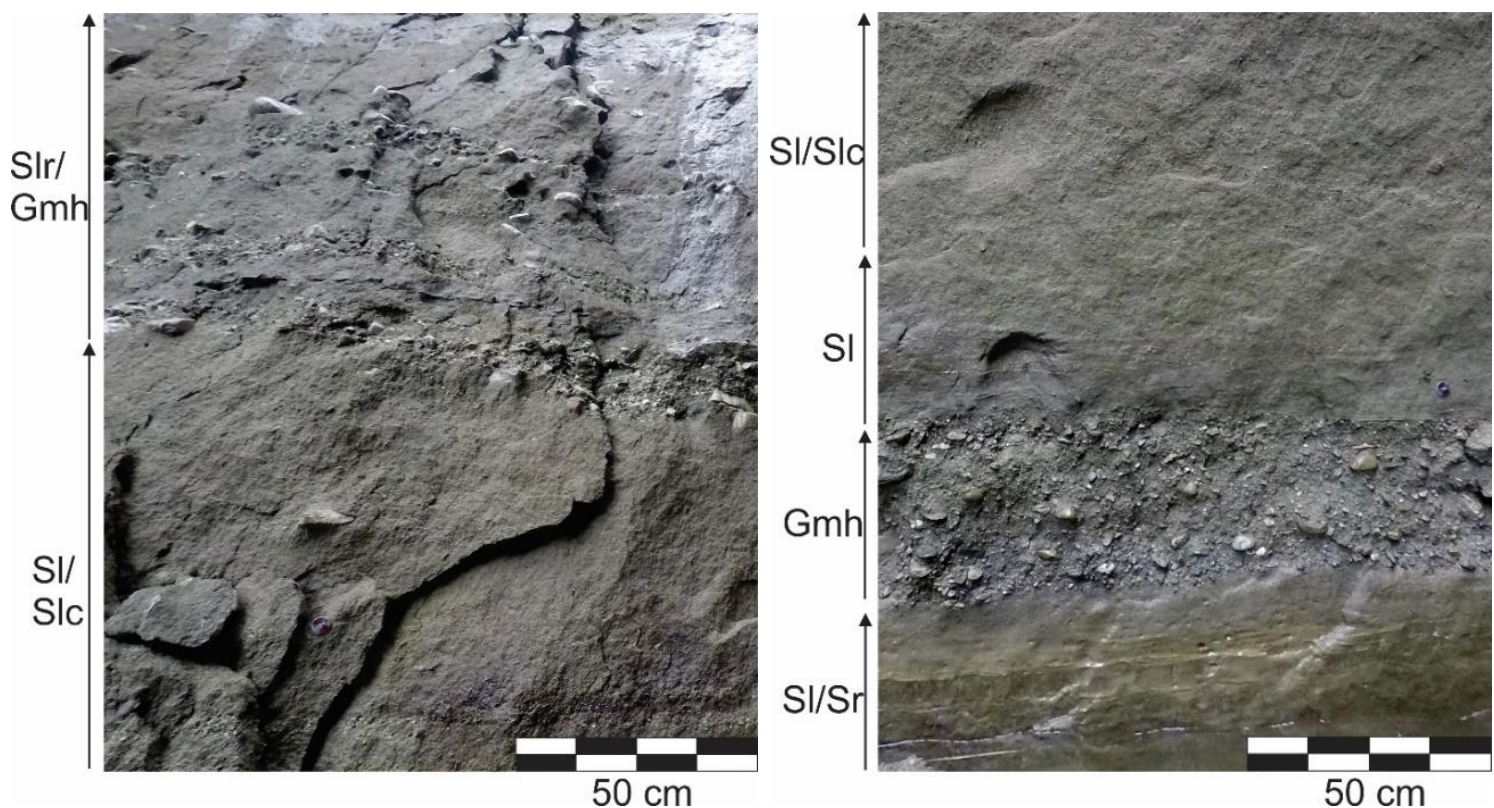

Figure A14: Annotated ortho-photographs with facies identified from the fine sandstone unit at field site Waitan12. 